\title{
Alaska Coal Geology, Resources, and Coalbed Methane Potential
}

By Romeo M. Flores, Gary D. Stricker, and Scott A. Kinney

U.S. Geological Survey, Denver, Colorado 80225

DDS-77

U.S. Department of the Interior

U.S. Geological Survey 


\title{
U.S. Department of the Interior \\ Gale A. Norton, Secretary \\ U.S. Geological Survey \\ Charles G. Groat, Director
}

U.S. Geological Survey, Reston, Virginia: 2004

\author{
For sale by U.S. Geological Survey, Information Services \\ Box 25286, Denver Federal Center \\ Denver, CO 80225 \\ For more information about the USGS and its products: \\ Telephone: 1-888-ASK-USGS \\ World Wide Web: http://www.usgs.gov/
}




\section{Conversion Factors}

\begin{tabular}{|c|c|c|}
\hline Multiply & By & To obtain \\
\hline \multicolumn{3}{|c|}{ Length } \\
\hline inch (in.) & 2.54 & centimeter $(\mathrm{cm})$ \\
\hline inch (in.) & 25.4 & millimeter (mm) \\
\hline foot (ft.) & 0.3048 & meter $(\mathrm{m})$ \\
\hline mile (mi.) & 1.609 & kilometer (km) \\
\hline \multicolumn{3}{|c|}{ Area } \\
\hline acre & 4,047 & square meter $\left(\mathrm{m}^{2}\right)$ \\
\hline acre & 0.4047 & hectare (ha) \\
\hline acre & 0.4047 & square hectometer $\left(\mathrm{hm}^{2}\right)$ \\
\hline acre & 0.004047 & square kilometer $\left(\mathrm{km}^{2}\right)$ \\
\hline square foot $\left(\mathrm{ft}^{2}\right)$ & 9,290 & square centimeter $\left(\mathrm{cm}^{2}\right)$ \\
\hline square foot $\left(\mathrm{ft}^{2}\right)$ & 0.0929 & square meter $\left(\mathrm{m}^{2}\right)$ \\
\hline square inch $\left(\right.$ in $\left.^{2}\right)$ & 6.452 & square centimeter $\left(\mathrm{cm}^{2}\right)$ \\
\hline square mile $\left(\mathrm{mi}^{2}\right)$ & 259.0 & hectare (ha) \\
\hline square mile $\left(\mathrm{mi}^{2}\right)$ & 2.590 & square kilometer $\left(\mathrm{km}^{2}\right)$ \\
\hline \multicolumn{3}{|c|}{ Weight } \\
\hline metric ton & 1.10 & ton, short $(2,000 \mathrm{lb})$ \\
\hline ton, short $(2,000 \mathrm{lb})$ & 0.907 & metric ton \\
\hline pound $(\mathrm{Ib})$ & 453.59 & gram (gm) \\
\hline gram (gm) & 0.0022 & pound $(\mathrm{lb})$ \\
\hline \multicolumn{3}{|c|}{ Energy } \\
\hline Btu per pound (Btu) & 0.0022 & mega joules per kilogram \\
\hline
\end{tabular}

Temperature in degrees Celsius $\left({ }^{\circ} \mathrm{C}\right)$ may be converted to degrees Fahrenheit $\left({ }^{\circ} \mathrm{F}\right)$ as follows:

$$
{ }^{\circ} \mathrm{F}=\left(1.8 \mathrm{x}^{\circ} \mathrm{C}\right)+32
$$

Temperature in degrees Fahrenheit $\left({ }^{\circ} \mathrm{F}\right)$ may be converted to degrees Celsius $\left({ }^{\circ} \mathrm{C}\right)$ as follows:

$$
{ }^{\circ} \mathrm{C}=\left({ }^{\circ} \mathrm{F}-32\right) / 1.8
$$




\section{Contents}

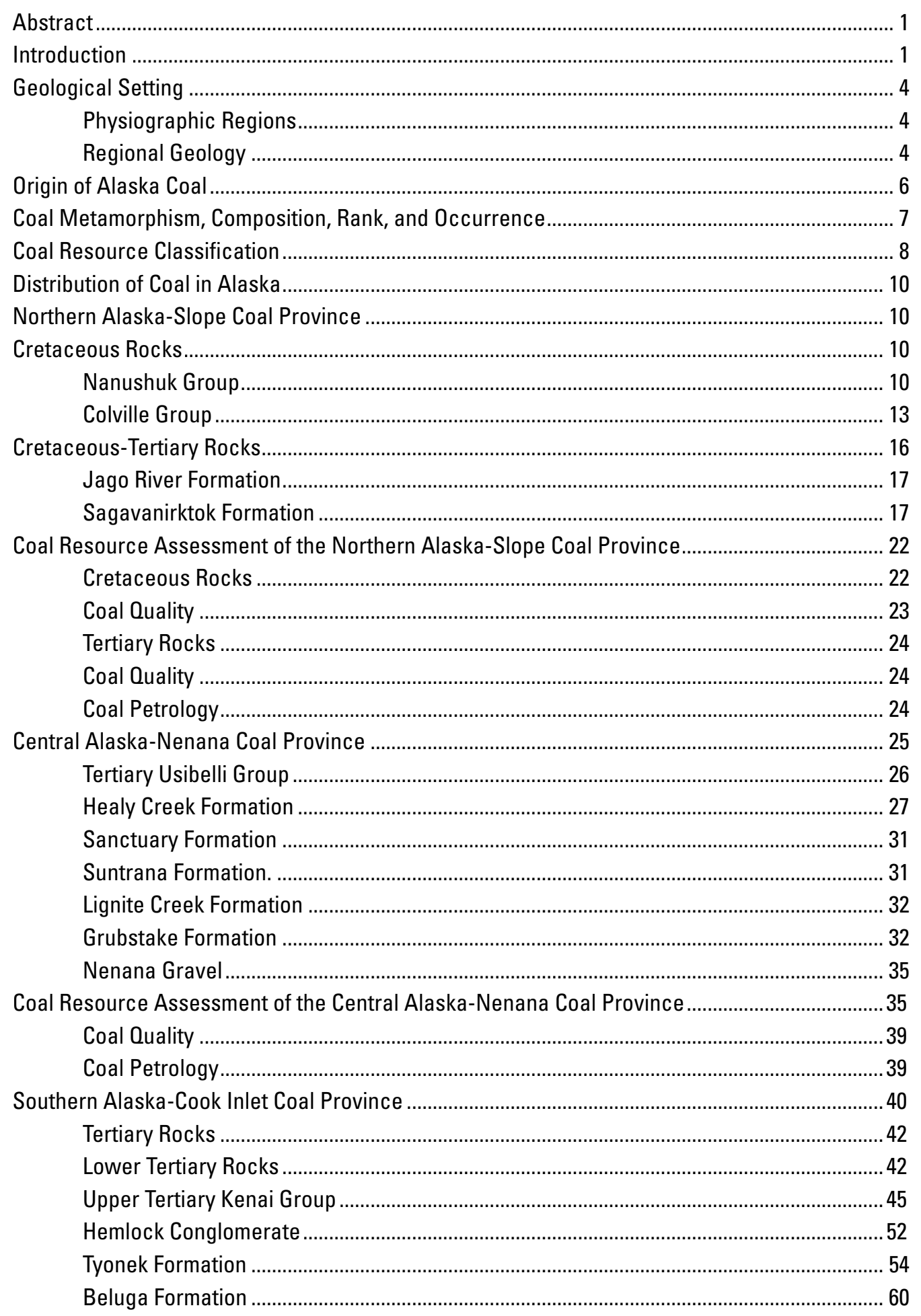




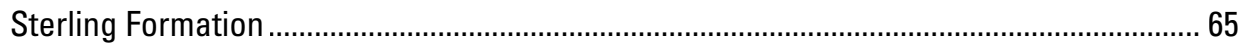

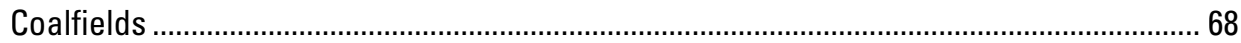

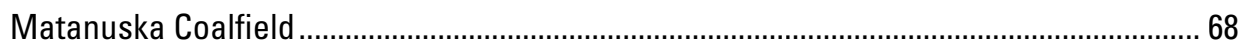

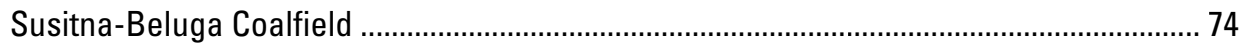

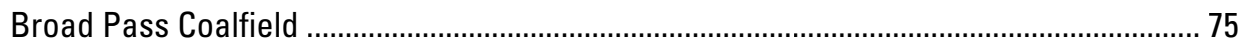

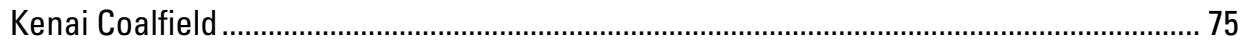

Coal Resource Assessment in the Southern Alaska-Cook Inlet Coal Province .............................. 76

Matanuska Coalfield ................................................................................................ 78

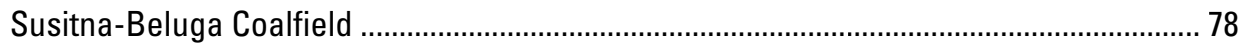

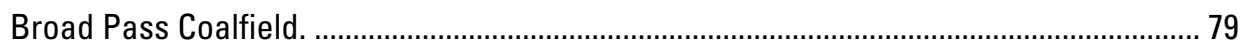

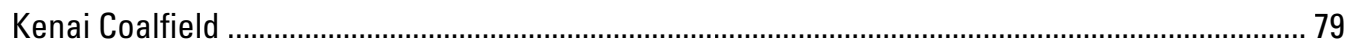

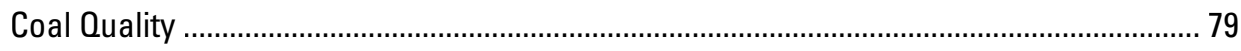

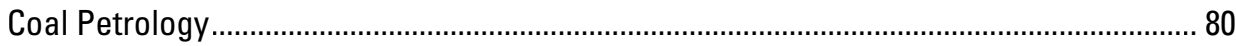

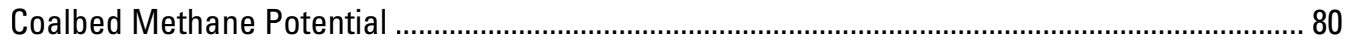

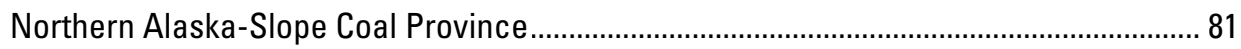

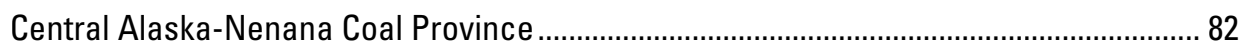

Southern Alaska-Cook Inlet Coal Province.................................................................................... 82

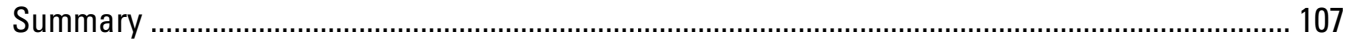

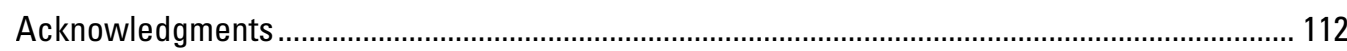

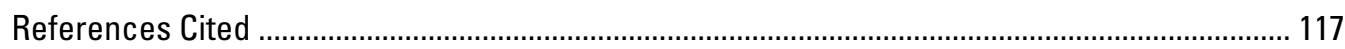

\section{Figures}

1. Map showing coal ranks in coal basins and coal occurrences in Alaska with emphasis on the Northern Alaska-Slope, Central Alaska-Nenana, and Southern Alaska-Cook Inlet

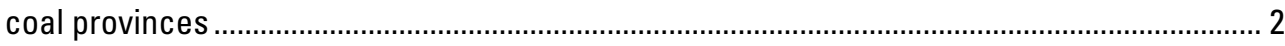

2. Map showing the coal rank and land ownership of Alaska ..................................................... 3

3. Map showing the geology and structure of Alaska .................................................................. 3

4. Map showing the physiographic regions of Alaska .............................................................. 5

5. Map showing general tectonic framework of the Cook Inlet Basin, associated subduction

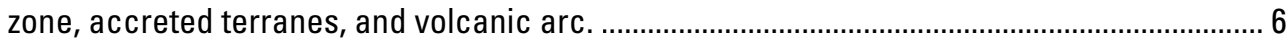

6. Stratigraphic column of the Mesozoic and Cenozoic rocks in the Northern Alaska-

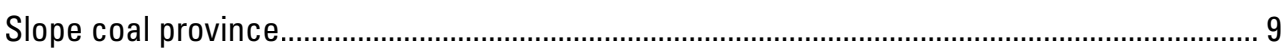

7. Photograph of a coal bed (about 20 feet thick) in the Nanushuk Group .................................. 11

8. Map showing net coal thickness map of the Nanushuk Group in the western part of

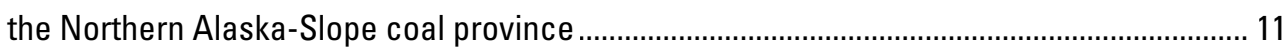

9. Cross section showing the Nanushuk progradation sequences............................................... 12

10. Sandstone percentage contour map in the Northern Alaska-Slope coal province ................. 13

11. Paleogeographic maps showing the depositional environments of the Nanushuk Group in the central Northern Alaska-Slope coal province. (A) early to middle Albian time; (B) middle to late Albian time; (C) late Albian to Cenomanian (?) time; and (D) Cenomanian time (maximum regression). 
12. Photograph of interbedded coal, sandstone, siltstone, and mudstone of the Kogosukruk Tongue of the Prince Creek Formation along the lower Colville River downstream from the mouth of the Anaktuvuk River

13. Paleogeographic map showing the depositional environments of the Jago

River Formation in the Arctic National Wildlife Refuge area 17

14. Photograph of a coal bed underlain by a sandstone in the Sagavanirktok Formation 18

15. Photograph of fluvial-channel sandstone and associated rocks in the Sagavanirktok Formation

16. Stratigraphic cross section of the Tertiary Brookian sequence in the eastern part of the National Petroleum Reserve Alaska.

17. West to east stratigraphic cross section showing variations of the coal beds, conglomerates, sandstones, mudstones, and siltstones in the Staines Tongue of the Sagavanirktok Formation between the National Petroleum Reserve in Alaska and Arctic National Wildlife Refuge 20

18. Maps showing the (A) depth to top of coal-bearing interval and $(B)$ net coal thickness isopach of the Staines Tongue of the Sagavanirktok Formation ............................................... 21

19. Map showing the coalfields in the Central Alaska-Nenana coal province ............................... 25

20. Generalized stratigraphic and lithofacies column of the Usibelli Group in the Central Alaska-Nenana coal province

21. Stratigraphic cross section showing the variations of the conglomerates, sandstones, siltstones, mudstones, and coal beds in the lower part of the Usibelli Group in the Healy Creek coalfield on the southern part of the Central Alaska-Nenana coal province.

22. Paleogeographic maps showing depositional environments of: (A) Healy Creek Formation, (B) Sanctuary Formation, (C) Suntrana Formation, and (D) Lignite Creek Formation

23. Crossbed-orientation measurements in fluvial-channel sandstones in the Healy Creek, Suntrana, and Lignite Creek Formations in Suntrana area

24. Stratigraphic cross section showing the basal conglomerates and sandstones in the lower part of the Healy Creek Formation east of Suntrana

25. Photograph of conglomerates (a few inches to 5 feet thick or a few centimeters to 1.5 meters) and sandstones ( 6 inches to 8 feet thick or 15.2 centimeters to 2.4 meters) deposited by braided streams in the lower part of the Healy Creek Formation in east of Suntrana

26. Stratigraphic cross section showing the middle, coal-bearing part of the Healy Creek Formation east of Suntrana

27. Stratigraphic cross section of the uppermost part of the Healy Creek Formation showing the fluvial-channel sandstones and F coal bed, and overlying Sanctuary Formation east of Suntrana

28. Photograph of the uppermost part of the Healy Creek Formation, $\mathrm{F}$ coal bed, and overlying mudstones of the Sanctuary Formation in the Lignite Creek coalfield

29. Photograph of the lacustrine mudstone and lenticular limestone units in the Sanctuary Formation in the Lignite Creek coalfield. 
30. Stratigraphic cross section of the Suntrana Formation showing the Nos. 2, 3, and 4 coal beds and interbedded fluvial-channel sandstones west of Suntrana

31. Photograph of the Suntrana showing the thick No. 3 coal bed, clinker bed of No. 4 coal bed, thin No. 5 coal bed, and interbedded fluvial-channel sandstones and clay plug-overbank deposits west of Suntrana.

32. Photograph of the abandoned fluvial-channel mudstone or clay plug deposit. 33

33. Stratigraphic cross section of the Nos. 3, 4, and 6 coal beds of the Suntrana Formation in the Poker Flats strip mine of Usibelli Coal Mine

34. Photograph of the Poker Flats strip mine showing the highwall exposing fluvial-channel sandstones and No. 3 coal bed (lower bench) and No. 4 coal bed (upper bench)................... 34

35. Thickness map of the No. 6 coal bed of the Suntrana Formation...

36. Stratigraphic cross section of the lower part of the Lignite Creek Formation showing interbedded fluvial-channel sandstones, crevasse splay flood-plain deposits, and thin coal beds west of Suntrana

37. Photograph of the interbedded fluvial-channel sandstones, flood-plain deposits, and an interbedded thin coal bed of the Lignite Creek Formation west of Suntrana

38. Photograph of the coarsening-upward mudstone, siltstone, and sandstone sequence overlain by thin coal beds of the Lignite Creek Formation west of Suntrana. 36

39. Stratigraphic cross section showing variation of minable Healy Creek coal beds and associated sandstones, mudstones, and siltstones in the Jarvis Creek coalfield ................... 38

40. Map showing coalfields in the Southern Alaska-Cook Inlet coal province.............................. 41

41. Tectonic and volcanic settings of the Cook Inlet Basin ......................................................... 42

42. Generalized time-transgressive stratigraphy in the Cook Inlet Basin ..................................... 43

43. Depositional model of the Kenai Group in the Cook Inlet Basin ............................................. 44

44. Generalized chronostratigraphic column of the coal-bearing Kenai Group and related rock units in the Southern Alaska-Cook Inlet coal province. 44

45. A generalized stratigraphic column of the Chickaloon and Wishbone Formations in the Matanuska coalfield 45

46. Photograph of coal beds of the Chickaloon Formation in the Wishbone Hill coal district...... 46

47. Photograph of the lenticular fluvial-channel sandstone (20 feet or 6.1 meters thick) and associated rocks of the Chickaloon Formation in the Wishbone Hill coal district

48. Photograph of the tabular crevasse splay sandstone and associated flood-plain deposits of the Chickaloon Formation in the Wishbone Hill coal district

49. Vertical and lateral lithofacies variations of the Wishbone Formation in the Wishbone Hill coal district

50. Photograph of the braided-stream-deposited conglomerates and sandstones in the Wishbone Formation in the Wishbone Hill coal district.

51. Stratigraphic cross section of the lower part of the Chickaloon Formation in the Wishbone Hill coal district 
52. Photograph of the lower part of the Chickaloon Formation showing the Midway coal zone and adjoining fluvial-channel sandstones in the Wishbone Hill coal district.

53. Stratigraphic cross section of the middle part of the Chickaloon Formation in the Wishbone Hill coal district

54. Photograph of the upper part of the Chickaloon Formation showing the Premier coal zone (50 feet or 15.2 meters thick), Jonesville coal zone (30 feet or 9.1 meters thick), and associated fine-grained sediments in the Wishbone Hill coal district.

55. Stratigraphic cross section of the upper part of the Chickaloon Formation in the Wishbone Hill coal district 50

56. Photograph of the upper part of the Chickaloon Formation showing the Jonesville coal zone overlain by fluvial-channel sandstones ( $>50$ feet or $>15.2$ meters thick) of the Wishbone Formation in the Wishbone Hill coal district.

57. Paleogeographic map showing depositional environments of the Chickaloon Formation in the Matanuska coalfield

58. Map showing lines of stratigraphic cross sections of the Kenai Group in the offshore and onshore Cook Inlet Basin. Map also shows areas of cross sections the Kenai Group in the Chuitna area, Capps Glacier area, along the west coast of Kenai Peninsula, and along the north coast of Kachemak Bay....

59. Offshore north-south cross section $\left(A-A^{\prime}\right)$ of the Kenai Group along the axis of the Cook Inlet Basin

60. Offshore (west) to onshore (east) cross section $\left(B-B^{\prime}\right)$ of the Kenai Group across the Cook Inlet Basin

61. Onshore north-south cross section ( $\left.C-C^{\prime}\right)$ of the Kenai Group along the western part of the Kenai Peninsula or eastern margin of the Cook Inlet Basin

62. Photograph of conglomerates in the Hemlock Conglomerate in the Katmai National Park... 56

63. Photograph of sandstones in the Hemlock Conglomerate in the Katmai National Park ......... 56

64. Photograph of thin coal and carbonaceous shale beds in the Hemlock Conglomerate in the Katmai National Park

65. Photograph of braided stream deposits (conglomeratic lower part) in the Hemlock Conglomerate 57

66. Net coal thickness isopach map of the Tyonek Formation in the Cook Inlet Basin. 58

67. Photograph of coal beds and interbedded fluvial-channel sandstones and mudstones in the Tyonek Formation in the Chuitna River drainage basin

68. Photograph of fluvial-channel sandstones and Chuitna coal bed in the Tyonek Formation in the Chuitna River drainage basin

69. Net sandstone thickness isopach map of the Tyonek Formation in the Cook Inlet Basin....... 59

70. Paleogeographic map (block diagram) showing depositional environments of the Tyonek Formation in the Cook Inlet Basin

71. Generalized stratigraphic column of minable coal beds in the Tyonek Formation in the Chuitna River drainage basin and adjoining areas. 
72. Three-dimensional cross sections (fence diagram) of the Chuitna coal bed and interbedded erosional-based sandstones deposited by braided streams of the Tyonek Formation in the Chuitna River drainage basin 61

73. Stratigraphic cross section of the coal beds, fluvial-channel sandstones, and intertidal deposits in the Diamond Chuitna lease area east of the Chuitna River drainage basin .......... 61

74. Stratigraphic lithofacies sequence in the Tyonek Formation showing tidal sandstone flats facies near Wasilla.

75. Stratigraphic cross section of the coal beds and fluvial-channel sandstones in the Diamond Chuitna lease area east of the Chuitna River drainage area.

76. Vertical lithofacies and associated geophysical logs of minable coal beds

(Reds 1, 2, and 3, and Blue) and interbedded fluvial-channel sandstones, and flood plain claystones and siltstones in the Diamond Chuitna lease area east of the Chuitna River drainage area...

77. Vertical lithofacies of coal beds (Reds 1,2, and 3) and interbedded tidal and intertidal sandstones, siltstones, and mudstones in the Diamond Chuitna lease area east of the Chuitna River drainage area

78. Photograph of the Capps Glacier coal bed (50 feet or 15.2 meters thick) and overlying fluvial-channel sandstones in the Capps Glacier area...

79. Photograph of the coal beds and interbedded flood-plain/crevasse splay deposits in the Capps Glacier area

80. Structural cross section (north-south) of the Capps Glacier coal bed and associated rocks of the Tyonek Formation in the Capps Glacier area

81. Stratigraphic cross section (northeast-southwest) of the rocks of the Tyonek Formation at Barabara Point showing lenticular conglomerates, sandstone, and coal beds

82. Stratigraphic (structural) cross section of the Capps Glacier coal bed and associated rocks of the Tyonek Formation in the Capps Glacier area.

83. Photograph of the fluvial-channel sandstones (average 60 feet or 18.3 meters thick), flood-plain mudstone and siltstones, and coal beds of the Beluga Formation along the coastal bluffs in west Homer, Kenai Peninsula

84. Photograph of a coal bed (3.5 feet or 1.1 meters thick) and crevasse splay deposits of the Beluga Formation along the coastal bluffs west of Homer, Kenai Peninsula

85. Stratigraphic cross section of the Beluga Formation showing thick coal beds (for example, Cooper coal bed), fluvial-channel sandstones, and flood-plain mudstone and siltstone along the coastal bluffs west of Homer, Kenai Peninsula

86. Stratigraphic cross section of the Beluga Formation showing interbedded thin to thick coal beds (for example, Cooper coal bed), fluvial-channel sandstones, and flood-plain deposits along the coastal bluffs west of Homer, Kenai Peninsula

87. Paleogeographic map (block diagram) showing depositional environments of the Beluga Formation in the Cook Inlet Basin. 68

88. Photograph of fluvial-channel sandstones and thin coal of the Sterling Formation along the coastal bluffs in the Clam Gulch area, Kenai Peninsula.. 
89. Photograph of fluvial-channel sandstones overlying thin ( 3 feet [ 0.9 meter]) to thick (12 feet [3.6 meters]) coal beds of the Sterling Formation along the coastal bluffs between the Clam Gulch and Ninilchik, Kenai Peninsula

90. Stratigraphic cross sections showing variations in fluvial-channel architecture in the upper part of the Sterling Formation in the Clam Gulch area, Kenai Peninsula: A, Lower part of Clamgulchian type section; B, Middle part of Clamgulchian type section; C, Upper part of Clamgulchian type section

91. Stratigraphic cross section showing coal beds, fluvial-channel sandstones, and interbedded flood-plain mudstones and siltstones in the lower part of the Sterling Formation between the Clam Gulch area and Ninilchik, Kenai Peninsula 71

92. Photograph of thin to thick coal beds in the lower part of the Sterling Formation. 72

93. Block diagram showing depositional environments of the Sterling Formation in the Cook Inlet Basin . 72

94. Map showing the geology and coal districts in the Matanuska coalfield 73

95. Cross section of the Premier and Jonesville coal zones of the Chickaloon Formation in the Wishbone Hill coal district

96. Geologic map of the Wishbone Hill coal district showing doubly plunging syncline disrupted by normal faults 74

97. Photograph of a 4-foot-thick (1.2 meters) coal bed interbedded with fluvial-channel sandstones and flood plain mudstones and siltstones in the Sterling Formation in the Clam Gulch area.

98. Stratigraphic cross section showing interbedded coal beds, fluvial-channel sandstones, and flood-plain mudstones and siltstones in the lowermost part of the Sterling Formation along the north shore of Kachemak Bay east and west of McNeil Canyon.

99. Photograph of a coal bed with tonstein partings and related rocks of the Beluga

Formation along the beach bluffs on the northern shore of the Kachemak Bay 76

100. Stratigraphic cross section showing interbedded coal beds, fluvial-channel sandstones, and flood-plain mudstones and siltstones in the uppermost part of the Beluga Formation west of McNeil Canyon

101. Stratigraphic cross section showing interbedded coal beds, fluvial-channel sandstones, and flood-plain mudstones and siltstones in the uppermost part of the Beluga Formation at the mouth of Fritz Creek.

102. Distribution of surface vitrinite reflectance values at sea level in the Northern Alaska-Slope coal province

103. Map of the Northern Alaska-Slope coal province showing distribution of bituminous and subbituminous coals

104. Map showing surface vitrinite reflectance values in the Northern Alaska-Slope, Central Alaska-Nenana, and Southern Alaska-Cook Inlet coal provinces

105. Vitrinite reflectance values for the Meade Quadrangle, National Petroleum Reserve in Alaska 106

106. Vitrinite reflectance values for the Tunalik No. 1 well, National Petroleum Reserve in Alaska 
107. Stratigraphic cross section of the Nanushuk Group with superimposed vitrinite reflectance values. 108

108. Coalbed methane potential in the Nanushuk Group coals based on the thickness and vitrinite reflectance of the nonmarine part of the group in the Northern Alaska-Slope coal province

109. Distribution of surface vitrinite reflectance $\left(R_{0}\right)$ values in the Northern Alaska-Slope coal province

110. Map of the Cook Inlet Basin showing distribution of oil and gas fields offshore and onshore.

111. Facies profile of the lower part of the Sterling Formation and accompanying downhole logs showing horizons of gas accumulation.

112. Facies profile of the upper part of the Beluga Formation and accompanying downhole logs showing horizons of gas-perforated intervals

113. Location map of the Kenai gas field in the Kenai Peninsula. 112

114. Basinwide and vertical variations of vitrinite reflectance $\left(R_{0}\right)$ values in the Cook Inlet Basin

115. Coalbed methane prospect area and depths to vitrinite reflectance values of 0.6 percent superimposed on the thickness isopach of the Tyonek Formation south of the Castle Mountain fault in the northeastern part of the Cook Inlet

116. Downhole geophysical logs, hot wire total gas and methane contents, vitrinite reflectance values, and illite diagenetic values in the Edna Mae Walker drill hole

117. Stratigraphic cross section of the Kenai Group in the offshore Cook Inlet Basin with superimposed vitrinite reflectance values

118. Stratigraphic cross section of the Kenai Group in the onshore Cook Inlet Basin with superimposed vitrinite reflectance values

\section{Tables}

1. Coal resource estimates for Alaska using the classification system of Wood and others (1983)........ 8

2. Estimates of hypothetical coal resources for the Cretaceous Nanushuk Group and Tertiary Staines Tongue in the Sagavanirktok Formation in the Northern Alaska-Slope coal province ......... 23

3. (a) Coal quality of coal deposits in the Cretaceous Nanushuk Group in the Northern Alaska-Slope coal province. (b) Coal quality of coal deposits in the Tertiary Staines Tongue in the Sagavanirktok Formation in the Northern Alaska-Slope coal province 24

4. Estimates of coal resources for the Tertiary Usibelli Group in the Central Alaska-Nenana coal province 37

5. Coal quality of coal deposits in the Tertiary Usibelli Group in the Central Alaska-Nenana coal province. 
6. Estimates of coal resources for the Tertiary Kenai Group in the Matanuska, Broad Pass, Susitna, and Kenai coalfields in the Southern Alaska-Cook Inlet coal province 78

7. Range (minimum and maximum values) of quality parameters for Tertiary coal deposits in the Matanuska, Broad Pass, Susitna, and Kenai coalfields in the Southern Alaska-Cook Inlet coal province.

8. (a) Vitrinite reflectance values of coals across the surface in the Northern Alaska-Slope, Central Alaska-Nenana, and Southern Alaska-Cook Inlet coal provinces. (b) Vitrinite reflectance values of coals across the surface in the Northern Alaska Slope, Central-Alaska-Nenana, and Southern Alaska-Cook Inlet coal provinces (a) 85 , (b) 102

9. Properties of sandstone reservoirs and associated gas in the Sterling and Beluga Formations 110 


\title{
Alaska Coal Geology, Resources, and Coalbed Methane Potential
}

\author{
By Romeo M. Flores, Gary D. Stricker, and Scott A. Kinney
}

\section{Abstract}

Estimated Alaska coal resources are largely in Cretaceous and Tertiary rocks distributed in three major provinces. Northern Alaska-Slope, Central Alaska-Nenana, and Southern Alaska-Cook Inlet. Cretaceous resources, predominantly bituminous coal and lignite, are in the Northern Alaska-Slope coal province. Most of the Tertiary resources, mainly lignite to subbituminous coal with minor amounts of bituminous and semianthracite coals, are in the other two provinces. The combined measured, indicated, inferred, and hypothetical coal resources in the three areas are estimated to be 5,526 billion short tons (5,012 billion metric tons), which constitutes about 87 percent of Alaska's coal and surpasses the total coal resources of the conterminous United States by 40 percent.

Coal mining has been intermittent in the Central AlaskanNenana and Southern Alaska-Cook Inlet coal provinces, with only a small fraction of the identified coal resource having been produced from some dozen underground and strip mines in these two provinces. Alaskan coal resources have a lower sulfur content (averaging 0.3 percent) than most coals in the conterminous United States and are within or below the minimum sulfur value mandated by the 1990 Clean Air Act amendments. The identified resources are near existing and planned infrastructure to promote development, transportation, and marketing of this low-sulfur coal. The relatively short distances to countries in the west Pacific Rim make them more exportable to these countries than to the lower 48 States of the United States.

Another untapped but potential resource of large magnitude is coalbed methane, which has been estimated to total 1,000 trillion cubic feet ( 28 trillion cubic meters) by T.N. Smith, 1995, Coalbed methane potential for Alaska and drilling results for the upper Cook Inlet Basin: Intergas, May $15-19,1995$, Tuscaloosa, University of Alabama, p. $1-21$.

\section{Introduction}

This report is a synthesis of the largely untapped hypothetical coal resources of Alaska, which are estimated to be as much as 5,526 billion short (or 5.5 trillion) tons $(5,012$ billion metric tons). The last coal resource assessment in 1974 for the conterminous United States (coal remaining in the ground) estimated a total coal resource of 3,968 billion short tons (3,600 billion metric tons) or 4 trillion short tons (Averitt, 1975). Thus, the Alaska coal resource estimate surpasses the total coal resources of the conterminous United States by 40 percent. This report focuses on an assessment of the coal resources of the three major coal provinces in Alaska: Northern Alaska-Slope, Central Alaska-Nenana, and Southern Alaska-Cook Inlet and makes up 87 percent of the total coal resources of the State (fig. 1). Also, it will concentrate on the origin, geologic setting, and depositional environments of the coal, as well as coal rank, quality, and petrology and the amount of the resources. In addition, this report will summarize the coalbed methane potential and prioritize areas for exploration and development in these major coal provinces.

The coal resources of Alaska occur in discrete areas (coalfields) and in isolated, unrelated outcrops (occurrences) (fig. 1). A coalfield may contain coal beds of various ranks, shown in figure 2 , and different ages and geologic settings, shown in figure 3. Coal resources and geological settings of minor coalfields not reported here may be found in Stricker (1991) and Wahrhaftig and others (1994).

Before the arrival of the European immigrants, native inhabitants used coal in Alaska (Chapman and Sable, 1960, p. 159). The Beechey expedition of 1826-1827 reported the presence of coal in Alaska (Huish, 1836; Dall, 1896). Whaling shippers mined coal from near Cape Beaufort, north of the Arctic Circle, before the turn of the twentieth century (Conwell and Triplehorn, 1976). The first coal mine was opened 


\section{Alaska Coal Geology, Resources, and Coalbed Methane Potential}

in 1855 and closed in 1867 at Port Graham (fig. 2) on the southwestern part of the Kenai Peninsula (Martin, 1915). The Russians opened and operated this coal mine before the United States took possession of the Alaska Territory. The U.S. Congress passed two significant legislative acts in 1914 that led to development of coal resources of Alaska: (1) the Alaska Coal Leasing Act promoted opening mines in the Alaskan coalfields and (2) the Alaska Railroad Enabling Act authorized construction of the railroad from Anchorage to Fairbanks, which encouraged the use of coal by the locomotives and by the gold mining operations to power gold dredges and to fuel steam boilers for thawing the frozen ground.

Many coal mines in the Nenana and Matanuska coalfields were active after Congress authorized the construction of the Alaska Railroad, which promoted large-scale production, transportation, and marketing. The first coal-lease sale was held in conjunction with an oil-lease sale in 1983. In 1984, export of Alaskan coal began with shipments to South Korea from Nenana coalfield. Other developments included con- struction of a coal terminal at the deep-water port at Seward, new loading facilities at the Usibelli coal mine, and upgrading of the Alaska Railroad to handle hauling coal to Seward. In 1985 , coal production increased by 60 percent over 1984, with a gross value on production of $1.4 \times 10^{6}$ short tons $\left(1.27 \times 10^{6}\right.$ metric tons) valued at $\$ 39.7$ million (Bundtzen and others, 1986). Coal production for the year 2000 was estimated by Szumigala and Swainbank (2001) at 1,473,000 short tons valued at $\$ 38.7$ million with 708,000 short tons being exported to Korea. An estimate of total coal in place is $10.4 \times 10^{12}$ short tons $\left(9.4 \times 10^{12}\right.$ metric tons $)$, or about 50 percent of total of conterminous U.S. resources.

The coal resources of Alaska, have been only minimally exploited or developed. Mined coal is presently utilized for domestic electric power-generating plants, and approximately one-half of the production from the Usibelli mine is shipped to Korea and potentially to other countries bordering the western Pacific Rim.

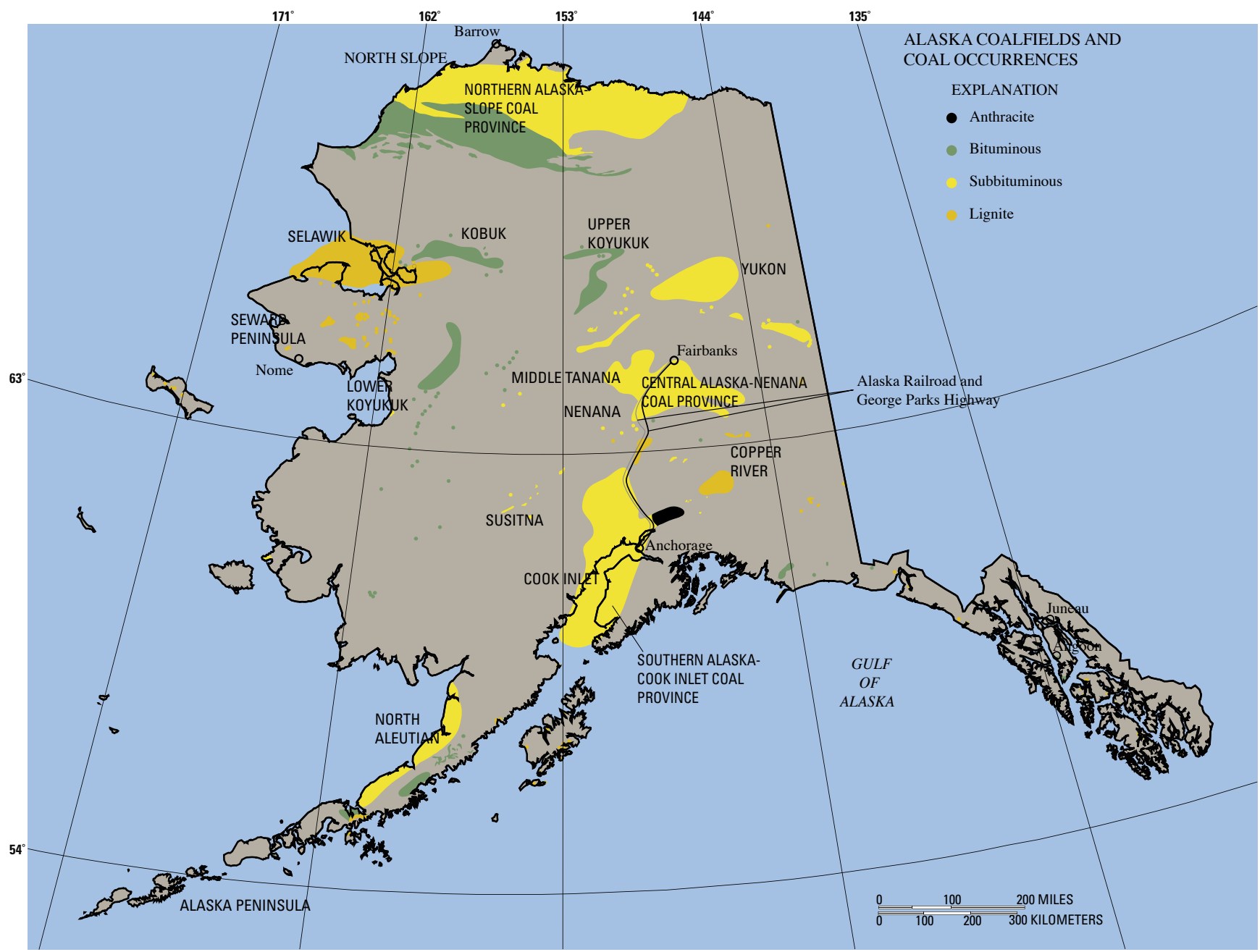

Figure 1. Coal ranks in coal basins and coal occurrences in Alaska with emphasis on the Northern Alaska-Slope, Central Alaska-Nenana, and Southern Alaska-Cook Inlet coal provinces. Compiled and modified from Merritt and Hawley (1986); Barnes (1967a, 1967b); Magoon and others (1976); Plafker (1987). 


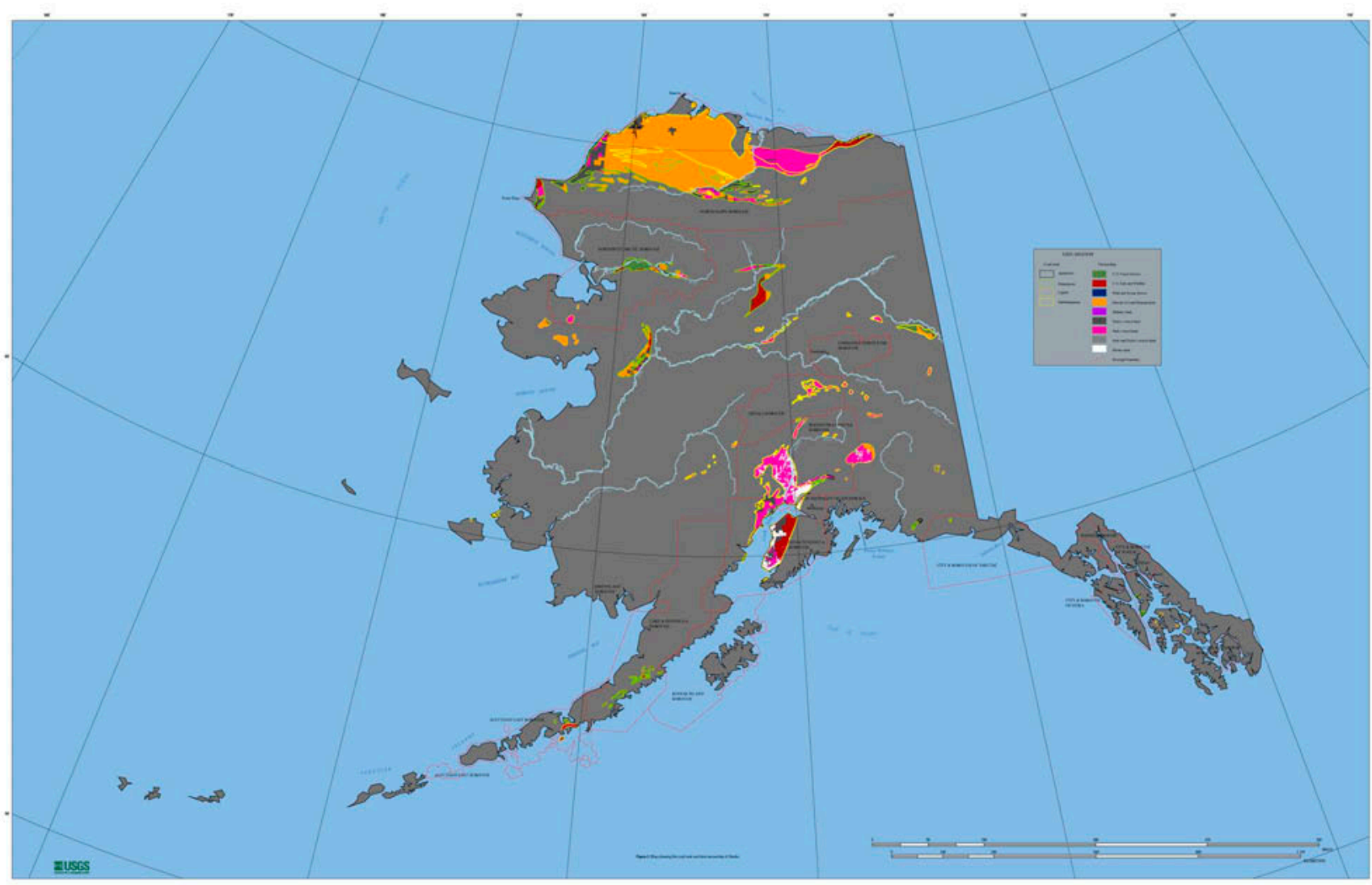

Figure 2. Map showing the coal rank and land ownership of Alaska
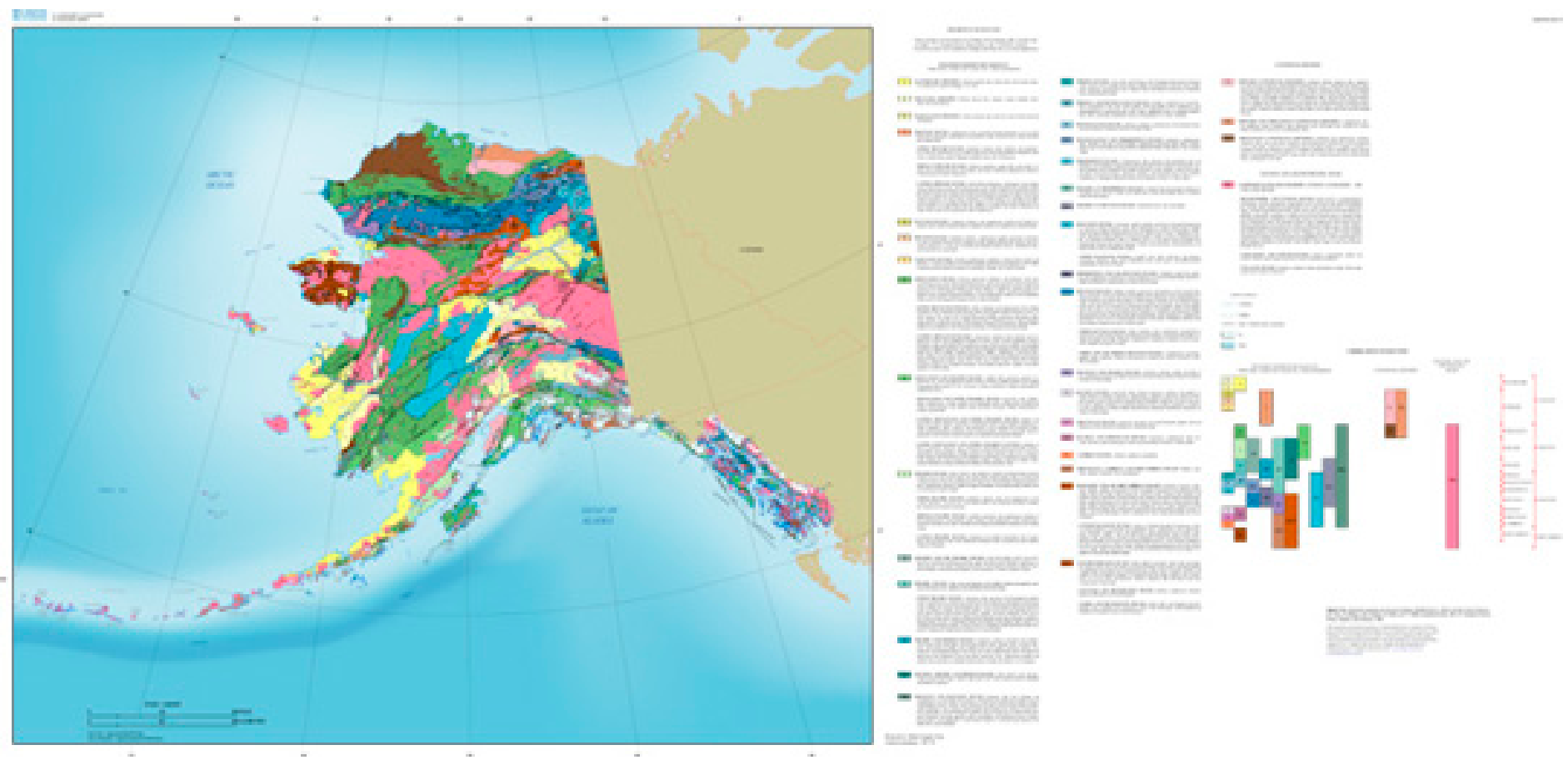

Figure 3. Map showing the geology and structure of Alaska. Modified from S.J. Moll, Scott Bie, Devon Peterson, D.C. Pray, F.H. Wilson, J.M. Schmidt, J.R. Riehle, T.P. Miller (unpublished data, 1997, U.S. Geological Survey, Reston, Virginia) after Beikman (1980). 


\section{Alaska Coal Geology, Resources, and Coalbed Methane Potential}

\section{Geological Setting}

The geology of Alaska (fig. 3; Beikman, 1980) is best described by Plafker and Berg (1994) and by various authors in the 1994 Geology of Alaska volume of The Geological Society of America edited by George Plafker and H.C. Berg. These workers have discussed in detail the physiographic, geologic, tectonic, and volcanic evolution of Alaska from the Proterozoic to the present. Thus, this report describes only those physiographic and geologic settings of Alaska that are critical for understanding the coal-bearing rocks that were investigated in this study.

\section{Physiographic Regions}

Alaska is divided into four physiographic regions (fig. 4); from north to south, they are (1) arctic coastal plain, (2) northern Cordillera, (3) interior or intermountain plateau, and (4) southern Cordillera (Plafker and Berg, 1994; Wahrhaftig and others, 1994).

The arctic coastal plain region extends from the margin of the Arctic Ocean on the north to the northern margin of the Arctic Foothills Range on the south and consists mainly of Tertiary alluvial deposits. Paleozoic, Mesozoic, and Cenozoic rocks underlie the alluvial deposits. The major coal deposits are in the Cretaceous Nanushuk and Colville Groups and Tertiary Sagavanirktok Formation in this region (Wahrhaftig and others, 1994); minor coals occur in the Lower Mississippian Kekiktuk Conglomerate of the Endicott Group (see fig. 3; Tailleur, 1965; Conwell and Triplehorn, 1976; Sable and Stricker, 1987; Wahrhaftig and others, 1994).

The northern Cordillera region is dominated by the east-west-trending Brooks Range (see figs. 3 and 4; Plafker and Berg, 1994). During the Pleistocene, ice caps carved the glacial topography of these mountains. Mainly Cretaceous coal-bearing Nanushuk and Colville Groups underlie the Arctic Foothills Range (see fig. 4). The Paleozoic rocks are mainly exposed in the mountains.

The interior or intermountain plateau is between the Brooks Range on the north and the Alaska Range on the south (see figs. 3 and 4; Plafker and Berg, 1994). This region is part of the intermountain plateau that extends into Canada and the conterminous United States (Great Basin and Colorado Plateaus). Quaternary alluvial deposits sporadically cover the region from the Bering Sea to the Yukon Flats (fig. 3). Elsewhere the interior region is composed of plateaus, hills, and uplands, with numerous domes, ridges, and mountains at the higher elevations (Plafker and Berg, 1994). The interior region was generally free of ice during the Pleistocene glaciation. Beneath the loess and vegetation, the interior region contains pre-Cretaceous basement rocks that include displaced and rotated lithotectonic terranes of Proterozoic and Paleozoic age of miogeocline affinity (Plafker and Berg, 1994). The basement rocks also contain Devonian-Lower Jurassic terranes of oceanic affinity and Jurassic-Lower Cretaceous intraoceanic arc terranes. Mid-Cretaceous and younger plutonic and related rocks, flysch basins, and basalts conceal these rocks. Tertiary coal-bearing rocks are mainly present in several synclinal basins in the northern foothills of the Alaska Range (fig. 3) and are partly or wholly detached from each other by erosion of coal-bearing rocks from intervening structural highs (Wahrhaftig and others, 1994).

The southern Cordillera region is the northernmost extent of the Pacific Mountain system of North America that rims the Pacific Ocean margin (Plafker and Berg, 1994). The region extends from the Alaska Range on the north to the margin of the Gulf of Alaska on the south (fig. 3). It extends westward to the Aleutian Range and Aleutian Islands, which are a continuation of the Alaska Range (fig. 3). Widespread mountain glaciers and ice fields occur in the mountainous parts of the southern Cordillera region (fig. 3). Glaciers currently extend into tidewaters at numerous bays and fiords (Plafker and Berg, 1994). The southern Cordillera region is underlain by Proterozoic to Cenozoic accreted intraoceanic arc and plateau terranes, arc-related accretionary prisms, and flysch basins (Plafker and Berg, 1994). These terranes were intruded by mid-Cretaceous to Paleogene postaccretion plutons, which are, in turn, overlapped by Upper Cretaceous-Tertiary basinal and volcanic rocks. The Tertiary coal-bearing rocks in this region are mainly found in these basins as typified by the Cook Inlet Basin (fig. 3).

\section{Regional Geology}

Alaska is composed mainly of three crustal rock types: (1) continental crust of the Cordillera miogeocline; (2) amalgamated magmatic arcs, oceanic plateaus, melange, and flysch; and (3) oceanic (including ophiolite) rocks (Plafker and Berg, 1994). These crustal rocks were modified by magmatism and metamorphism, overlapped by Cretaceous and Cenozoic rocks, and affected by Cretaceous and Cenozoic faulting and rotation. These tectonic processes produced the structural trends as expressed by the physiographic features of Alaska (fig. 3).

The northern and eastern parts of Alaska were formed by intermittent rifting from the Proterozoic ( $850 \mathrm{Ma}$ ) to the early Paleozoic (Plafker and Berg, 1994). This event was followed by subsidence of the continental margin and deposition of the Proterozoic-Paleozoic rocks, which make up the Cordillera miogeocline (Dover, 1994; Grantz and others, 1994). The Cordillera miogeocline rocks were affected episodically by plate tectonism that formed the present Cordillera orogenic belt. Plate convergence during Jurassic-Cretaceous time along the continental margin resulted in a complex of intraoceanic arcs, arcs on rifted continental crust, arc-related accretionary prisms, flysch basins, oceanic plateaus, and oceanic crustal rocks. Structural deformation, metamorphism, magmatism, and erosion, in turn, modified these rock (Dusel-Bacon, 1994). The oceanic crustal rocks define suture zones of either autoch- 


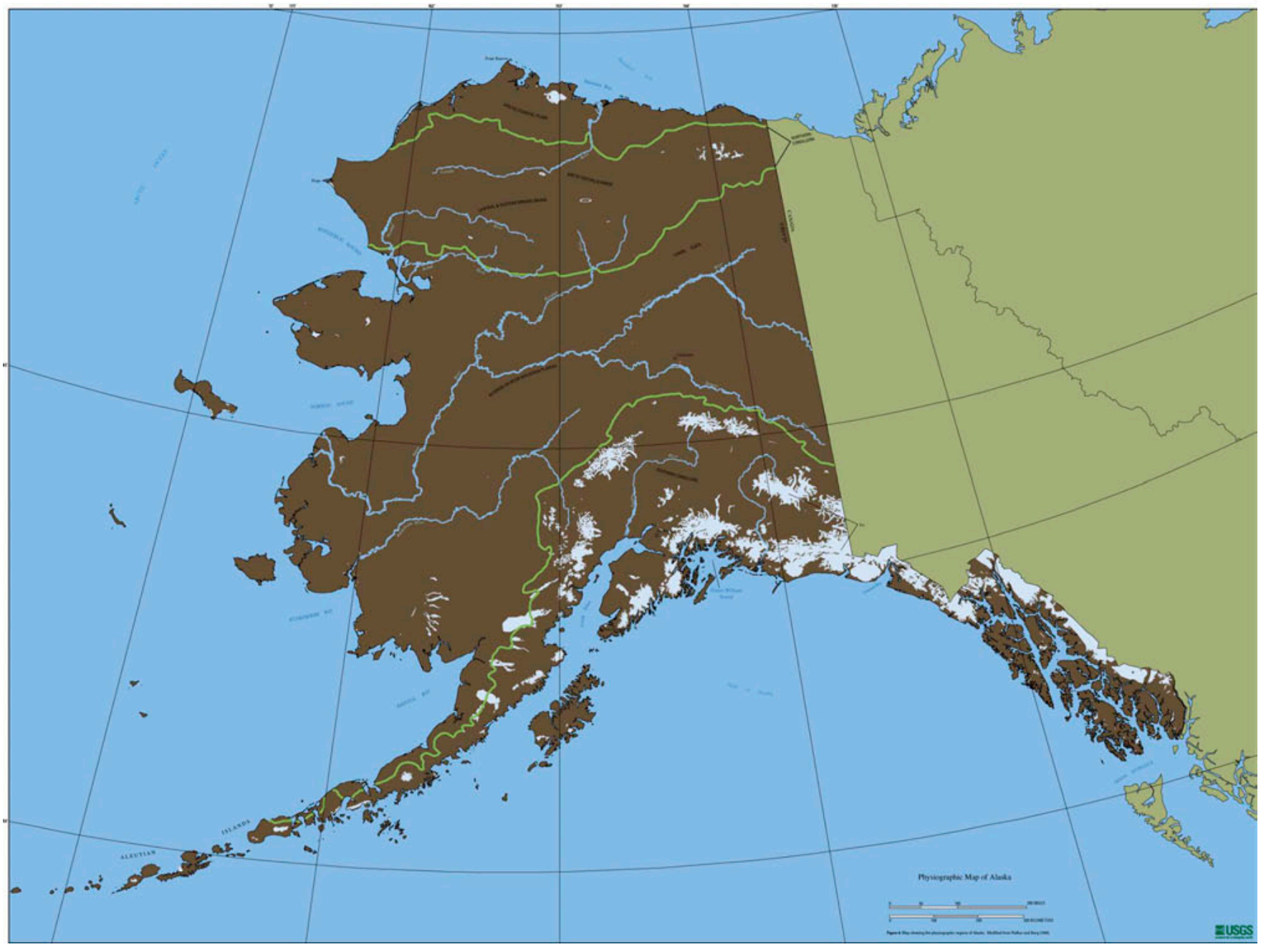

Figure 4. Map showing the physiographic regions of Alaska. Modified from Plafker and Berg (1994). 


\section{Alaska Coal Geology, Resources, and Coalbed Methane Potential}

thonous or paratochthonous rocks along which the Alaskan continental margin rocks are adjacent to noncontinental rocks.

The Alaskan continental margin developed an Andeantype arc system during mid-Cretaceous to Tertiary time as imposed by the convergence of the Kula and North American plate (Plafker and Berg, 1994; Nokleberg and others, 1994). During this time period, accreted terranes were welded to the continental margin by numerous arc-related volcanic, plutonic, and metamorphic events (Brew, 1994). Arc-related volcanic rocks and terrigenous sediments built much of western Alaska, and the arc-related accretionary prisms formed seaward of the volcanic arc (fig. 5). The present structural trends of Alaska were formed by extensive rotations and translations from Early Cretaceous to early Tertiary time. For example, during the Early Cretaceous, the Arctic Ocean basin developed by counterclockwise rotation of northern Alaska away from the Arctic Canadian continental margin (Plafker and Berg, 1994; Grantz and others, 1994). During Late Cretaceous and early Tertiary time the interior physiographic region was translated west several hundred kilometers along the Tintina and Denali faults (fig. 3). These faults, in turn, were followed by counterclockwise rotation that displaced preexisting transcurrent faults.
Tectonic movements along the transcurrent faults controlled depositional environments of the Tertiary coal-bearing rocks in the interior and southern Cordillera regions (Flores and Stanley, 1995). Movements, particularly along the Denali fault, dammed flow-through fluvial systems that drained alluvial plains north and south of the Alaska Range, where peat precursors accumulated in associated mires. Damming of the fluvial systems created lakes, which in turn drowned peatforming mires north of the Alaska Range. In addition, damming of fluvial systems shortened their headwaters, promoting erosion, high sediment dispersal, and consequently drowning of peat mires by detritus south of the Alaska Range.

\section{Origin of Alaska Coal}

Coal, containing more than 50 percent by weight and more than 70 percent by volume of organic matter, is composed of plant remains deposited as peat (Schopf, 1956). The vegetal remains accumulated under mainly reducing conditions beneath the ground-water table in mires or swamps. The high acidity of the water killed bacteria and fungi that would

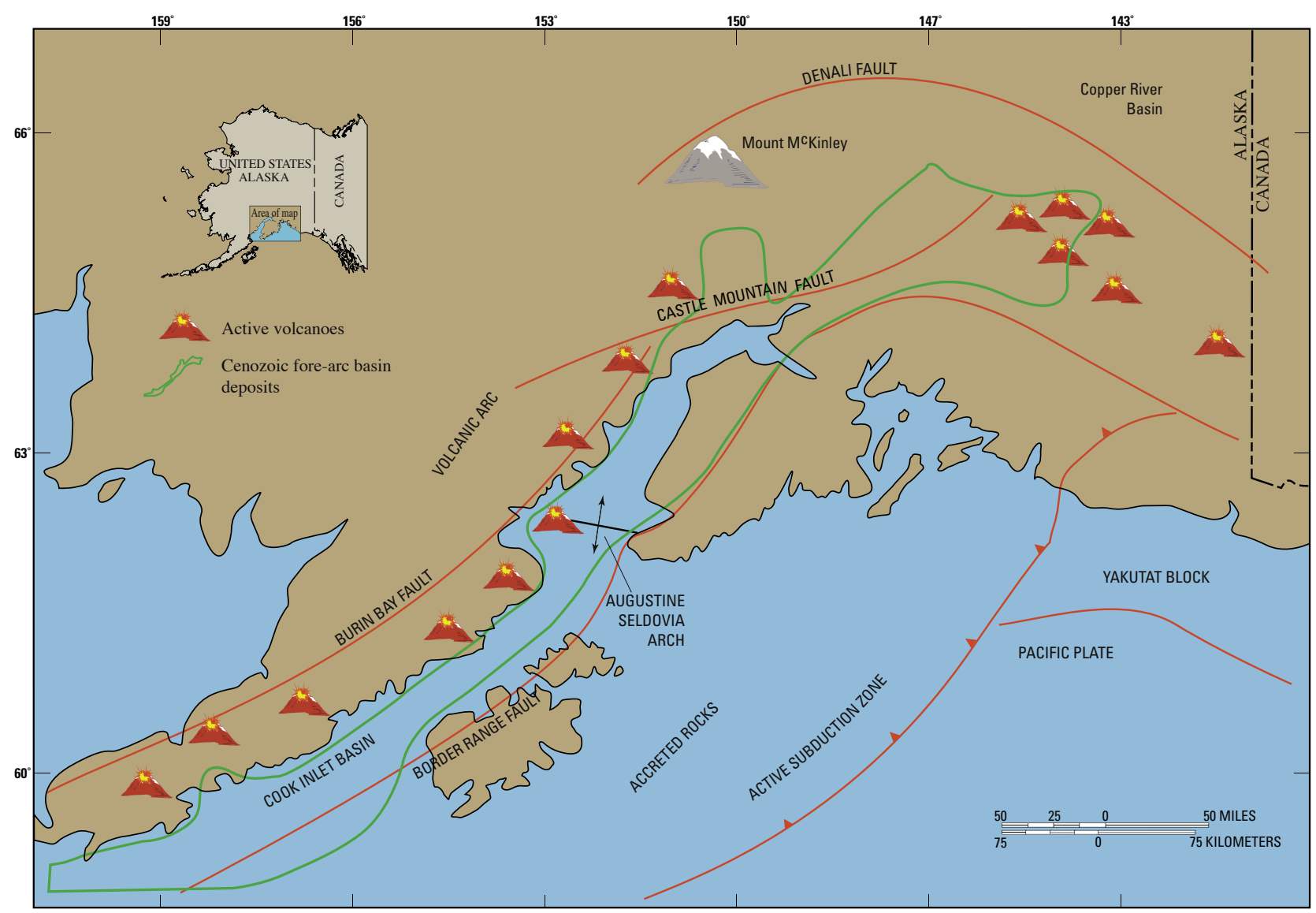

Figure 5. General tectonic framework of the Cook Inlet Basin, associated subduction zone, accreted terranes, and volcanic arc. Modified from Swenson (1997). 
otherwise have digested and completely oxidized the peat (Schopf, 1956).

Peat-forming mires developed mainly in alluvial and coastal plains that were drained by fluvial and deltaic distributary channels (Flores and Stricker, 1993a and b). Commonly, the coastal plains were barred seaward by barrier-bar systems that protected back-barrier mires from active marine sedimentation, permitting accumulation of peat deposits (Flores, Stricker, and Stiles, 1997; Flores and others, 1999). Abandoned areas in the coastal plains, which were far removed from active sedimentation, also served as platforms for peatmire development. In active sedimentation areas of the coastal plains, dense vegetation along margins of the mires juxtaposed with fluvial and distributary channels prevented flood water invasions and permitted peat accumulation. In regions where high rainfall rates existed, mires developed a raised topography that shielded them from sedimentation from adjoining rivers, particularly during floods. Preservation of these peat mires resulted from rapid subsidence, which promoted accommodation space and initiated burial of the peat deposits by overlying sediments, which led to subsequent compaction and metamorphism into coal.

The alluvial- and coastal-plain areas and associated mires in Alaska were formed from Paleozoic to late Tertiary time. The peat that accumulated in Alaska mires formed low-sulfur (average 0.3 percent) coal deposits, whereas in many other regions of the world, encroachment of the sea over peat-forming environments commonly brought sulfate-bearing sediments that transformed the peat into high-sulfur deposits. Additionally, when sediments flood portions of the peat mires, an increased $\mathrm{pH}$ typically enhances microbial activity within the top of the peat, which concentrates sulfur through degradation of plant material. Flooding of the mires also led to an increase of ash content of the peat due to settling of waterborne sediments.

Climate and (or) vegetation types may explain the accumulation of low-sulfur coal unique to Alaska, regardless of age. That is, the Alaskan coal contains low sulfur because of accumulation in mires developed in high paleolatitudes and in temperate paleoclimatic conditions (Affolter and Stricker, 1988, 1990). Alternatively, the vegetation may have evolved through time such that tropical or low paleolatitudinal plants became adapted to mires developed in high-paleolatitudinal regions.

The Alaskan peat-forming environments formed in depositional basins that were developed in the interior and margins of the State. Riverine plains, in which mires accumulated economic coal deposits, drained the interior basins (for example, Central Alaska-Nenana coal province; see fig. 1). Fluvial and deltaic coastal plains with associated mires accumulated economic coal deposits in margin basins (Northern AlaskaSlope and Southern Alaska-Cook Inlet coal provinces; see fig. 3). Coal that formed in these basins ranges from Mississippian to Miocene in age. The basins underwent detrital infilling after accumulation of the peat deposits followed by tectonic deformation that transformed these deposits into various ranks of coal.

The rank of a coal is a measure of the metamorphism that took place since deposition of the peat, due primarily to depth of burial, temperature, time, and pressure (Teichmüller and Teichmüller, 1968). The Earth's temperature increases with depth of burial (geothermal gradient), and the temperature necessary to metamorphose the peat to coal probably does not exceed $300^{\circ}-390^{\circ} \mathrm{F}\left(150^{\circ}-200^{\circ} \mathrm{C}\right)$. Time also plays an important role in coal rank because it controls coal composition. For example, peat coal buried for 50-65 Ma will contain higher volatile matter (subbituminous rank) than coal buried for $200 \mathrm{Ma}$, which contains low volatile matter (bituminous rank). Thus, Tertiary coals are generally subbituminous, and Cretaceous and Carboniferous coals are usually bituminous. This broad generalization, however, is not applicable in many geologic settings in Alaska. Along ancient plate margins and volcanic island arcs, where heat was produced either by igneous intrusions and volcanism or by increased pressure caused by tectonic compaction and compression, can increase coal rank, such as in the Matanuska coalfield.

\section{Coal Metamorphism, Composition, Rank, and Occurrence}

Metamorphism of peat results in transformation of plant parts (stems, leaves, and so forth) into macerals in coal. The plant vascular tissue parts such as cell walls (for example, cellulose and lignin of wood, leaves, roots, and humic cell contents) are transformed into a vitrinite (huminite) maceral, initially high in both oxygen and hydrogen. Plant waxes, secretions, resins, spores, and algae are converted into an exinite (liptinite) maceral that is high in hydrocarbons (fats and oils). Carbonized plant parts, the product of oxidation of organic matter, are changed into an inertinite maceral - for example, fossil charcoal or fusinite.

Varying degrees of metamorphism produce different maceral types. The vitrinite, exinite, and inertinite, which were formed by intense metamorphism, are unique to high-rank coal (for example, bituminous and anthracite). Low degree of coalification by less intense metamorphism yields a different physical category of macerals for low-rank coal such as in subbituminous coal and lignite. The vitrinite and exinite macerals may be correlated to huminite and liptinite macerals, respectively, in subbituminous coal and lignite (Stach, 1968; Neavel, 1981; Stach and others, 1982; Stanton and others, 1989). Economic properties of coals depend on the proportions of macerals, and the classification into various types is based on these proportions. Rao (1980), Rao and Wolff (1981), and Rao and Smith (1986) performed several petrographic studies of Alaskan coals, which show that coal rank and its suitability for various economic uses depends on moisture content, ash yield, and sulfur content. 


\begin{tabular}{|c|c|c|c|c|c|}
\hline & & \multicolumn{4}{|c|}{ Resource Classifications } \\
\hline \multirow{3}{*}{\multicolumn{2}{|c|}{ Coal province, coalfield, and age }} & \multicolumn{3}{|c|}{ Identified } & \multirow{3}{*}{$\begin{array}{l}\text { Undiscovered } \\
\text { Hypothetical }\end{array}$} \\
\hline & & \multicolumn{2}{|c|}{ Demonstrated } & \multirow{2}{*}{ Inferred } & \\
\hline & & Measured & Indicated & & \\
\hline \multirow{2}{*}{ Northern Alaska-Slope } & \multirow{2}{*}{$\begin{array}{r}\text { Tertiary } \\
\text { Cretaceous }\end{array}$} & & & & $670,000^{a}$ \\
\hline & & \multicolumn{3}{|c|}{$120,000^{c}$} & $3,200,000^{\mathrm{a}}$ \\
\hline \multicolumn{2}{|c|}{ Total for Northern Alaska-Slope } & \multicolumn{3}{|c|}{120,000} & $3,900,000$ \\
\hline \multirow{9}{*}{ Central Alaska-Nenana } & Healy Creek & \multicolumn{3}{|c|}{$1,000^{b}-1,360^{c}$} & $2,000^{b}$ \\
\hline & Lignite Creek & \multicolumn{3}{|c|}{$4,100^{c}-4,900^{b}$} & $7,000^{b}$ \\
\hline & Jarvis Creek & \multicolumn{3}{|c|}{$13^{\mathrm{e}}-77^{\mathrm{c}}$} & $175^{\mathrm{b}}$ \\
\hline & Wood River & $15^{\mathrm{c}}$ & $45^{\mathrm{c}}$ & $241^{\mathrm{c}}$ & \\
\hline & Wood River & \multicolumn{3}{|c|}{$275^{\mathrm{b}}$} & $350^{\mathrm{b}}$ \\
\hline & Rex Creek & & $9.5^{\mathrm{c}}$ & $113^{\mathrm{c}}$ & \\
\hline & Rex Creek & \multicolumn{3}{|c|}{$70^{\mathrm{b}}$} & $130^{\mathrm{b}}$ \\
\hline & \multirow{2}{*}{$\begin{array}{c}\text { Tatlanika Creek } \\
\text { Tatlanika Creek }\end{array}$} & & $117^{\circ}$ & $153^{\circ}$ & \\
\hline & & \multicolumn{3}{|c|}{$290^{\mathrm{b}}$} & $400^{\mathrm{b}}$ \\
\hline \multicolumn{2}{|c|}{ Total for Central Alaska-Nenana } & \multicolumn{3}{|c|}{$6,400-7,700$} & 10,000 \\
\hline \multirow{5}{*}{$\begin{array}{l}\text { Southern Alaska- } \\
\text { Cook Inlet }\end{array}$} & Matanuska & \multicolumn{3}{|c|}{$137^{\mathrm{c}}-200^{\mathrm{g}}$} & $2,400^{i}$ \\
\hline & Susitna-Beluga & \multicolumn{3}{|c|}{$2,400^{\mathrm{c}}-11,100^{\mathrm{b}}$} & $34,800^{\mathrm{b}}$ \\
\hline & Broad Pass & \multicolumn{3}{|c|}{$0.3^{\mathrm{f}}-64^{\mathrm{c}}$} & $13^{\mathrm{t}}-500^{\mathrm{b}}$ \\
\hline & Kenai (onshore) & \multicolumn{3}{|c|}{$318^{\mathrm{c}}-400^{\mathrm{h}}$} & $34,000^{\circ}-35,000^{b}$ \\
\hline & Kenai (offshore) & & & & $900,000^{d}-1,500,000^{b}$ \\
\hline \multicolumn{2}{|c|}{ Total for Southern Alaska-Cook Inlet } & \multicolumn{3}{|c|}{$2,900-12,000$} & $970,000-1,600,000$ \\
\hline \multicolumn{2}{|c|}{ Total coal resources for Provinces } & \multicolumn{3}{|c|}{$129,000-140,000$} & $4,900,000-5,500,000$ \\
\hline
\end{tabular}

The occurrence of different ranks of coal in Alaska may be related to juxtaposition with deformed belts and igneous intrusions. For example, the bituminous coal in the North Slope coalfields, which are juxtaposed to the Brooks Range deformed belt (synclines, anticlines, and thrust and strike-slip faults), is higher rank than the subbituminous coal away from the deformed belt (see fig. 1). In the Southern Alaska-Cook Inlet coalfields, the coal changes from anthracite to bituminous to subbituminous from east to west in the northeast part of the inlet in the Matanuska coalfield (see fig. 1). There, the Matanuska coalfield is bounded by the Talkeetna Mountains and flanked by the Castle Mountain Fault on the north and by the Chugach Mountains on the south (see fig. 3). In addition, numerous volcanic rocks have intruded into the coal-bearing rocks.

\section{Coal Resource Classification}

Wood and others (1983) defined the terminology used in this report for coal resource classification and estimates. The categories of the coal resource classification, arranged in the degree of decreasing geologic assurance as to nearness to points of control and the relative quality and quantity of geologic data, are (1) measured, (2) indicated, (3) inferred, and (4) hypothetical. The sum of the measured and indicated resources is termed demonstrated resource. The sum of the measured, indicated, and inferred is termed identified resource. The state of certainty of the existence of a quantity of resource is also based mainly on correlations of coal beds and enclosed rocks in relation to the thickness, overburden, rank, quality, and areal extent of the coal.

1. Measured coal resources have the highest degree of geologic assurance. Resource estimates are based partly on measurements from outcrops, trenches, drill holes, and mine workings and partly on thickness projection of correlatable beds, coal rank, and geologic data (not more than a specified distance and depth). The area of measured coal resources is within $0.25-\mathrm{mi}(0.4-\mathrm{km})$ radius.

2 . Indicated coal resources have a moderate degree of geologic assurance. Estimates of resources are based on projection of coal thickness and other geologic data from outcrops, trenches, mine workings, and drill holes for specified distance and depth beyond those used for the measured resources. The area of indicated coal resources is between 0.25 and $0.75 \mathrm{mi}(0.4$ and $1.2 \mathrm{~km})$ radii. 
3. Inferred coal resources have a low degree of geologic assurance. Estimates of resource are calculated by projection of thickness, sample, and geologic data from distant outcrops, trenches, workings, and drill holes for a specified distance and depth beyond those used for indicated resources. The area of inferred coal resources is between 0.75 and $3 \mathrm{mi}(1.2$ and 4.8 $\mathrm{km}$ ) radii. Estimates of coal thickness, extent, and quantity are based on inferred continuity, beyond measured and indicated resources, for which there is geologic evidence.

4. Hypothetical or undiscovered coal resources have the lowest degree of geologic assurance of these categories. Estimates of coal thickness, extent, and quantity are based on measurements and continuity of coal beyond parameters used in the inferred resources. The area of hypothetical coal resources is beyond a $3-\mathrm{mi}(4.8-\mathrm{km})$ radius.

Table 1 shows the coal-resource classification system of Alaska using the concepts of Wood and others (1983). The estimates are determined from previous works (Wahrhaftig and Hickcox, 1955; Barnes and Cobb, 1959; Barnes, 1967a; McGee and Emmel, written commun., 1979; Merritt and Belowich, 1984; Merritt and Hawley, 1986; Sable and Stricker, 1987; Stricker, 1991; Wahrhaftig and others, 1994), which used different resource categories. For the present study, we analyzed and synthesized the various coal resource assessments of these workers and reconstructed them following the coal-resource classification system of the U.S. Geological Survey (Circular 891). The revision of the Alaska coal resource assessments here presented provides (1) a simplified and unified account of the coal resources; (2) a uniform application of the guidelines and principles outlined in Wood and others (1983); (3) standardized coal resource estimates comparable to those by different workers using the same data; and (4) some idea as to economic availability of the coal. Measurements are reported in English units followed by metric units given in parentheses.

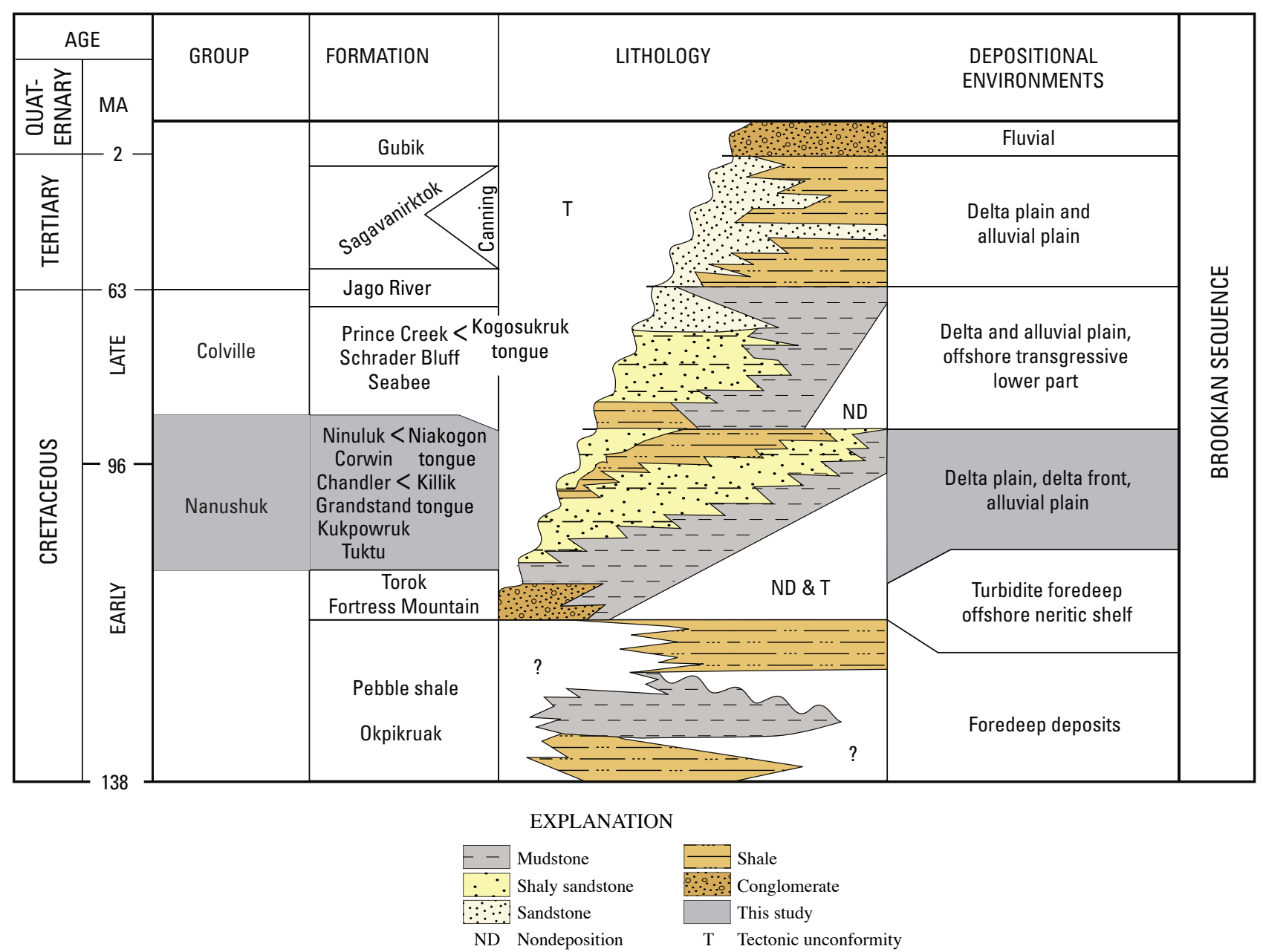

Figure 6. Stratigraphic column of the Mesozoic and Cenozoic rocks in the Northern Alaska-Slope coal province. Modified from Sable and Stricker (1987). 


\section{Distribution of Coal in Alaska}

Wood and Bour (1988) identified 50 coalfields and occurrences in Alaska (fig. 1). A coalfield is a discrete area that contains coal-bearing strata with one or more coal beds. Coal occurrence is an outcrop that contains one or more coal beds that are isolated and cannot be correlated to other coal-bearing outcrops. The bulk (87 percent) of the known coal resources of Alaska are in the three previously mentioned coal provinces: (1) the Northern Alaska-Slope, (2) Central Alaska-Nenana, and (3) Southern Alaska-Cook Inlet coal provinces (modified from Wahrhaftig and others, 1994; fig. 1). The bulk of the resources in Northern Alaska-Slope coal province are contained in the Cretaceous and Tertiary coal-bearing rocks. The coal resources in the Central Alaska-Nenana and the Southern Alaska-Cook Inlet are contained in Tertiary rocks.

\section{Northern Alaska-Slope Coal Province}

The Northern Alaska-Slope coal province (fig. 1) is the largest in the State. It is situated at lat $69^{\circ} \mathrm{N}$. and includes about $32,000 \mathrm{mi}^{2}\left(82,880 \mathrm{~km}^{2}\right)$ underlain by coal-bearing rocks, both near the surface and in the deep subsurface (see figs. 2 and 3). Rocks in this coal province range in age from Precambrian to Holocene; a representative columnar section is shown in figure 6 .

The Northern Alaska-Slope coal province (fig. 1) consists of Cretaceous and Tertiary sedimentary wedges shed to the north-northeast from the Brooks Range during the Laramide orogeny. Sedimentary wedges were also shed eastward from now-collapsed highlands in the present Chukchi basin, into a deep trough that lay between the Brooks Range and the Barrow arch. The coal-bearing rocks were deposited in coastal plains drained by fluvial and deltaic distributary channels that flowed into the ancestral Beaufort Sea. Peat coal was deposited mainly in mires in highly constructive (river-dominated), progradational delta plains (for example, Corwin and Umiat deltas of Ahlbrandt and others, 1979; Roehler and Stricker, 1979; Huffman and others, 1985). Although these deltas were highly constructional systems, they were increasingly influenced by marine transgressions resulting in destructive deltas (Huffman and others, 1985, 1988). Sea-level rise reworked the deltaic sediments into barrier bars forming back-barrier mires. Deltaic sediments grade updip toward the Brooks Range uplift into coarse fluvial sediments (sandstones and conglomerates) that were deposited in alluvial fans and braided and meandering rivers. The Cretaceous and Tertiary coal deposits, combined in the Northern Alaska-Slope coal province, are the largest in Alaska. The remoteness of these coal deposits and the formidable logistic and environmental problems that come with their exploitation make them presently uneconomic. However, because of planned infrastructures (for example, gas pipeline), these coal deposits may be targeted for future coalbed methane development.

\section{Cretaceous Rocks}

The most important Cretaceous coal-bearing rocks in the Northern Alaska-Slope province are in the Nanushuk and Colville Groups (Collier, 1906; Tailleur, 1965; Barnes, 1967b; Conwell and Triplehorn, 1976; Bird and Andrews, 1979; Molenaar and others, 1984; Stricker, 1991). It should be noted that coal deposits also occur in Mississippian rocks, but they are of minor importance and are not discussed in this report.

Coal at Corwin Bluffs, on the Chukchi Sea north of Cape Lisburne, was mined as early as 1879 for use in whaling ships (Schrader, 1904). Various mining companies have carried out preliminary investigations since 1944. During a fuel shortage in Point Barrow from 1943 to 1944, at least one small mine was in operation on the Meade River (Clark, 1973). Although the Meade River coal mine demonstrated the feasibility of mining under permafrost conditions, active mining has yet to materialize in the Northern Alaska-Slope coal province.

Collier (1906) first described the Cretaceous coal deposits at Corwin Bluff. Later studies showed that coal occurs in outcrops in the foothills belt (Chapman and Sable, 1960) and beneath the Arctic coastal plain (Tailleur and Brosgé, 1976). Cretaceous coal-bearing rocks probably also exist beneath the Chukchi Sea (Grantz and others, 1975; Affolter and Stricker, 1987b) and the Beaufort Sea (Affolter and Stricker, 1987b).

\section{Nanushuk Group}

The Lower Cretaceous Nanushuk Group includes, from bottom to top, the Tuktu, Kukpowruk, Grandstand, Chandler, Corwin, and Ninuluk Formations (fig. 6); thickness is as much as $9,800 \mathrm{ft}$ thick $(3,000 \mathrm{~m})$. It consists of a marine sequence that includes the Kukpowruk, Tuktu, and Grandstand Formations and a nonmarine sequence that includes the Corwin Formation and the Killik Tongue of the Chandler Formation (Sable and Stricker, 1987). Approximately 150 coal beds, with individual beds ranging from a few inches (a few centimeters) to $20.2 \mathrm{ft}(6.1 \mathrm{~m})$ thick, occur in the middle and upper parts of the Nanushuk Group (Callahan and Sloan, 1978). Rocks exposed at Corwin Bluffs include coal beds from 5.5 to $8.8 \mathrm{ft}$ thick ( 1.7 to $2.7 \mathrm{~m}$ ) (fig. 7), and those at Cape Beaufort contain coal beds 11 to $17 \mathrm{ft}$ thick (3.4 to 5.2 $\mathrm{m})$. Along the valley walls of the Kukpowruk River, a coal bed as much $20.2 \mathrm{ft}$ thick $(6.1 \mathrm{~m})$ was described by Sanders (1981). Barnes (1967b) reported as many as 60 coal beds within a 4,600-ft-thick $(1,400-\mathrm{m})$ sequence in the Koalak area. Many of these coal beds are of bituminous and subbituminous rank. A net coal thickness greater than $350 \mathrm{ft}(106 \mathrm{~m})$ in the Nanushuk Group in this area and surrounding western part of the National Petroleum Reserve-Alaska (NPRA) is shown in figure 8.

The Nanushuk Group consists of an offlap, postorogenic molasse sequence deposited on a passive continental margin. 


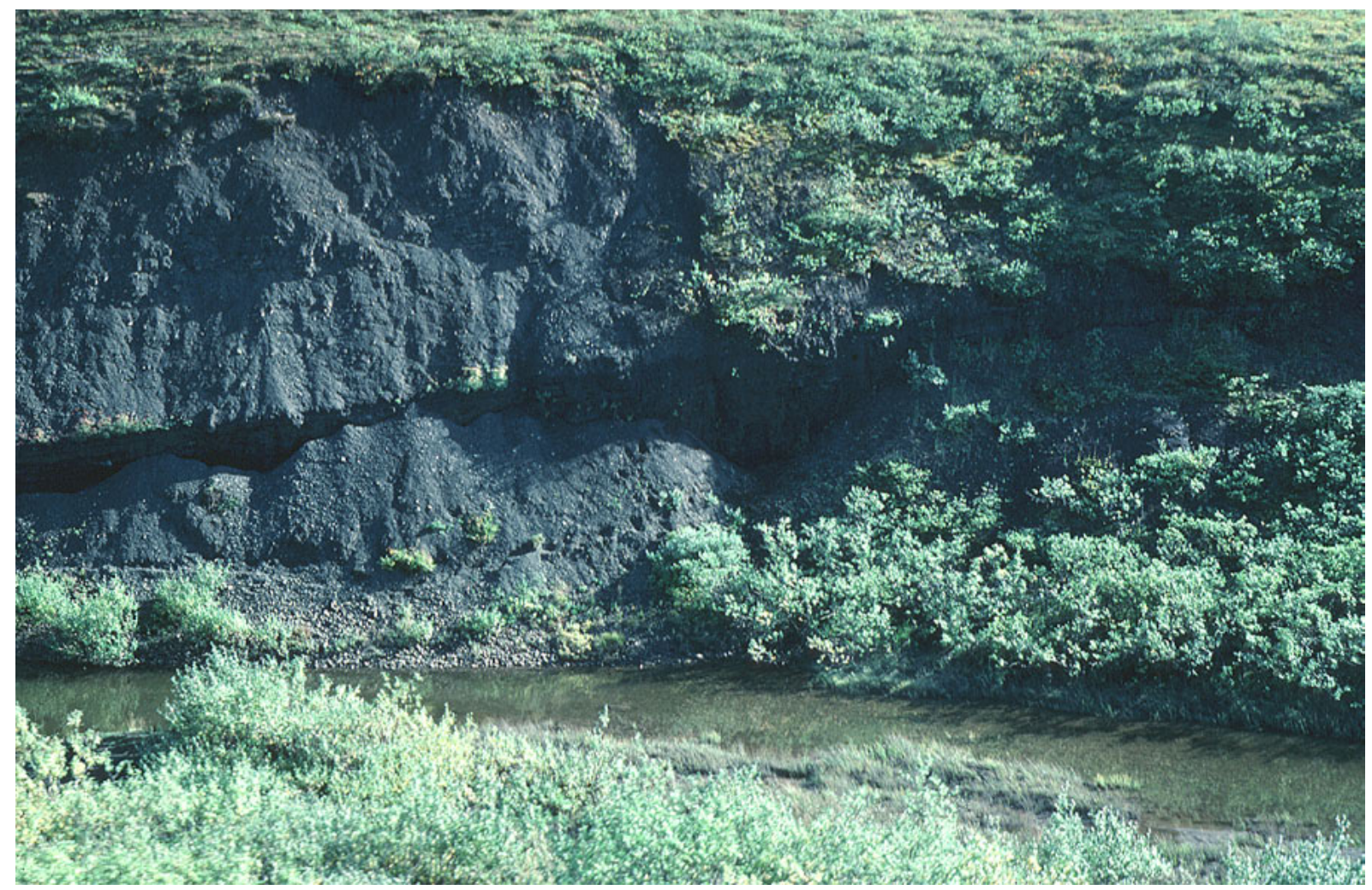

Figure 7. Photograph of a coal bed (about 20 feet thick) in the Nanushuk Group.

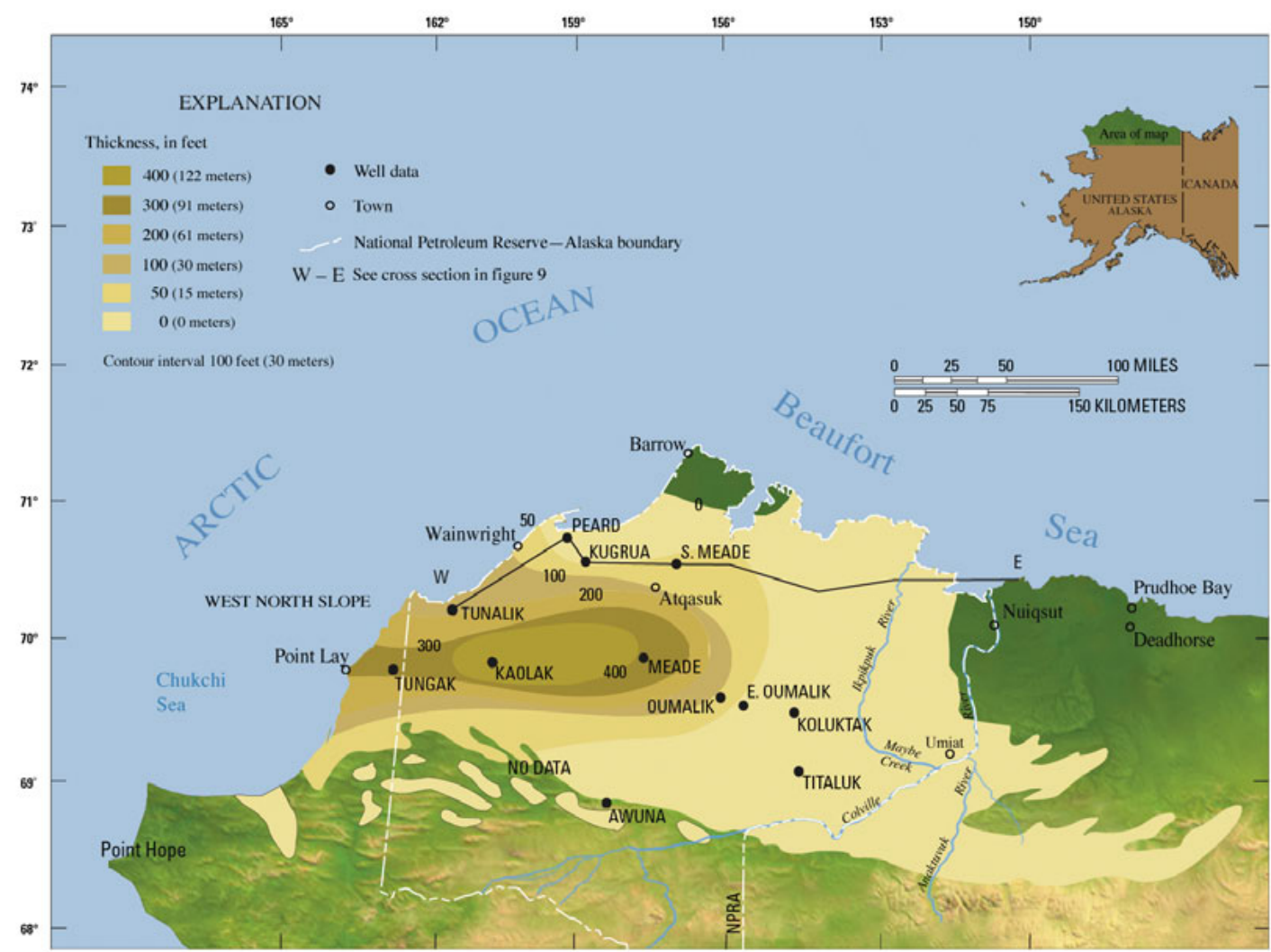

Figure 8. Net coal thickness map of the Nanushuk Group in the western part of the Northern AlaskaSlope coal province. See figure 9 for line of cross section. Modified from Sable and Stricker (1987). 
The progressive progradational relation of the sedimentary units of the Nanushuk Group is depicted in figure 9. The strata were deposited by fluvial-dominated systems of the Corwin delta in the western part and the Umiat delta in the central part of the Northern Alaska-Slope coal province (Ahlbrandt and others, 1979; Huffman and others, 1985).

The Kukpowruk Formation in the western part of the Northern Alaska-Slope coal province consists of delta frontshoreline deposits that grade upward and intertongue with the nonmarine, coal-bearing Corwin and Chandler Formations (fig. 6). The Kukpowruk Formation, composed mainly of delta-front sandstones, ranges in thickness from 2,000 to $3,900 \mathrm{ft}$ (610 to $1,200 \mathrm{~m})$ in the outcrop belt in the northern foothills. The Corwin Formation consists of alluvial and deltaplain shale, sandstone, conglomerate, and coal (Roehler and Stricker, 1979). This formation, although more than $11,300 \mathrm{ft}$ thick $(3,450 \mathrm{~m})$ at Corwin Bluffs along the Arctic coast, thins eastward to zero in the subsurface near the Colville River.

In the central Northern Alaska-Slope coal province, the rock succession consists of complexes of nonmarine and marginal marine rocks overlying and intertonguing with marine rocks. The marginal marine to marine (basin shelf-slope) Tuktu Formation, more than 8,000 ft thick $(2,400 \mathrm{~m})$, intertongues with the delta-front and lower delta-plain Grandstand Formation (fig. 6). The Grandstand Formation is overlain by, and intertongues with, the Killik Tongue of the Chandler Formation, which is an upper delta-plain rock unit. In the upper part of the stratigraphic section, a tongue of the Ninuluk Formation, which intertongues with the overlying Niakogon Tongue (fig. 6), overlies the Killik Tongue. Molenaar (1985) indicated that the Seabee Formation of the Colville Group interfingers with both the Ninuluk Formation and Niakogon Tongue of the Chandler Formation.

As depicted in figure 9, the vertical stacking of shoreline deposits of the Grandstand Formation marks a progradational sequence that may be correlated with the occurrence westward (landward) of numerous thick coal beds in the Corwin Formation. The progradational or regressive phase led to the stacking of shoreline deposits at the regressive maximum, which was described by Fassett and Hinds (1971), Ryer (1981), and Flores and Cross (1991). These studies have shown that most coal beds occur at the top, and landward, of shoreline deposits

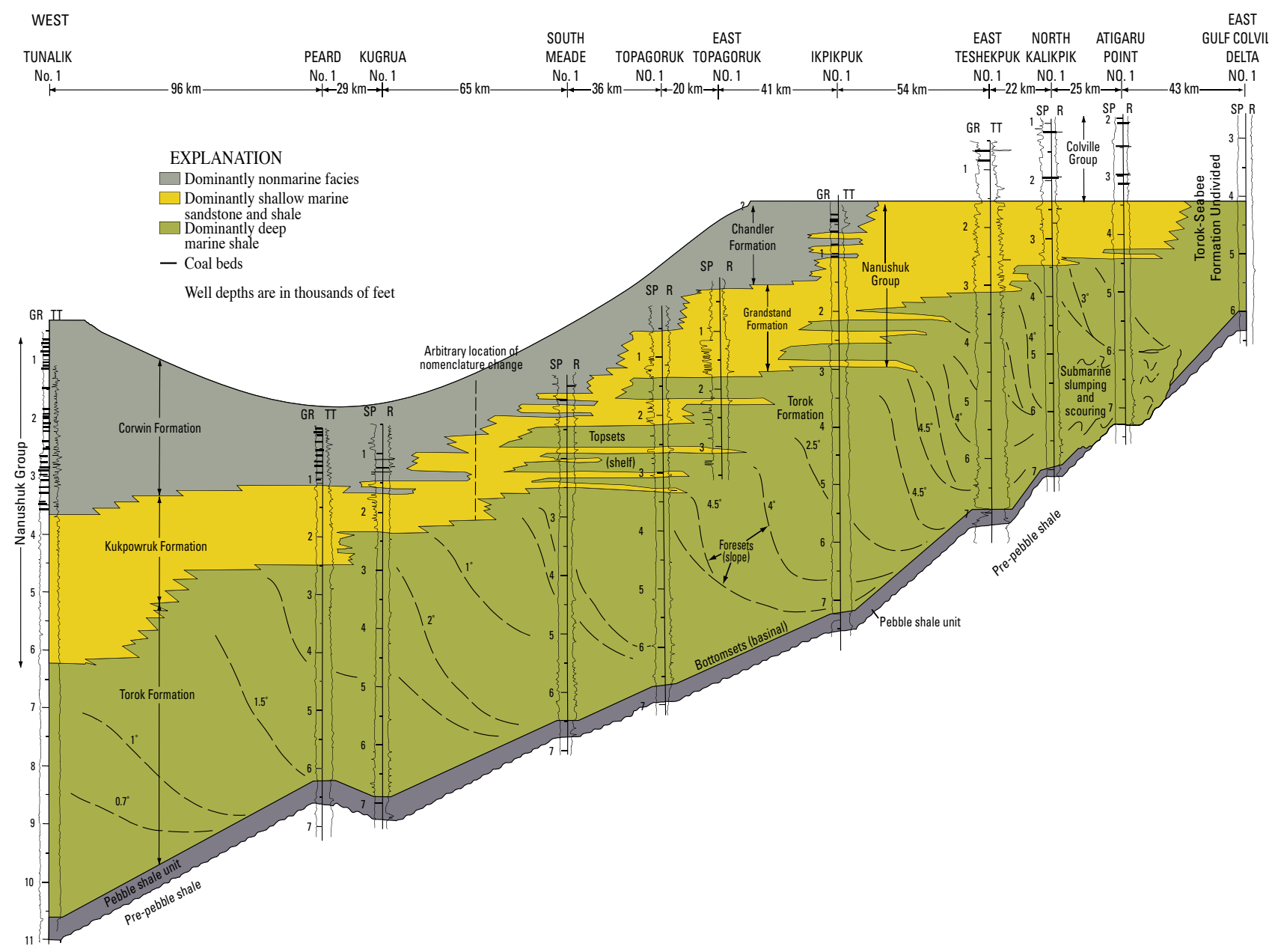

Figure 9. Cross section showing the Nanushuk progradation sequences. Modified from Molenaar, (1985). See figure 8 for location of the cross section. 


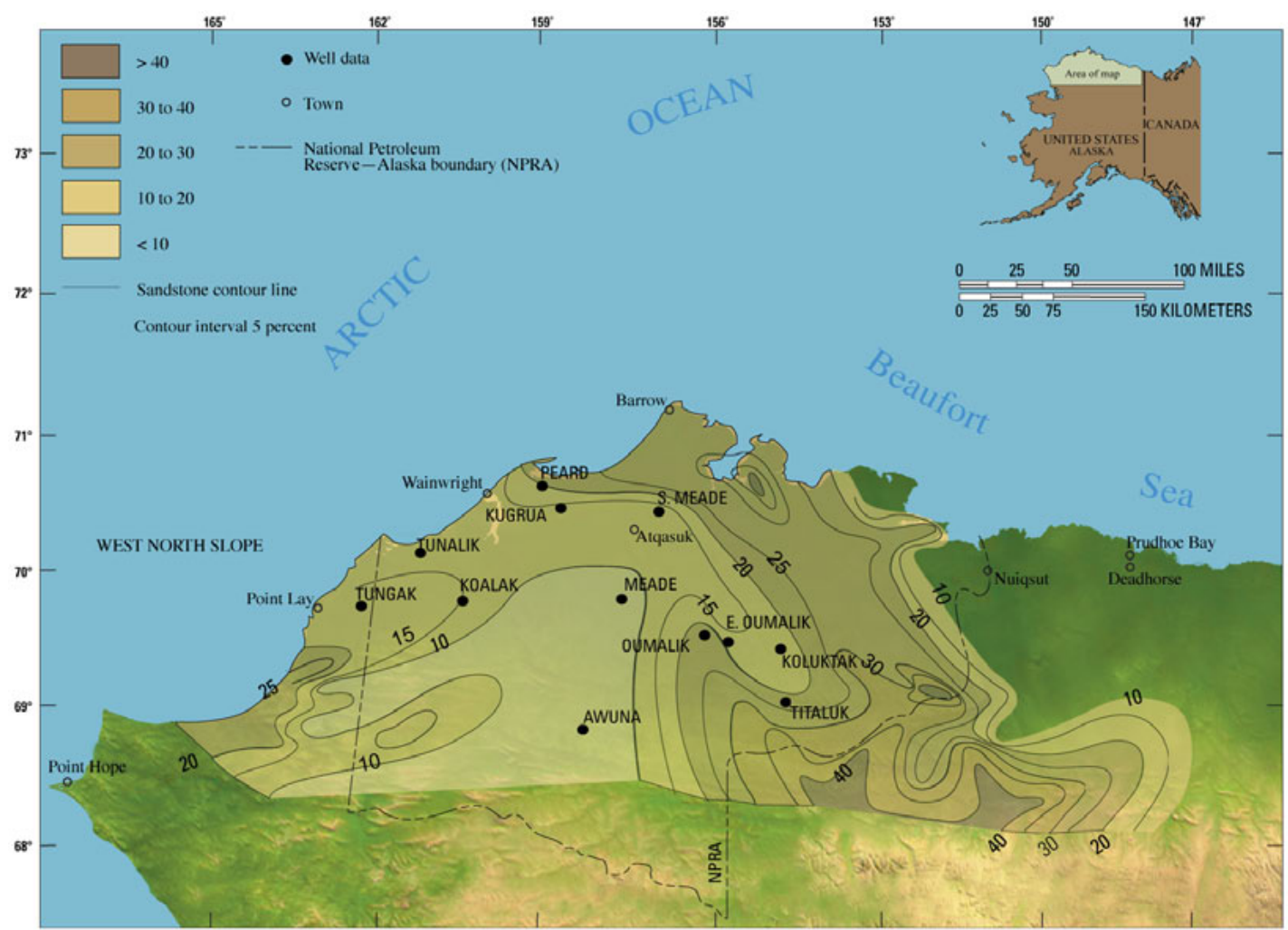

Figure 10. Sandstone percentage contour map in the Northern Alaska-Slope coal province. Modified from Huffman and others (1985).

from progradational events. However, the thickest coal, most extensive, and greatest volume of coal occur preferentially in stratigraphic positions where the shoreline deposits of successive progradational events are stacked vertically (Flores and Cross, 1991).

The Umiat deltaic sediments reflect a higher degree of reworking than the Colville deltaic sediments as indicated by a larger sandstone percentage (fig. 10; Ahlbrandt and others, 1979; Huffman and others, 1985). The Umiat delta (fig. 11A-D), probably being derived from a smaller source, also contains a smaller sediment volume than does the Corwin delta. Molenaar (1981, 1985) suggested that the Corwin delta formed earlier than the Umiat delta and that the two merged during Albian time without specific demarcation (fig. 11A-D). The Corwin delta continued to be the dominant depositional feature. The Meade arch, which extended southward from Point Barrow in Brookian time, probably did not play an active part in controlling the depocenters of the deltas. Paleogeographic interpretations of Nanushuk deposition by Molenaar $(1981,1985)$ and Huffman and others (1985) stressed the dominant east-northeast progradation of the Nanushuk prodelta slope sediments. These studies also showed a strong northwestward concentration of sandstone in the upper part of the Nanushuk Group, from Umiat toward Point Barrow and parallel to the paleoshoreline. This concentration also indicates that northwestward longshore currents probably transported sand from the Umiat delta along the active shelf of the Corwin delta front (Huffman and others, 1985). The sand accumula- tion represents offshore bars that shielded coastal plain-back barrier mires from detrital sedimentation, resulting in the most prolific coal-forming Nanushuk deltaic environments in the western Northern Alaska-Slope coal province.

Spicer (1987) reported that the paleoclimate of the North Slope during Albian to Cenomanian time was cool temperate with annual temperature varying $5^{\circ}-50^{\circ} \mathrm{F}\left(3^{\circ}-10^{\circ} \mathrm{C}\right)$. Rainfall was sufficient to sustain the vegetation of peat mires, resulting in thick accumulation of peat deposits. Tree growth rings on the North Slope indicate a rapid change from summer to winter conditions during the Albian to Cenomanian (Spicer, 1987). Precipitation was also distributed throughout the year in a manner to preclude oxidation and loss of organic material in the peat mires. However, Rao (1980) reported that there was a drying upward trend in the peat mires.

\section{Colville Group}

The Upper Cretaceous Colville Group, a Brookian sequence younger than the Nanushuk Group, contains, from bottom to top, the Seabee, Schrader Bluff, and Prince Creek Formations (see fig. 6). The group is as much as $5,000 \mathrm{ft}$ $(1,525 \mathrm{~m})$ thick, consists of a marine interval (Seabee Formation), marine interval (Schrader Bluff Formation), and a coal-bearing, nonmarine interval (Prince Creek Formation).

The coal beds of the Colville Group in the vicinity of Umiat and Maybe Creek (see fig. 8) vary individually from 13 
A

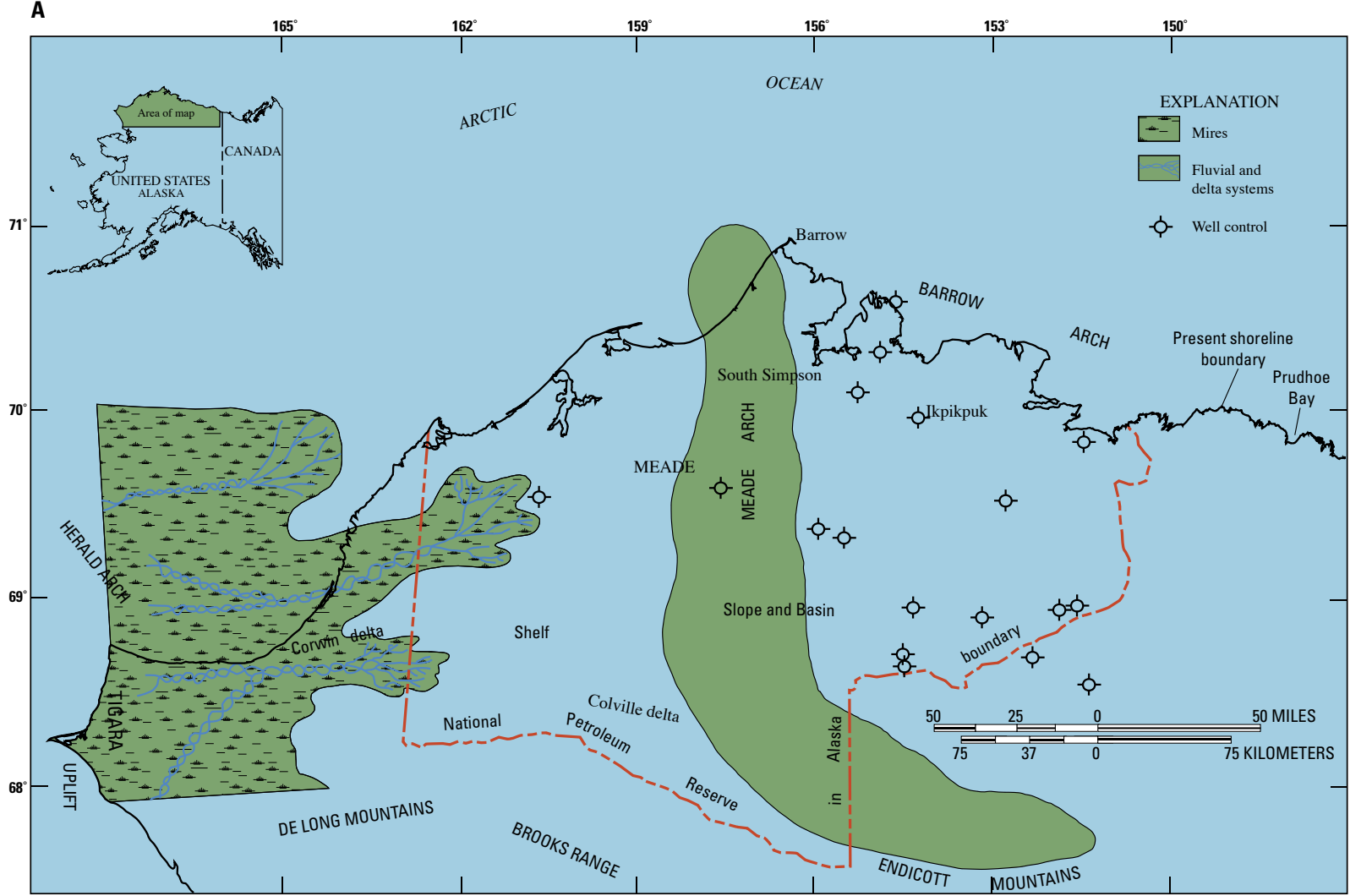

Figure 11. Paleogeographic maps showing the depositional environments of the Nanushuk Group in the central Northern Alaska-Slope coal province. A, Early to middle Albian time. Modified from Huffman and others (1985).

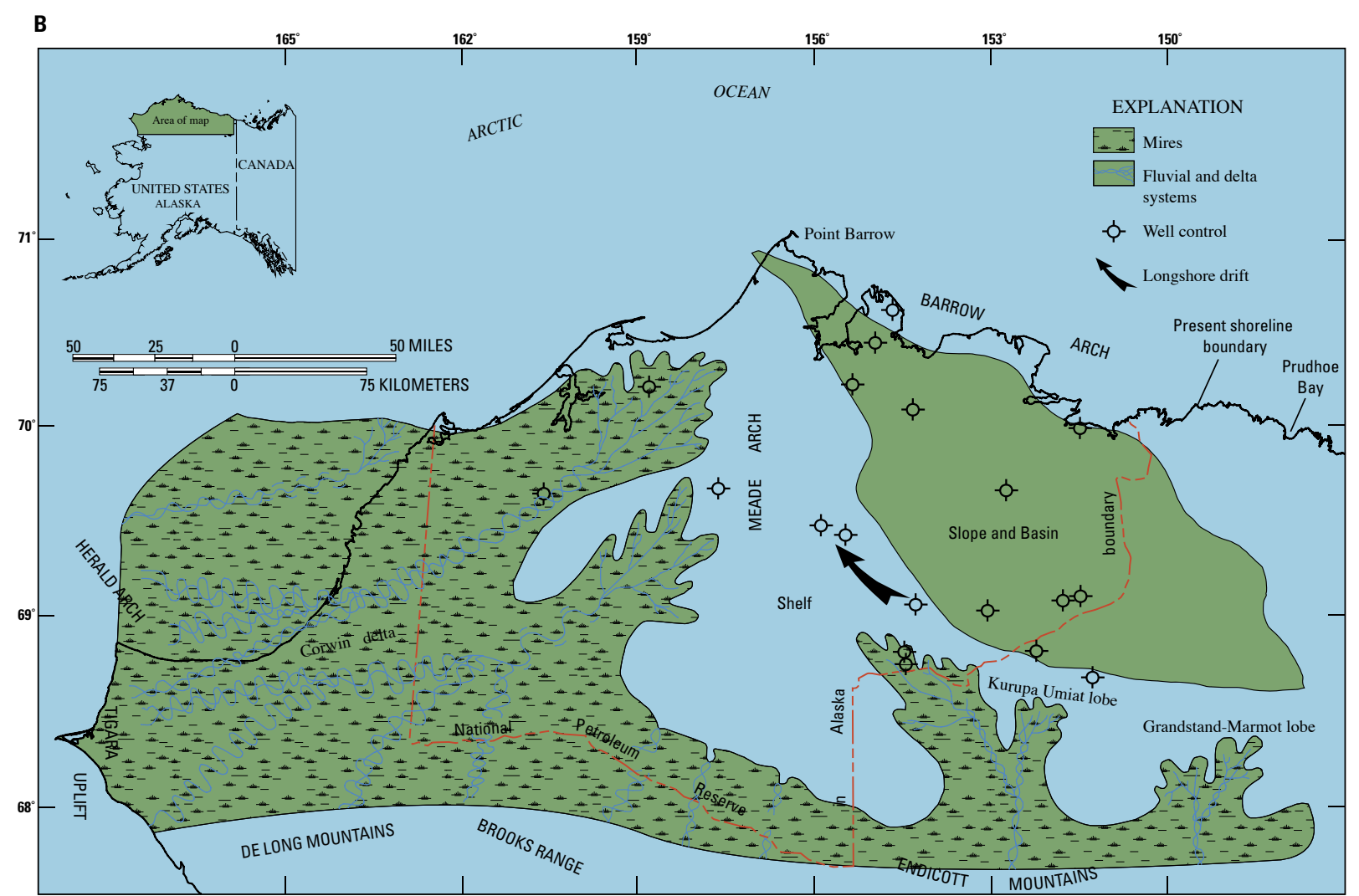

Figure 11. Paleogeographic maps showing the depositional environments of the Nanushuk Group in the central Northern Alaska-Slope coal province. B, Middle to late Albian time. Modified from Huffman and others (1985). 


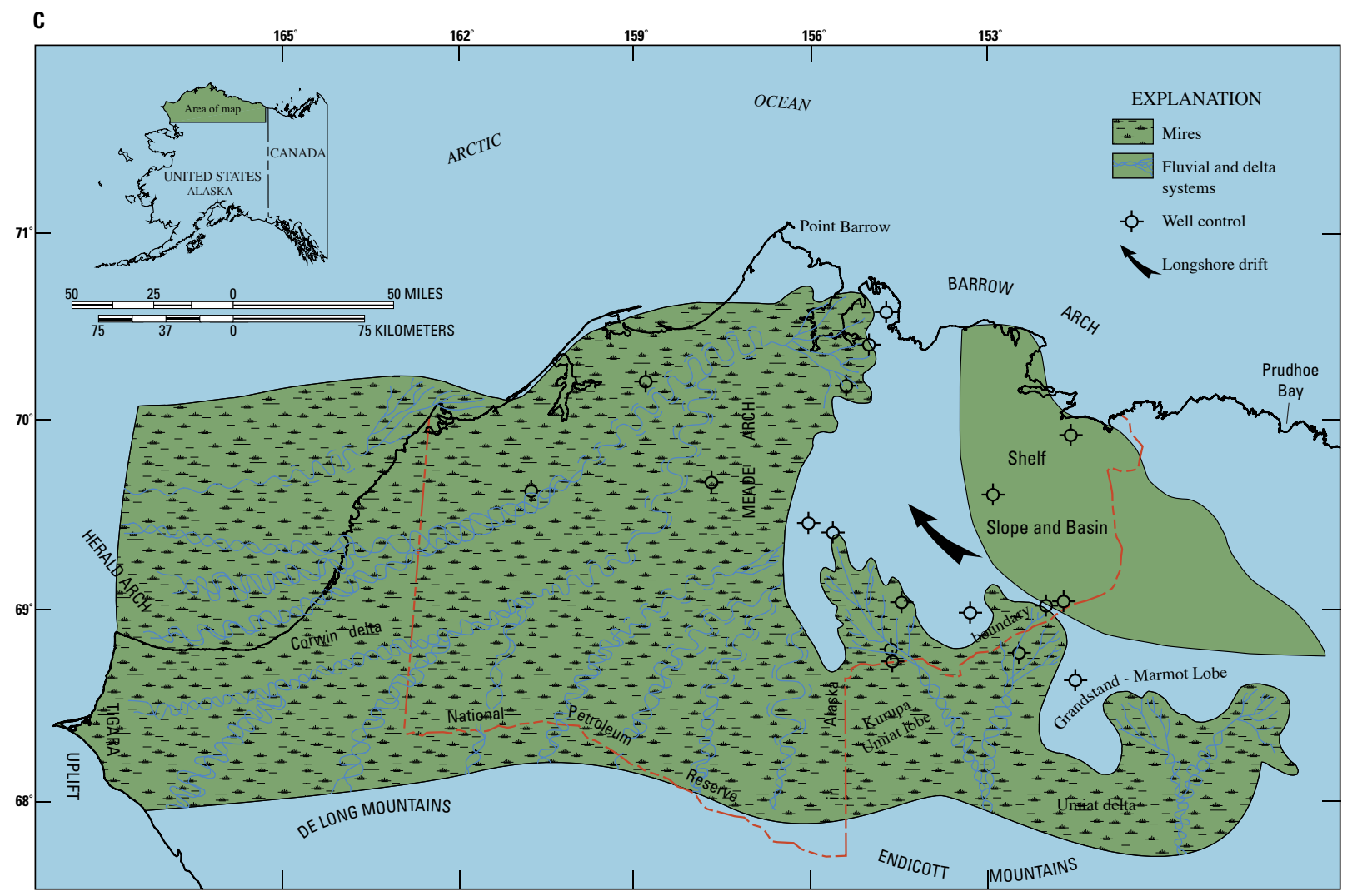

Figure 11. Paleogeographic maps showing the depositional environments of the Nanushuk Group in the central Northern Alaska-Slope coal province. C, Late Albian to Cenomanian (?) time. Modified from Huffman and others (1985).

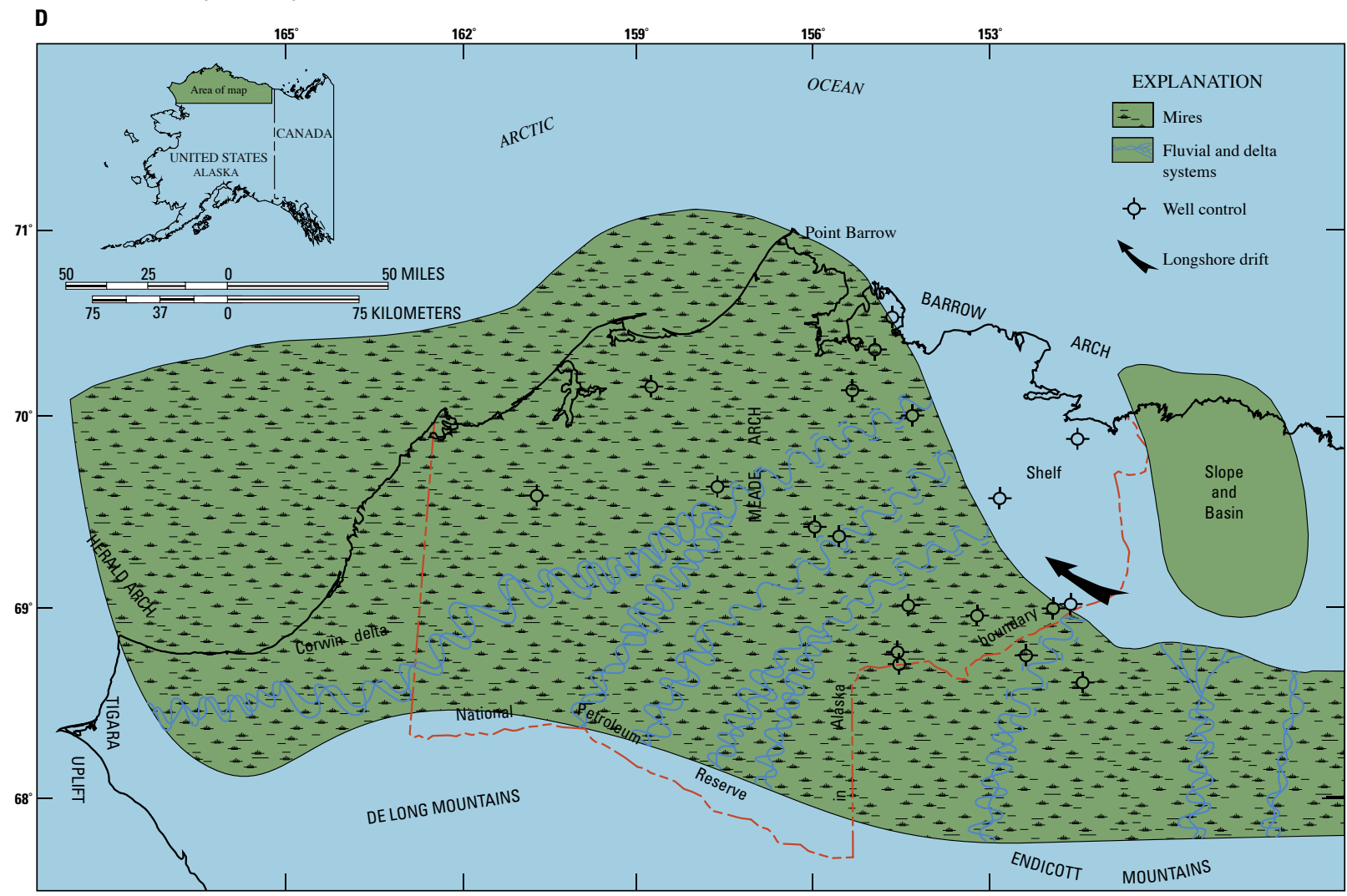

Figure 11. Paleogeographic maps showing the depositional environments of the Nanushuk Group in the central Northern Alaska-Slope coal province. D, Cenomanian time (maximum regression). Modified from Huffman and others (1985). 
to $39 \mathrm{ft}$ (4 to $12 \mathrm{~m}$ ) thick (Brosgé and Whittington, 1966). On the lower Colville River, the coal beds of the Colville Group range from 13 to $39 \mathrm{ft}$ (4 to $12 \mathrm{~m}$ ) thick (Brosgé and Whittington, 1966). Coal beds in the subsurface are typically less than $39 \mathrm{ft}(12 \mathrm{~m})$ thick with a 19-ft-thick $(6 \mathrm{~m})$ zone of coal interbedded with black shale and bentonite described from the Square Lake Test Well No. 1 core as a bony coal (Collins, 1959).

Recent work by R.M. Flores and G.D. Stricker and other geologists from the USGS (Dave Houseknecht and Ken Takahashi) and Alaska Division of Oil and Gas Commission (Mark Myers, Don Brizzolara, and Tim Ryherd) in July, 2002 of outcrops of the Kogosukruk Tongue (see fig. 6) of the Prince Creek Formation at the bluffs along the Colville River below the mouth of the Anaktuvuk River (see fig. 8) shows coal beds ranging from a few inches (a few centimeters) to as much as $9 \mathrm{ft}(2.7 \mathrm{~m})$ thick (fig. 12). Upstream from this outcrop, the Kogosukruk Tongue is underlain by the upper part of the Sentinel Hill Member of the Schrader Bluff Formation, which is composed of coarsening-upward bentonitic mudstone, siltstone, and sandstone; the sandstone thickens and coarsens upward. The uppermost sandstone bed of the Sentinel Hill Member, which is rooted at the top, in turn, is overlain by a $3.5 \mathrm{ft}$-thick coal-carbonaceous mudstone bed of the Kogosukruk Tongue, with both beds separated by an erosional surface or probably a sequence boundary. The coarsening-upward Sentinel Hill Member was probably deposited in a delta front.
The coal-carbonaceous mudstone bed and overlying interbedded coal, bentonitic mudstone and siltstone, and mediumgrained to pebbly conglomeratic, stacked erosional-based sandstone of the Kogosukruk Tongue were probably deposited in fluvial environments.

Coal beds of the Colville Group have been studied less than those of the Nanushuk Group because they have shown less economic potential; most are thinner, have a high ash yield, and are of lower rank than those in the Nanushuk Group. Many of these coals are described as lignites.

\section{Cretaceous-Tertiary Rocks}

The contact between the Cretaceous and Tertiary rocks in the Northern Alaska-Slope coal province was determined to be gradational or conformable by Molenaar (1983) and Molenaar and others (1984). This led to difficulty in defining a specific contact and also contributed to inclusion of the Upper Cretaceous formations of the Colville Group with the overlying Tertiary Sagavanirktok Formation. Molenaar (1983) described this contact as diachronous resulting from a depositional continuum from the Cretaceous to Tertiary time. That is, the Cretaceous deltaic systems (for example, Corwin delta) that prograded northeastward also continued this advance seaward during Tertiary time. Thus, the nonmarine and marine deposits

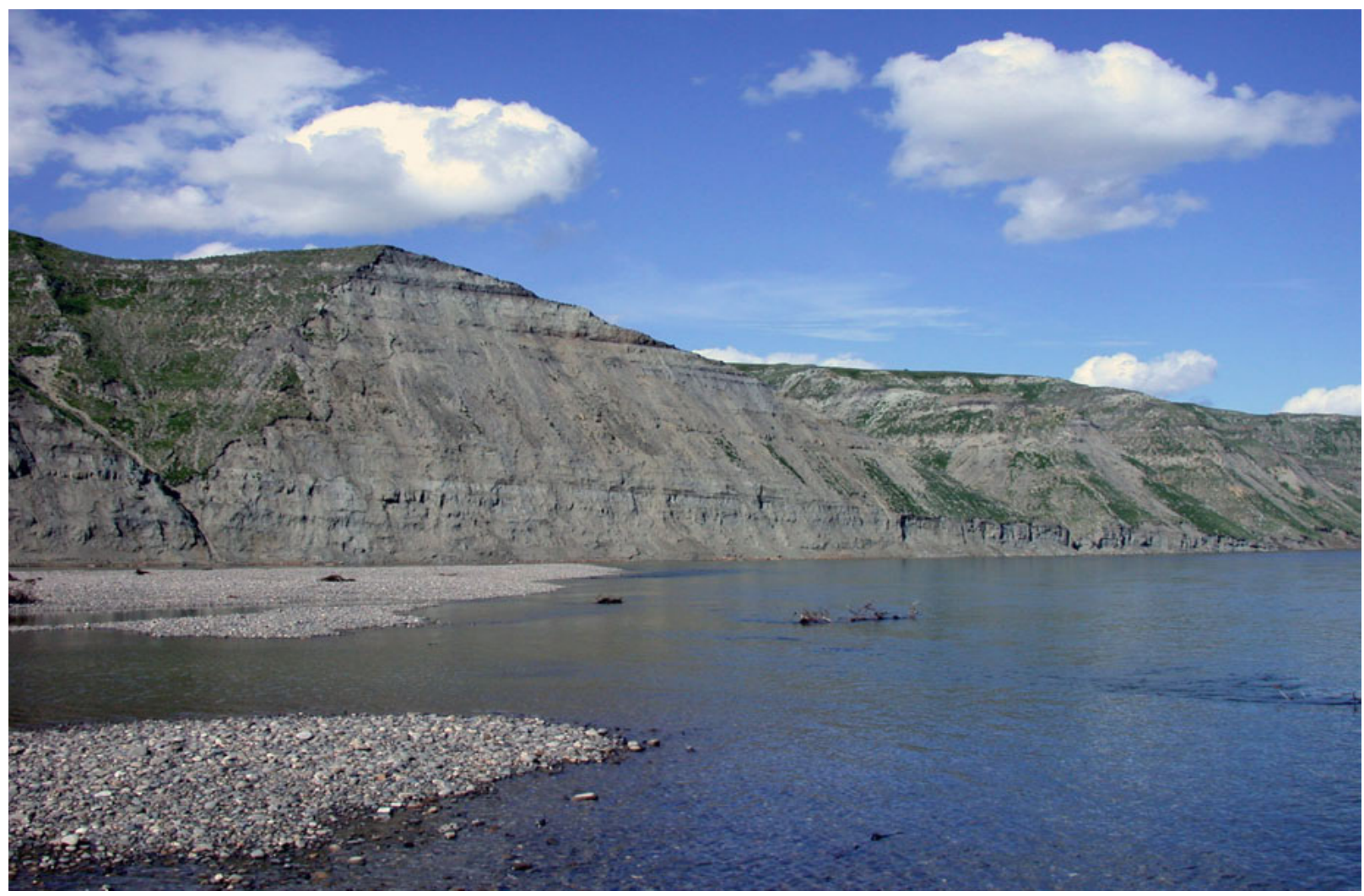

Figure 12. Photograph of interbedded coal, sandstones, siltstone, and mudstone of the Kogosukruk Tongue of the Prince Creek Formation along the lower Colville River downstream from the mouth of the Anaktuvuk River. 


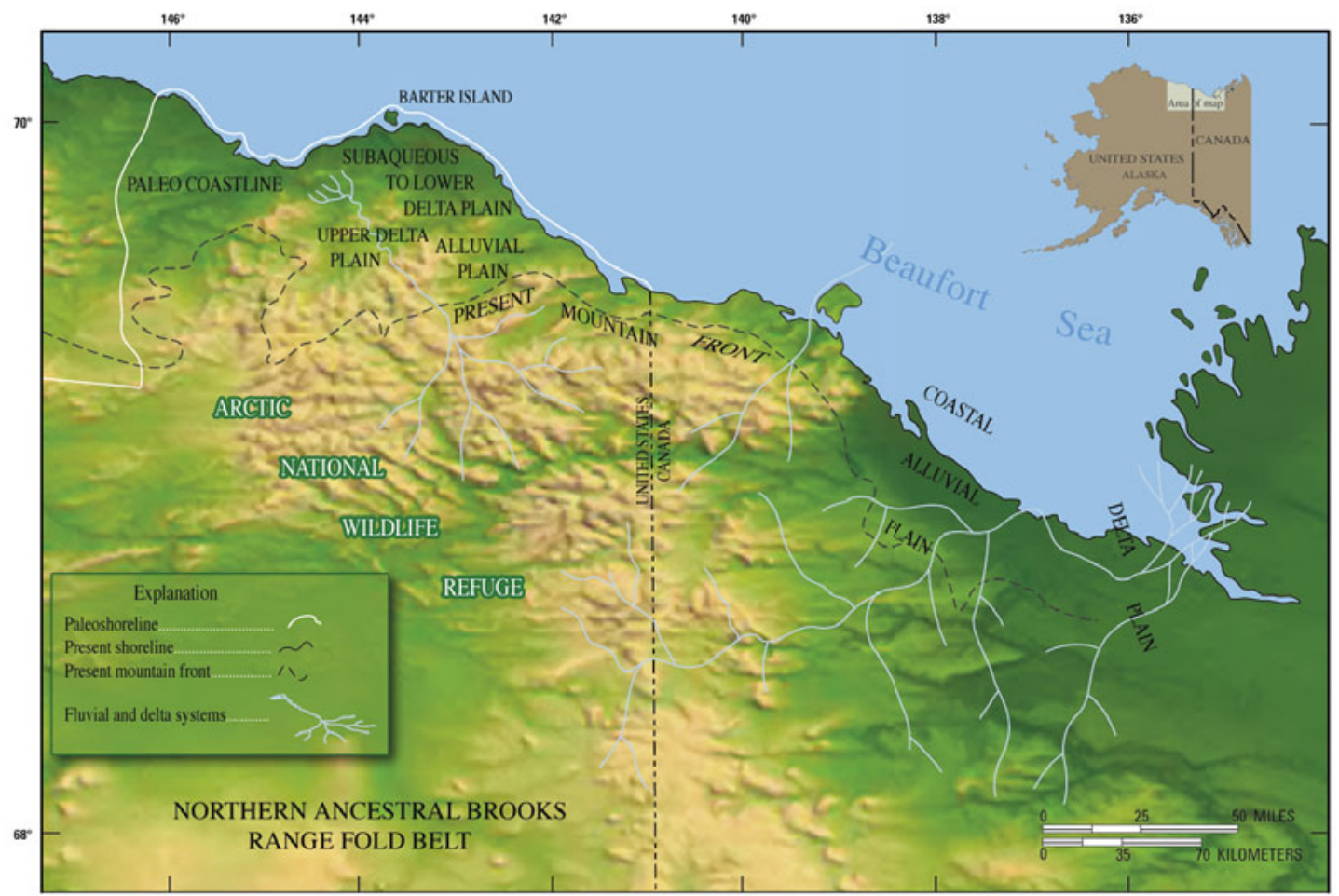

Figure 13. Paleogeographic map showing the depositional environments of the Jago River Formation in the Arctic National Wildlife Refuge area. Modified from Buckingham (1987).

of both deltaic systems blend imperceptibly into one another, and timelines are parallel to their depositional slopes. For example, the delta-front sands of these deltas deposited during the regression cross the sloping timelines and become younger toward the direction of progradation, which is northeastward.

The Cretaceous-Tertiary rocks in the Northern AlaskaSlope coal province include the Jago River and Sagavanirktok Formations (see fig. 6; Gryc and others, 1951; Detterman and others, 1975; Molenaar, 1983; Buckingham, 1987). The Jago River Formation was dated as Late Cretaceous to Paleocene based on pollen and plant fossils (Palmer and others, 1979; Detterman and Spicer, 1981; Buckingham, 1985). The Sagavanirktok Formation was dated as Paleocene to Pliocene (and may possibly be as young as Pleistocene) based on palynomorphs and microfossils (Molenaar and others, 1986). The Sagavanirktok Formation intertongues with the Canning Formation of the Colville Group (Molenaar and others, 1986).

\section{Jago River Formation}

The Jago River Formation, which was named and described by Buckingham (1987), is as much as $9,387 \mathrm{ft}$ $(2,861 \mathrm{~m})$ thick. It consists of conglomerates, sandstones, siltstones, mudstones, carbonaceous shales, and coals. Buckingham (1987) divided the formation into four lithofacies units; from bottom to top these are (1) a delta-plain lithofacies-mainly sandstones and siltstones, as much as $928 \mathrm{ft}$ (282 m) thick; (2) a meandering stream lithofacies (lower part) - mainly sandstones and subordinate conglomerates, siltstones, and coals, as much as 5,526 ft (1,685 m) thick; (3) a braided stream lithofacies - predominantly conglomerates and minor sandstones, as much as 2,228 $\mathrm{ft}(679 \mathrm{~m})$ thick; and (4) a meandering stream lithofacies - mainly carbonaceous shales and minor sandstones conglomerates, as much as $702 \mathrm{ft}$ (214 $\mathrm{m})$ thick. The few coal beds that are in the Jago River Formation are associated with the meandering stream lithofacies and are thin and uneconomic.

The lithofacies of the Jago River Formation indicate that the rocks were deposited in a fluvial-dominated delta that was formed in close proximity to the ancestral Brooks Range (fig. 13). Through time the delta was prograded by a fan delta, which was subsequently replaced by a fluvial-dominated delta. This evolution of fluvio-deltaic systems may have been controlled by tectonism of the ancestral Brooks Range and (or) eustatic sea-level rise and fall. These fluvio-deltaic systems prograded to the north-northwest. Most coal-forming mires are related to these fluvial-dominated deltaic systems.

\section{Sagavanirktok Formation}

The Sagavanirktok Formation consists of a thick sequence of sandstones, siltstones, mudstones, conglomerates, carbonaceous shales, and coals (fig. 14). Thickness is as much as 7,500 ft (2,300 m) (Molenaar and others, 1986). Sandstones are the most abundant lithology (fig. 15). The formation is a generally coarsening-upward sequence with the lower part dominated by shaley tongues of the Canning Formation (Molenaar and others, 1986). There are at least three 


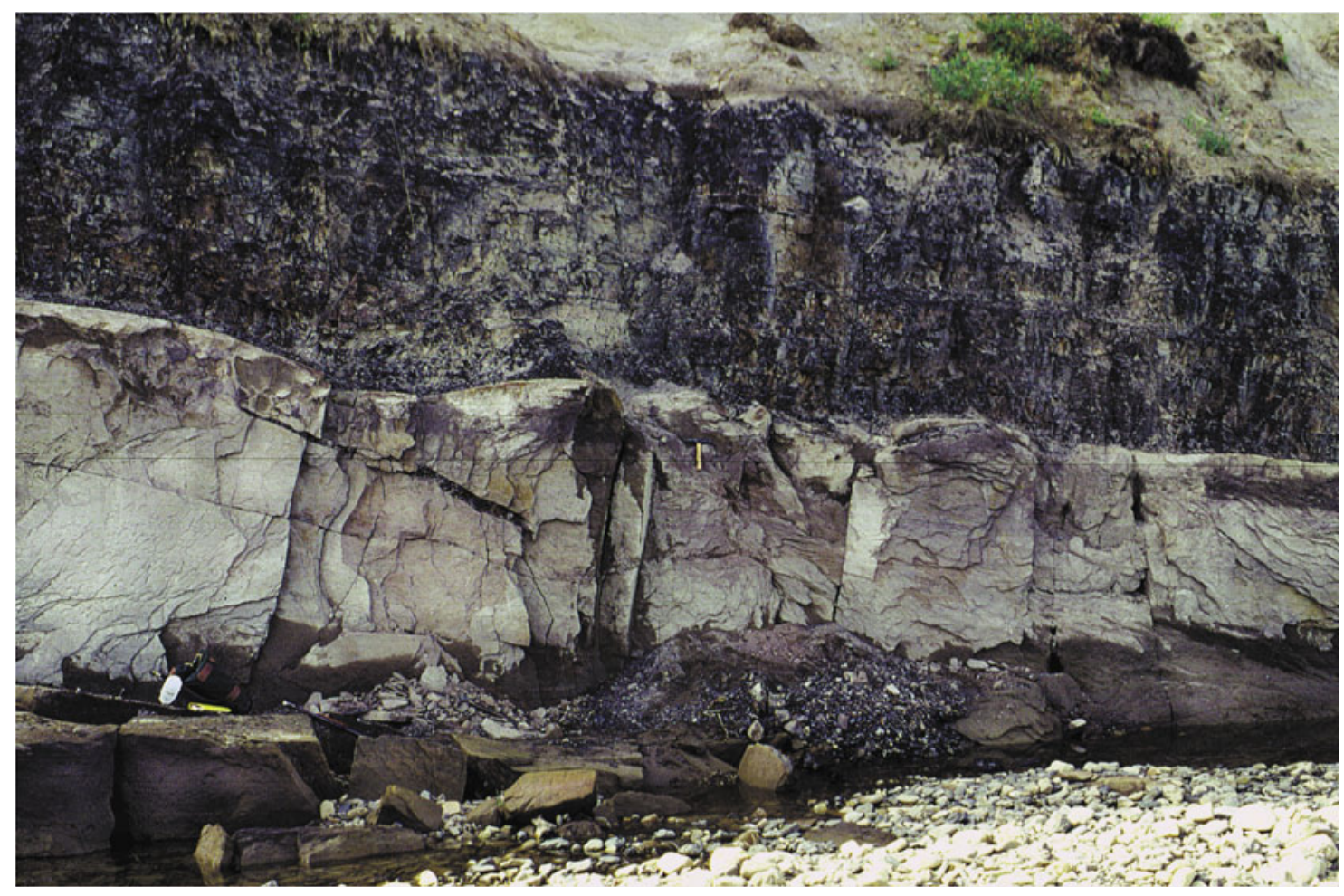

Figure 14. Photograph of a coal bed underlain by a sandstone in the Sagavanirktok Formation. Photograph courtesy of S.B. Roberts. Hammer on the sandstone is 1 foot long for scale.

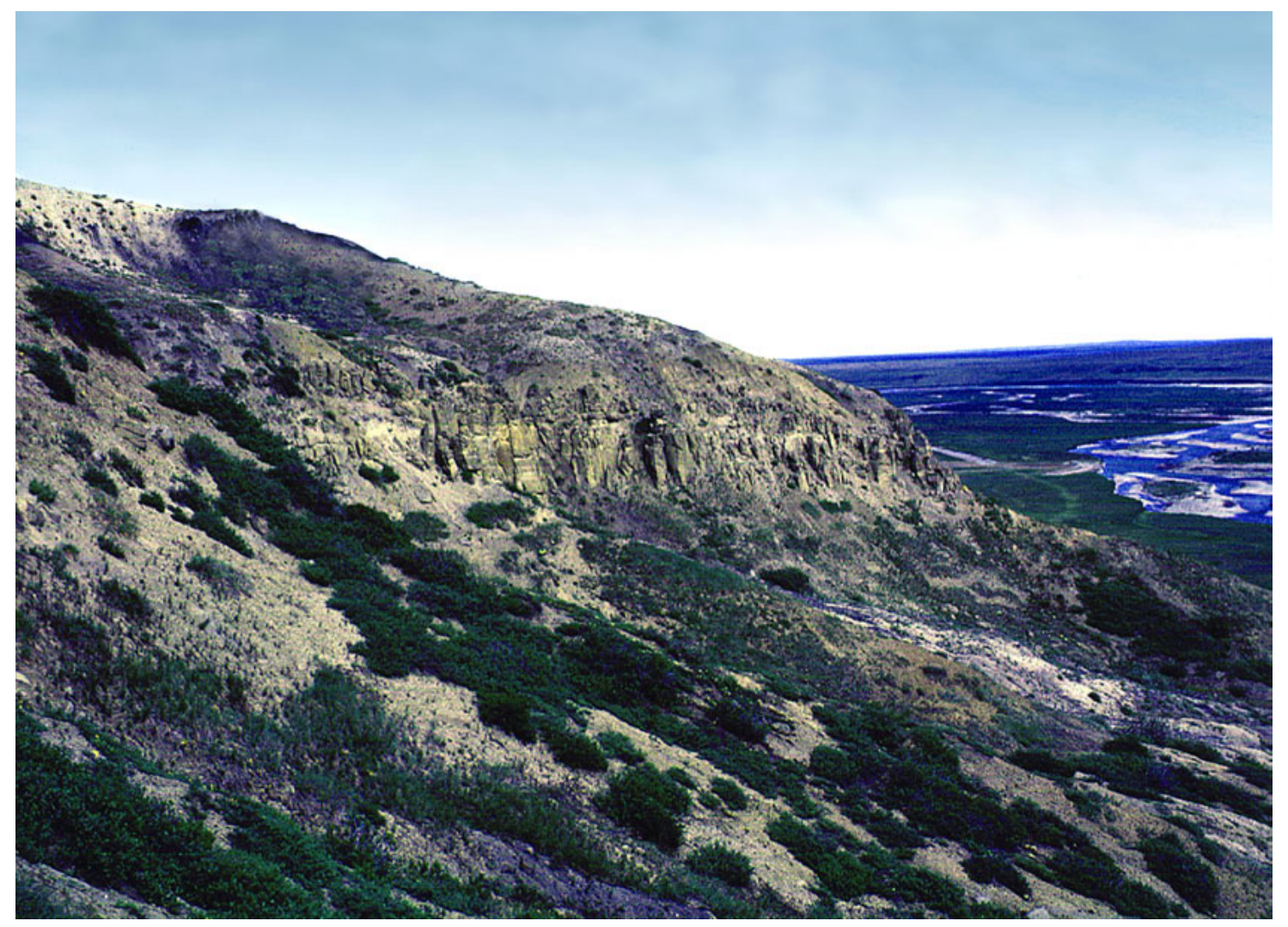

Figure 15. Photograph of fluvial-channel sandstone and associated rocks in the Sagavanirktok Formation. Photograph courtesy of S.B. Roberts. 


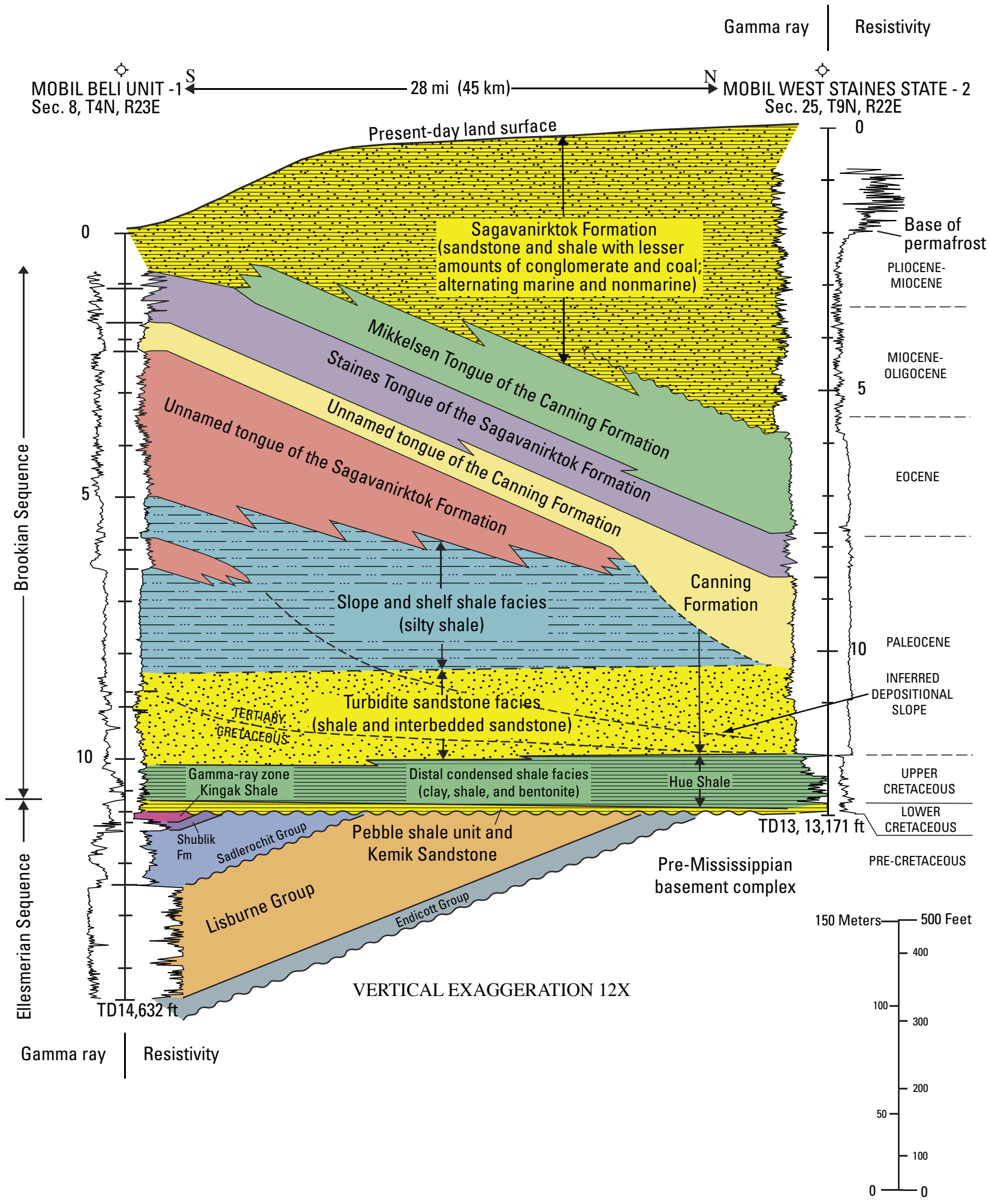

Figure 16. Stratigraphic cross section of the Tertiary Brookian sequence in the eastern part of the National Petroleum Reserve Alaska. Modified from Molenaar and others (1985). 


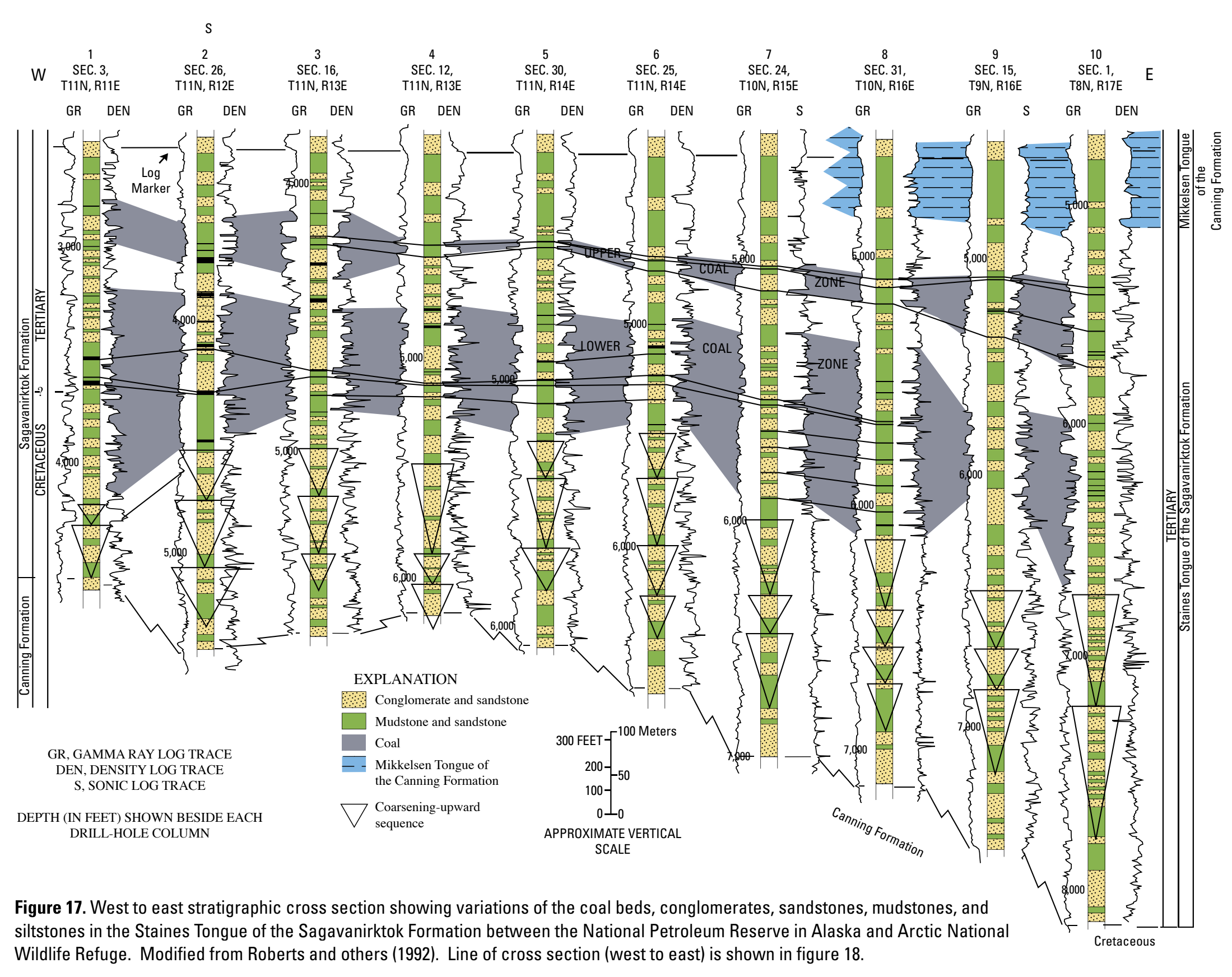



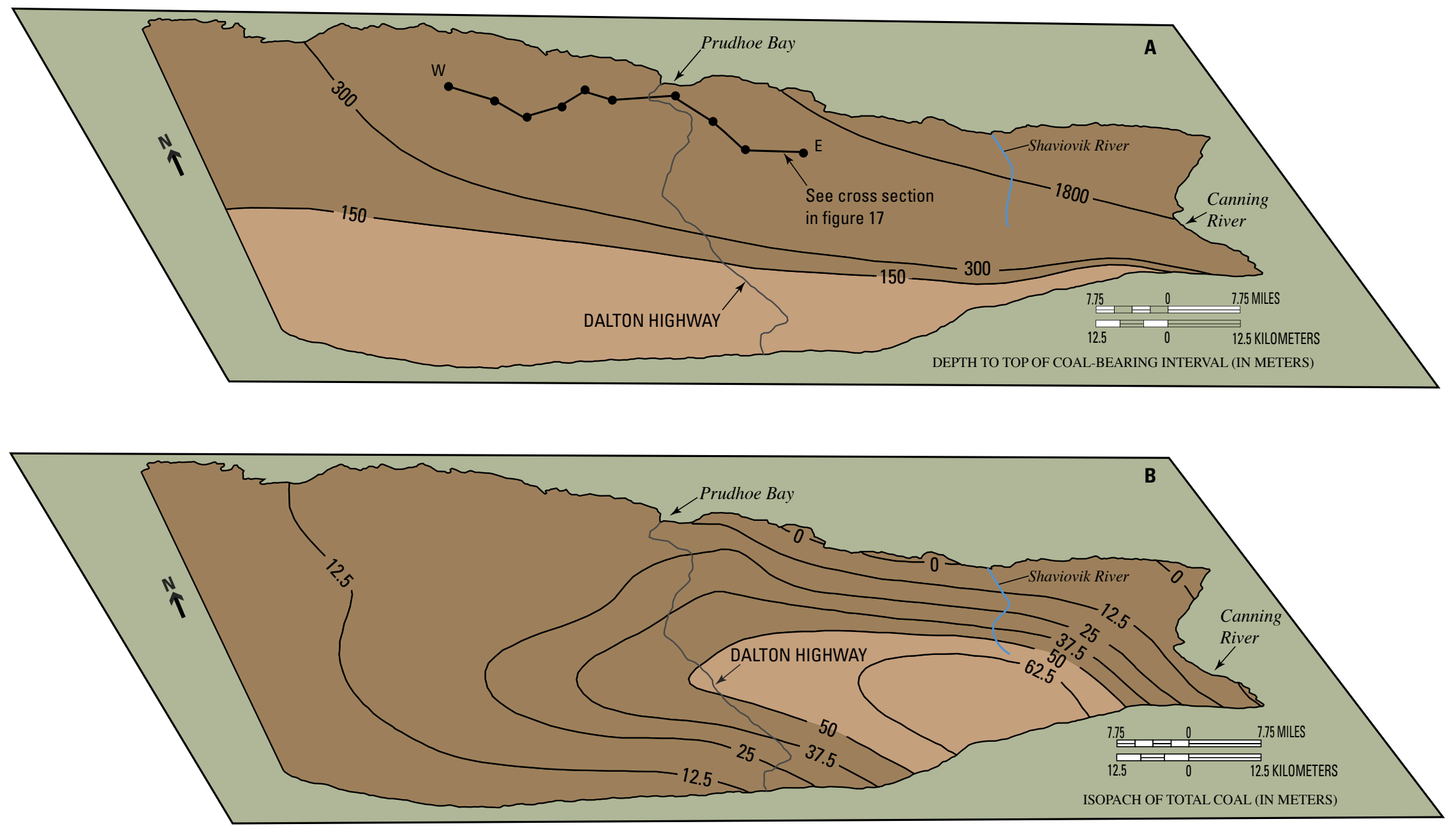

Figure 18. Maps showing the (A) depth to top of coal-bearing interval and (B) net coal thickness isopach of the Staines Tongue of the Sagavanirktok Formation. Modified from Roberts and others (1992). 
Sagavanirktok tongues that intercalate with the Canning shales (fig. 16). The uppermost tongue identified by Molenaar and others (1986) as the Staines Tongue was studied by Roberts (1991) and Roberts and others (1992) and varies from 650 to $2,950 \mathrm{ft}(200$ to $900 \mathrm{~m})$ in thickness (fig. 17). The lower 330 to $1,640 \mathrm{ft}$ ( 100 to $500 \mathrm{~m}$ ), of the Staines Tongue is dominated by coarsening-upward mudstone, siltstone, and sandstone representing parasequence sets. These parasequence sets are overlain by two coal-bearing intervals - the lower and upper coal zones in the middle part of the tongue (Roberts and others, 1992) - that are separated by interbedded sandstones and mudstones, which are as much as $295 \mathrm{ft}$ (90 m) thick. The lower coal zone is as thick as $850 \mathrm{ft}(260 \mathrm{~m})$ and contains 12 coal beds. The upper coal zone is as thick as $360 \mathrm{ft}(110 \mathrm{~m})$ and contains seven coal beds. The individual coal beds are as much as $23 \mathrm{ft}(7.1 \mathrm{~m})$ thick. The uppermost part of the Staines Tongue is interbedded sandstone and mudstones and is as much as $260 \mathrm{ft}(80 \mathrm{~m})$ thick. This interval is, in turn, overlain by mudstones of the Mikkelsen Tongue of the Canning Formation. Coal beds are distributed over an area of 5,790 $\mathrm{mi}^{2}$ $\left(15,000 \mathrm{~km}^{2}\right)$. Near Prudhoe Bay, a coal-bearing interval as much as $1,310 \mathrm{ft}(400 \mathrm{~m})$ thick contains coal beds $1.9-22 \mathrm{ft}$ (0.6-6.7 m) thick (Roberts, 1991); one 6.5-ft-thick (2 m) coal zone has been reported on the lower Shaviovik River (fig. 18; Roberts and others, 1992). Lignite and coaly shale as thick as $19 \mathrm{ft}(6 \mathrm{~m})$ occur in the lowermost part of the formation (Detterman and others, 1975; Molenaar and others, 1984).

The Sagavanirktok Formation represents the final infilling of the Colville Basin in the eastern part of the Northern Alaska-Slope coal province. The Staines Tongue represents an episode of this infilling by the deposition of fluvio-deltaic sediments. The lower part of the Staines Tongue is dominated by parasequence sets representing delta front-prodelta deposits, which grade into the shelf-slope mudstones of the Canning Formation (figs. 17 and 18). The lower coal zone was deposited in an alluvial-delta plain in which the coal beds accumulated in interfluvial and interdistributary mires. The noncoaly interval between the two coal zones reflects a landward advance of the paleoshoreline resulting from a minor transgression or sea-level rise. The coal beds of the upper coal zone were probably formed in lower delta-plain and back-barrier mires as the paleoshoreline then regressed. The thin nature of the upper coal zone (fig. 17) and the sandy character of the uppermost part of the Sagavanirktok, which is in turn overlain by the Mikkelsen mudstone tongue of the Canning Formation, indicate a back-stepping paleoshoreline. In this setting, rapid transgression over the peat-forming mires reworked older deposits, probably forming barrier-shoreface deposits prior to a marine flood.

The thick and laterally extensive coal beds of the lower coal zone of the Staines Tongue probably reflect a peat accumulation in mires formed during a time of paleoshoreline stability. This event may correspond to a regressive maximum that led to vertical stacking of paleoshoreline deposits, closely similar to that described for the Nanushuk Group. However, unlike the Nanushuk Group, the Staines Tongue of the
Sagavanirktok Formation was affected by sea-level fluctuations prior to the maximum transgression that deposited the overlying Mikkelsen Tongue of the Canning Formation. Sea-level fluctuations and marine flooding interrupted coal-forming mires, which provided only a brief period of time for peat accumulation.

\section{Coal Resource Assessment of the Northern Alaska-Slope Coal Province}

The coal resource assessments of different workers in the Northern Alaska-Slope coal province vary greatly in magnitude and coal resource categories, resulting in confused reporting of estimates. As a result we reconstructed these different coal resource estimates following guidelines of the coal-resource classification system of Wood and others (1983). This new reporting system of the coal resources of Alaska in general, and of Northern Alaska-Slope coal province in particular, as modified from previous estimates, is summarized in table 1. Following is a historical account of the various coal resource assessments in the coal province.

\section{Cretaceous Rocks}

In an early resource assessment of Cretaceous rocks in the Northern Alaska-Slope coal province, Barnes (1967a) calculated a total of $2.4 \times 10^{9}$ short tons $\left(2.2 \times 10^{9}\right.$ metric tons $)$ of demonstrated coal resources and $117 \times 10^{9}$ short tons $(107 \times$ $10^{9}$ metric tons) of undiscovered (hypothetical) coal resources. Later Tailleur and Brosgé (1976) estimated the coal resources in the coal province by calculating the product of coal-bearing area and coal concentration. Using surface data and two oil and gas test wells, these workers estimated the coal resources in the Northern Alaska-Slope coal province at $120 \times 10^{9}$ short tons $\left(109 \times 10^{9}\right.$ metric tons $)$ of identified coal resources plus $114 \times 10^{9}$ to $37 \times 10^{12}$ short tons $\left(104 \times 10^{9}\right.$ to $34 \times 10^{12}$ metric tons) of hypothetical coal resources (see table 1 ).

Later, Sable and Stricker (1987), using all available data for the Nanushuk Group, estimated coal resources for the National Petroleum Reserve in the Alaska portion of the North Slope. Using the methodology described by Wood and others (1983) and all available data for the area of the known Nanushuk Group coal-bearing rocks, Sable and Stricker (1987) estimated the hypothetical coal resources for the Nanushuk Group on the North Slope, which are shown in table 2. In summary, there are 1.3 trillion short tons (1.2 trillion metric tons) of subbituminous coal and 1.9 trillion short tons (1.7 trillion metric tons) of bituminous coal, for a total of 3.2 trillion short tons (2.9 trillion metric tons) of hypothetical coal resources for the Nanushuk Group on the North Slope of Alaska (table 2). Barnes (1967a) estimated about 101 billion short tons ( 92 billion metric tons) of identified coal resources in this group of rocks. 
Stricker (1991) indicated that the Nanushuk Group contains an estimated $3.1 \times 10^{12}$ short tons $\left(2.9 \times 10^{12}\right.$ metric tons) of hypothetical coal resources for onshore northern Alaska (table 2); of this total, $1.3 \times 10^{12}$ short tons $\left(1.2 \times 10^{12}\right.$ metric tons) is subbituminous, and $1.9 \times 10^{12}$ short tons $(1.7 \times$ $10^{12}$ metric tons) is bituminous (Stricker, 1983, 1991). In-situ speculative Cretaceous Nanushuk coal that lies under the Chukchi Sea has been estimated at $2.0 \times 10^{12}$ short tons $(1.8$ $\times 10^{12}$ metric tons) of lignite A to high-volatile bituminous A coal (Affolter and Stricker, 1987b).

\section{Coal Quality}

The coal beds of the Nanushuk Group in the Northern Alaska-Slope coal province range in apparent rank from lignite A to high volatile A bituminous coal with a mean of high-

Table 2. Estimates of hypothetical coal resources for the Cretaceous Nanushuk Group (Stricker, 1991) and Tertiary Staines Tongue of the Sagavanirktok Formation (Roberts and others, 1992) in the Northern Alaska-Slope coal province.

$[>$, greater than]

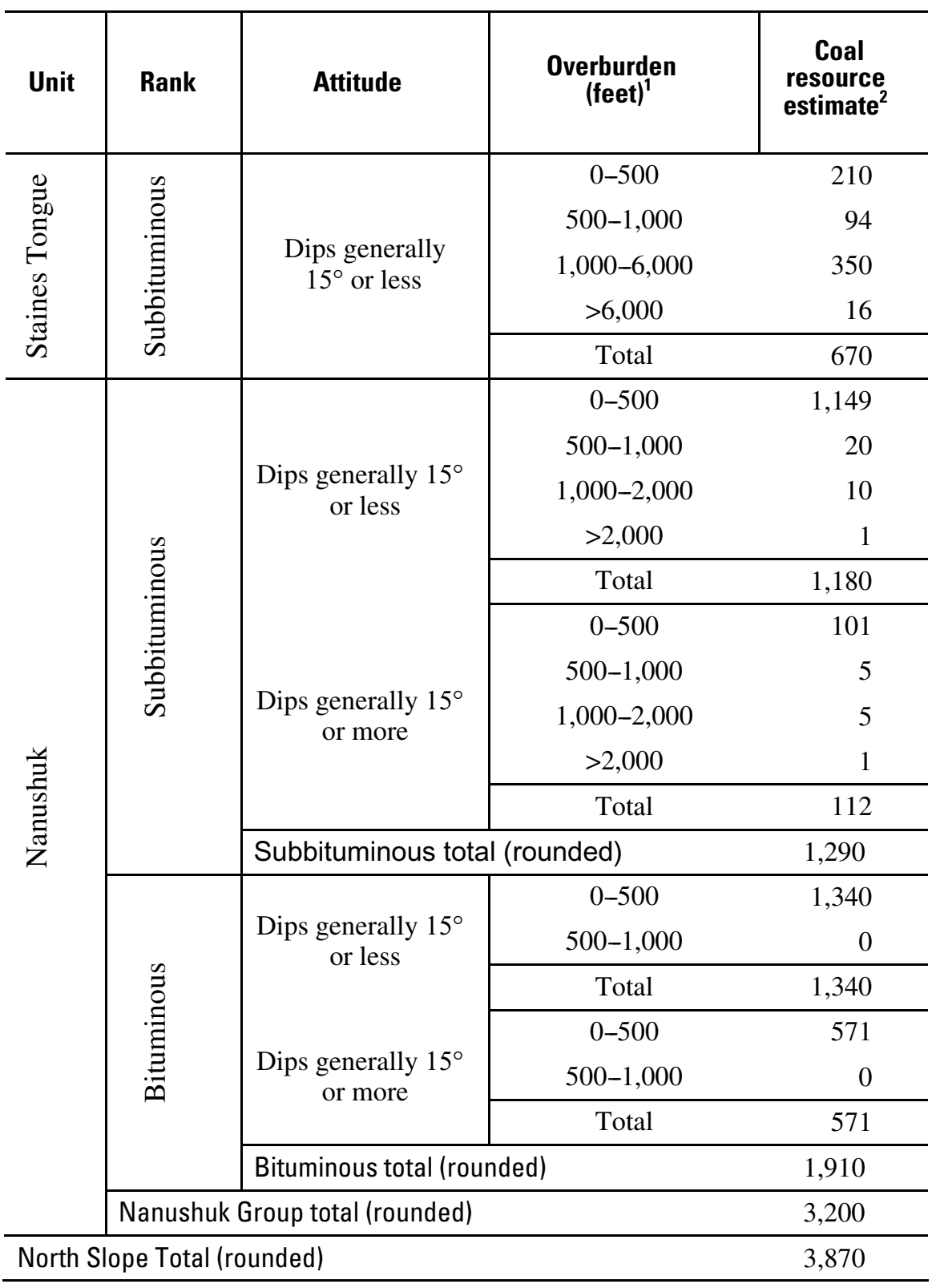


volatile $\mathrm{C}$ bituminous coal (table $3 \mathrm{a}$ ). The heating values range from 9,100 to $12,700 \mathrm{Btu} / \mathrm{lb}$ (5,050 to 7,060 kilocalories/kilogram) with an average of 12,300 Btu/lb (6,830 kilocalories/ kilogram) (State of Alaska, 1993). Total sulfur content ranges from 0.1 to 2.0 percent with a mean of 0.3 percent. The ash yield has a mean of 11.0 percent (Affolter and Stricker, 1987a). The coal is generally subbituminous A under the Arctic coastal plain and high-volatile bituminous in the folded foothills, is low in ash (less than 10 percent) and sulfur (1.4 percent) (Sanders, 1981; Affolter and Stricker, 1987a), and has low concentrations of elements of environmental concern (As, $\mathrm{Be}, \mathrm{Hg}, \mathrm{Mo}, \mathrm{Sb}$, and Se) (Affolter and Stricker, 1987a). The higher rank coal beds in the foothills are probably upgraded in apparent rank by tectonism.

\section{Tertiary Rocks}

Early resource assessment of the coal resources of the Sagavanirktok Formation by Sanders (1976) and Tailleur and Brosgé (1976) estimated 50-60 billion short tons (45-55 billion metric tons) of hypothetical resources. Evaluation of 48 geophysical logs penetrating coal beds of the formation led Roberts and others (1992) to estimate a hypothetical coal resource of 670 billion short tons (610 billion metric tons) (table 2), which is 10 times more than the original estimate. The coal included in the estimate by Roberts and others (1992) occurs mainly in the onshore Northern Alaska-Slope coal province, where the overburden varies from 150 to $1,800 \mathrm{ft}$ (46 to $550 \mathrm{~m}$ ). As shown in figure 17, the thickest coal is in the southeast part of the coal province. Affolter and Stricker (1987b) estimated the offshore (beneath the Beaufort Sea) hypothetical resources to be 300 billion short tons (270 billion metric tons).

\begin{tabular}{|c|c|c|c|c|c|c|}
\hline \multirow{2}{*}{ Unit } & \multirow{2}{*}{ Parameter } & \multirow{2}{*}{$\begin{array}{c}\text { Number } \\
\text { of } \\
\text { samples }\end{array}$} & \multicolumn{2}{|c|}{ Range } & \multirow{2}{*}{$\begin{array}{c}\text { Arithmetic } \\
\text { mean }\end{array}$} & \multirow{2}{*}{$\begin{array}{l}\text { Standard } \\
\text { deviation }\end{array}$} \\
\hline & & & Minimum & Maximum & & \\
\hline \multirow{20}{*}{ 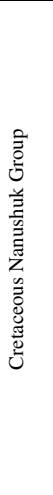 } & \multicolumn{6}{|c|}{ Proximate and ultimate analysis } \\
\hline & Moisture & 68 & 1.80 & 33.10 & 12.52 & 7.12 \\
\hline & Volatile matter & 68 & 22.10 & 40.00 & 30.07 & 3.82 \\
\hline & Fixed carbon & 68 & 24.50 & 60.20 & 47.13 & 7.87 \\
\hline & Ash yield & 68 & 2.30 & 37.20 & 10.28 & 7.82 \\
\hline & Hydrogen & 52 & 3.82 & 6.25 & 5.24 & 0.48 \\
\hline & Carbon & 52 & 43.92 & 72.50 & 60.96 & 8.54 \\
\hline & Nitrogen & 52 & 0.72 & 1.85 & 1.29 & 0.30 \\
\hline & Oxygen & 52 & 11.30 & 39.33 & 23.73 & 6.58 \\
\hline & Sulfur & 73 & 0.10 & 2.00 & 0.31 & 0.23 \\
\hline & \multicolumn{6}{|c|}{ Calorific value } \\
\hline & Btu per pound & 68 & 5,610 & 13,820 & 10,140 & 1,810 \\
\hline & \multicolumn{6}{|c|}{ Forms-of-sulfur } \\
\hline & Sulfate & 37 & $0.01 \mathrm{~L}$ & 0.04 & 0.01 & 0.01 \\
\hline & Pyritic & 37 & $0.01 \mathrm{~L}$ & 0.06 & 0.01 & 0.01 \\
\hline & Organic & 37 & $0.01 \mathrm{~L}$ & 0.55 & 0.28 & 0.12 \\
\hline & \multicolumn{6}{|c|}{ Ash-fusion-temperatures ${ }^{\circ} \mathrm{F}$} \\
\hline & Initial deformation & 51 & 2,180 & $2,910 \mathrm{G}$ & 5,540 & 200 \\
\hline & Softening temperature & 51 & 2,130 & $2,910 \mathrm{G}$ & 2,410 & 200 \\
\hline & Fluid temperature & 51 & 2,030 & $2,910 \mathrm{G}$ & 2,300 & 200 \\
\hline
\end{tabular}

\section{Coal Quality}

A summary of chemical analyses of 55 coal outcrop samples from the Sagavanirktok Formation, as reported by Roberts and others (1992), indicated that the apparent rank of the coal beds ranges from lignite A to subbituminous B coal (3,340-9,740 Btu/lb) (1,860-5,410 kilocalories/kilogram), with a mean of subbituminous $\mathrm{C}$ coal $(7,780 \mathrm{Btu} / \mathrm{lb})(4,320$ kilocalories/kilogram) (table 3b). Total sulfur content is low, varying from 0.08 to 2.16 percent with a mean of 0.38 percent. The ash yield varies from 1.2 to 47.1 percent with mean of 11.1 percent. Moisture content ranges from 16.2 to 33 percent with mean of 23.6 percent.

\section{Coal Petrology}

The petrology of the coal beds in the Corwin Formation of the Nanushuk Group was studied by Rao (1980) in the Cape Beaufort region. Forty-eight samples from 14 coal beds showed that the coal is composed mainly of the macerals vitrinite (huminite), liptinite, and inertinite. The percentage of vitrinite varies from 47.1 to 89.5 (average of 74.4), that of liptinite from 0.4 to 10.4 (average of 2.3), and that of inertinite from 1.8 to 33.9 (average of 23.3). The macerals vary from coal bed to coal bed as well as within a coal bed. Many of the beds are high in inertinites (such as fusinite and semifusinite) (charcoals), the proportions of which are lowest at the bottom of the coal bed and increase toward the top. This pattern indicates that mires evolved into a drier setting during accumulation of peat deposits, which promoted forest fires that created the charcoals (fusinites). This interpretation is supported by Spicer (1987), whose investigation indicated seasonality of the generally humid climate during the development of the peatforming mires. Platanoid-like leaves are closely associated with fluvial deposits, and gymnosperm and magnoliid-like

\begin{tabular}{|c|c|c|c|c|c|c|}
\hline \multirow{2}{*}{ Unit } & \multirow{2}{*}{ Parameter } & \multirow{2}{*}{$\begin{array}{c}\text { Number } \\
\text { of } \\
\text { samples }\end{array}$} & \multicolumn{2}{|c|}{ Range } & \multirow{2}{*}{$\begin{array}{c}\text { Arithmetic } \\
\text { mean }\end{array}$} & \multirow{2}{*}{$\begin{array}{l}\text { Standard } \\
\text { deviation }\end{array}$} \\
\hline & & & Minimum & Maximum & & \\
\hline \multirow{2}{*}{.0ี } & \multicolumn{6}{|c|}{ Proximate and ultimate analysis } \\
\hline & Moisture & 68 & 18.44 & 35.97 & 27.04 & 3.85 \\
\hline \multirow{8}{*}{ 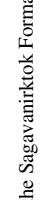 } & Volatile matter & 68 & 23.78 & 36.09 & 30.16 & 2.73 \\
\hline & Fixed carbon & 68 & 25.05 & 42.35 & 34.65 & 4.35 \\
\hline & Ash yield & 68 & 1.16 & 25.46 & 8.15 & 6.24 \\
\hline & Hydrogen & 68 & 5.11 & 7.12 & 6.19 & 0.42 \\
\hline & Carbon & 68 & 35.07 & 55.11 & 46.22 & 4.94 \\
\hline & Nitrogen & 62 & 0.59 & 1.70 & 1.04 & 0.22 \\
\hline & Oxygen & 68 & 30.09 & 49.21 & 38.16 & 3.86 \\
\hline & Sulfur & 160 & 0.06 & 1.65 & 0.31 & 0.33 \\
\hline ت्ञ & \multicolumn{6}{|c|}{ Calorific value } \\
\hline \multirow{6}{*}{ 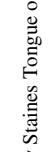 } & Btu per pound & 68 & 5,930 & 9,330 & 7,770 & 860 \\
\hline & \multicolumn{6}{|c|}{ Forms-of-sulfur } \\
\hline & Sulfate & 160 & $0.01 \mathrm{~L}$ & 0.23 & 0.03 & 0.03 \\
\hline & Pyritic & 160 & $0.01 \mathrm{~L}$ & 0.24 & 0.03 & 0.03 \\
\hline & Organic & 160 & $0.01 \mathrm{~L}$ & 1.54 & 0.26 & 0.31 \\
\hline & \multicolumn{6}{|c|}{ Ash-fusion-temperatures ${ }^{\circ} \mathrm{F}$} \\
\hline \multirow{3}{*}{ 苞 } & Initial deformation & 69 & 2,070 & $2,800 \mathrm{G}$ & 2,460 & 240 \\
\hline & Softening temperature & 69 & 1,930 & $2,800 \mathrm{G}$ & 2,360 & 240 \\
\hline & Fluid temperature & 69 & 1,890 & $2,800 \mathrm{G}$ & 2,240 & 230 \\
\hline
\end{tabular}


leaves are associated with lacustrine and mire deposits (Spicer, 1987). Vitrinite reflectance values of the 14 coal beds vary from 0.65 to 0.74 (average 0.70 ) percent.

\section{Central Alaska-Nenana Coal Province}

The Central Alaska-Nenana coal province (fig. 1) is the smallest, most centrally located, and most thoroughly studied of the coal provinces on the north side of the Alaska Range. It has accounted for more than one-half of the coal mined in Alaska and is the only province in Alaska being currently mined. This coal province is in the northern foothills of the Alaska Range, extending from about $50 \mathrm{mi}(80 \mathrm{~km})$ west to 50 mi $(80 \mathrm{~km}$ ) east of the Alaska Railroad (see fig 1). It consists of several synclinal basins partly or wholly detached from each other by erosion of coal-bearing rocks from intervening structural highs. These coal-bearing synclinal basins were recognized as coalfields and include the Jarvis Creek, East Delta, West Delta, Wood River, Mystic Creek, Tatlanika Creek, Lignite Creek, Healy Creek, Rex Creek, and Western Nenana. They extend as a discontinuous belt from $9 \mathrm{mi}(14.5 \mathrm{~km})$ wide to $56 \mathrm{mi}(90 \mathrm{~km}$ ) long (fig. 19).
The Healy Creek, Lignite, and Suntrana coalfields, where past mining occurred and most current mining occurs lie along the Alaska Railroad and the Anchorage to Fairbanks highway (see fig. 1; George Parks State Highway 1). The railroad provided the needed transportation for marketing the coal. In 1918, underground coal mining by the Healy River Coal Corporation began at Suntrana, $4 \mathrm{mi}(6.4 \mathrm{~km})$ east of the confluence of Healy Creek and the Nenana River (Usibelli, 1986). Horse-drawn sleds to the railroad camp in Healy originally transported coal until a railroad spur was built to the mine in 1922. The Healy River coal mine accounted for one-half of the State's production from 1920 to 1940. The rest of the production was from the Evan Jones mine in the Matanuska coalfield (see discussion of the Southern Alaska-Cook Inlet coal province).

The military buildup in Alaska in the 1940s and after World War II provided a new market for coal that resulted in opening more mines to meet the demand (Usibelli, 1986). Usibelli Coal Mine, Inc. (UCM), opened the first strip mine in the coal province east of Suntrana in 1943. In 1961, UCM purchased the Healy River Coal Corporation and continued mining underground. The Arctic Coal Company opened a small mine on Lignite Creek and operated it until 1963. The Vitro Mineral Mine was opened in 1963 east of Suntrana and

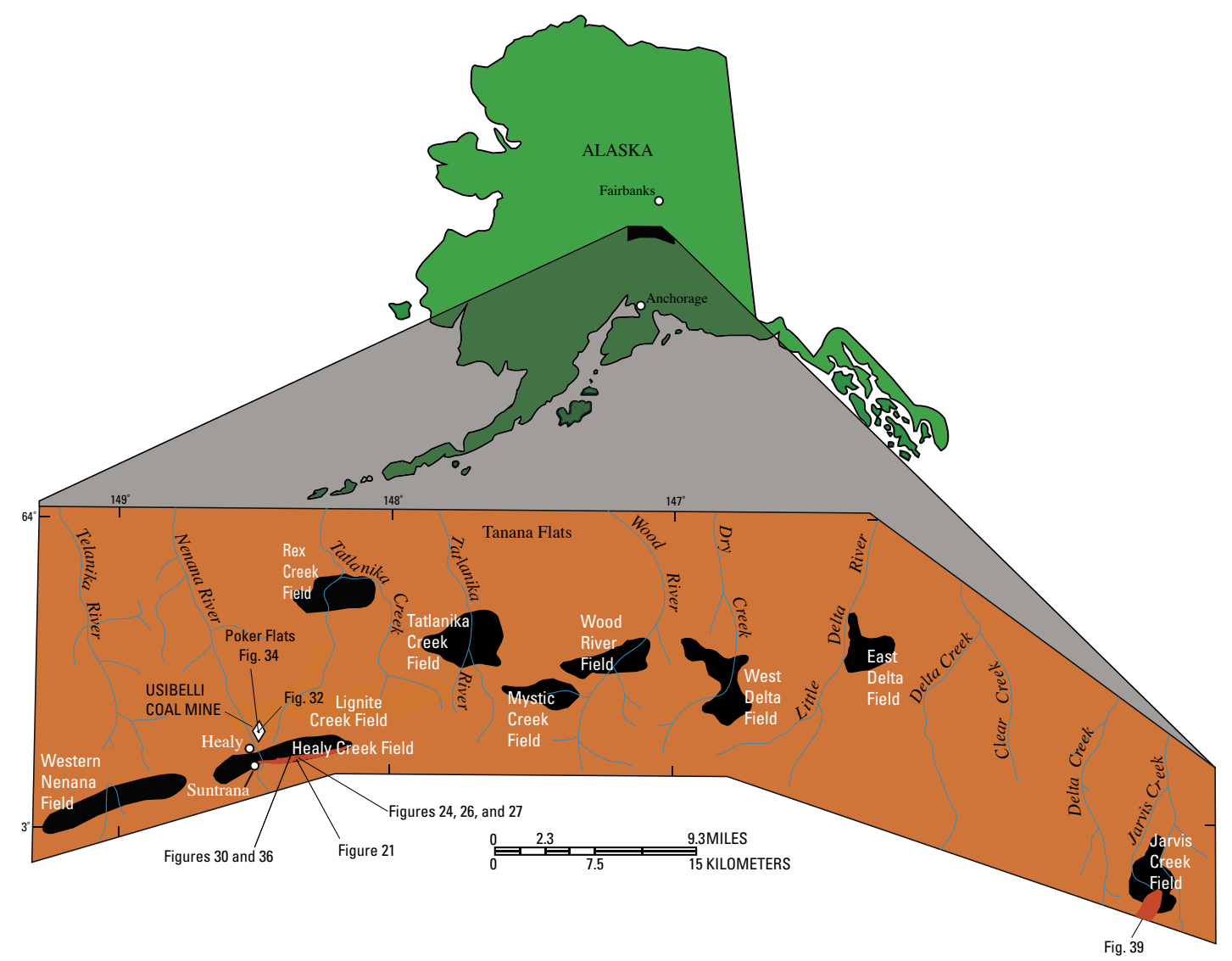

Figure 19. Map showing the coalfields in the Central Alaska-Nenana coal province. 
in 1970 was purchased by UCM. Golden Valley Electric Association opened a mine-mouth powerplant at Healy in 1968. Since that time UCM has supplied coal to the powerplant and in 1985 entered the international market by supplying coal to South Korea. UCM is the only active coal mine in the State today.

\section{Tertiary Usibelli Group}

The Usibelli Group (Wahrhaftig, 1987), a nonmarine sedimentary sequence of Tertiary age, consists, from bottom to top, of the coal-bearing Healy Creek, noncoaly Sanctuary, coal-bearing Suntrana and Lignite Creek Formations and noncoaly Grubstake Formation (fig. 20). It is overlain unconformably by the Nenana Gravel. Detailed discussions of the group are summarized from Wahrhaftig and others (1969), Wahrhaftig (1987), Wahrhaftig and others (1994), and Stanley and others (1992). Sanders (1976) recognized as many as 30 coal beds in the Usibelli Group, which are mainly $2.5 \mathrm{ft}(0.7$ $\mathrm{m})$ thick but can be as much as $30 \mathrm{ft}(9.1 \mathrm{~m})$ thick. The vertical and lateral stratigraphic variations of the Healy Creek, Sanctuary, and Suntrana Formations, which overlie the lower Paleozoic and Precambrian (?) pelitic and quartzose schist sequence (Csejety and others, 1992), are displayed in figure 21.
The depositional environments of the Usibelli Group have been interpreted as fluvial and lacustrine deposits (Buffler and Tripplehorn, 1976; Selleck and Panuska, 1983; Merritt, 1986; Stanley and others, 1992; Wahrhaftig and others, 1994). Flores and Stanley (1995) proposed that the Healy Creek Formation was deposited in an incised paleovalley infilled by sediments of transverse alluvial fans and longitudinal braided streams that flowed southward (fig. 22A-D). The paleocurrent directions from crossbeds in the sandstones of the Healy Creek, Suntrana, and Lignite Creek Formations (fig. 23 ) indicate southward flow of streams. Inactive braid-belt deposits formed platforms for raised mires on which thin to thick peat deposits accumulated. Lacustrine sediments of the Sanctuary Formation succeeded these alluvial environments being deposited in a lake that resulted from coalescing of flood-plain lakes and fluvial channels caused by damming of the downstream extent of the ancestral fluvial system, which flowed southward into the ancestral Cook Inlet Basin. Either uplift of the Alaskan Range or movement along the Denali fault may have caused damming. This tectonic movement caused base level to rise (Flores and Stanley (1995). The lake was filled by alluvial fan deltas, which gradually lowered base level and restored the fluvial systems that continued to flow southward. This led to formation of low-sinuosity streams

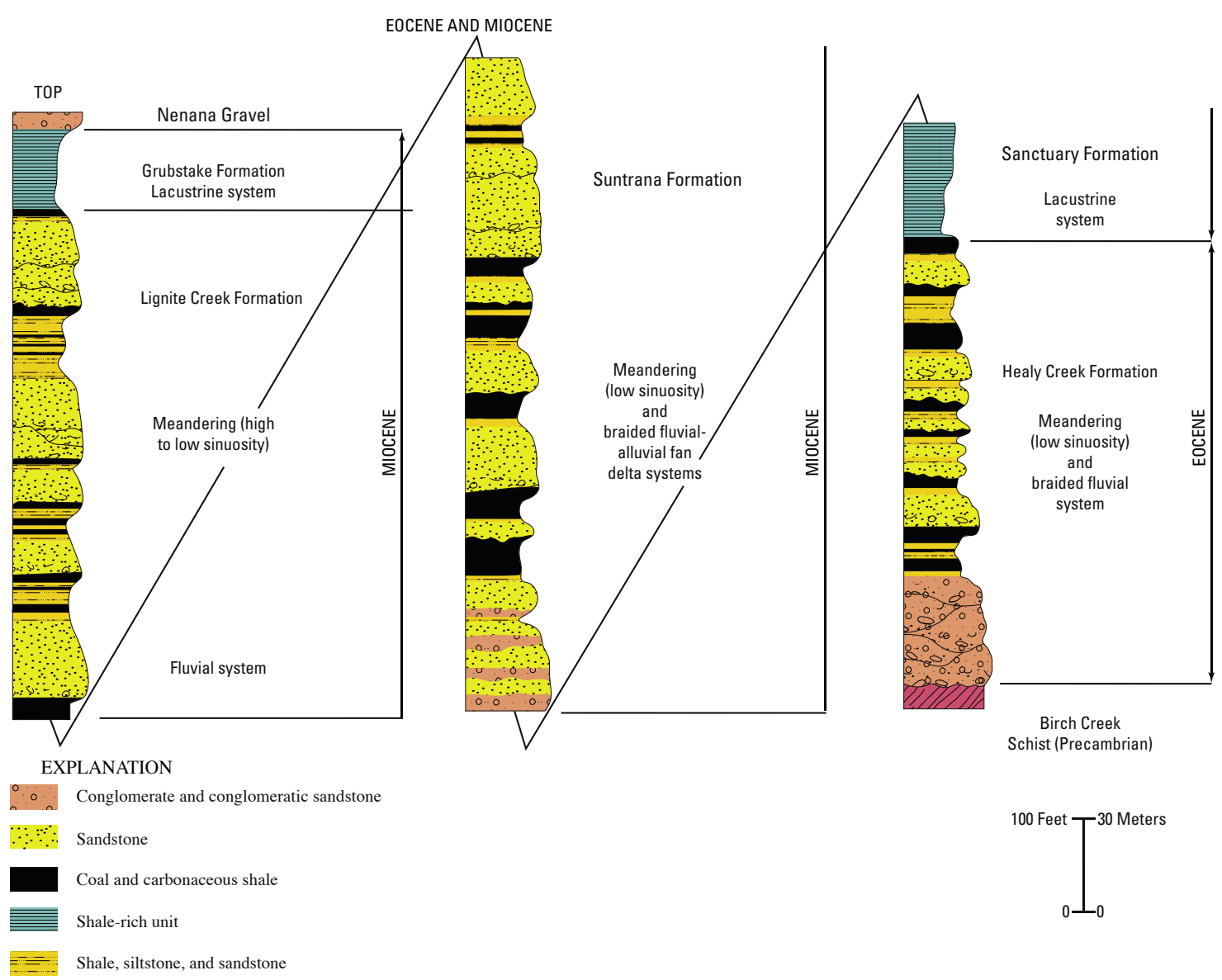

Figure 20. Generalized stratigraphic and lithofacies column of the Usibelli Group in the Central Alaska-Nenana coal province. 


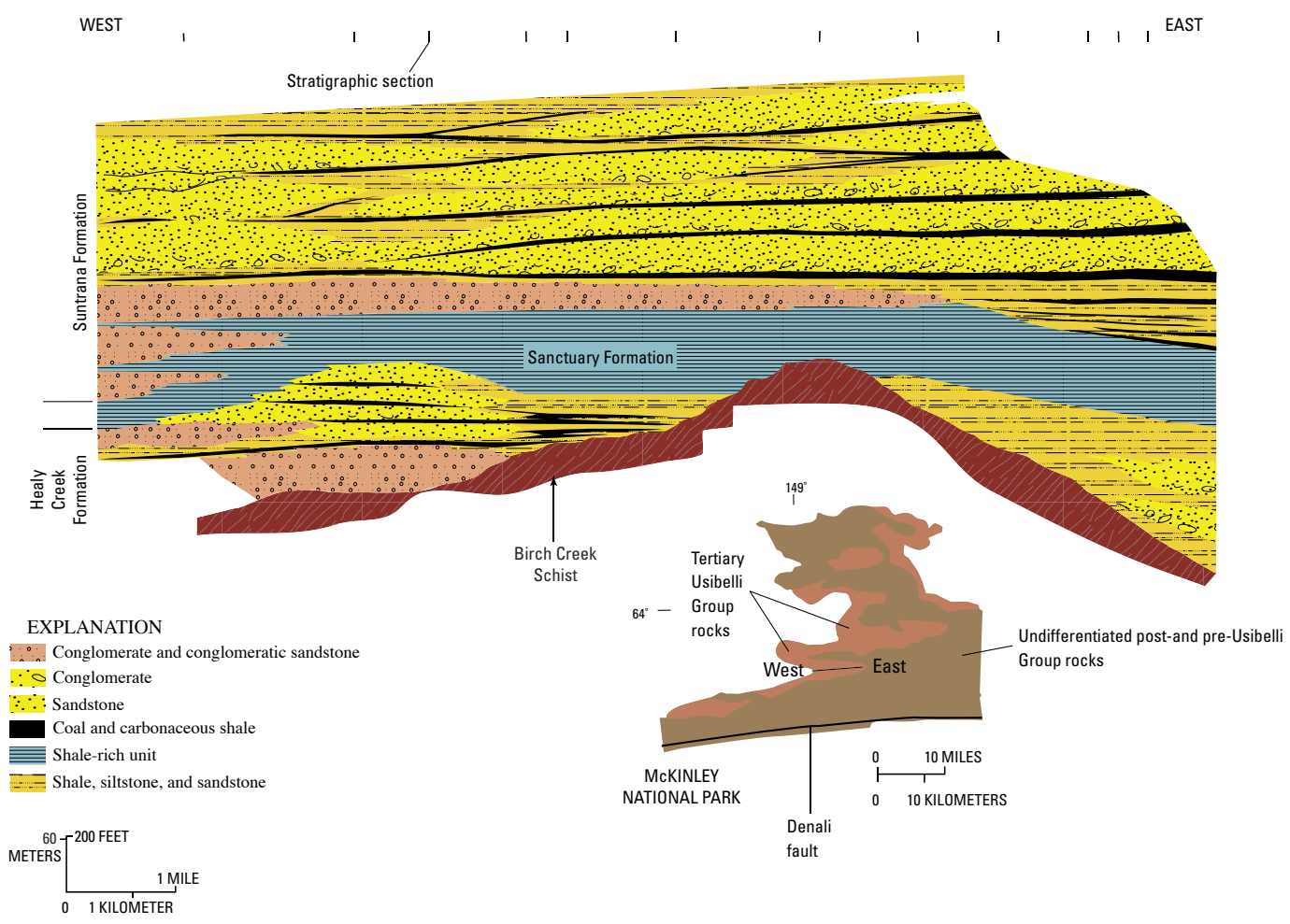

Figure 21. Stratigraphic cross section showing the variations of the conglomerates, sandstones, siltstones, mudstones, and coal beds in the lower part of the Usibelli Group in the Healy Creek coalfield on the southern part of the Central Alaska-Nenana coal province. See figure 19 for location of Healy Creek coalfield. and related mires during deposition of the Suntrana Formation. These streams evolved into high-sinuosity (meandering) streams and accompanying mires during deposition of the Lignite Creek Formation. Raised mires were associated with these streams, forming on abandoned deposits of alluvial belts and flood basins. These mires were common during the deposition of the Suntrana Formation, and topogenous or low-lying mires, where thin peats accumulated, were common during the deposition of the Lignite Creek Formation. Another damming of the downstream extent of these streams by uplift of the Alaskan Range created a lake that was infilled by alluvial-fan delta sediments of the Grubstake Formation. Continued uplift and lowering of base level resulted in northward-flowing alluvial fans to be shed from the Alaskan Range, forming the Nenana Gravel.

\section{Healy Creek Formation}

The Healy Creek Formation is the oldest rock unit in the Usibelli Group (fig. 20). The formation, as much as $445 \mathrm{ft}$ $(136 \mathrm{~m})$ thick, consists of interbedded sandstones, conglomerates, siltstones, and mudstones, including carbonaceous shale and coal beds. Sandstone is the most common rock type and coal is the least common. It unconformably overlies the pelitic and quartzose schist sequence (Csejety and others, 1992) with erosional relief of as much as a few hundred feet.

In most of the synclinal coalfields, the Healy Creek Formation is early to middle Miocene (Wolfe and Tanai, 1980; Wahrhaftig, 1987); but in the Rex Creek coalfield, where the formation was formerly thought to be as old as late Oligocene (Wolfe and Tanai, 1980), it is now regarded to be as old as late Eocene (Wolfe and Tanai, 1987).

The Healy Creek Formation consists mainly of finingupward sequences of conglomerates, sandstones, and silty sandstones (fig. 24). The conglomerates are composed of sedimentary, igneous, and low- to medium-grade metamorphic rock types (Stevens, 1971). The sandstones are mainly quartz-feldspathic-rich rocks. The lower $130 \mathrm{ft}(40 \mathrm{~m})$ consists mainly of amalgamated, basally scoured, lenticular pebblecobble conglomerates and sandstones (Stanley and others, 1992). The lowermost conglomerate beds rest with sharp, erosional contact on the pelitic and quartzose schist sequence. Conglomerates are normally graded, clast supported, and crudely imbricated (fig. 25). Sandstones exhibit abundant tabular and trough crossbeds in sets generally less than $2.3 \mathrm{ft}$ $(70 \mathrm{~cm})$ in height. Ripple and small-scale cross laminations are common. Also present are scour surfaces at the bases of the conglomerates and sandstones with as much as $10 \mathrm{ft}(3 \mathrm{~m})$ of erosional relief.

Interbedded sandstones, siltstones, mudstones, coals, and carbonaceous shales (fig. 26) overlie the conglomeratic and sandy interval of the Healy Creek Formation. The sandstones exhibit erosional basal surfaces, fine upward, and are crossbedded (mainly trough and planar crossbeds). Rooted siltstones and mudstones overlie the sandstones and are interbedded with coal and carbonaceous shales. Coal beds have combined thickness of as much as 49-61 ft (15-20 m), and individual beds persist laterally for more than $0.6 \mathrm{mi}$ (1 $\mathrm{km}$ ). They commonly pinch out, split, and (or) merge. Also, 
(A) HEALY CREEK FORMATION

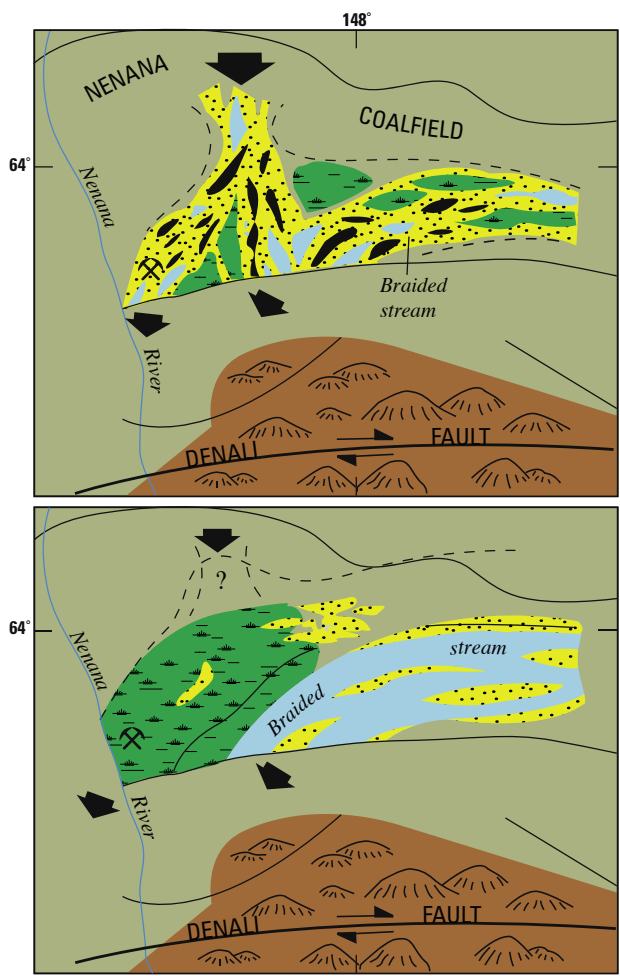

(C) SUNTRANA FORMATION
(B) SANCTUARY FORMATION
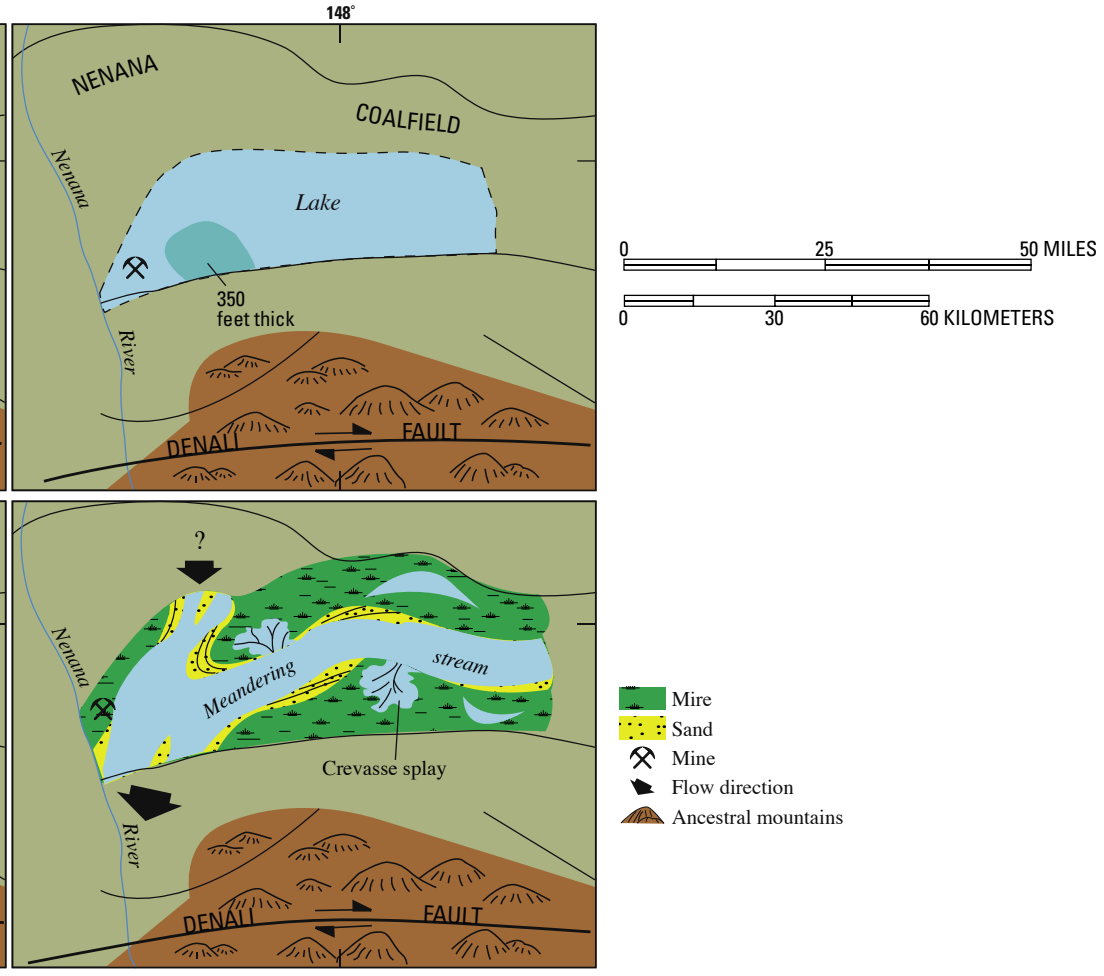

Figure 22. Paleogeographic maps showing depositional environments of: (A) Healy Creek Formation, (B) Sanctuary Formation, (C) Suntrana Formation, and (D) Lignite Creek Formation. Adopted from Flores and Stanley (1995).

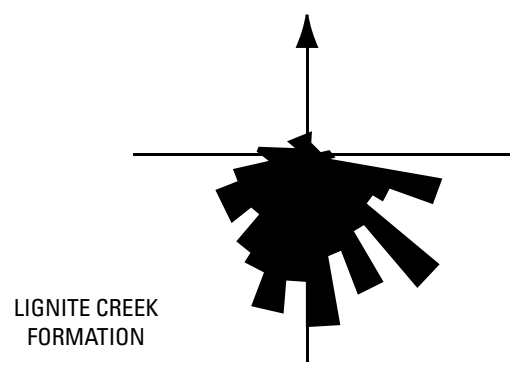

TROUGH LIMBS $\mathrm{N}=177$

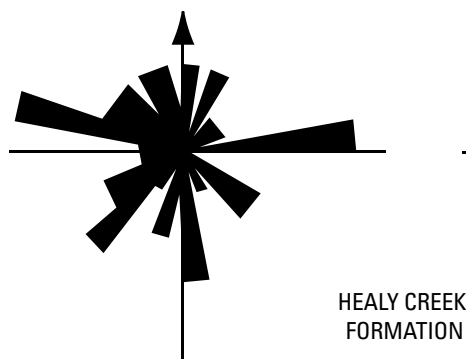

TROUGH LIMBS $\mathrm{N}=49$

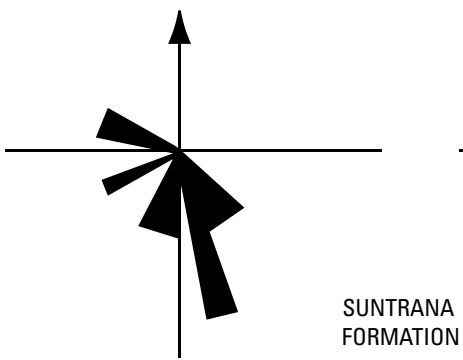

CLAST IMBRICATION $\mathrm{N}=11$

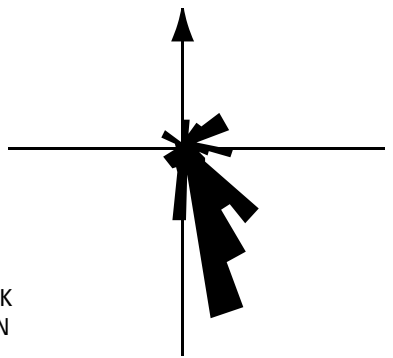

CLAST IMBRICATION $\mathrm{N}=38$

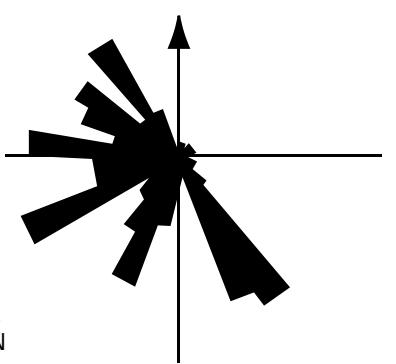

TROUGH LIMBS $\mathrm{N}=115$

PALEOCURRENTS

AT

SUNTRANA

Figure 23. Crossbed-orientation measurements in fluvial-channel sandstones in the Healy Creek, Suntrana, and Lignite Creek Formations in Suntrana area. Modified from Flores and Stanley (1995). 


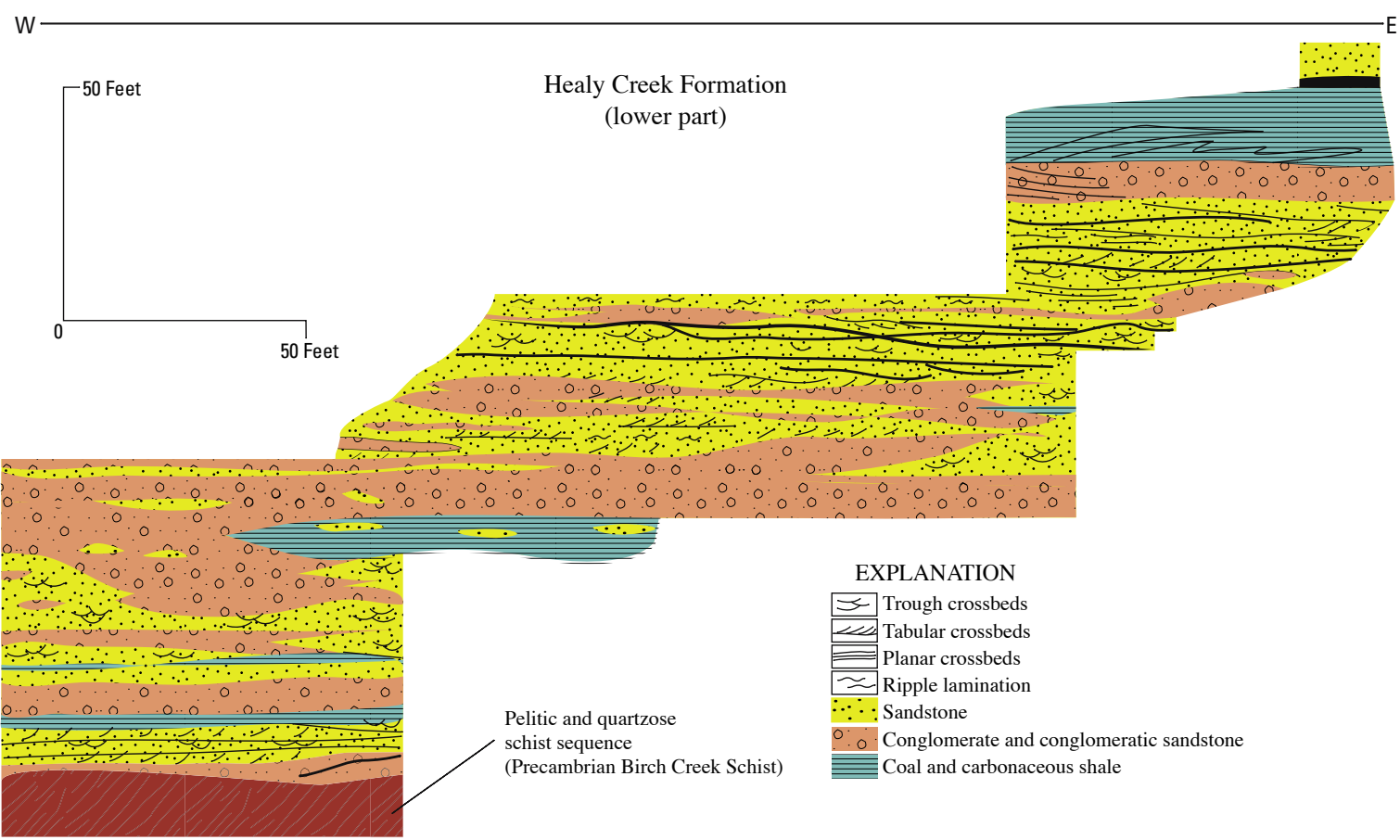

Figure 24. Stratigraphic cross section showing the basal conglomerates and sandstones in the lower part of the Healy Creek Formation east of Suntrana. Adopted from Flores and Stanley (1995). See figure 19 for location of cross section.

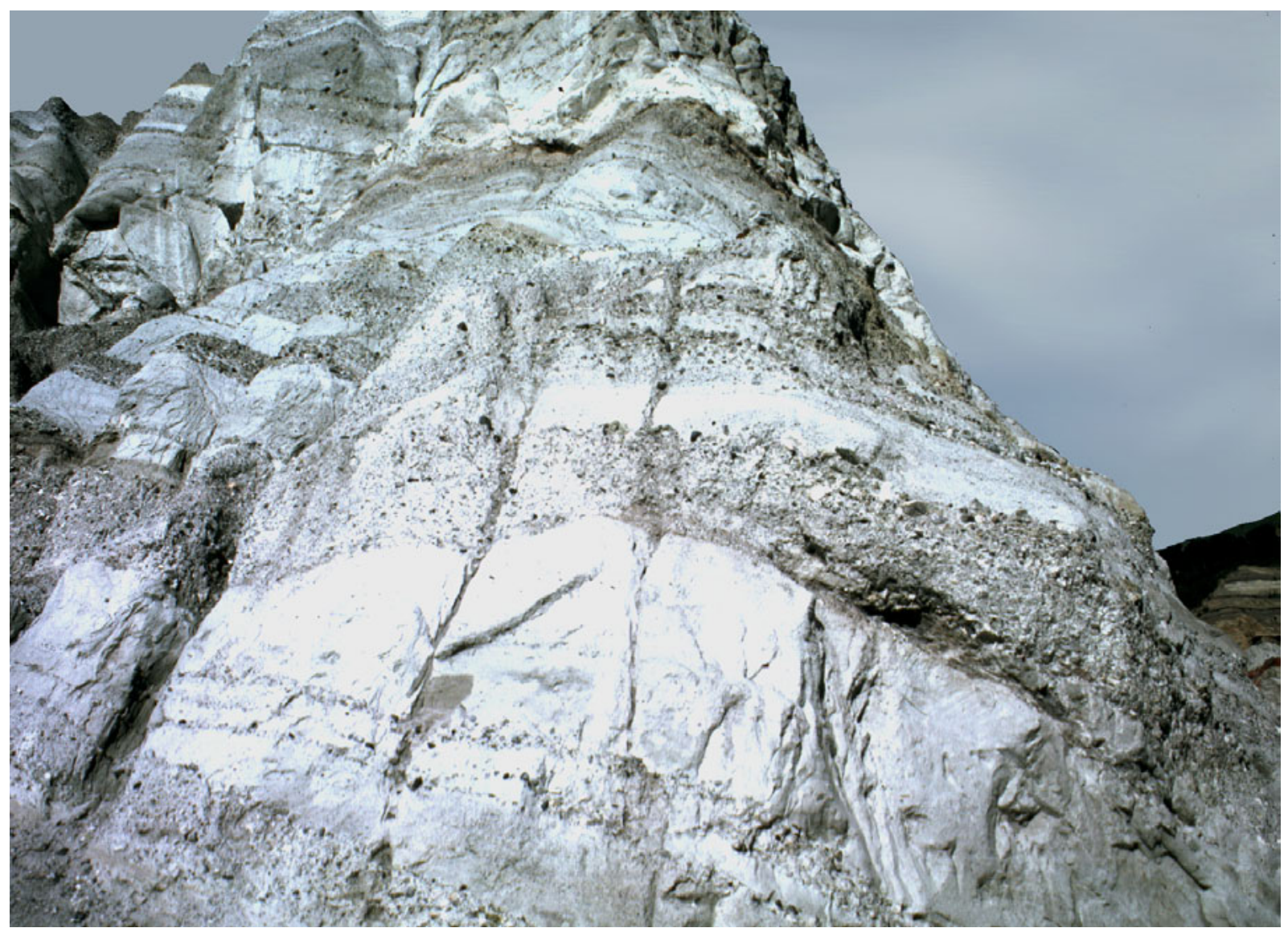

Figure 25. Photograph of conglomerates (a few inches to 5 feet thick or a few centimeters to 1.5 meters) and sandstones (6 inches to 8 feet thick or 15.2 centimeters to 2.4 meters) deposited by braided streams in the lower part of the Healy Creek Formation in east of Suntrana. 


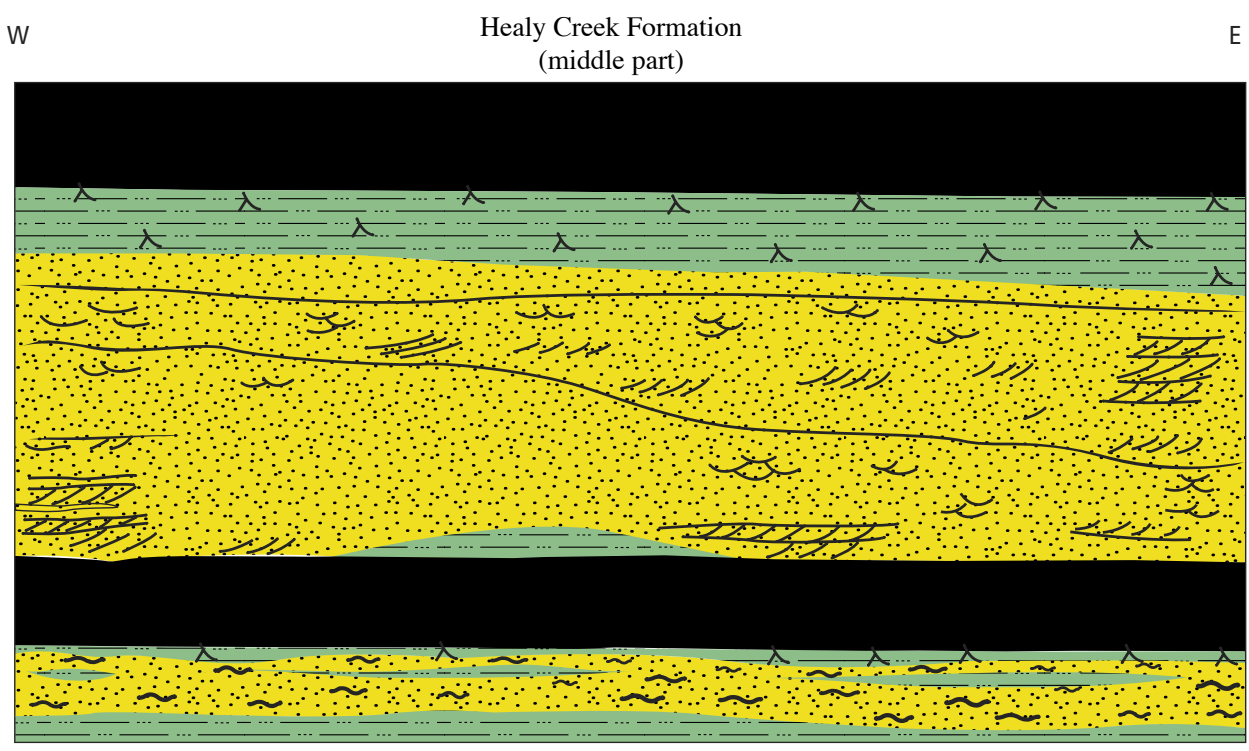

Figure 26. Stratigraphic cross section showing the middle, coalbearing part of the Healy Creek Formation east of Suntrana. See figure 19 for location of cross section. Adopted from Flores and Stanley (1995).
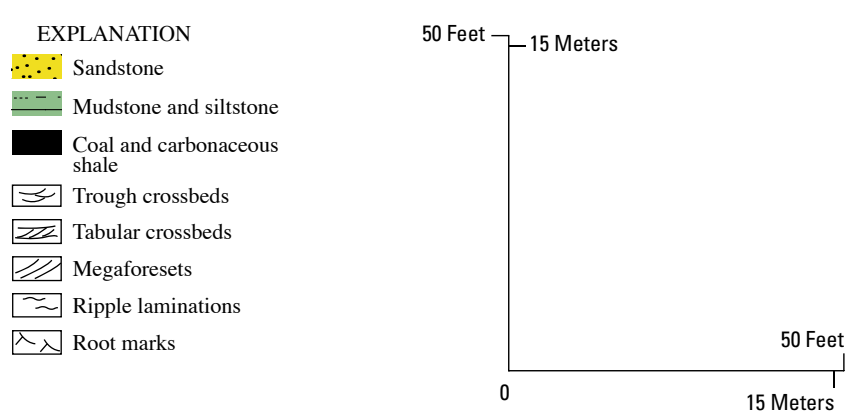

Figure 27. Stratigraphic cross section of the uppermost part of the Healy Creek Formation showing the fluvial-channel sandstones and F coal bed, and overlying Sanctuary Formation east of Suntrana. See figure 19 for location of cross section. Adopted from Flores and Stanley (1995).

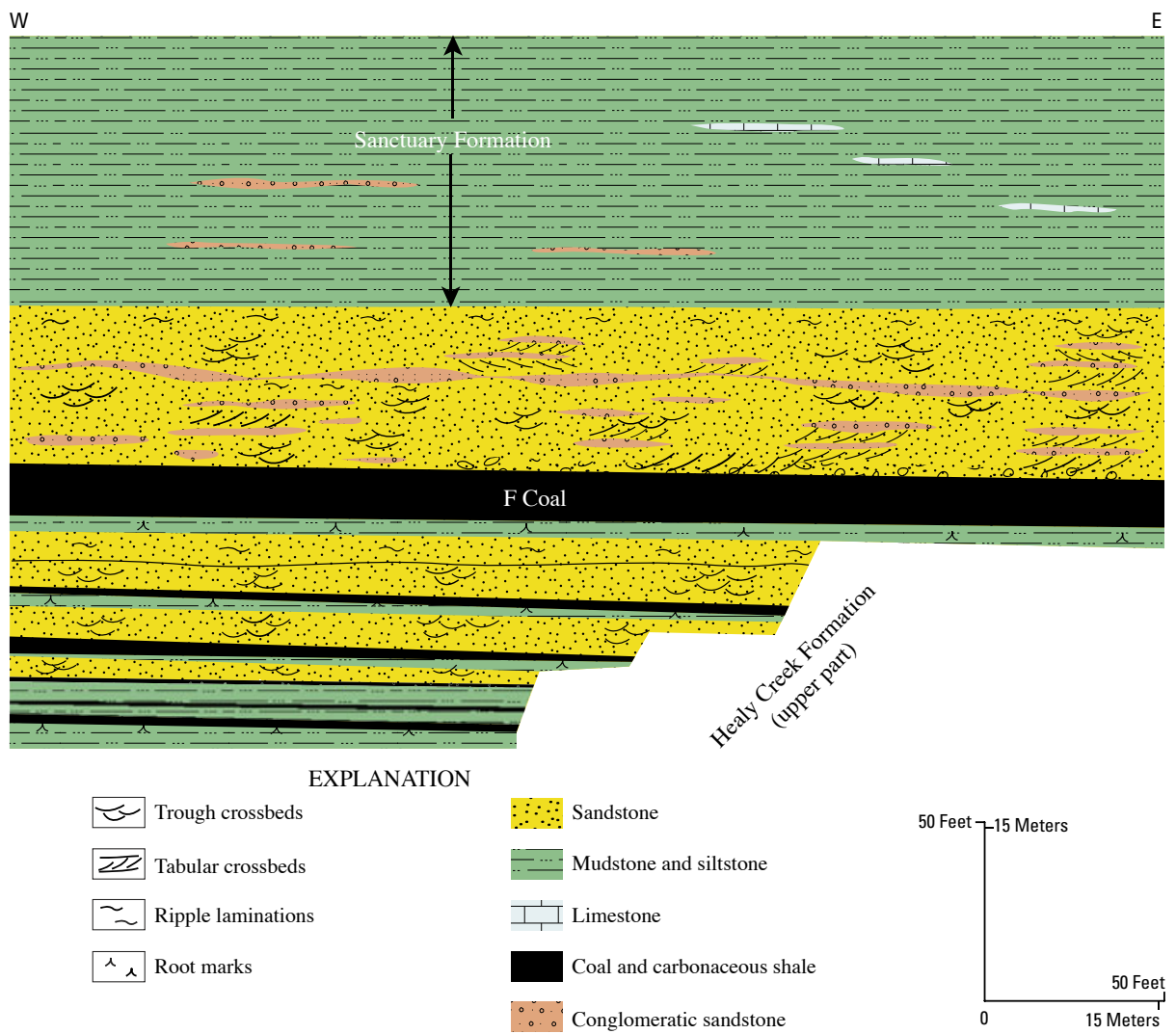


they interfinger with carbonaceous shales, mudstones, and siltstones. The highest coal bed of the Healy Creek Formation, the F coal bed (figs. 27 and 28), which immediately underlies the Sanctuary Formation, is the only coal bed of sufficiently continuous lateral extent to be analyzed for reserve estimates (Wahrhaftig and others, 1994).

The Healy Creek Formation was interpreted to originate as braided to high-sinuosity stream deposits (Buffler and Tripplehorn, 1976; Selleck and Panuska, 1983; Stanley and others, 1992). The streams may have formed on a wet alluvial fan or on a proximal braid plain where the cobbles, pebbles, and sands were likely deposited by migrating longitudinal gravel bars and sandy transverse bars. The interbedded sandstones, siltstones, and mudstones probably were deposited in low-sinuosity fluvial channels and flood plains. Coal beds and carbonaceous shales may have accumulated in raised mires or abandoned mires built atop abandoned fluvial channels and flood-plain deposits.

\section{Sanctuary Formation}

The Sanctuary Formation is composed mainly of $130 \mathrm{ft}$ $(40 \mathrm{~m})$ of gray, thinly laminated, varved mudstone and shale that weather chocolate brown (fig. 29). Mudstones commonly exhibit nondescript vertical animal burrows. The formation also contains minor sandstone, siltstone, and limestone. Sandstones are rippled and crossbedded and occur as a coarseningupward sequence with the underlying siltstones. Limestones are found as gray, micritic, lenticular beds. This formation conformably overlies the Healy Creek Formation and was assigned by Wolfe and Tanai (1980) to the middle Miocene.

The Sanctuary Formation is interpreted to have accumulated in a large, shallow lake. The lake may have originated as a series of flood-plain lakes, which coalesced due to rise of base level either by damming of the streams and (or) by tectonic uplift along the path of the streams downstream. Coarsening upward sandstones and siltstones probably represent lacustrine deltas shed either from the nearby fluvial channels or from fan deltas.

\section{Suntrana Formation}

The Suntrana Formation unconformably overlies the Sanctuary Formation and is as thick as $1,310 \mathrm{ft}(400 \mathrm{~m})$ (see fig. 21). The formation, as a whole, thickens gradually southeastward and pinches out in the northwestern part of the coal province. It consists of interbedded sandstones, siltstones, mudstones, carbonaceous shales, and coal. Sandstones are abundant, erosional based, fining upward, mainly trough and planar crossbedded with crossbeds $3.2-6.5 \mathrm{ft}(1-2 \mathrm{~m})$ in height, and pebbly at the base (figs. 30 and 31 ). They grade either into rooted siltstone, mudstones and silty sandstones or are locally unconformably overlain by these deposits (fig. 32). Coal beds are interbedded with carbonaceous shales and have a combined thickness ranging from 1.6 to $65 \mathrm{ft}(0.5$ to $20 \mathrm{~m})$.
Most of the coal beds can be traced laterally over distances of as much as $15 \mathrm{mi}(25 \mathrm{~km})$ (Wahrhaftig, 1973). Two of the thicker beds (Nos. 3 and 4) are currently mined in the Usibelli coal mine at Poker Flats (figs. 33 and 34). Thickness of the No. 6 coal bed, the highest coal bed, is shown in figure 35 . The Suntrana Formation was assigned by Wolfe and Tanai (1980) to middle Miocene.

The fining-upward, erosional-based sandstones of the Suntrana Formation probably were deposited in braided streams by migrating longitudinal bars and transverse side channel bars (Stanley and others, 1992; Flores and Stanley, 1995). An upward decrease in grain size reflects decreasing flow resulting from switching and lateral migration of the stream channels. The erosional-based siltstones, mudstones,

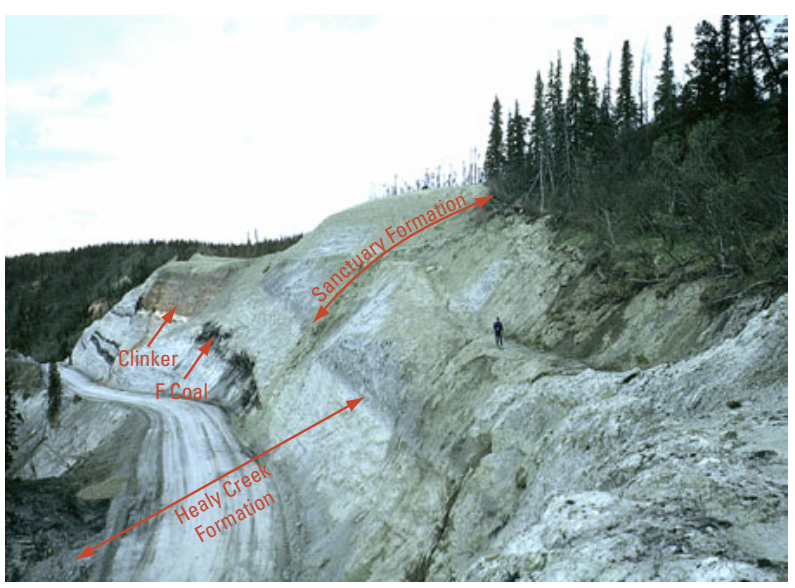

Figure 28. Photograph of the uppermost part of the Healy Creek Formation, $\mathrm{F}$ coal bed, and overlying mudstones of the Sanctuary Formation in the Lignite Creek coalfield. Man for scale is 6 feet (1.8 meters) tall.

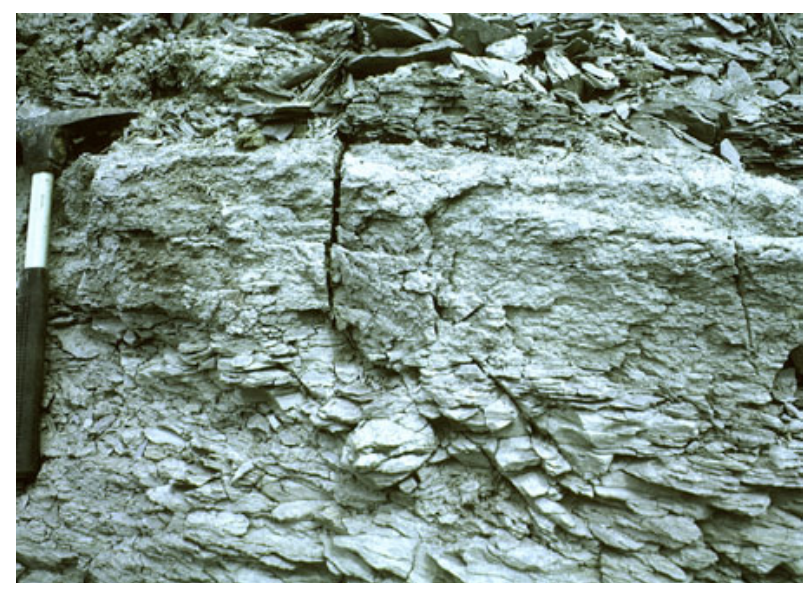

Figure 29. Photograph of the lacustrine mudstone and lenticular limestone units in the Sanctuary Formation in the Lignite Creek coalfield. Hammer on left for scale is 1 foot (0.3 meter) long. 
and silty sandstones that scoured into the fining-upward sandstones represent deposits in abandoned fluvial channels. A thick coal bed commonly overlies the fining-upward sandstones, which reflect accumulation of peat on raised mires. Abandoned fluvial channel deposits served as platforms on which raised mires could be sustained for a long period of time without drowning by detritus during floods from streams. However, when the mires were formed in low topography, detrital sediments flooded the mires and flood plains by crevasse splays and overbank splays, as indicated by interbedded mudstones, siltstones and silty sandstones. The thick crevasseoverbank sequence and associated thin coal beds indicate rapid sedimentation and local subsidence.

\section{Lignite Creek Formation}

The Lignite Creek Formation, which is from 490 to $790 \mathrm{ft}$ (150 to $240 \mathrm{~m}$ ) thick, overlies and is conformably gradational with the Suntrana Formation (see fig. 20). The Lignite Creek consists of interbedded sandstones, siltstones, mudstones, carbonaceous shales, and coals; sandstones and mudstones are the most dominant. The sandstones are fining-upward pebble to coarse grained in the lower part and fine grained in the upper part. They have an erosional, pebbly base and are trough and planar crossbedded. The fining-upward sandstone is commonly overlain by, and gradational to, interbedded siltstone, mudstone, and coal at the top (figs. 36 and 37). The coal beds are thin, generally less than $3 \mathrm{ft}(1 \mathrm{~m})$ thick, woody, and relatively lenticular and interbedded with coarseningupward mudstones, siltstones, and silty sandstones (fig. 38); they pinch out northward. A noncoal-bearing conglomeratic deposit, as much as $37 \mathrm{ft}(11 \mathrm{~m})$ thick, occurs along the north and west margins of the Nenana coal field. Wolfe and Tanai (1980) have assigned the Lignite Creek Formation to the late middle to early late Miocene age.

The dominant mudstones and sandstones in the Lignite Creek Formation reflect its deposition in a high-sinuosity or meandering stream setting. Mudstones represent suspended load from these meandering streams, which overtopped the banks of the streams during floods. Continuous overtopping of the streambanks of muds resulted in accumulation of thin coals, mainly $<3.2 \mathrm{ft}(1 \mathrm{~m})$ thick, in generally low-lying mires. Coal beds are platy and appear to contain mats of branches and twigs unlike the blocky appearance of the coal beds in the Healy Creek and Suntrana Formations. The difference in appearance is probably due to lower apparent rank of the Lignite Creek coal.

\section{Grubstake Formation}

The stratigraphically highest formation assigned to the Usibelli Group is the Grubstake Formation (see fig. 20; Wah-
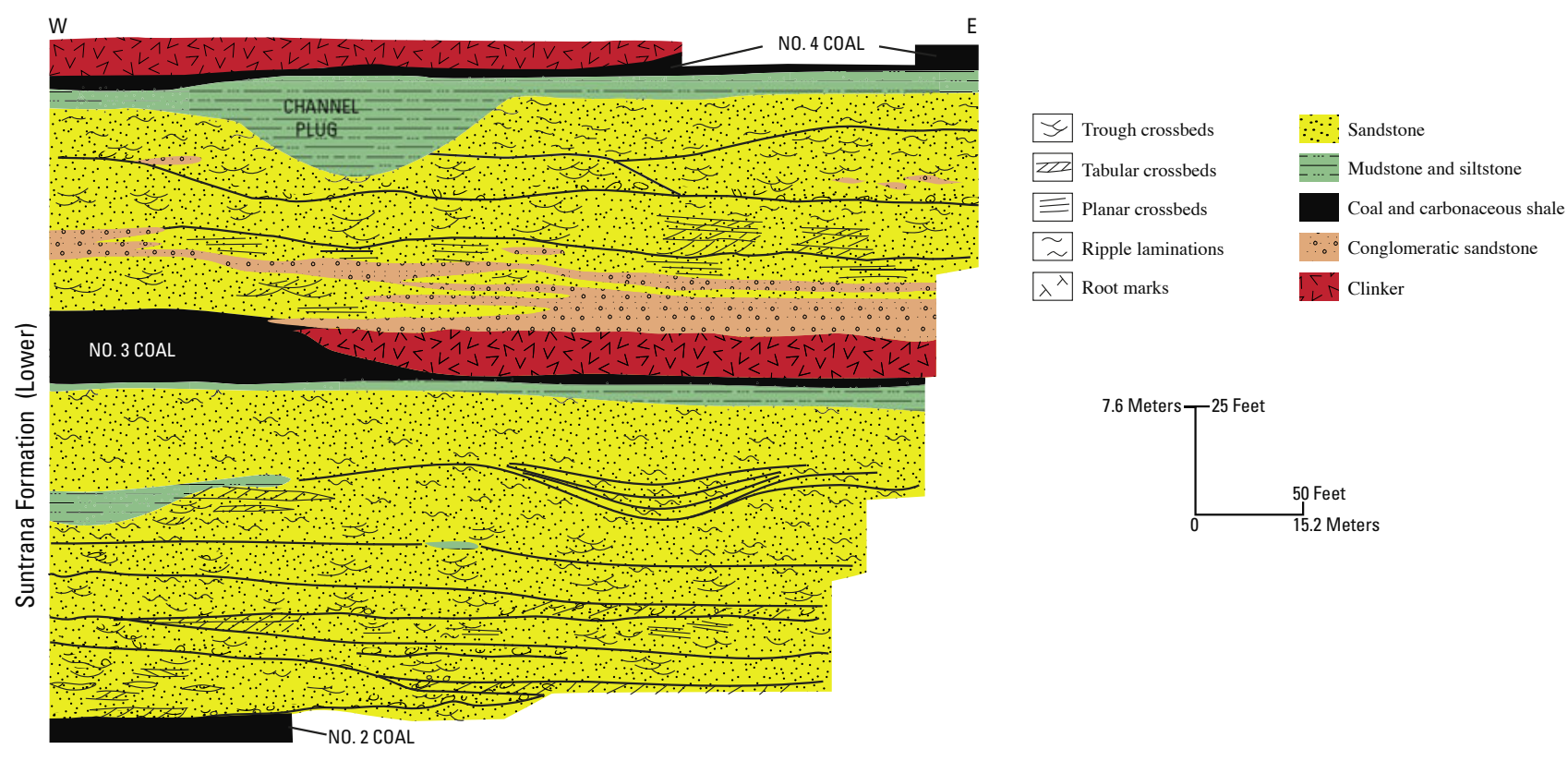

Figure 30. Stratigraphic cross section of the Suntrana Formation showing the Nos. 2, 3, and 4 coal beds and interbedded fluvialchannel sandstones west of Suntrana. See figure 19 for location of cross section. Adopted from Flores and Stanley (1995). 


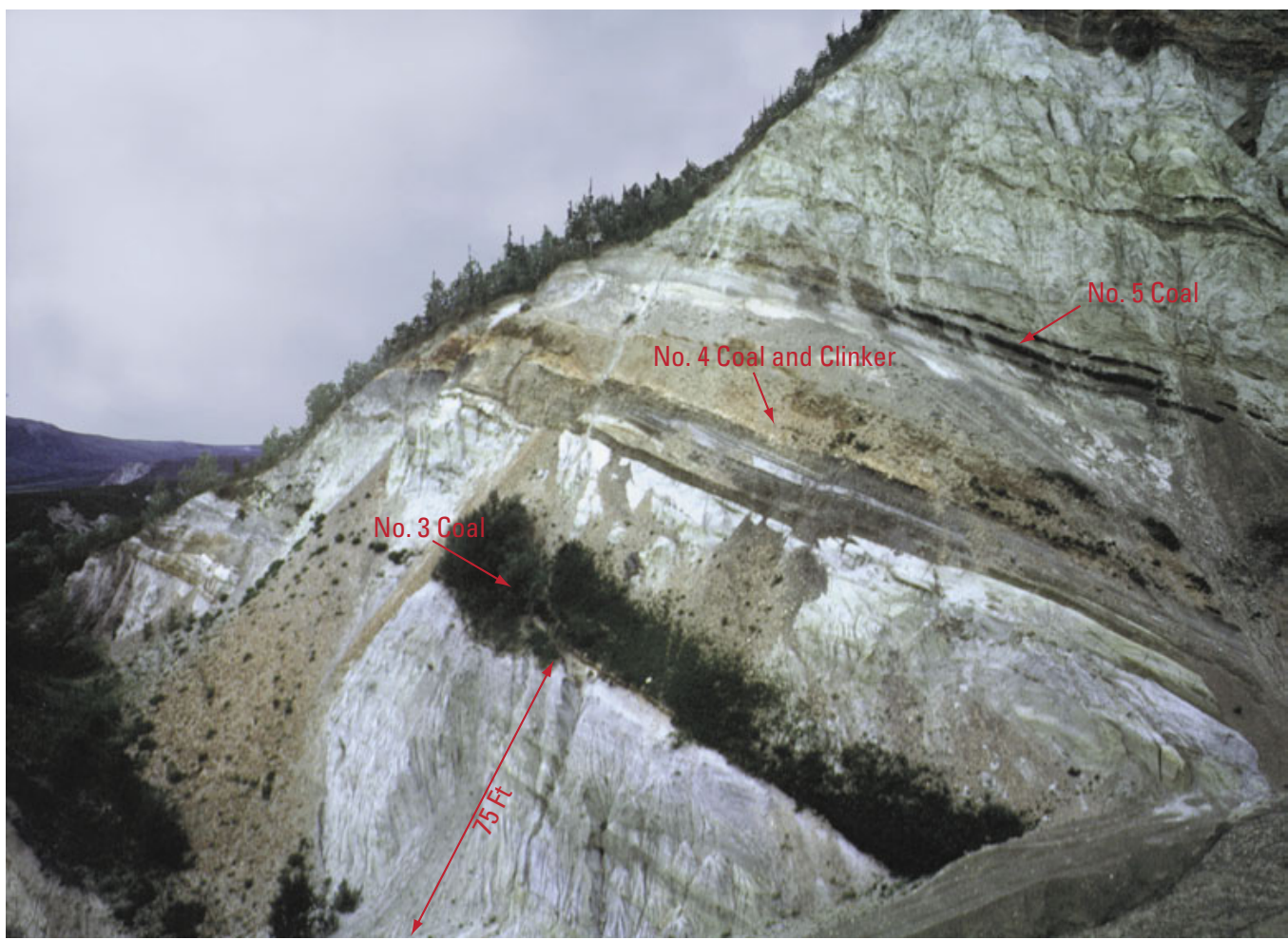

Figure 31. Photograph of the Suntrana showing the thick No. 3 coal bed, clinker bed of No. 4 coal bed, thin No. 5 coal bed, and interbedded fluvial-channel sandstones and clay plug-overbank deposits west of Suntrana. For scale, the sandstone below No. 3 coal bed is 75 feet (22.8 meters) thick.

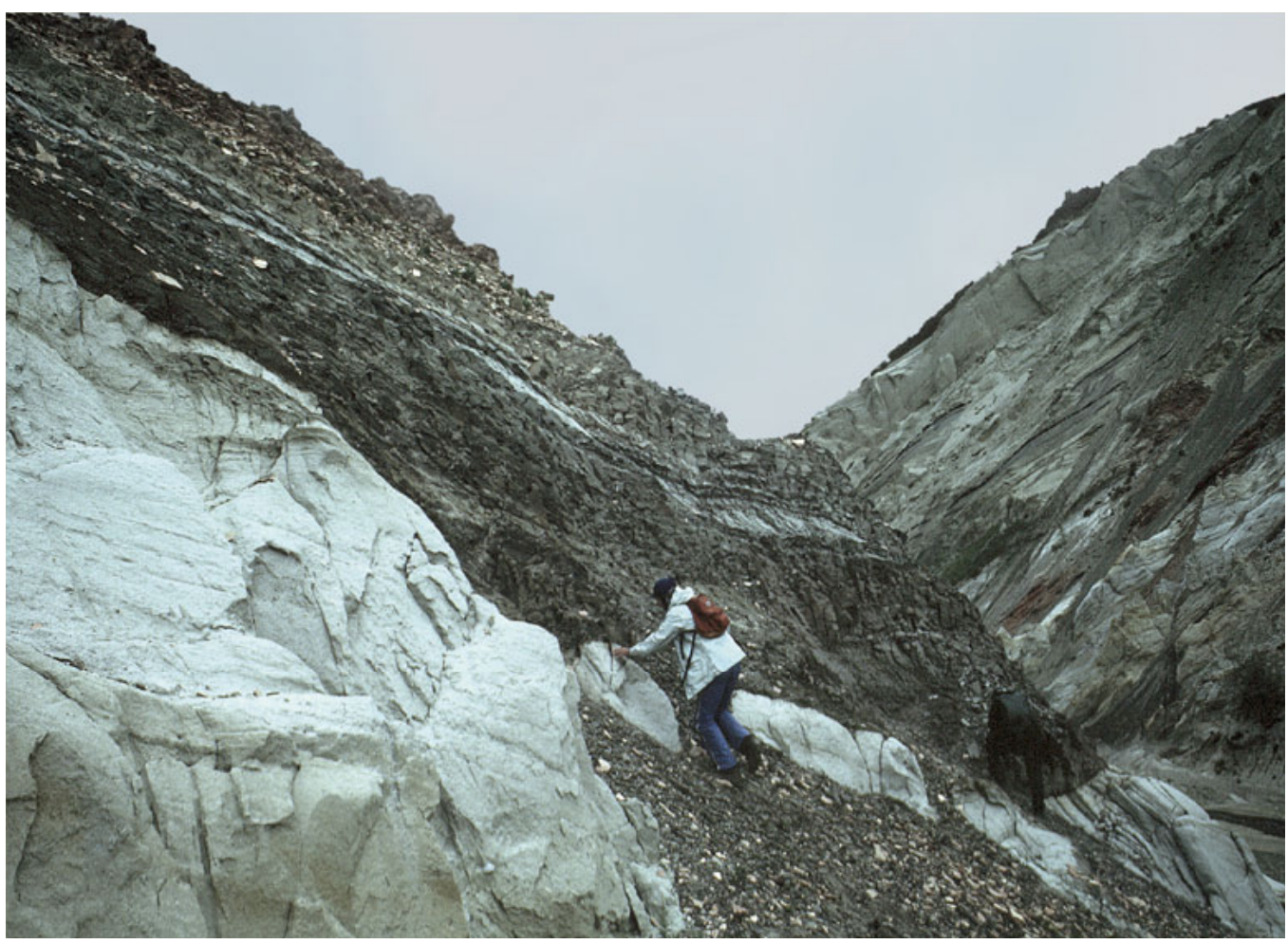

Figure 32. Photograph of the abandoned fluvial-channel mudstone or clay plug deposit. Note erosional basal contact of the clay plug deposits west of Suntrana. Man is 6 feet (1.8 meter) tall for scale. 
$S$

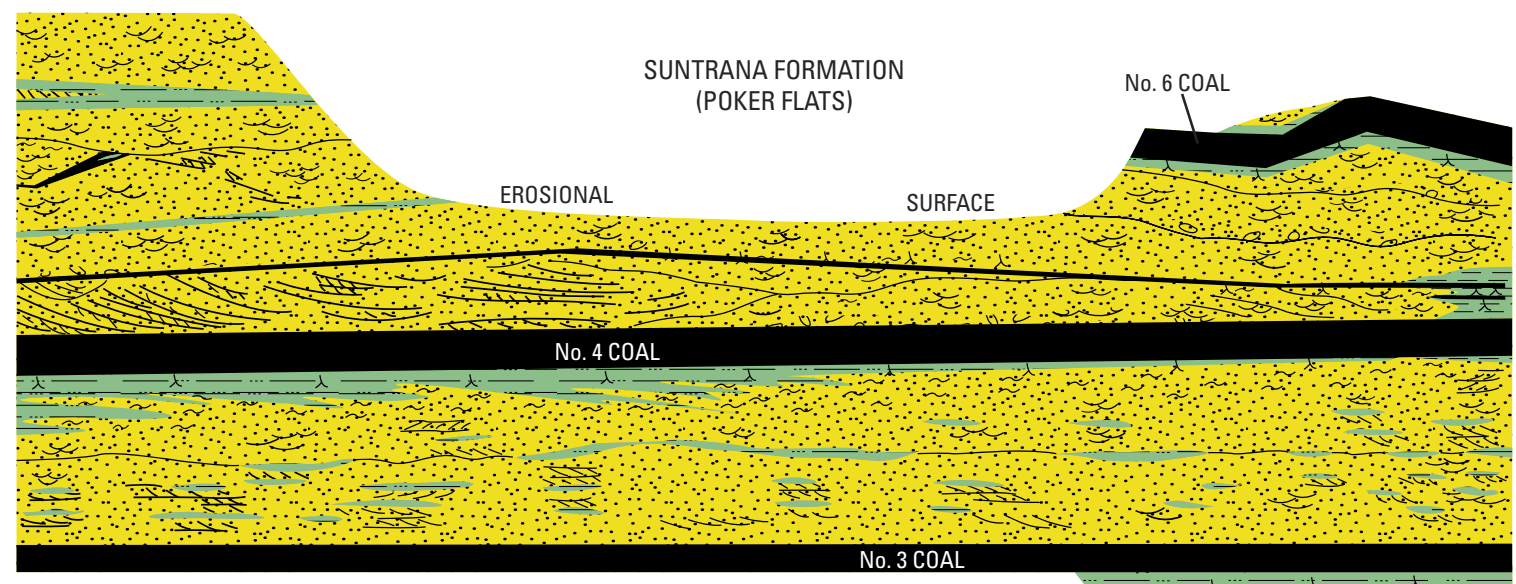

EXPLANATION

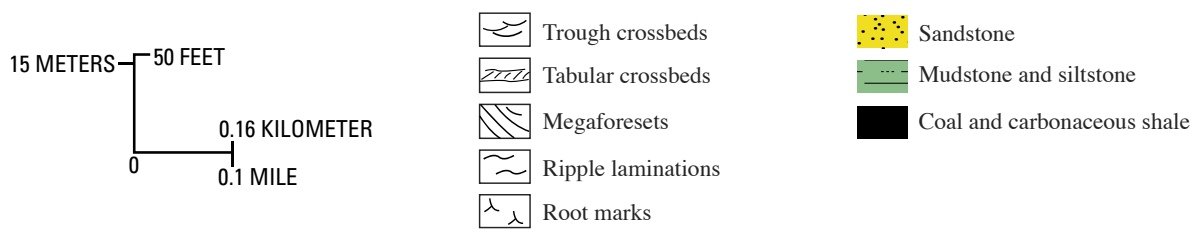

Figure 33. Stratigraphic cross section of the Nos. 3, 4, and 6 coal beds of the Suntrana Formation in the Poker Flats strip mine of Usibelli Coal Mine. Here the Nos. 3 and 4 coal beds are mined. See figure 19 for location of cross section. Adopted from Flores and Stanley (1995).

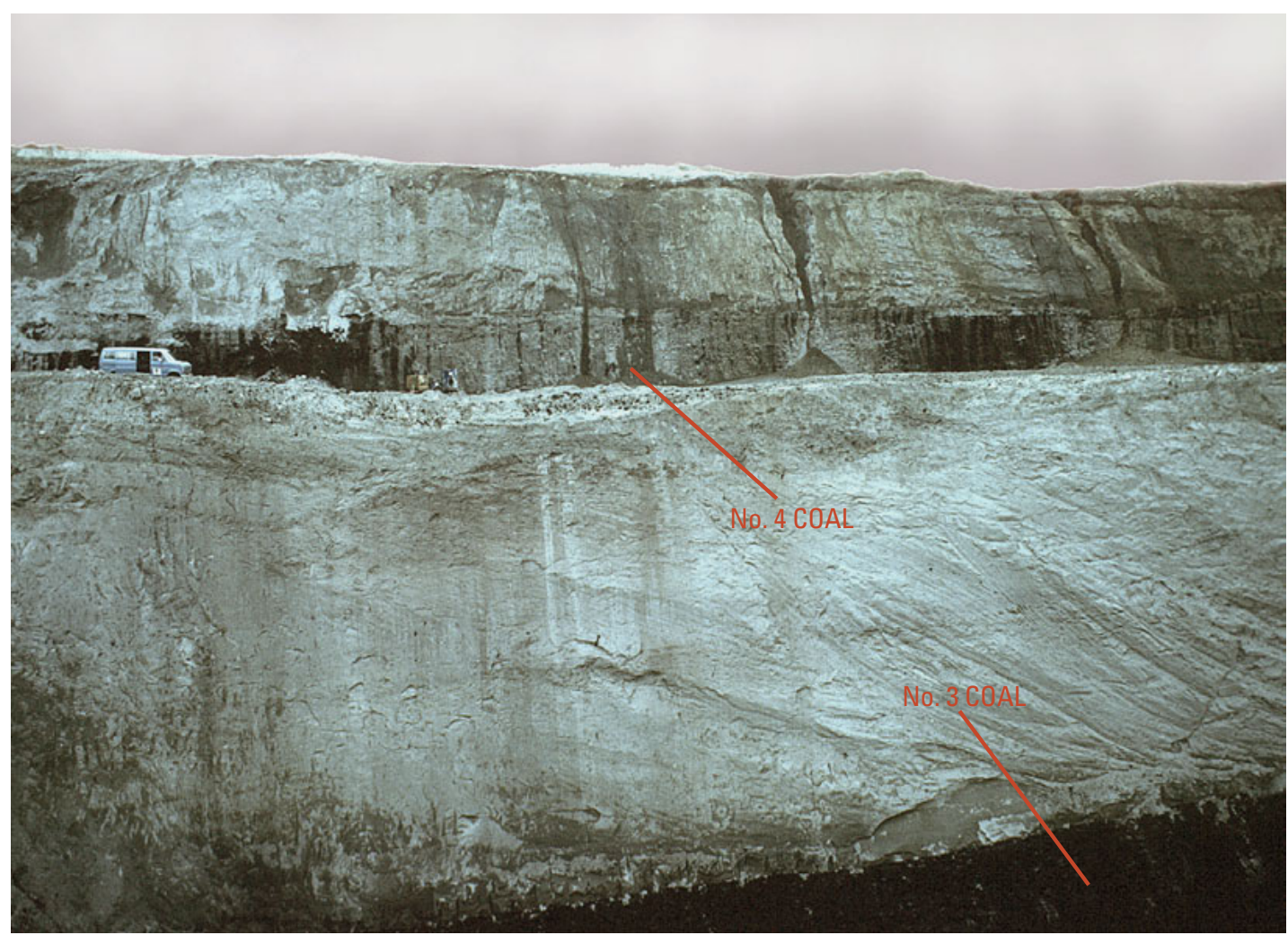

Figure 34. Photograph of the Poker Flats strip mine showing the highwall exposing fluvial-channel sandstones and No. 3 coal bed (lower bench) and No. 4 coal bed (upper bench). For scale, the sandstone between the Nos. 3 and 4 coal beds is 100 feet ( 30 meters) thick. White dashed line is the contact between the coal and fluvial-channel sandstone. 


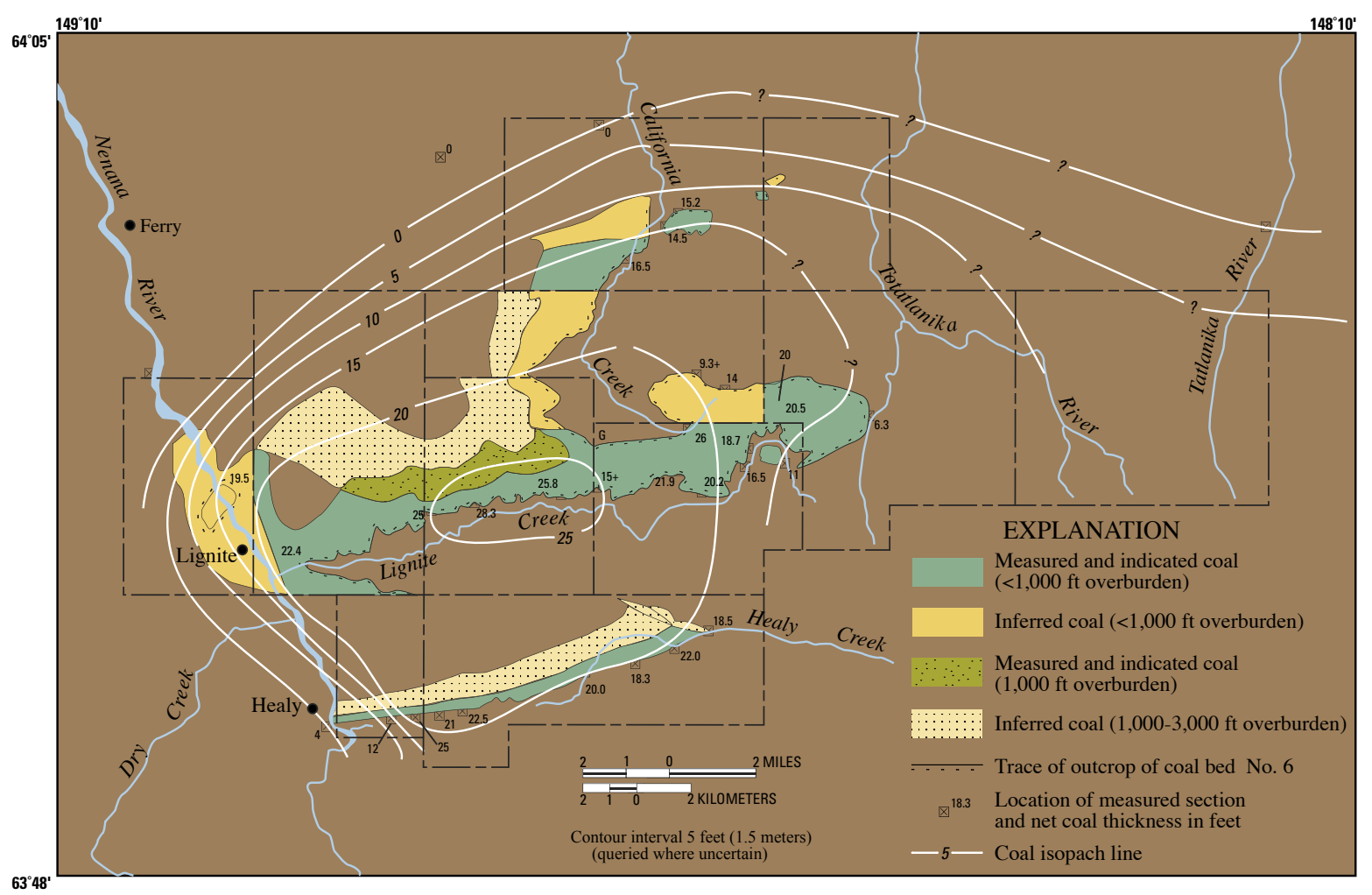

Figure 35. Thickness map of the No. 6 coal bed of the Suntrana Formation. Modified from Wahrhaftig and others (1994).

rhaftig and others, 1994). This formation consists of dark gray laminated shale and mudstone that is $590-980 \mathrm{ft}(180-300$ $\mathrm{m})$ thick in the northeastern part of the Nenana coal province but only 2-6 ft (0.6-1.9 m) thick in the southwestern part. In the eastern part of the coal province, the Grubstake Formation interfingers southward with coarse-grained, dark, unconsolidated sandstones similar to those in the overlying Nenana Gravel. A K-Ar age on rhyolitic glass from an ash layer in the lower part of the Grubstake Formation is $8.3 \pm 0.4 \mathrm{Ma}$, which coincides with a late Miocene age based on plant megafossils (Wahrhaftig and others, 1969; Wolfe and Tanai, 1980; Wahrhaftig, 1987).

The Grubstake Formation probably accumulated in a lake closely similar to that of the Sanctuary lake. The lake was formed by the damming of southward-flowing Lignite Creek paleostreams by the rising Alaska Range and may be the result of coalesced flood-plain lakes and fluvial channels due to the rise of base level caused by tectonic damming.

\section{Nenana Gravel}

The Nenana Gravel consists of poorly consolidated, buff to red, pebble- to boulder-size conglomerates overlying the Usibelli Group. It ranges in thickness from 3,940 ft $(1,200 \mathrm{~m})$ at the south edge of the Nenana coal province to 980-1,310 $\mathrm{ft}(300-400 \mathrm{~m}$ ) along the north edge of the Alaska Range foothills. Gravel detritus was shed northward from the rising
Alaska Range that blocked the southward-flowing tributary to the Cook Inlet-Susitna Lowland (Wahrhaftig, 1970). Its age is bracketed between 8.3 and $2.75 \mathrm{Ma}$, so is contemporaneous with the Sterling Formation in the Cook Inlet area. The Nenana Gravel is much more widely distributed than the Usibelli Group, which is primarily confined to synclinal basins deformed early in the orogeny that later deposited the Nenana Gravel. Along much of its outcrop length, the formation rests on rocks older than the Usibelli Group, and detritus from the Usibelli Group can be recognized in the Nenana Gravel.

\section{Coal Resource Assessment of the Central Alaska-Nenana Coal Province}

The coal resource assessments of different workers in the Central Alaska-Nenana coal province differ in magnitude and coal resource categories, which result in varying estimates. We reconstructed these different coal resource estimates following guidelines of the coal-resource classification system of Wood and others (1983). This new reporting system of the coal resources of the Central Alaska-Nenana coal province, modified from previous estimates is summarized in table 1 . Following is a historical account of the diverse coal resource assessments in the coal province. 
W
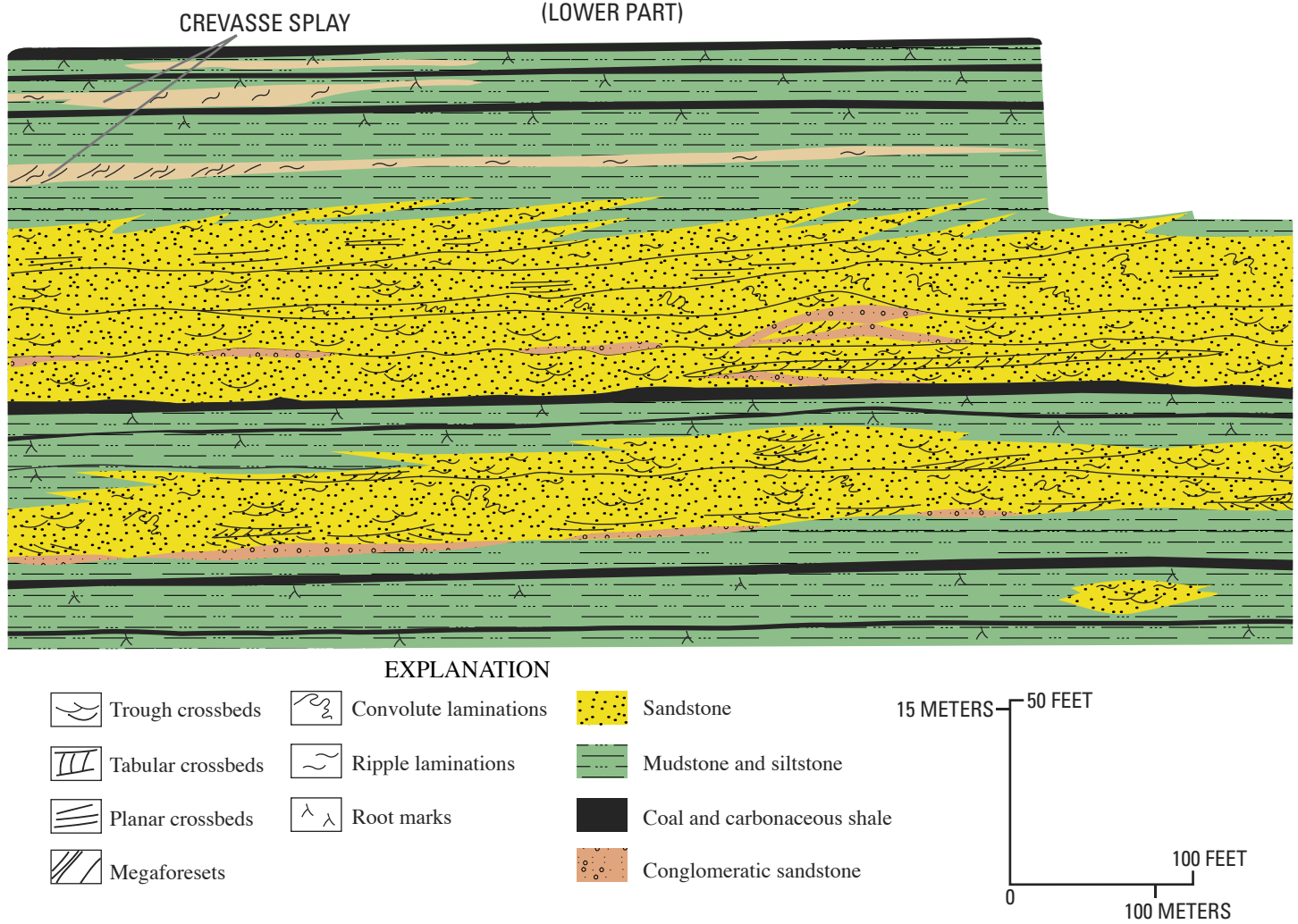

Figure 36. Stratigraphic cross section of the lower part of the Lignite Creek Formation showing interbedded fluvial-channel sandstones, crevasse splay flood-plain deposits, and thin coal beds west of Suntrana. See figure 19 for location of cross section. Adopted from Flores and Stanley (1995).

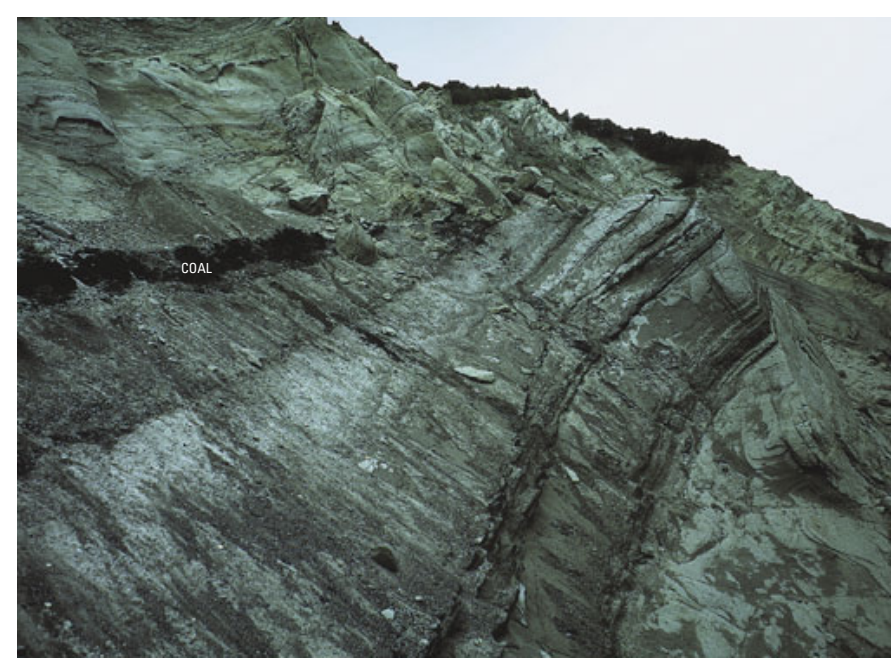

Figure 37. Photograph of the interbedded fluvial-channel sandstones, flood-plain deposits, and an interbedded thin coal bed of the Lignite Creek Formation west of Suntrana. For scale, the upper coal bed is 3 feet ( 0.9 meter) thick.

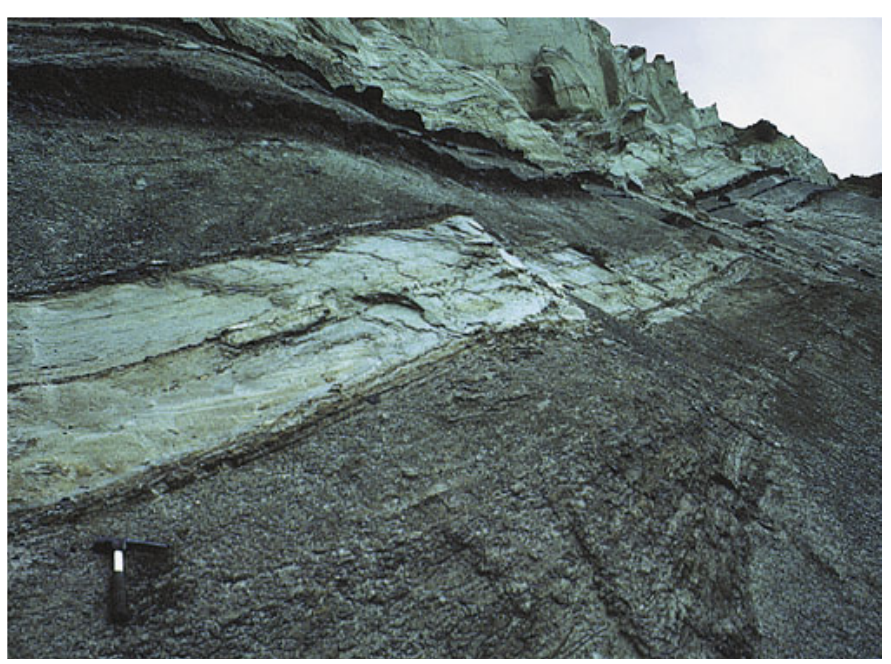

Figure 38. Photograph of the coarsening-upward mudstone, siltstone, and sandstone (tabular shape) sequence overlain by thin coal beds of the Lignite Creek Formation west of Suntrana. Hammer on lower left for scale is 1 foot ( 0.3 meter) long. 
Coal was first mined in the Nenana coal province in 1918 when the Alaska Railroad reached the town of Lignite near Lignite Creek. The Suntrana Mine was an underground operation in the Healy Creek coalfield from 1922 to the mid-1950's. Strip mining by Usibelli Coal Mine (UCM) in the Healy Creek coalfield began in 1944, eventually replacing the underground mining. Several 10- to 65-ft-thick (3-20 m) coal beds within the Suntrana Formation and Healy Creek Formation are separated by $32-195 \mathrm{ft}(10-60 \mathrm{~m})$ of poorly consolidated sandstone and are overlain at the surface by sand and gravel with an overburden: coal ratio of $<5: 1$. Present technologies and economics indicate that essentially all of the strippable coal in the Healy Creek coalfield has been mined. Production from the strip and underground mines in this coalfield since January 1, 1959, was 6.6 million short tons (5.9 million metric tons) (Barnes, 1967a). Approximately 18 million short tons (16 million metric tons) of coal has been produced from the Lignite Creek coalfield by the UCM from 1977 to 1992. In 1985, 48 percent of this production was consumed in Alaska; the rest was exported to South Korea (Green and Bundtzen, 1989). Coal production has come from proven reserves in the Healy Creek and Suntrana Formations. Lignite Creek Formation contains no currently minable reserves within the mine leases.
Healy Creek and Lignite Creek coalfields contain most of the coal resources in the Central Alaska-Nenana coal province (table 4), with more than $5.9 \times 10^{9}$ short tons $\left(5.4 \times 10^{9}\right.$ metric tons) of inferred, measured, and indicated resources (Wahrhaftig, 1973). Wahrhaftig and others (1994) revised this estimate to $6.2 \times 10^{9}$ short tons $\left(5.6 \times 10^{9}\right.$ metric tons $)$. About 5.47 billion short tons ( 4.9 billion metric tons) are in beds more than $2.5 \mathrm{ft}(0.76 \mathrm{~m})$ thick (Barnes, 1967a). Coal resources are distributed as follows: 1 billion short tons (0.91 billion metric tons) identified and 2 billion short tons ( 1.8 billion metric tons) hypothetical for Healy Creek coalfield; 4.9 billion short tons ( 4.4 billion metric tons) identified and 7 billion short tons (6.4 metric tons) hypothetical for Lignite Creek coalfield (Stricker, 1991). Measured, indicated, and inferred coal resources in beds more than $2.5 \mathrm{ft}(0.76 \mathrm{~m})$ thick and from 0 to $3,000 \mathrm{ft}(915 \mathrm{~m})$ below the surface, are 4.9 billion short tons (4.4 billion metric tons) (Barnes, 1967a). About 1.36 billion short tons (1.2 billion metric tons) of total coal resources from 0 to 3,000 $\mathrm{ft}(915 \mathrm{~m})$ below the surface was estimated by Barnes (1967a) in Healy Creek coalfield and 4.1 billions short tons (3.7 billion metric tons) for Lignite Creek coalfield.

Summaries of the estimates of coal resources of other coalfields such as Jarvis Creek, Wood River, Rex Creek,

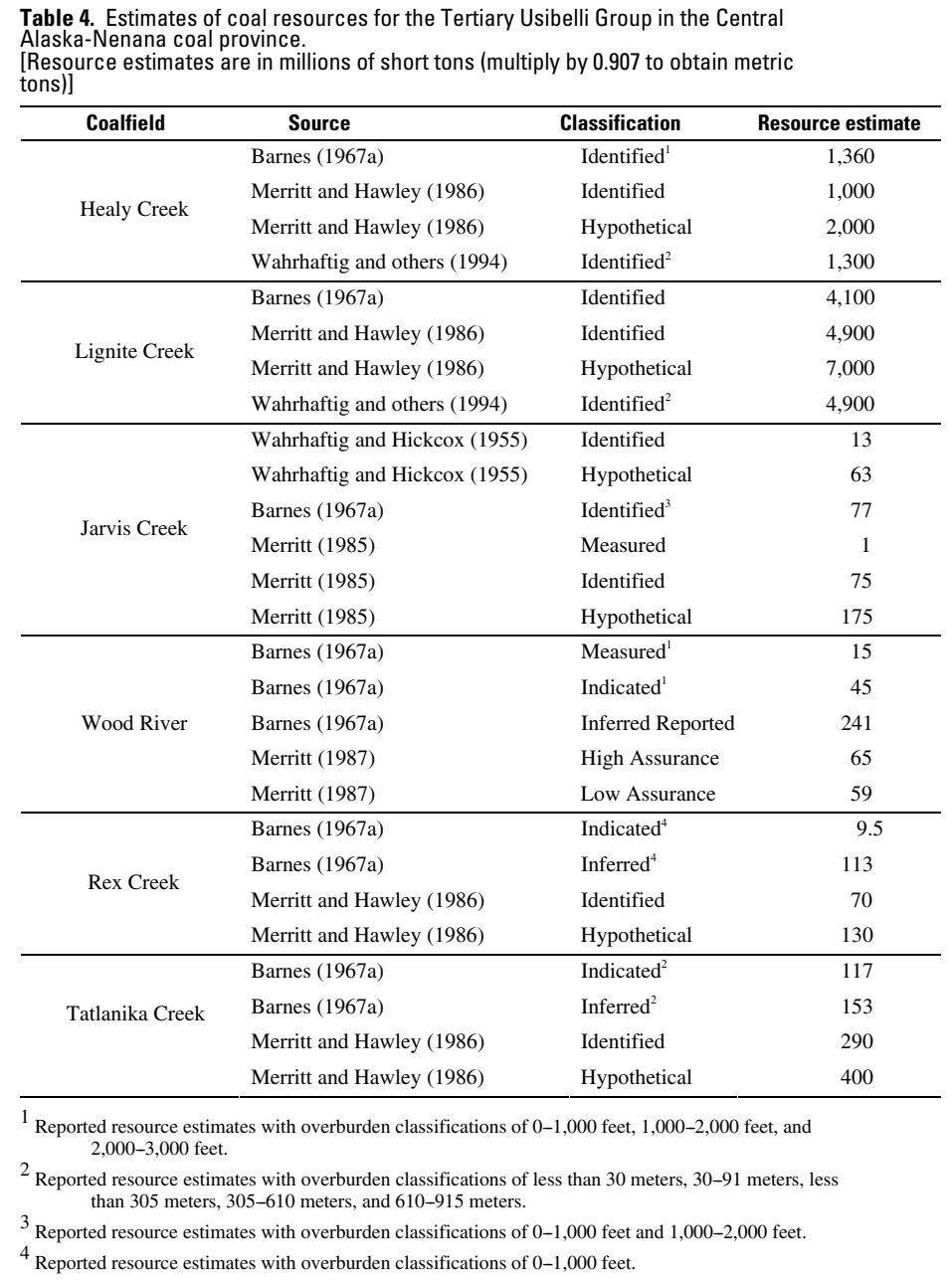




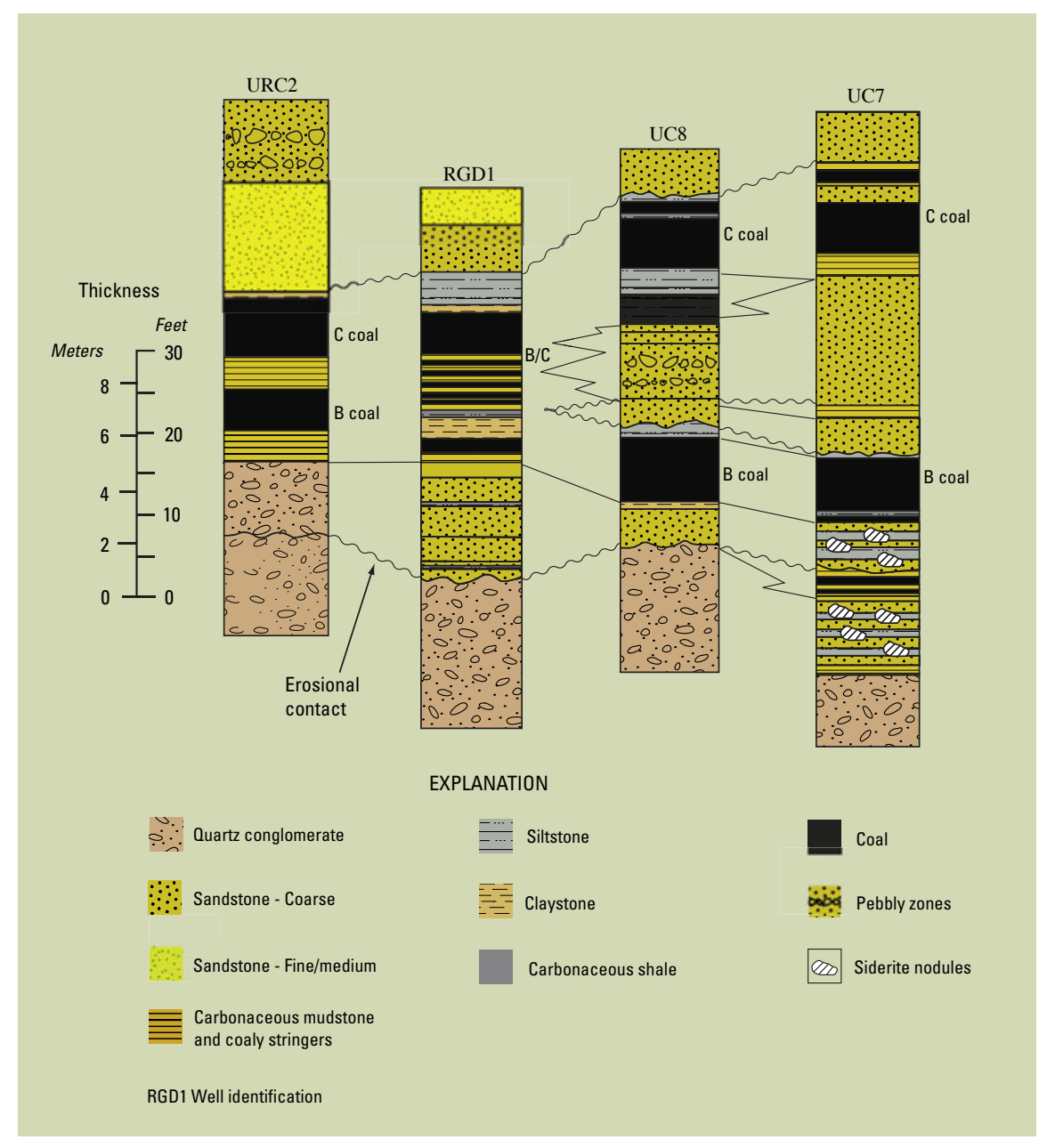

Figure 39. Stratigraphic cross section showing variation of minable Healy Creek coal beds and associated sandstones, mudstones, and siltstones in the Jarvis Creek coalfield. Modified from Belowich (1987). See figure 19 for location of cross section.

and Tatlanika Creek coalfields in the Central Alaska-Nenana coal province are in table 4. In the Jarvis Creek coalfield, the coal-bearing rocks are as much as $1,970 \mathrm{ft}(600 \mathrm{~m})$ thick and underlie an area of about $40 \mathrm{mi}^{2}\left(103 \mathrm{~km}^{2}\right)$. These coal-bearing rocks were correlated with the Healy Creek Formation of the Healy Creek coalfield by Wahrhaftig and Hickcox (1955). Thirty thin, discontinuous coal beds are present throughout the coal-bearing sequence, but most of these beds are less than $2.5 \mathrm{ft}(0.75 \mathrm{~m})$ thick. Wahrhaftig and Hickcox (1955) calculated $13 \times 10^{6}$ short tons $\left(12 \times 10^{6}\right.$ metric tons $)$ of indicated and inferred resources of coal in seven beds exposed along the south and east sides of the Jarvis Creek coalfield. These workers suggested that the coalfield might contain as much as $62 \times 10^{6}$ short tons $\left(57 \times 10^{6}\right.$ metric tons $)$ of additional coal resources for which no outcrop evidence is available. Metz (1981) reported that drilling had discovered about $1.1 \times 10^{6}$ short tons $\left(1 \times 10^{6}\right.$ metric tons $)$ of stripping coal in part of the Jarvis Creek coalfield. Barnes (1967a) originally estimated indicated and inferred coal resources based on coal beds greater than $2.5 \mathrm{ft}(0.75 \mathrm{~m})$ thick in the Jarvis Creek coalfield to be about 51 million short tons (46 million metric tons) between 0 and 1,000 ft (0-305 m) of overburden and about 26 million short tons ( 24 million metric tons) between 1,000 and $2,000 \mathrm{ft}$ (305-609 m) of overburden.

A small coal strip mine was opened in the center of the Jarvis Creek coalfield in 1958, and mining continued sporadically for many years; more than 1 million short tons $(0.9$ million metric tons) was estimated as strippable reserve in a 40-acre site (16 hectares) near the old mine by Metz (1981). At the mine, individual coal beds range from 1 to $10 \mathrm{ft}$ ( 0.3 to $3 \mathrm{~m}$ ) thick, and seven beds exceed $6 \mathrm{ft}(1.8 \mathrm{~m})$, four of which were mined at the surface (Belowich, 1987). The minable coal beds are plotted in figure 39, which shows an 11-ft-thick $(3.4 \mathrm{~m})$ coal separated by a 4 -ft-thick $(1.2 \mathrm{~m})$ carbonaceous shale parting that, west and east of RGD1, splits this coal into two separate beds (B and C), each averaging 7-8 ft (2.1-2.4 $\mathrm{m}$ ) thick (Belowich, 1987). The intervening strata are fluvial channel sandstones and flood plain overbank deposits.

In the Wood River coalfield (fig. 19), Merritt (1987) mapped the Usibelli Group from the Healy Creek Formation 
to the Grubstake Formation. However, he identified minable coal beds only within a 600 -ft-thick $(183 \mathrm{~m})$ coal-bearing interval of the Suntrana Formation. The coal-bearing Usibelli Group underlies a $>40-\mathrm{mi}^{2}\left(103-\mathrm{km}^{2}\right)$ area that makes up the Wood River coalfield, where individual Suntrana coal beds are as much as $12 \mathrm{ft}(3.7 \mathrm{~m})$ thick. The coal beds considered as minable include an aggregate coal thickness of $50 \mathrm{ft}$ (15 $\mathrm{m})$ thick of which $30 \mathrm{ft}(9.1 \mathrm{~m})$ is recoverable, and overburden was limited to less than $500 \mathrm{ft}(150 \mathrm{~m})$. Utilizing all coal beds greater than or equal to $2.5 \mathrm{ft}(0.75 \mathrm{~m})$, Merritt (1987) estimated indicated coal resources (high assurance) to be 65 million short tons (59 million metric tons) and hypothetical coal resources (low assurance) to be as much as 200 million short tons (181 million metric tons). Barnes (1967a) originally estimated coal resources based on coal beds greater than 2.5 $\mathrm{ft}(0.75 \mathrm{~m})$ thick in the Wood River coalfield as: 15 million short tons (13.6 million metric short tons) of measured with 0-1,000 ft (0-305 m) of overburden; 12 million short tons (11 million metric tons) of indicated with $0-1,000 \mathrm{ft}(0-305 \mathrm{~m})$ of overburden; and 241 million short tons (218 million metric short tons) of inferred with $0-1,000 \mathrm{ft}(0-305 \mathrm{~m})$ of overburden. Indicated coal resources under 1,000 to 3,000 ft (305-914 m) of overburden were estimated by Barnes (1967a) to be 33 million short tons (30 million metric tons).

Barnes (1967a) estimated the indicated and inferred coal resources in the Rex Creek coalfield (see fig. 19) based on coal beds greater than $2.5 \mathrm{ft}(0.75 \mathrm{~m})$ thick to be 9.5 and 113.5 million short tons (8.6 and 103 million metric tons) with $0-1,000 \mathrm{ft}(0-305 \mathrm{~m})$ of overburden, respectively. Total coal resources, based on coal beds greater than $2.5 \mathrm{ft}(0.75$ $\mathrm{m})$ thick, are about 123 million short tons (111 million metric tons).

Indicated and inferred coal resources of the Tatlanika Creek coalfield (see fig. 19) were estimated by Barnes (1967a) to be about 117 and 77 million short tons (106 and 70 million metric tons) with $0-1,000 \mathrm{ft}(0-305 \mathrm{~m})$ of overburden, respectively. Inferred coal resources from 1,000 to $2,000 \mathrm{ft}$ (305 to $610 \mathrm{~m}$ ) of overburden are about 76 million short tons (69 million metric tons). Total coal resources based on coal beds greater than $2.5 \mathrm{ft}(0.75 \mathrm{~m})$ thick are about 270 million short tons (245 million metric tons) with $0-2,000 \mathrm{ft}(0-610 \mathrm{~m})$ of overburden.

Coal resources for the 10 coalfields of the Central Alaska-Nenana coal province were estimated by Merritt and Hawley (1986) to be 8 billion short tons ( 7.2 billion metric tons) identified and 15 billion short tons (14 billion metric tons) hypothetical. Barnes (1967a) estimated about 6.2 billion short tons ( 5.6 billion metric tons) of identified coal resources in this coal province (table 4 ).

\section{Coal Quality}

Coal in the Central Alaska-Nenana coal province ranges from lignite to subbituminous but is mainly subbituminous C (table 5). In the Usibelli Coal Mine the coal is subbitumi- nous with 7,570-9,430 Btu/lb (4,210-5,240 kcal/kg) on an as-received basis, 17.8 percent moisture content, 3.5-13.2 percent ash yield, and 0.1-0.3 sulfur (Barnes, 1967a). The sulfur content of the Usibelli coal ranks among the lowest of any United States coal (Rao and Wolff, 1981; Affolter and others, 1981). Affolter and others (1994) reported that the Usibelli mine coal contains high concentrations of lead and selenium and low concentrations of beryllium and mercury, all of which are designated as hazardous air pollutants (HAPs) by the 1990 Clean Air Act Amendment.

In general, a typical coal in the Healy Creek and Lignite Creek coalfields ranges from 6,130 to $9,210 \mathrm{Btu} / \mathrm{lb}(3,410$ to $5,120 \mathrm{kcal} / \mathrm{kg})$ with a mean of $7,780 \mathrm{Btu} / \mathrm{lb}(4,320 \mathrm{kcal} / \mathrm{kg})$; ash yield is from 5.2 to 34.5 percent (mean is 9.9 percent); sulfur is from 0.1 to 1.49 percent (mean is 0.27 percent); and moisture content ranges from 14.8 to 32.7 percent (mean is 24.7 percent) (Affolter and others, 1994).

Coal in the Jarvis Creek coalfield (see fig. 19) ranges mainly from 7,820 to $9,420 \mathrm{Btu} / \mathrm{lb}(4,340$ to $5,230 \mathrm{kcal} / \mathrm{kg})$; ash yield is from 5.2 to 13.1 percent; sulfur content is from 0.3 to 1.4 percent; and moisture content is from 20 to 23 percent (as-received basis; Barnes, 1967a). However, coal beds in the vicinity of the Jarvis Creek coal mine range, on an as-received basis, from 6,550 to $10,000 \mathrm{Btu} / \mathrm{lb}(3,640$ to $5,560 \mathrm{kcal} / \mathrm{kg})$; ash yield from 2.56 to 32.44 percent; sulfur content from 0.30 to 1.83 percent; and moisture content from 15.90 to 27.62 percent (Belowich, 1987). In addition, the coal beds contain low concentrations of trace elements (for example, chromium, beryllium, cadmiun, and cobalt) recognized as HAPs in the 1990 Clean Air Act Amendment.

In the Wood River coalfield (see fig. 19), coals range from 7,240 to $9,380 \mathrm{Btu} / \mathrm{lb}(4,020$ to $5,210 \mathrm{kcal} / \mathrm{kg}$ ) (asreceived basis); ash yield from 1.81 to 16.31 percent (asreceived basis); sulfur content from 0.19 to 0.73 percent (as-received basis); and moisture content from 18.03 to 27.57 percent (as received basis) (Merritt, 1987).

\section{Coal Petrology}

Petrology of the coal beds in the Jarvis Creek and Wood River coalfields exhibits three main maceral compositions: huminite (vitrinite), liptinite, and inertinite. At Jarvis Creek, the huminite varies from 62.0 to 88.8 percent, liptinite from 10 to 18.5 percent, and inertinite from 2.2 to 6.5 percent (Belowich, 1987). In contrast, in the Wood River coalfield the huminite varies from 77.7 to 93.9 percent, liptinite from 4.7 to 20.3 percent, and inertinite from 0.2 to 9.1 percent (Merritt, 1987). The abundant woody materials preserved as huminites in the coal beds of the Wood River coalfield suggest that the coal formed mainly from trees. The variable inertinite composition of the coal beds in the Wood River coalfield, indicates that the woody mires were not much affected by forest fires but more by fluctuating ground-water levels and fungal attack (Belowich, 1987). The higher huminite content of the coal beds in the upper part of the coal-bearing interval in the Wood 
River suggests that the mire vegetation evolved through time with the increase of coniferous trees relative to deciduous trees (Merritt, 1987).

\section{Southern Alaska-Cook Inlet Coal Province}

The Southern Alaska-Cook Inlet coal province is a large coal-bearing region that is as much as $100 \mathrm{mi}(161 \mathrm{~km})$ wide and $225 \mathrm{mi}(362 \mathrm{~km})$ long and covers an area about 22,500 $\mathrm{mi}^{2}\left(58,275 \mathrm{~km}^{2}\right)$, half of which is beneath the waters of Cook Inlet (fig. 1). Many of the Tertiary coal-bearing rocks in the Southern Alaska-Cook Inlet Basin lie beneath the Cook Inlet, Susitna Lowland, Broad Pass Depression, Matanuska Valley, and Kenai Peninsula. In this coal province, Barnes (1967a) identified four coalfields containing Tertiary coal deposits - the Broad Pass, Susitna-Beluga, Matanuska, and Kenai coalfields (fig. 40). Although these Tertiary coal-bearing coalfields occur in onshore areas bordering the Cook Inlet, this report will also describe equivalent Tertiary coal-bearing rocks offshore in the Cook Inlet.

The Southern Alaska-Cook Inlet coal province is centered on the deep trough in the arc-trench gap between the Aleutian volcanic arc and the Aleutian Trench (Fisher and Magoon, 1978). The Cook Inlet Basin, which includes the onshore coalfields and offshore Cook Inlet, lies in the northwesternmost part of this arc-trench gap. The basin, which contains the Southern Alaska-Cook Inlet coal province, is a subsiding, fore-arc basin that lies on the site of a middle Mesozoic open shelf between a volcanic arc and an ancient Pacific oceanic crust (fig. 41; Wahrhaftig and others, 1994). The Lower Jurassic Talkeetna Formation and the Middle Jurassic Talkeetna batholith on the north of the basin represent the volcanic arc (fig. 3). The Kenai and Chugach Mountains represent the ancient Pacific oceanic crust south and east of the basin. Thick Tertiary coal-bearing rocks (Paleocene to Pliocene) overlie

Table 5. Coal quality of coal deposits in the Tertiary Usibelli Group in the Central Alaska-Nenana coal province.

[All analyses except Calorific value (Btu) and Ash-fusion-temperature ( ${ }^{\circ} \mathrm{F}$ ) are in percent. Values reported on an as-received basis. $L$ after a value means less than the value shown]. Data from U.S. Geological Survey, 1997, USGS Coal Quality Database (USCHEM) (unpublished computer database: Reston, Virginia)]

\begin{tabular}{|c|c|c|c|c|c|c|}
\hline \multirow{2}{*}{ Unit } & \multirow{2}{*}{ Parameter } & \multirow{2}{*}{$\begin{array}{c}\text { Number } \\
\text { of } \\
\text { samples }\end{array}$} & \multicolumn{2}{|c|}{ Range } & \multirow{2}{*}{$\begin{array}{l}\text { Arithmetic } \\
\text { mean }\end{array}$} & \multirow{2}{*}{$\begin{array}{l}\text { Standard } \\
\text { deviation }\end{array}$} \\
\hline & & & Minimum & Maximum & & \\
\hline \multirow{20}{*}{ 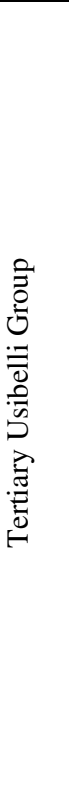 } & \multicolumn{6}{|c|}{ Proximate and ultimate analysis } \\
\hline & Moisture & 30 & 14.80 & 32.70 & 24.70 & 4.97 \\
\hline & Volatile matter & 30 & 27.30 & 40.10 & 35.89 & 2.82 \\
\hline & Fixed carbon & 30 & 23.10 & 34.10 & 29.52 & 3.23 \\
\hline & Ash yield & 30 & 5.20 & 34.50 & 9.89 & 5.49 \\
\hline & Hydrogen & 30 & 4.60 & 6.90 & 6.11 & 0.58 \\
\hline & Carbon & 30 & 35.60 & 52.40 & 45.58 & 4.63 \\
\hline & Nitrogen & 30 & 0.50 & 1.00 & 0.67 & 0.12 \\
\hline & Oxygen & 30 & 24.50 & 44.60 & 37.48 & 4.73 \\
\hline & Sulfur & 206 & 0.01 & 1.49 & 0.27 & 0.24 \\
\hline & \multicolumn{6}{|c|}{ Calorific value } \\
\hline & Btu per pound & 30 & 6,130 & 9,210 & 7,780 & 910 \\
\hline & \multicolumn{6}{|c|}{ Forms-of-sulfur } \\
\hline & Sulfate & 206 & $0.01 \mathrm{~L}$ & 0.14 & 0.01 & 0.01 \\
\hline & Pyritic & 160 & $0.01 \mathrm{~L}$ & 0.55 & 0.05 & 0.08 \\
\hline & Organic & 160 & $0.01 \mathrm{~L}$ & 0.90 & 0.21 & 0.21 \\
\hline & \multicolumn{6}{|c|}{ Ash-fusion-temperatures ${ }^{\circ} \mathrm{F}$} \\
\hline & Initial deformation & 22 & 1,970 & 2,320 & 2,170 & 100 \\
\hline & Softening temperature & 22 & 2,050 & 2,420 & 2,250 & 120 \\
\hline & Fluid temperature & 69 & 2,150 & 2,530 & 2,330 & 130 \\
\hline
\end{tabular}


a thick, Middle Jurassic to Upper Cretaceous, terrigenous, epiclastic sequence, which accumulated on this shelf (Kirschner and Lyon, 1973; Fisher and Magoon, 1978). The McHugh Complex and the Valdez Group, which are oceanic crust and deep-sea turbidite sequences, were accreted to southern Alaska during Late Cretaceous time to form the Chugach and Kenai Mountains. This accreted terrane widened the arc-trench gap, which is now about $280 \mathrm{mi}(450 \mathrm{~km})$ wide. Irregular subsidence of the fore-arc basin began in latest Cretaceous time and continued sporadically throughout Cenozoic time. Basin subsidence, which was interrupted by mild uplift and erosion, was greatest during Neogene time in a 155 -mi-long $(250-\mathrm{km})$ segment of Cook Inlet in much of central and southern Alaska.
Swenson (1997) proposed, based on studies by Richard Curry, David Doherty, and Joseph McGowen (Atlantic-Richfield Company, oral commun., 1998), that the Hemlock, Tyonek, Beluga, and Sterling Formations of the Kenai Group and the West Foreland Formation are regionally time-transgressive units (fig. 42). In addition, these workers suggested that the rock units are laterally equivalent facies related to a dynamic nonmarine depositional basin. That is, the coarsest facies (conglomerates and sandstones) were deposited proximal to the source by an alluvial fan system, which transported sediments from the uplifted Aleutian volcanic arc and accretionary complex margins (Joseph McGowen, Atlantic-Richfield Company,

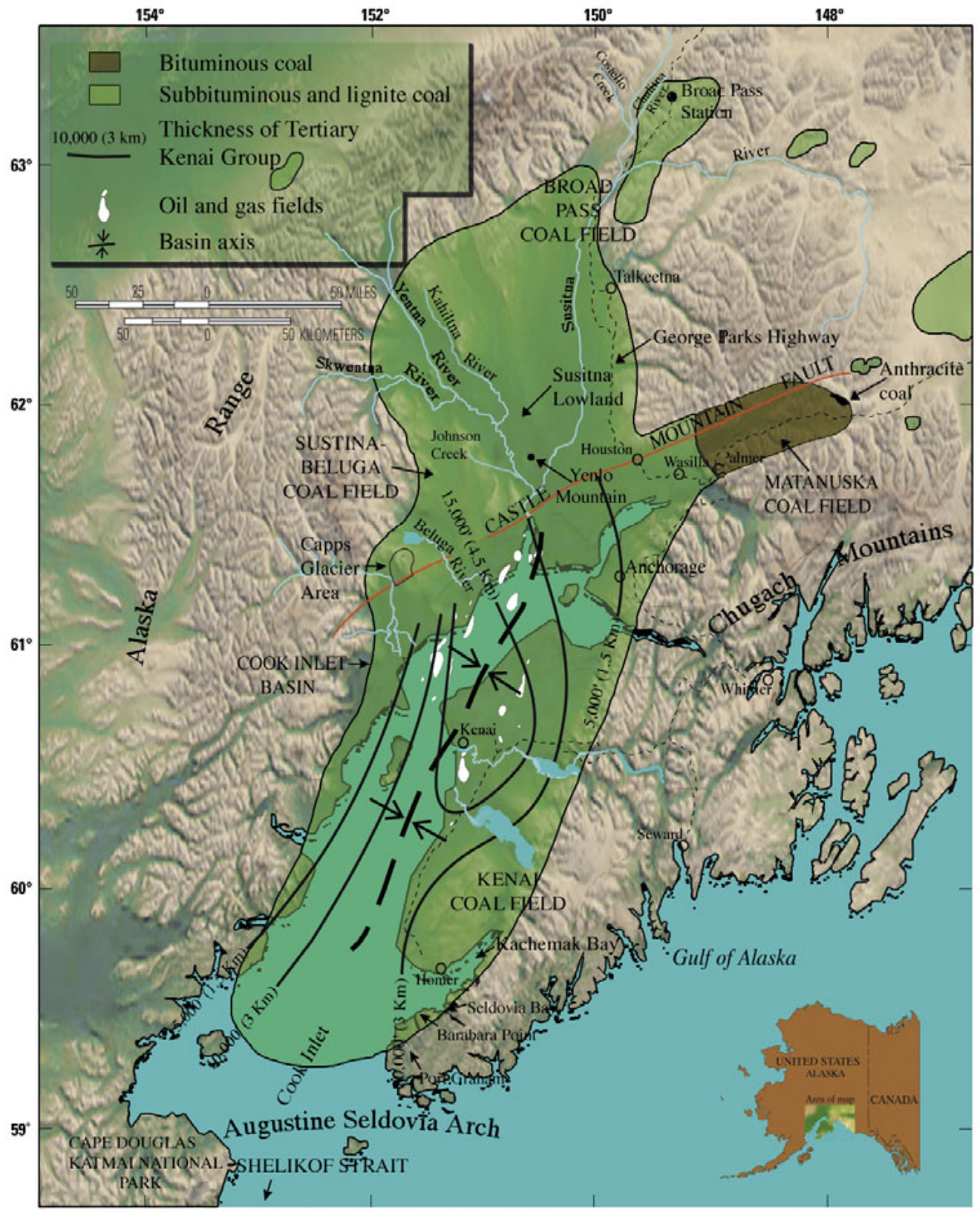

Figure 40. Map showing coalfields in the Southern Alaska-Cook Inlet coal province. 
oral commun., 1998). The distal depositional system in the basin center consisted of an axial-fluvial system that reworked the alluvial fan deposits and migrated across the basin floor in relation to uplift and sediment input (fig. 43). Mires, where plant material accumulated, developed within the axial fluvial system.

The Tertiary coal-bearing rocks in the Southern AlaskaCook Inlet coal province accumulated in the subsiding Cook Inlet Basin, which was probably drained by a large, fluvial, trunk-tributary and alluvial fan system that flowed into the Pacific (Kirschner, 1988). Alluvial fans drained the basin margins, and the trunk (axial) stream drained a broad alluvial plain now occupied by the Cook Inlet. Two major tributary streams of the trunk river extended northward through the present Susitna Lowland and Broad Pass Depression and eastward through the present Matanuska Valley. A Susitna-Broad Pass tributary stream probably extended along the north side of the Alaska Range and drained the Central Alaska-Nenana coal province (Flores and Stanley, 1995). The Yukon-Tanana Upland may have been in headwaters of this tributary stream. Thus, all the coal deposits in the Central Alaska-Nenana and Southern Alaska-Cook Inlet coal provinces are thought to have accumulated in mires related to this large, integrated fluvial drainage system.

\section{Tertiary Rocks}

The bulk of the coal in the Southern Alaska-Cook Inlet coal province is of Oligocene to early Pliocene age (fig. 44). These late Tertiary coals are distributed in the Susitna-Beluga, Broad Pass, and Kenai coalfields. However, early Tertiary
(Paleocene and early Eocene) coal occurs in the Matanuska coalfield.

\section{Lower Tertiary Rocks}

The lower Tertiary rocks include the Paleocene-Eocene Chickaloon Formation and Eocene Wishbone Formation (fig. 45). The Chickaloon Formation is a 3,280- to 4,920-ft-thick (1,000-1,500 m) Paleocene to lower Eocene sequence of mudstones, siltstones, and sandstones, with minor conglomerates and coal beds (figs. 46, 47, and 48; Triplehorn and others, 1984; Flores and Stricker, 1993a). The formation rests unconformably on the Cretaceous Matanuska Formation, which is a sequence of marine sandstone and shale (Barnes and Payne, 1956; Grantz and Jones, 1960) and is overlain unconformably by the Eocene Wishbone Formation. The Wishbone consists of $2,950 \mathrm{ft}(900 \mathrm{~m})$ of thick, massive conglomerates and sandstones containing clasts derived from the Talkeetna Mountains to the north (figs. 49 and 50). The formation at the east end of the Matanuska coalfield is unconformably overlain by flatlying Tertiary basalt. Gabbro sills and dikes and other Tertiary volcanic rocks also intrude the coal-bearing Chickaloon Formation and increase the coal rank along the intrusive contact. The Wishbone Formation is equivalent to the coal-bearing West Foreland Formation in the south-southwest part of the Cook Inlet Basin. The West Foreland Formation consists of abundant conglomerates and sandstones and minor siltstones,

North

South

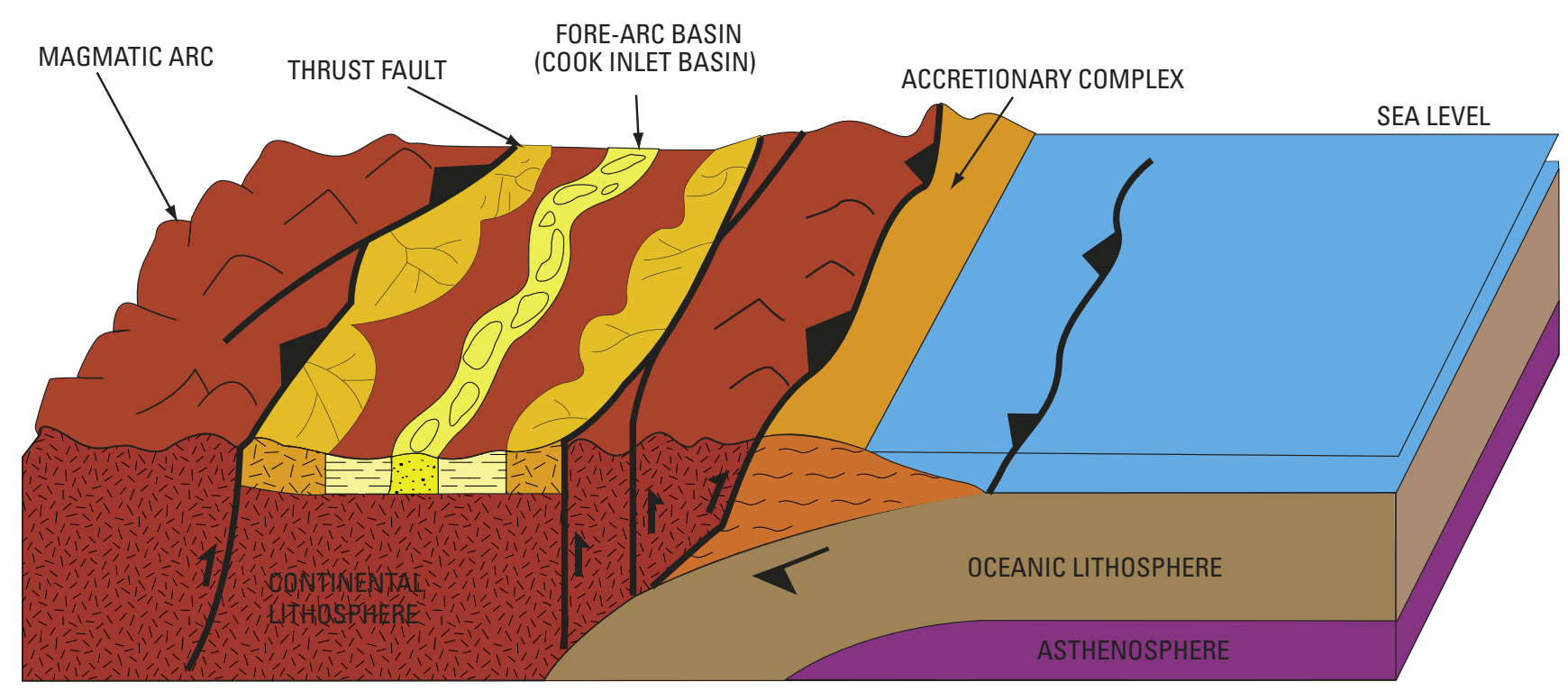

Figure 41. Tectonic and volcanic settings of the Cook Inlet Basin. Modified from McGowen and others in Swenson (1997). 


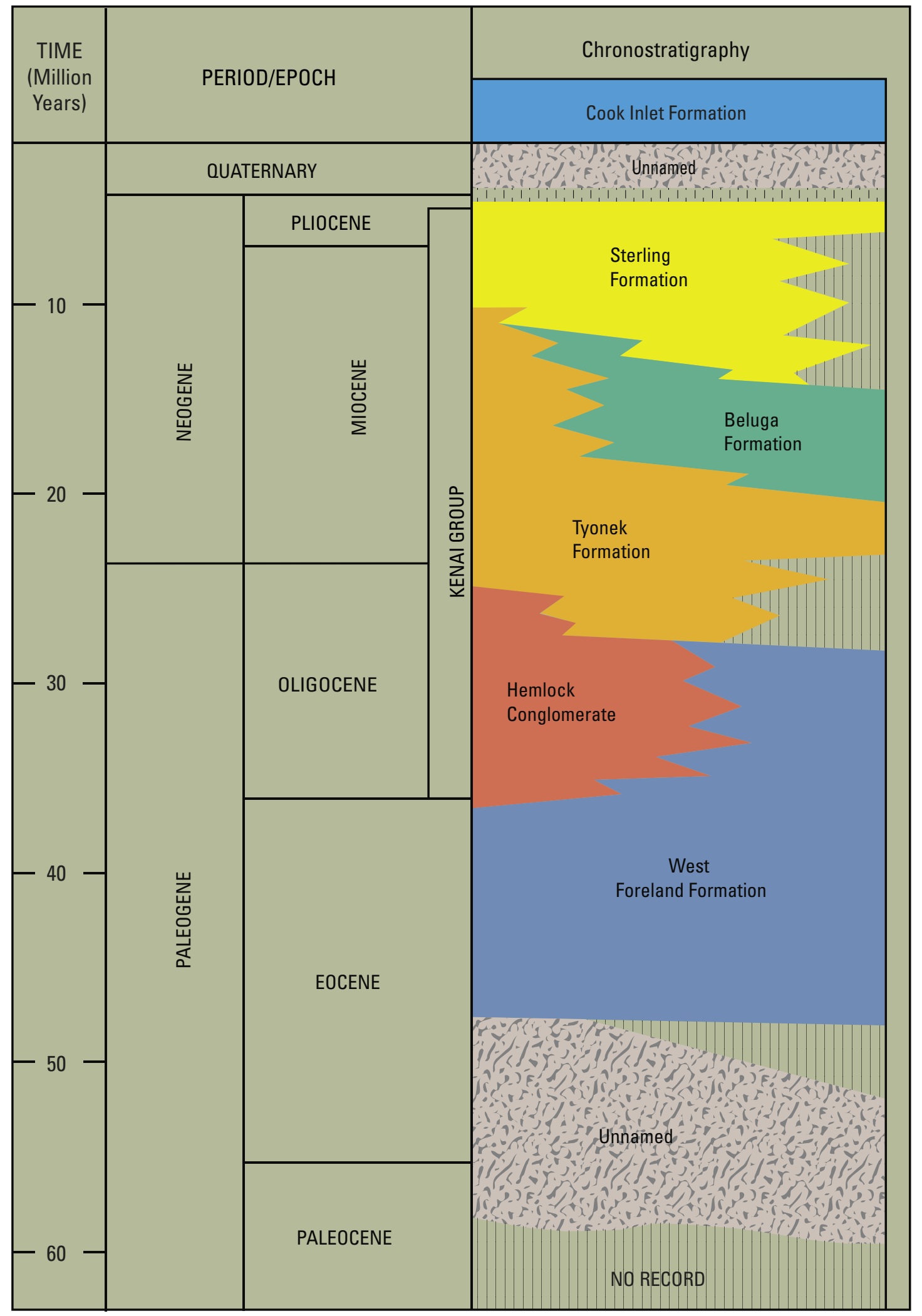

Figure 42. Generalized time-transgressive stratigraphy in the Cook Inlet Basin. Modified from McGowen and others in Swenson (1997). 
Cook Inlet Depositional Systems

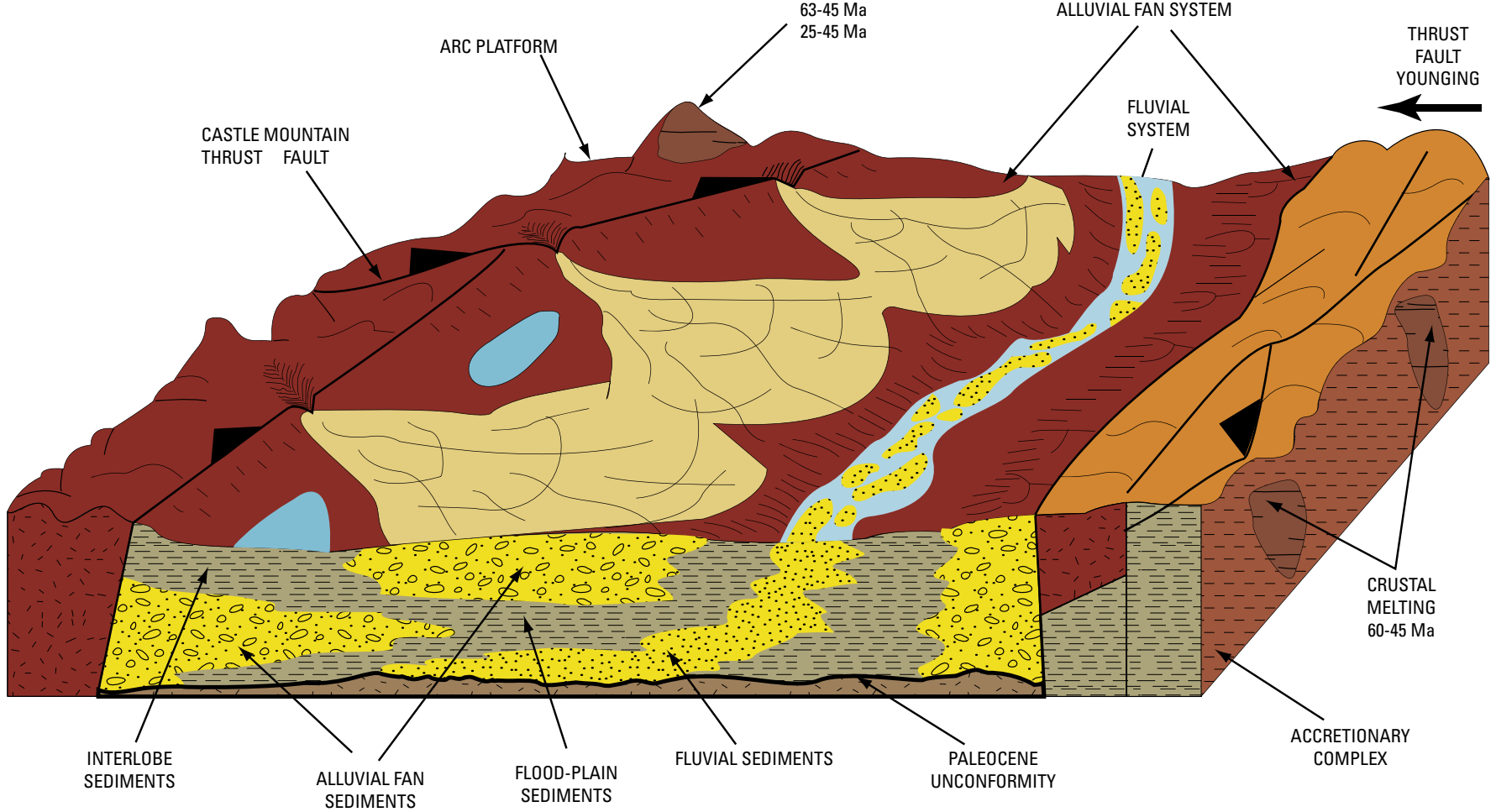

Figure 43. Depositional model of the Kenai Group in the Cook Inlet Basin. Modified from McGowen and others in Swenson (1997).

mudstones, and coal beds (Wahrhaftig and others, 1994).

Houston (1994) reported a few coal beds as thick as $1 \mathrm{ft}$ (30 $\mathrm{cm})$ in the 4,100-ft-thick (1,259 m) West Foreland Formation in the Cape Douglas-Katmai National Park area west of the Shelikof Strait and southeast of the Cook Inlet (see fig. 40).

Flores and Stricker (1993a, 1993d) described and interpreted the depositional environments of the Chickaloon and Wishbone Formations. Stratigraphic variations of the Chick- aloon sandstones, mudstones, and coal beds in the Wishbone Hill coal district are shown in figures 51, 52, 53, 54, 55, and 56. Sandstones are erosional based and range from lenticular (fig. 47) to tabular shape (fig. 48). Lenticular-shaped sandstones were deposited in fluvial channels and the tabularshaped sandstones were deposited in crevasse splays. Coal beds (fig. 46, a photograph of the upper part of the Chickaloon Formation in the Wishbone Hill coal district) of the Chick-

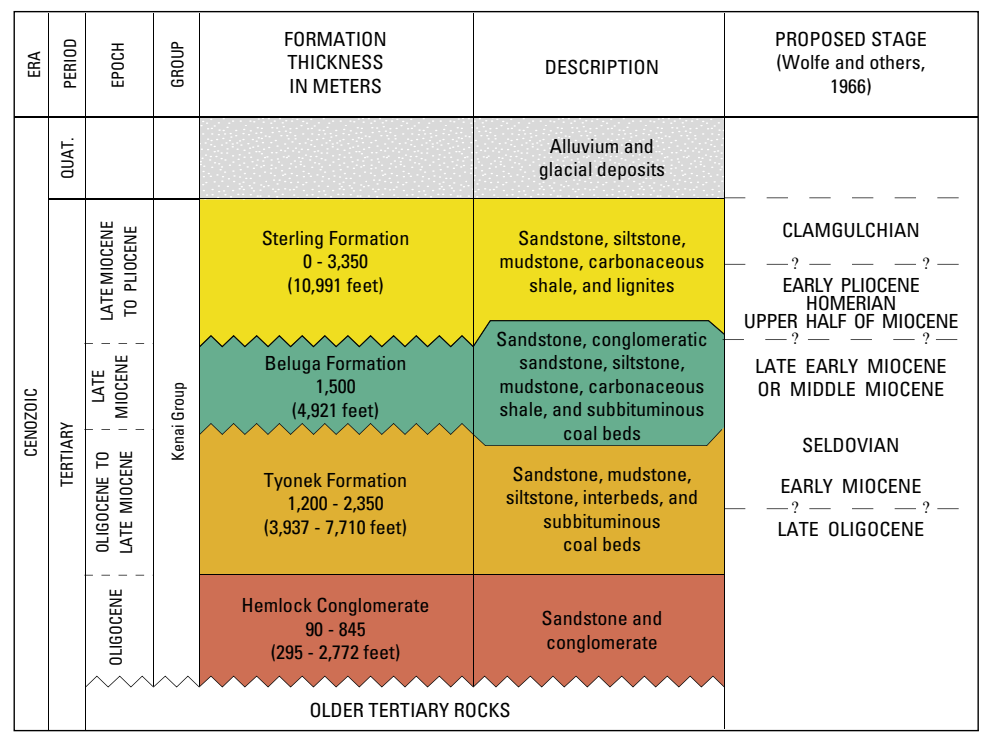

Figure 44. Generalized chronostratigraphic column of the coal-bearing Kenai Group and related rock units in the Southern Alaska-Cook Inlet coal province. 
aloon Formation were deposited in topogenous or low-lying mires associated with low-gradient bedload meandering (fig. 57) and anastomosed (fig. 57) fluvial systems. The low-lying mires formed on abandoned belts of meandering streams during lateral aggradation influenced by autocyclic processes. In contrast, low-lying mires related to anastomosed streams developed during vertical aggradation controlled by basin subsidence. Growth faulting promoted prolonged peat accumulation in mires on upthrown blocks and caused stream capture on downthrown blocks. The Wishbone Formation was deposited in alluvial fans and braided stream deposits that were shed from the Talkeetna Mountains (see fig. 57; Flores and Stricker, 1993d). The West Foreland Formation, an equivalent of the Wishbone Formation, was interpreted by Houston (1994) as being deposited in braided streams and associated flood plains. The sediments were derived mainly from the Alaska-Aleutian volcanic arc terrane. The West Foreland coal beds were deposited in abandoned braid belts and flood plains.

\section{Upper Tertiary Kenai Group}

The upper Tertiary rocks in the Southern Alaska-Cook Inlet coal province include the Kenai Group consisting, from bottom to top, of the Oligocene Hemlock Conglomerate, Oligocene to middle Miocene Tyonek, upper Miocene Beluga, and upper Miocene to Pliocene Sterling Formations (Flores and Stricker, 1993b, 1993c; Flores, Stricker, and Bader, 1997; Flores, Stricker, and Stiles, 1997; Flores and others, 1999). The Kenai Group is more than 25,000 ft (7,620 m) thick. All these formations are coal bearing, with the Tyonek and Beluga Formations containing numerous thick, minable coal beds. In the offshore and onshore Cook Inlet Basin (fig. 58) the Hemlock, Tyonek, Beluga, and Sterling Formations vary in thickness and lithostratigraphy (figs. 59, 60, and 61). Generally, the formations, especially the Tyonek and Beluga, thicken toward the central part of the basin. The Tyonek Formation is generally sandstone dominated toward the western part of the basin, the Beluga Formation is generally sandstone dominated toward the eastern part, and the Sterling Formation appears to be sandy in the central and eastern parts.
Figure 45. A generalized stratigraphic column of the Chickaloon and Wishbone Formations in the Matanuska coalfield. Minable coal zones occur in the uppermost part of the Chickaloon Formation. Modified from Flores and Stricker (1993a).

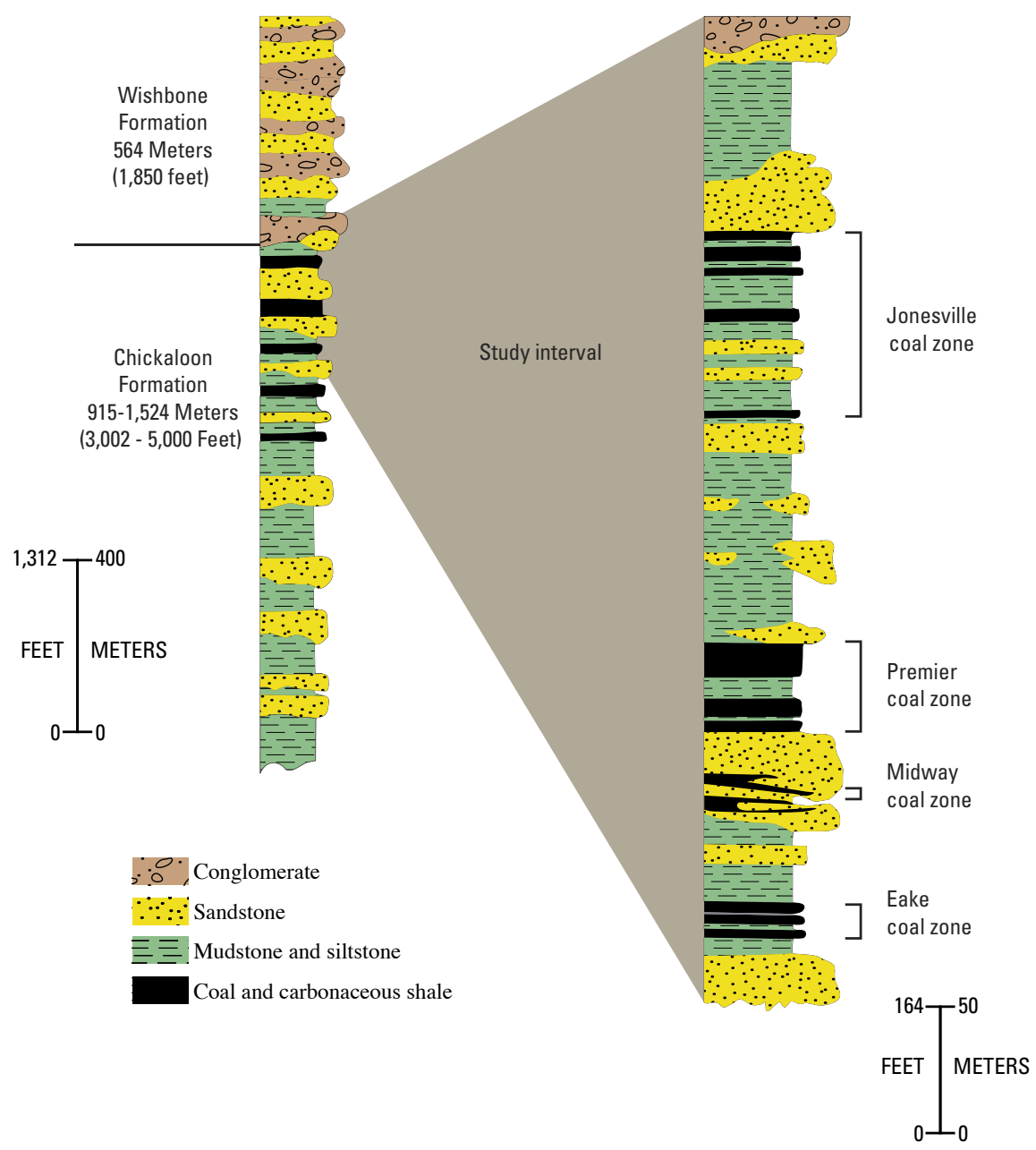




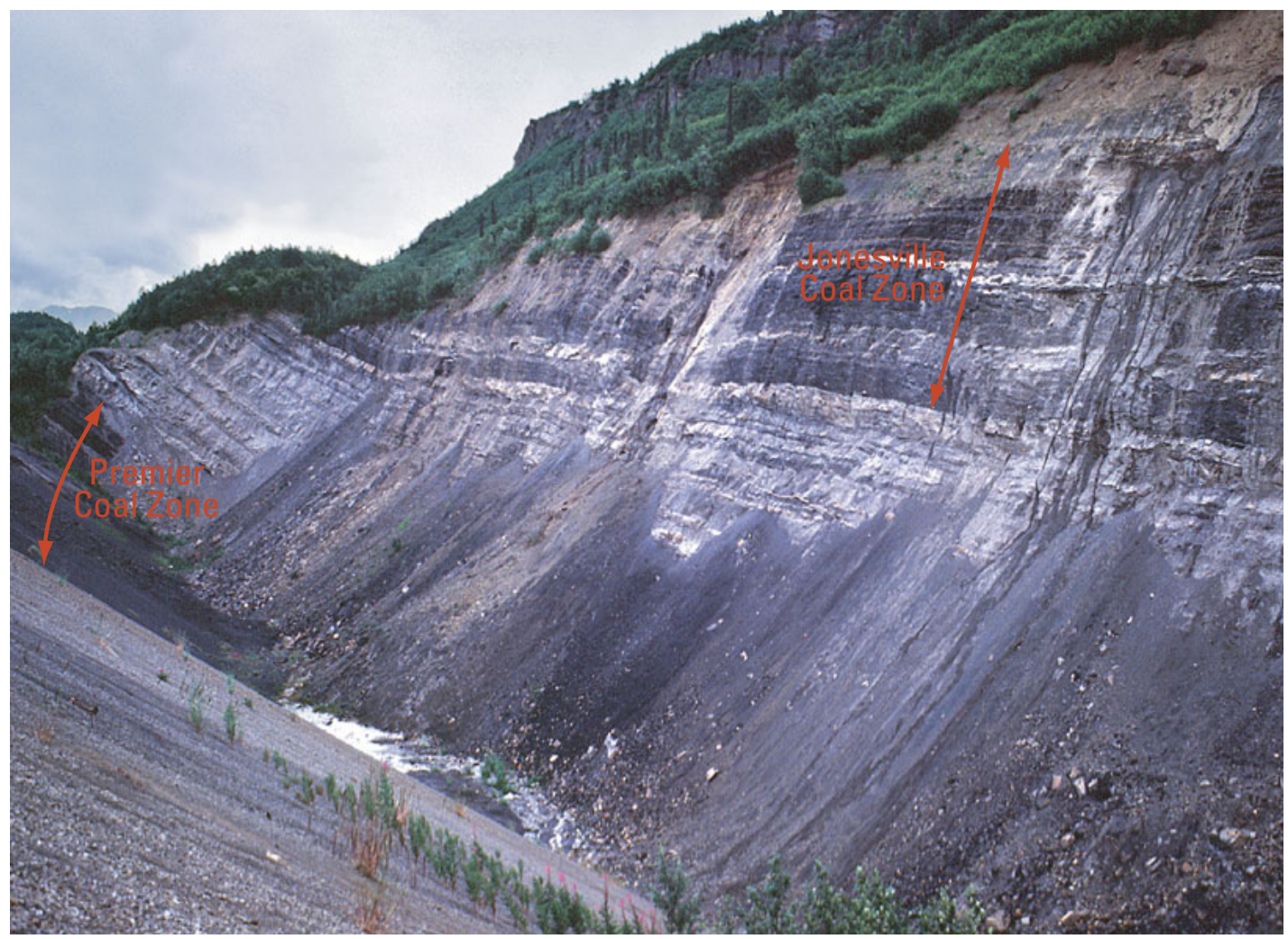

Figure 46. Photograph of coal beds of the Chickaloon Formation in the Wishbone Hill coal district. For scale, the Jonesville coal zone is 20 feet $(6.1$ meters) thick.

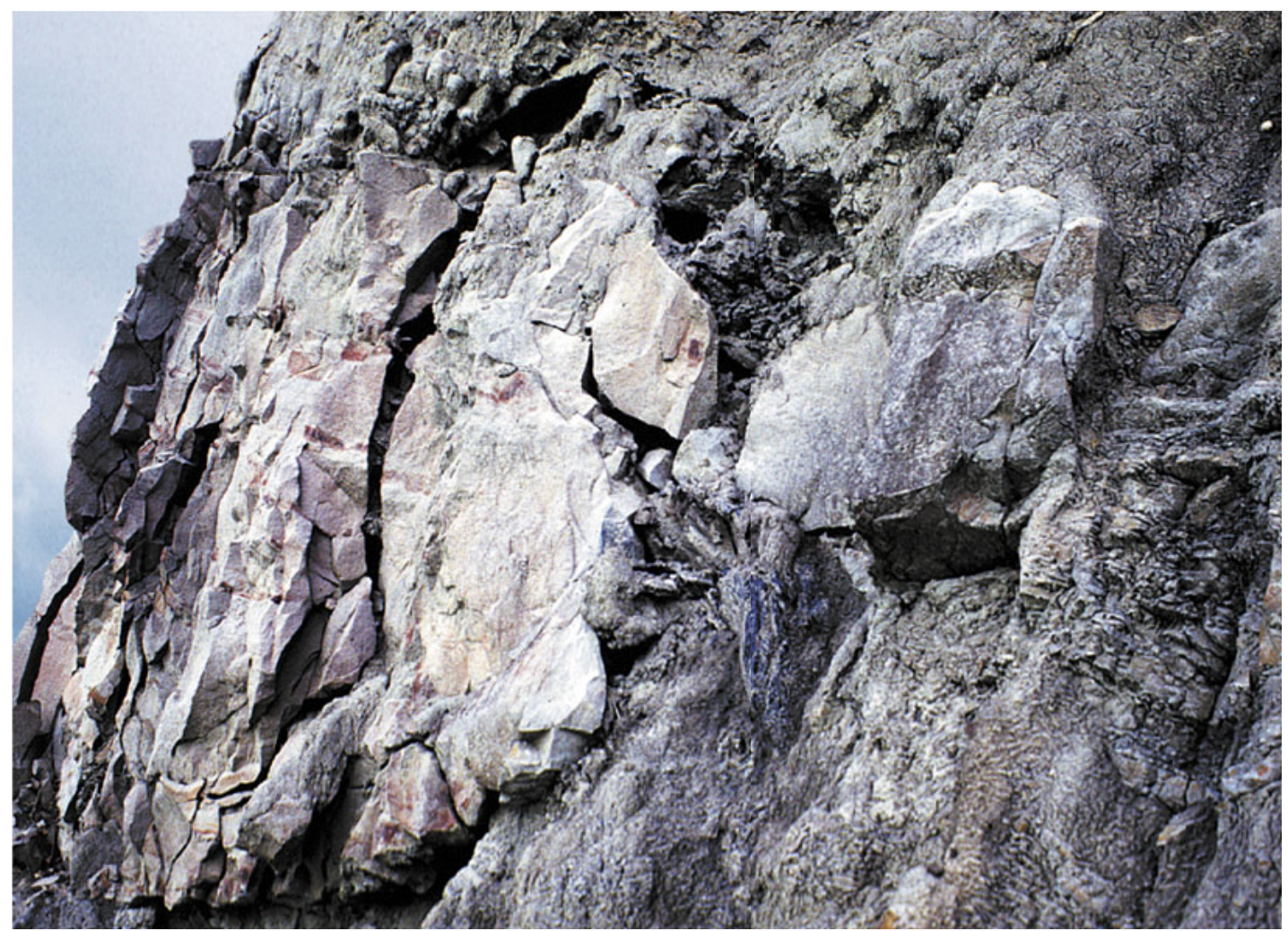

Figure 47. Photograph of the lenticular fluvial-channel sandstone (20 feet or 6.1 meters thick) and associated rocks of the Chickaloon Formation in the Wishbone Hill coal district. 


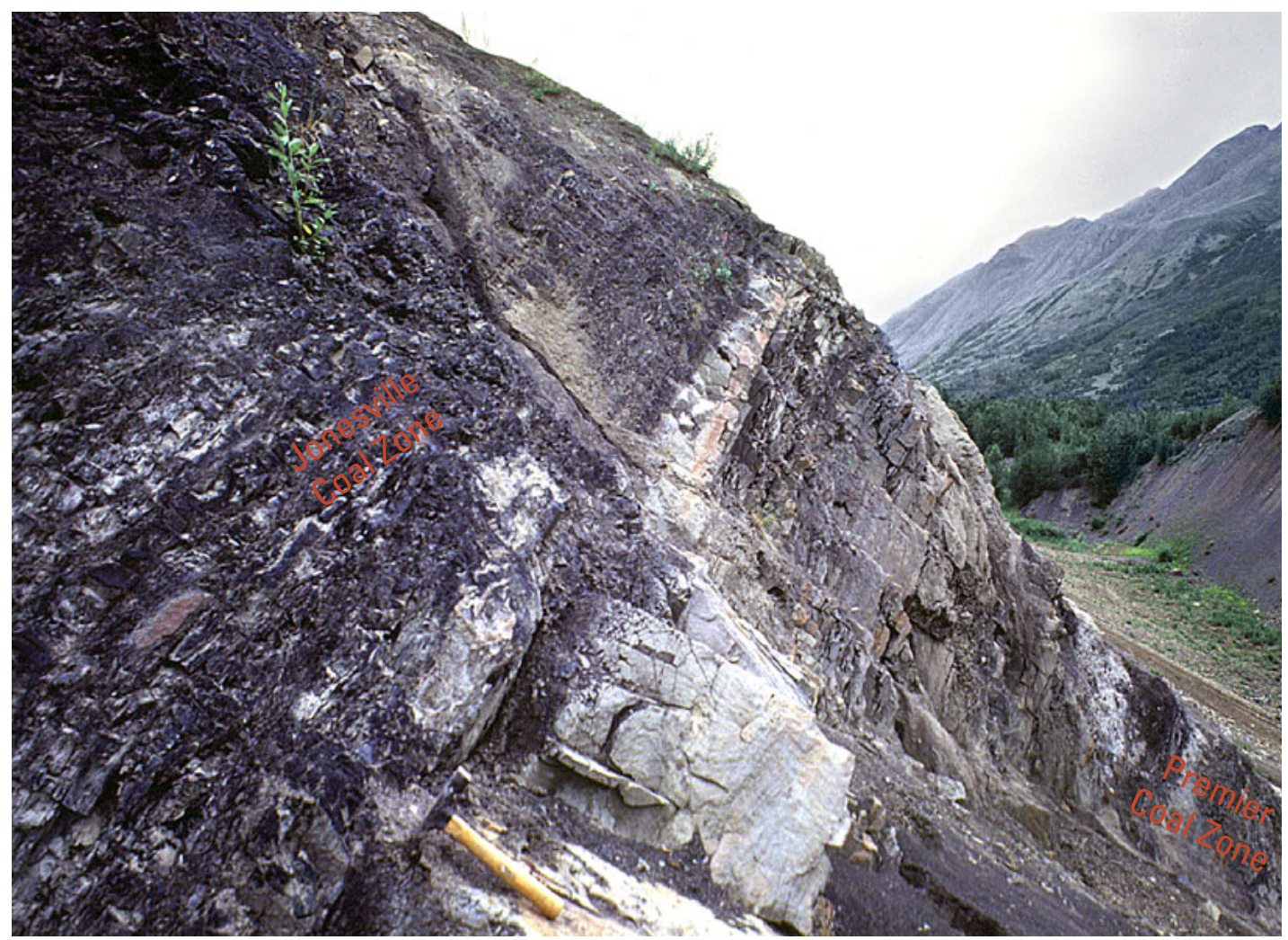

Figure 48. Photograph of the tabular crevasse splay sandstone and associated flood-plain deposits of the Chickaloon Formation in the Wishbone Hill coal district. Hammer in lower left is 1 foot (0.3 meter) long for scale.

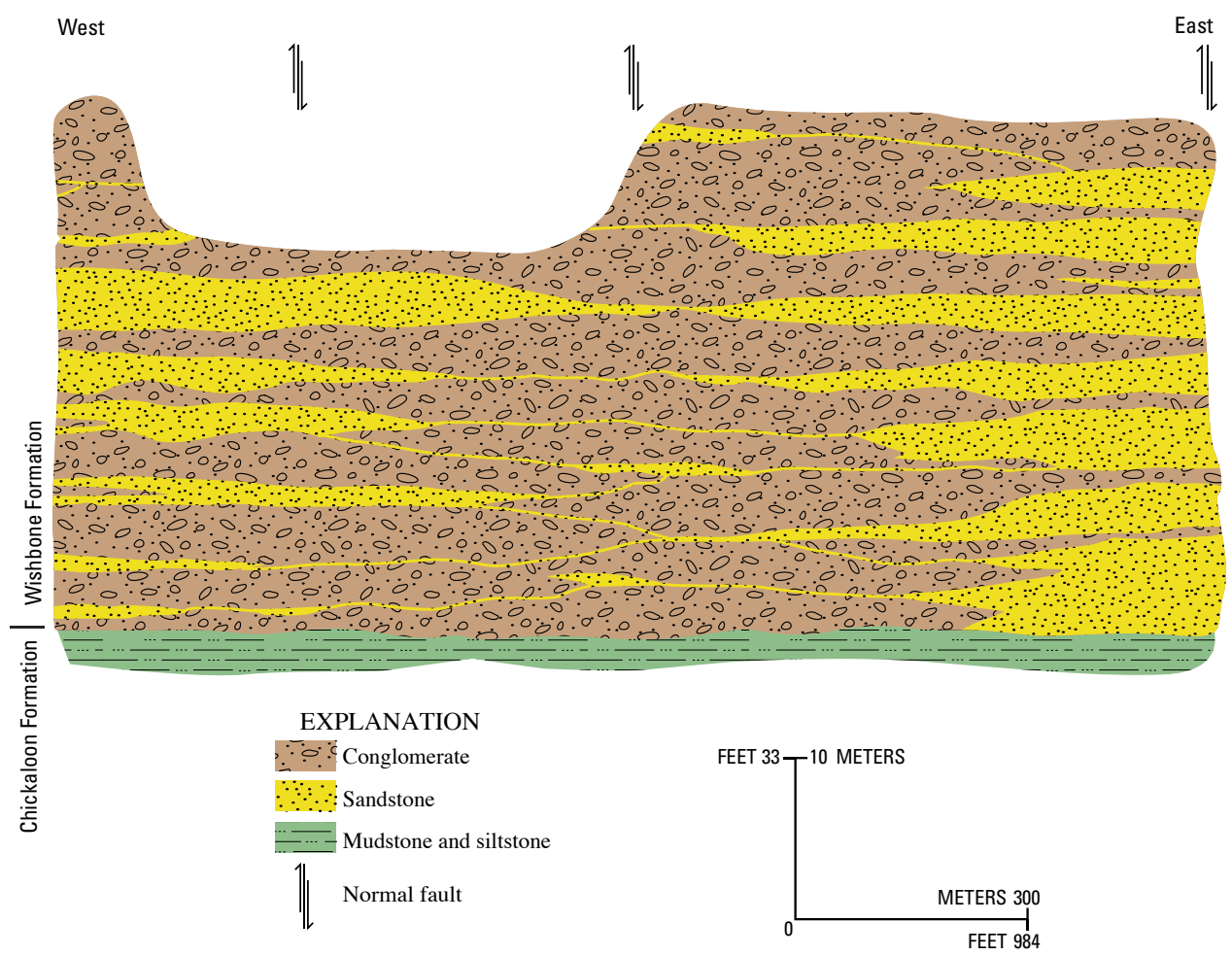

Figure 49. Vertical and lateral lithofacies variations of the Wishbone Formation in the Wishbone Hill coal district. 


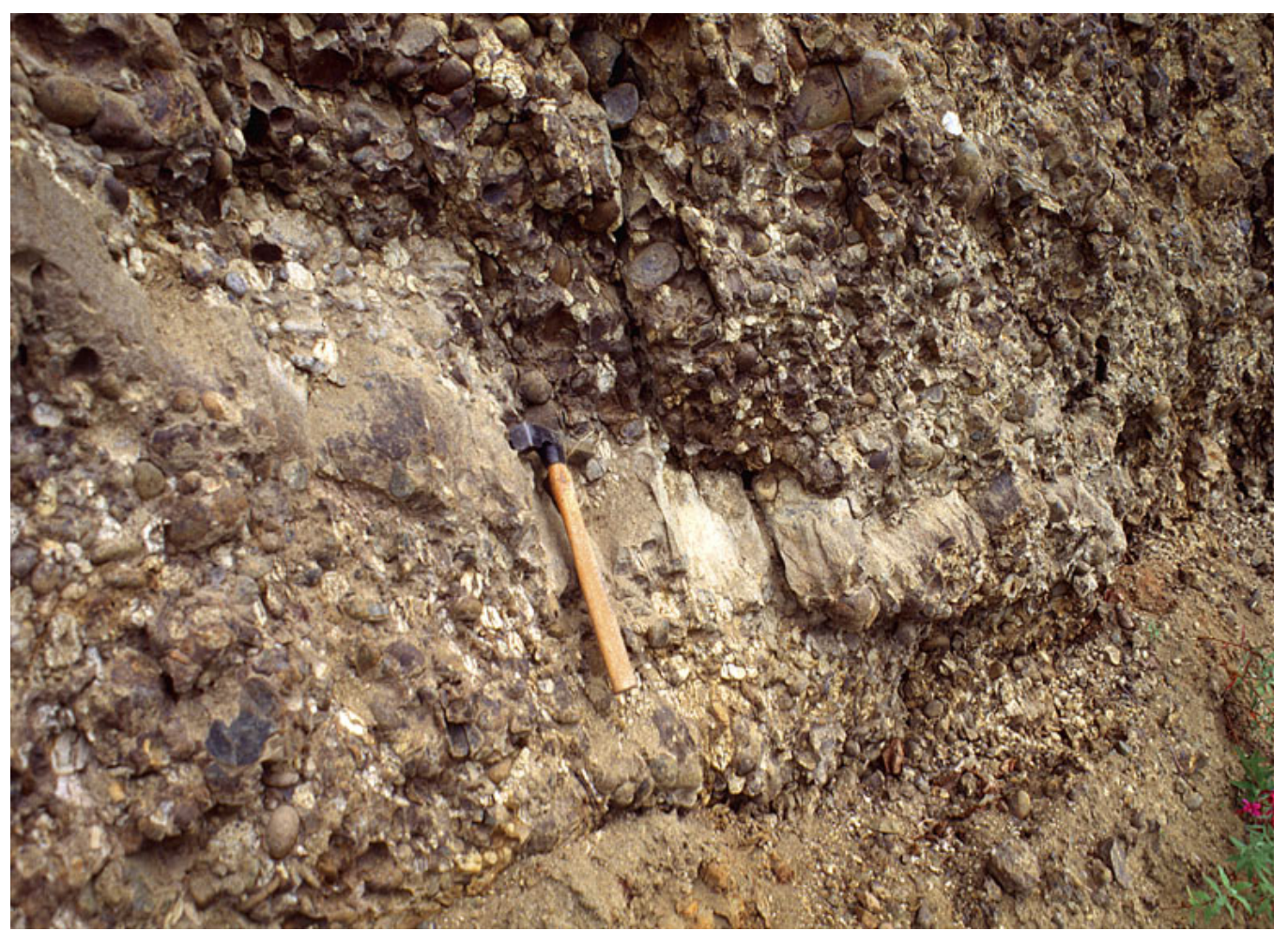

Figure 50. Photograph of the braided-stream-deposited conglomerates and sandstones in the Wishbone Formation in the Wishbone Hill coal district. Hammer is 1 foot (0.3 meter) long for scale.

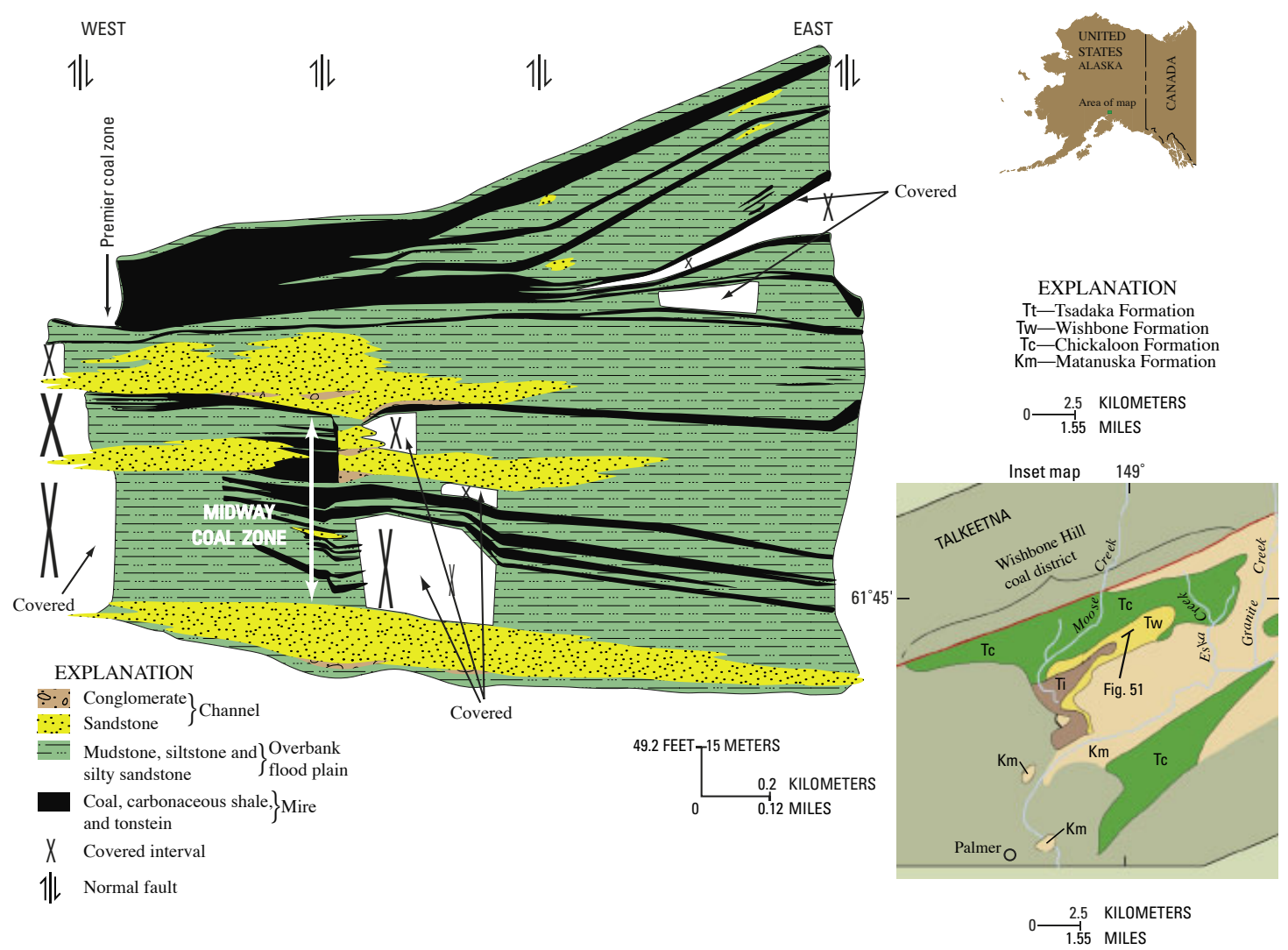

Figure 51. Stratigraphic cross section of the lower part of the Chickaloon Formation in the Wishbone Hill coal district. Adopted from Flores and Stricker (1993d). See inset map for location of cross section. 


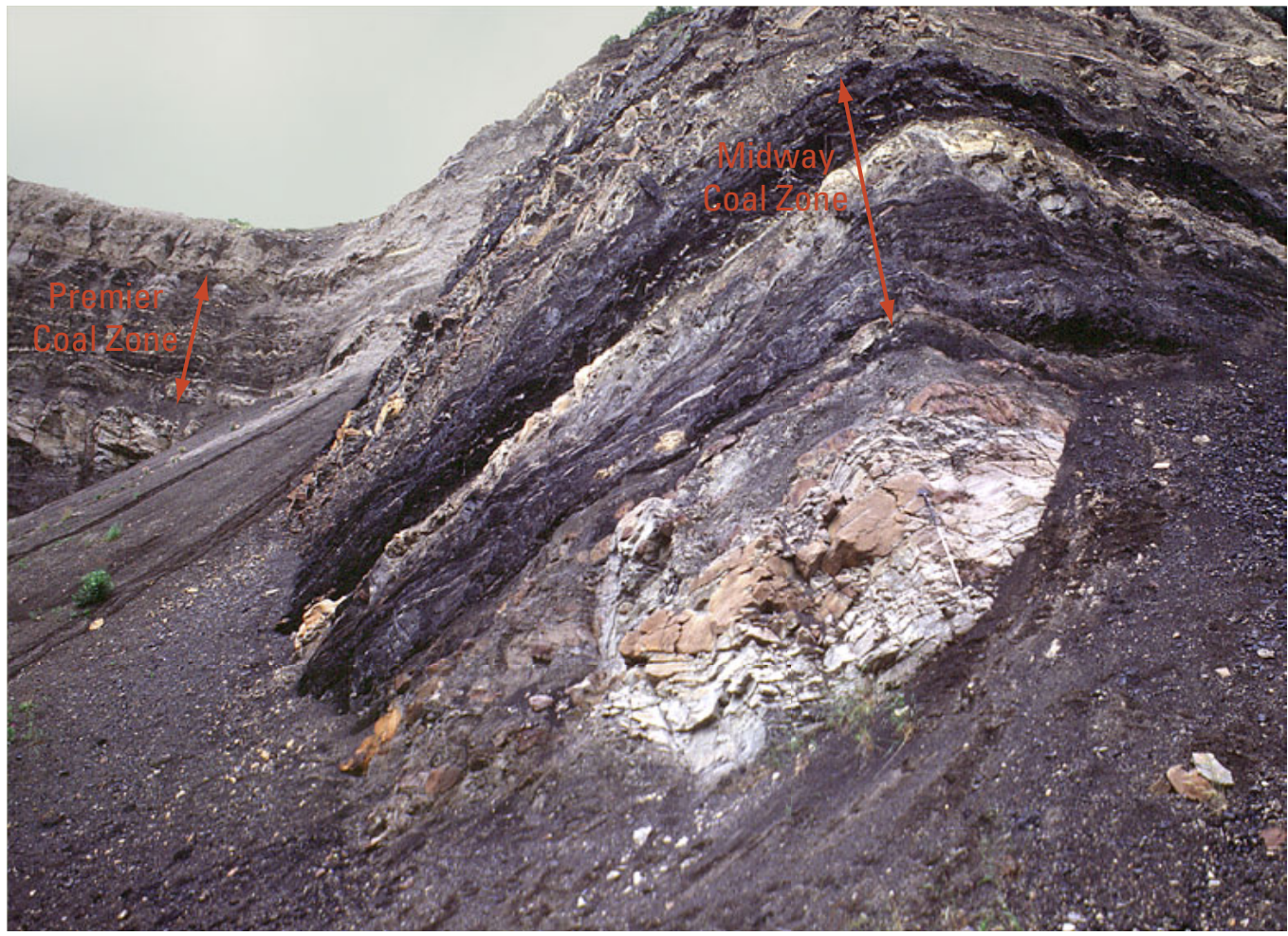

Figure 52. Photograph of the lower part of the Chickaloon Formation showing the Midway coal zone and adjoining fluvial-channel sandstones in the Wishbone Hill coal district. Jacob staff on the sandstone (see right side) is 5 feet ( 1.5 meters) for scale.

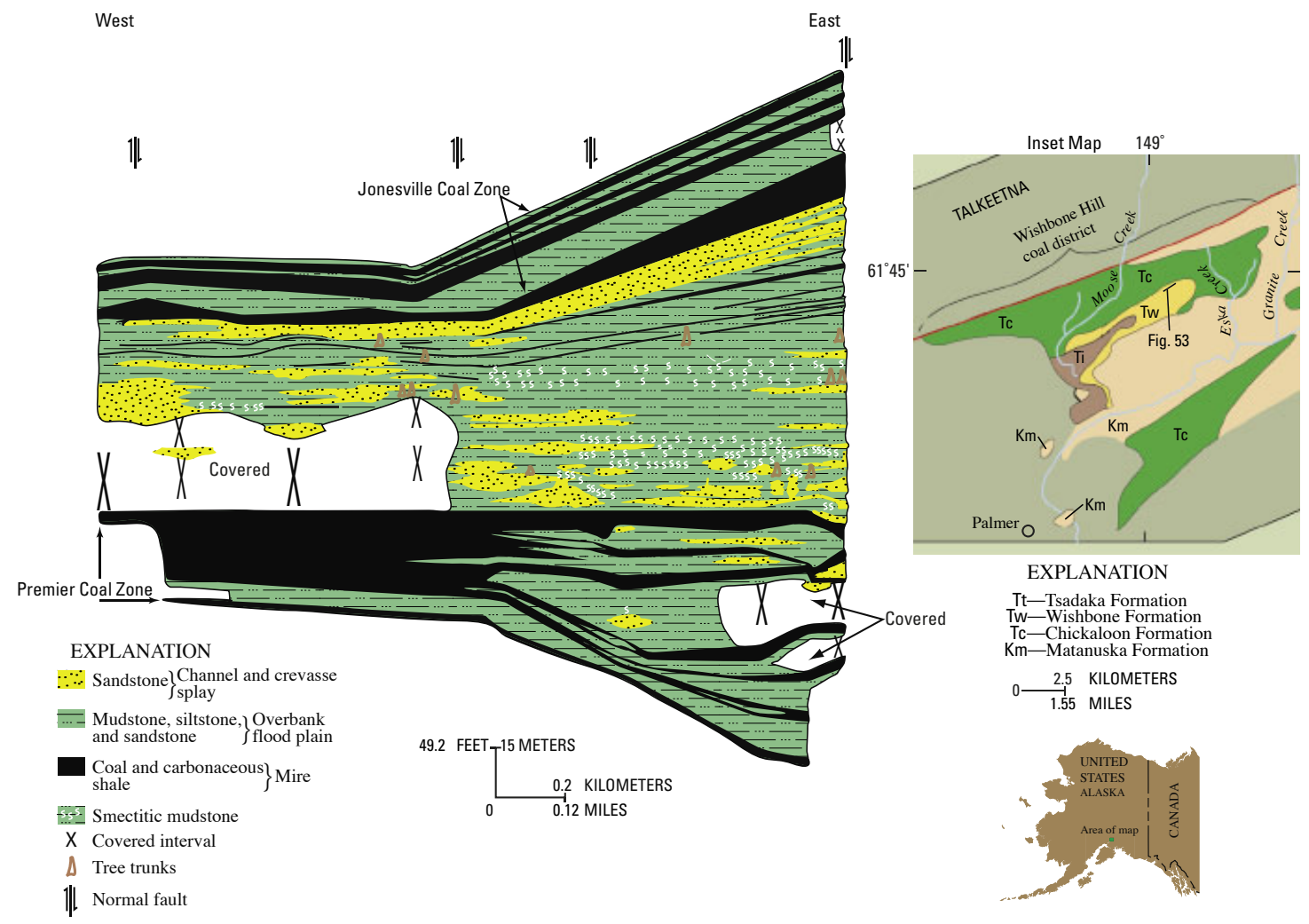

Figure 53. Stratigraphic cross section of the middle part of the Chickaloon Formation in the Wishbone Hill coal district. Adopted from Flores and Stricker (1993b). See inset map for location of cross section. 
Figure 54. Photograph of the upper part of the Chickaloon Formation showing the Premier coal zone (50 feet or 15.2 meters thick), Jonesville coal zone (30 feet or 9.1 meters thick) and associated finegrained sediments in the Wishbone Hill coal district.
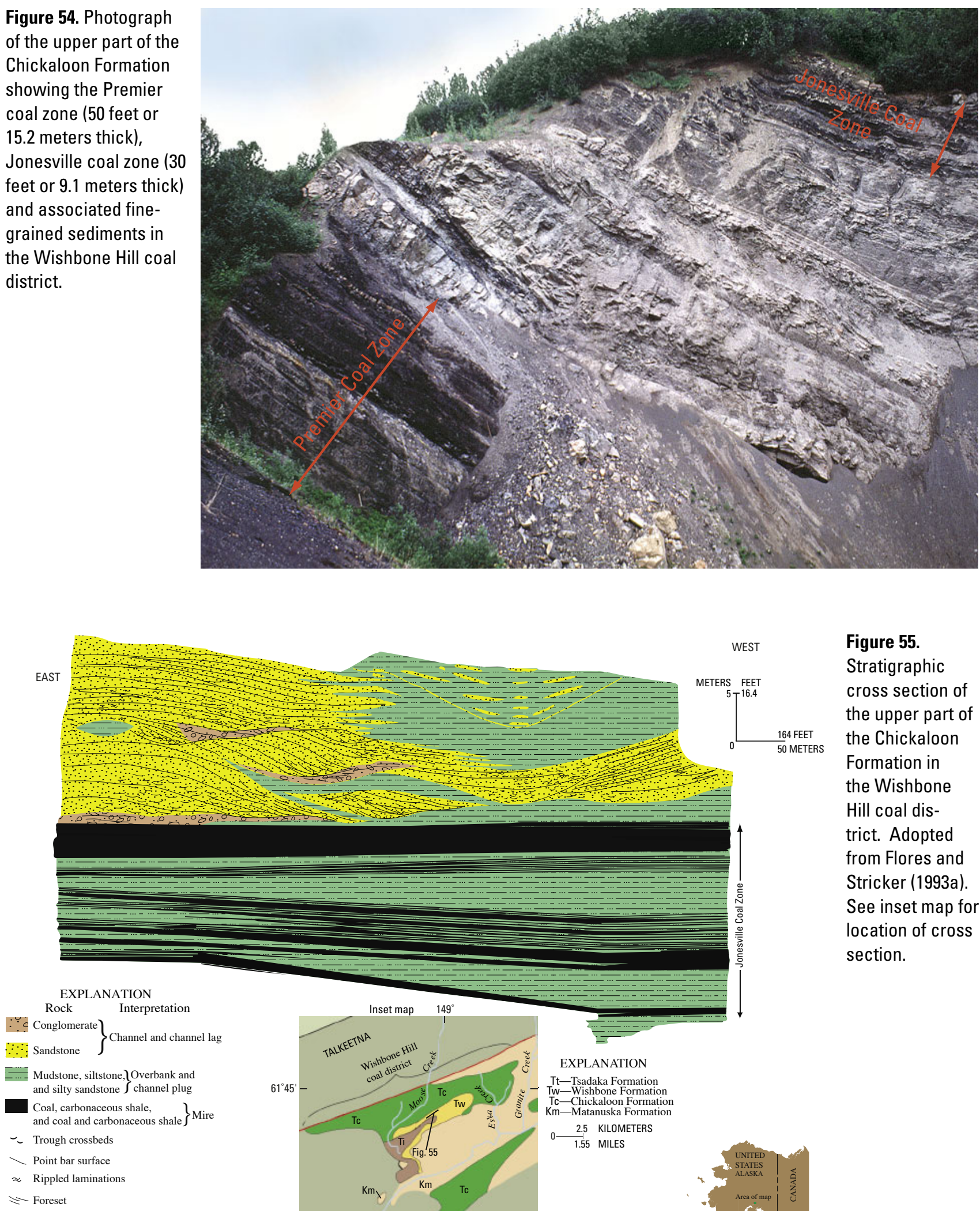

WEST

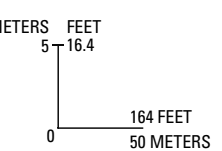

Figure 55.

Stratigraphic cross section of the upper part of the Chickaloon Formation in the Wishbone Hill coal district. Adopted from Flores and Stricker (1993a). See inset map for location of cross section. 


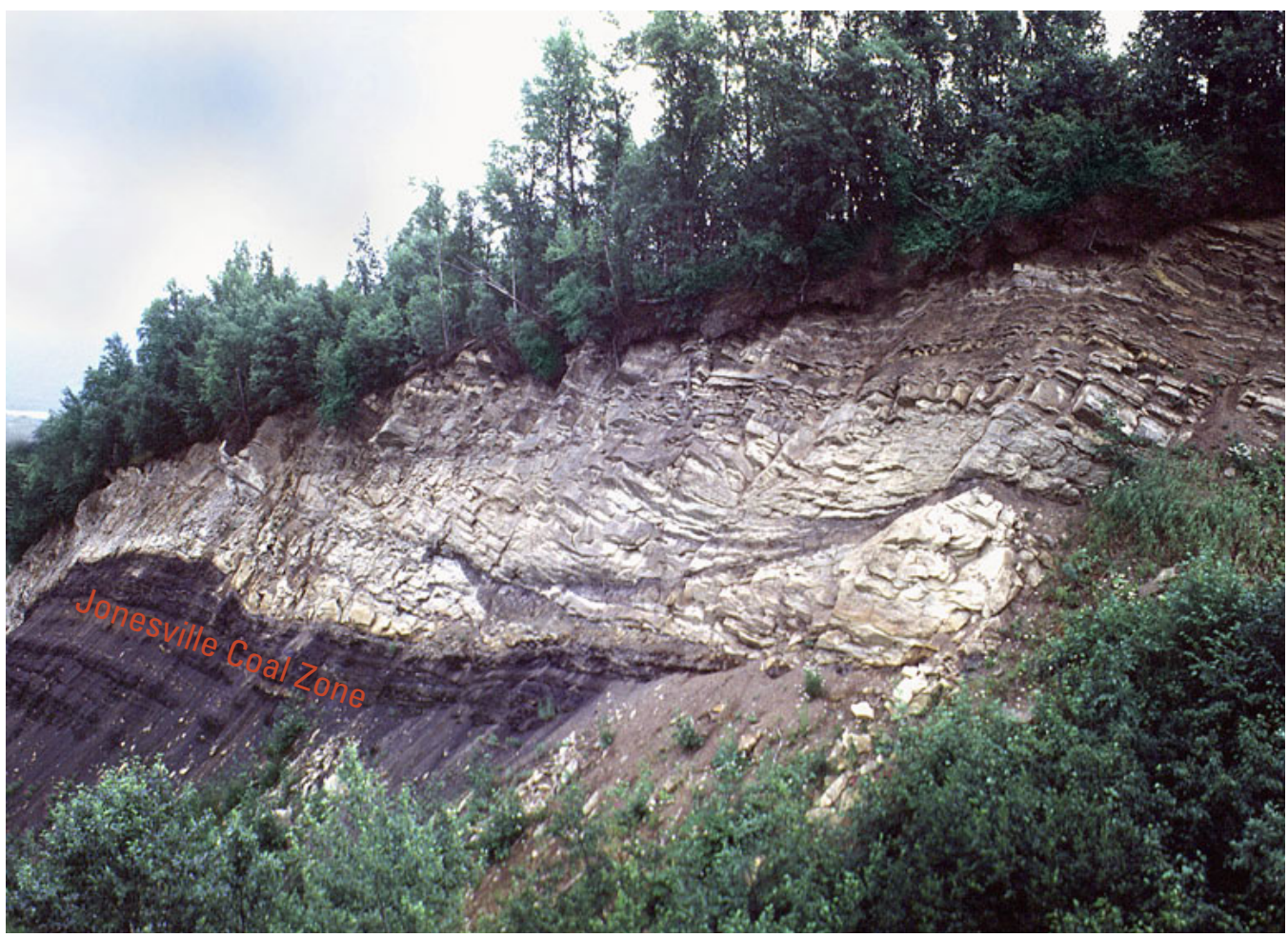

Figure 56. Photograph of the upper part of the Chickaloon Formation showing the Jonesville coal zone overlain by fluvial-channel sandstones ( $>50$ feet or $>15.2$ meters thick) of the Wishbone Formation in the Wishbone Hill coal district.

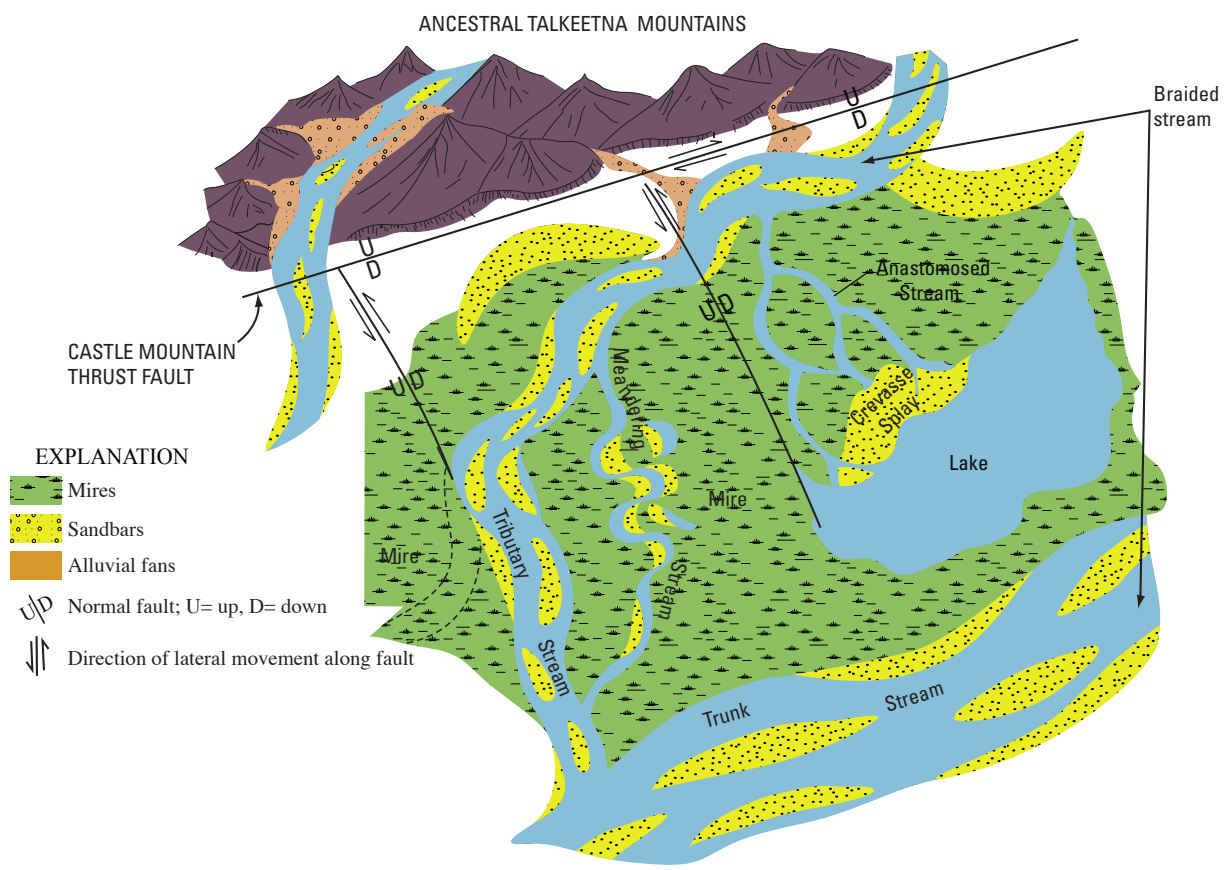

Figure 57. Paleogeographic map showing depositional environments of the Chickaloon Formation in the Matanuska coalfield. Modified from Flores and Stricker (1993a). 


\section{Hemlock Conglomerate}

The Hemlock Conglomerate is unconformable, gradational, and interfingering with the West Foreland Formation (fig. 42). It consists mainly of pebble to boulder conglomerates containing quartz, chert, metamorphic, volcanic, and plutonic rock fragments. Minor conglomeratic sandstones are interbedded, which are arkosic in composition with sparse heavy minerals, predominantly epidote and garnet (Calderwood and Fackler, 1972; Magoon and Egbert, 1986). However, the formation contains a few thin coal beds and many siltstone beds and is the main producing horizon for oil in the offshore Cook Inlet (Magoon and Anders, 1990). Detrital rocks are interpreted as deltaic and lacustrine deposits, and apparently the sediments were derived from the north. Most coals formed in interdistributary low-lying mires. Together with the Bell Island Sandstone and the Tsadaka Formation, temporal equivalents at the east end of the Cook Inlet Basin, the Hemlock Conglomerate forms a variable sheet deposit 655 $\mathrm{ft}(200 \mathrm{~m})$ thick, with a maximum thickness of about $2,772 \mathrm{ft}$ $(845 \mathrm{~m})$. The formation is Oligocene in age (Wolfe and Tanai, 1980; Magoon and Egbert, 1986).

In the Cape Douglas-Katmai National Park area west of the Shelikof Strait (fig. 40) and southeast of the Cook Inlet, Houston (1994) described the 2,772-ft-thick (845 m) Hemlock Conglomerate as consisting of conglomerates and sandstones

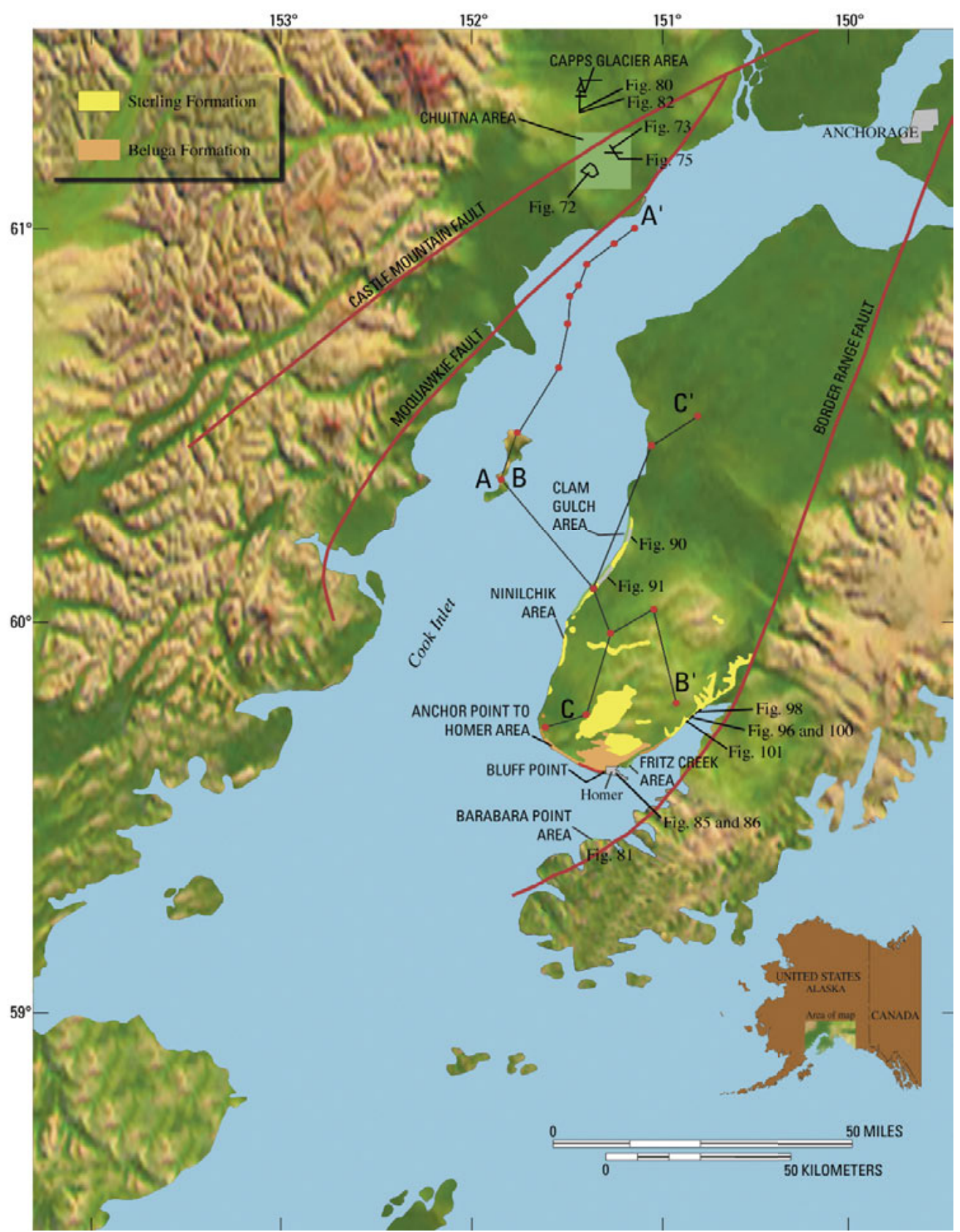

Figure 58. Map showing lines of stratigraphic cross sections (see figs. 59-61) of the Kenai Group in the offshore and onshore Cook Inlet Basin. Map also shows areas of cross sections (see figs. 72-73, 75, 85-86, 90-91) of the Kenai Group in the Chuitna area, Capps Glacier area, along the west coast of Kenai Peninsula, and along the north coast of Kachemak Bay. 


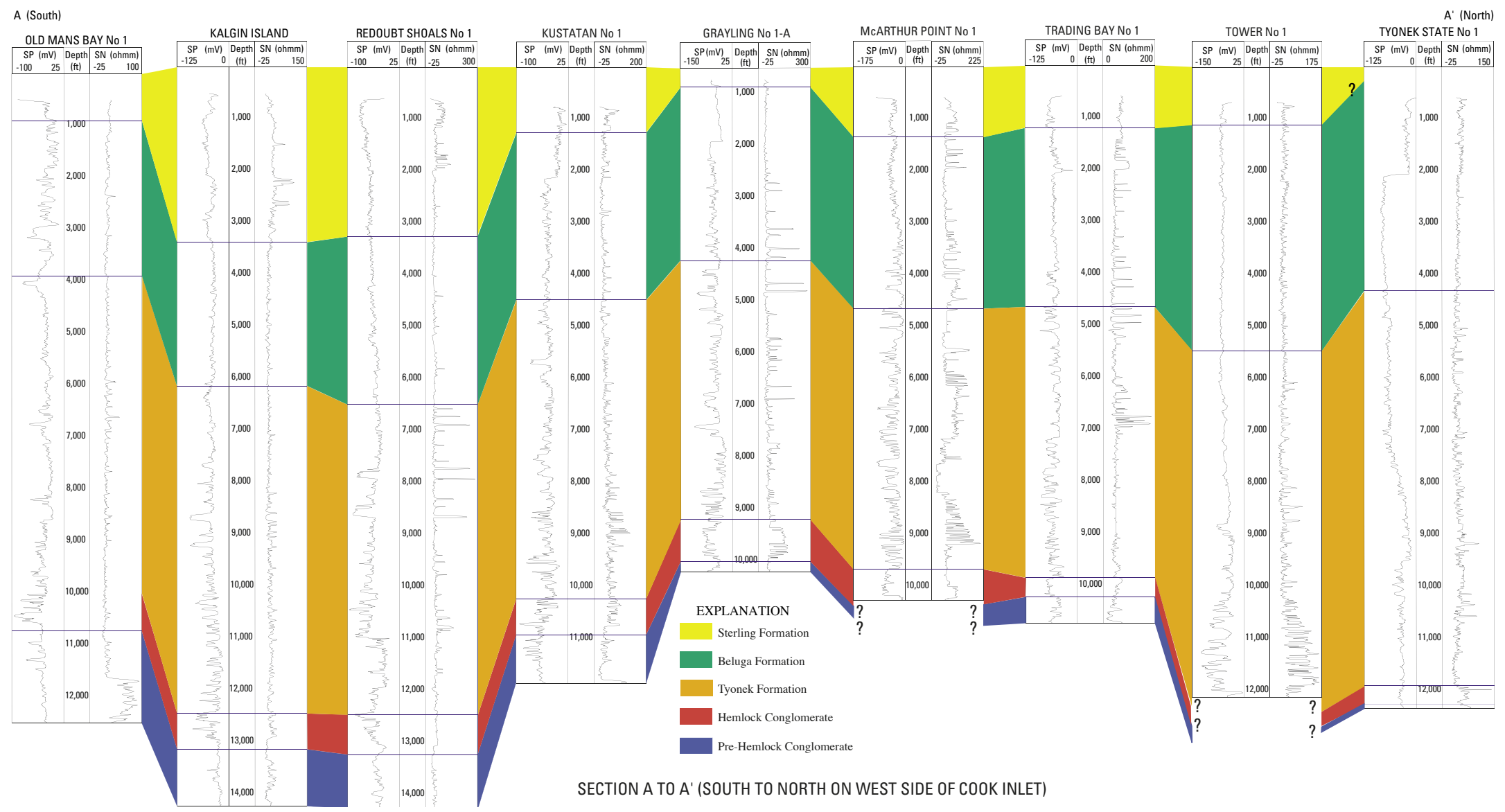

Figure 59. Offshore north-south cross section (A-A') of the Kenai Group along the axis of the Cook Inlet Basin. Modified from Alaska Geological Society (1969a). See figure 58 for location of cross section. 


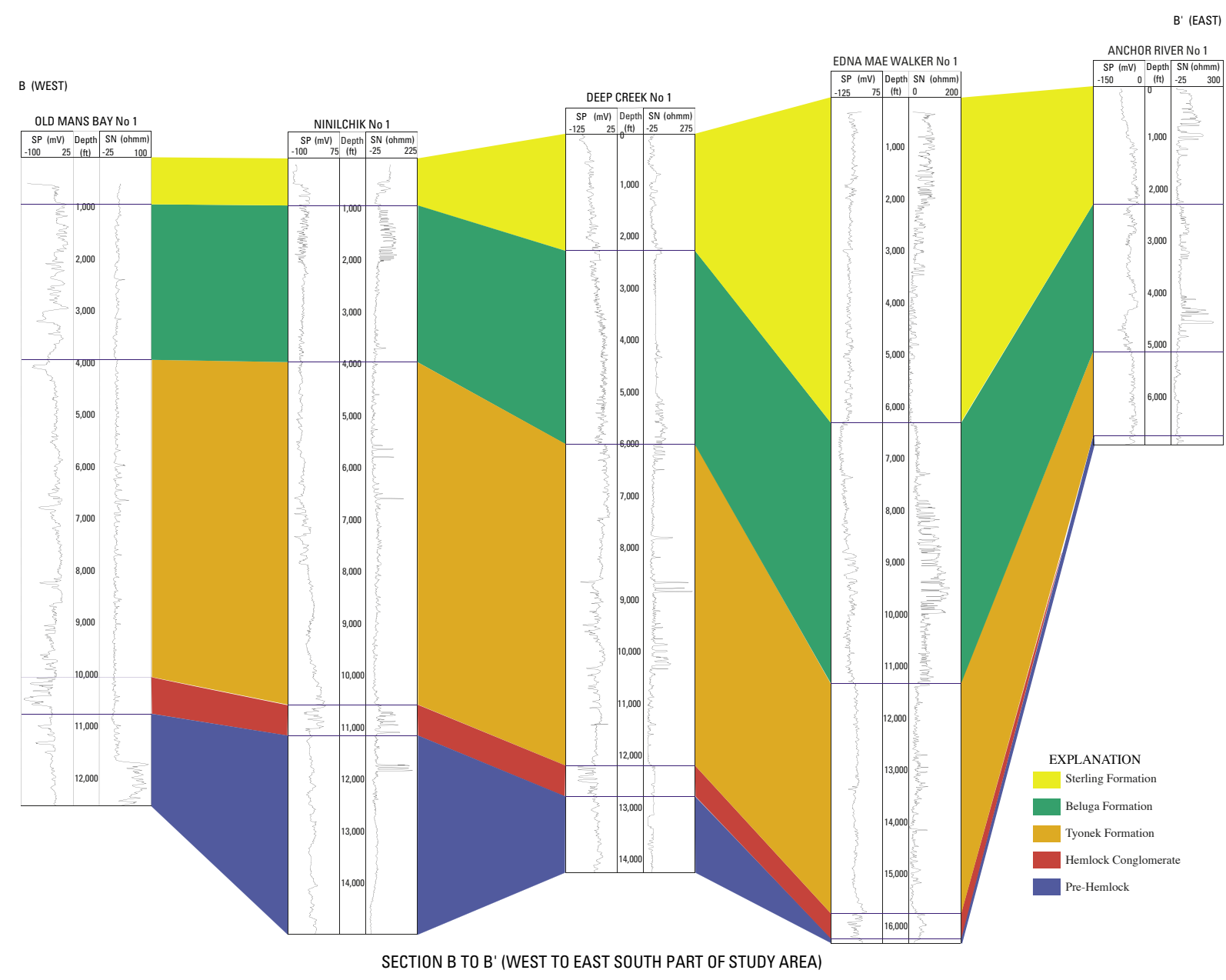

Figure 60. Offshore (west) to onshore (east) cross section (B-B') of the Kenai Group across the Cook Inlet Basin. Modified from Alaska Geological Society (1969b). See figure 58 for location of cross section.

deposited in meandering streams (figs. 62 and 63). Minor siltstones and mudstones were interpreted to be deposited in overbank and flood-plain environments (figs. 64 and 65). Sparse coal and carbonaceous shale beds, which vary from 2 inches to $2.5 \mathrm{ft}$ ( $5 \mathrm{~cm}$ to $0.75 \mathrm{~m}$ ) thick, were interpreted to have accumulated in mires developed on abandoned flood plains and meander belts. These streams derived sediments from the Alaska-Aleutian volcanic arc terrane.

Hite (1976) interpreted the sandstones of the Hemlock Conglomerate distributed along the central part of the Cook Inlet Basin (figs. 59 and 60) as being deposited in a marineinfluenced environment. Based on size analysis and vertical variability mapping, 18 percent of the analyzed samples showed evidence of tidal transport by bidirectional currents. Twenty-five percent of the analyzed samples indicate transport by turbidity or density suspension currents. Hite (1976) interpreted the coal beds to have accumulated in coastal mires and mapped them as two bands (fig. 66) parallel to the basin margins. Also, Hite (1976) suggested that the paleogeographic setting of the basin during deposition of the Hemlock Conglomerate was very similar to the modern Cook Inlet, which is composed of coastal plains influenced by tidal estuaries, flats, and marshes. Although the present report agrees with this scenario, the elongate shape and coastal-parallel (northeastsouthwest orientation) nature of the Hemlock sandstones in the central part of the Cook Inlet Basin, which were interpreted by Hite (1976) as tidal channel and turbidity deposits, are here reinterpreted as tidal sand-flat deposits. These tidal sand flats were probably derived by reworking of deltaic sediments of the streams that deposited the Hemlock Formation in the Cape Douglas-Katmai National Park area southeast of the basin.

\section{Tyonek Formation}

The Tyonek Formation (Wolfe and Tanai, 1980) consists of a sequence of sandstones, siltstones, mudstones, carbonaceous shales, and coal beds as much as 7,640 $\mathrm{ft}(2,330 \mathrm{~m})$ thick (fig. 67; Calderwood and Fackler, 1972). Sandstones, the most common rock type, are basally erosional, crossbedded, thick, and vertically stacked (fig. 68). Individual coal beds are as much as $33 \mathrm{ft}(10 \mathrm{~m})$ thick. A sandstone:mudstone ratio map of the formation by Hartman and others (1971) shows more than 50 percent sandstone in an area along the west side 
NORTH FORK No 41-35 SP (mV) Depth SN (ohmm)

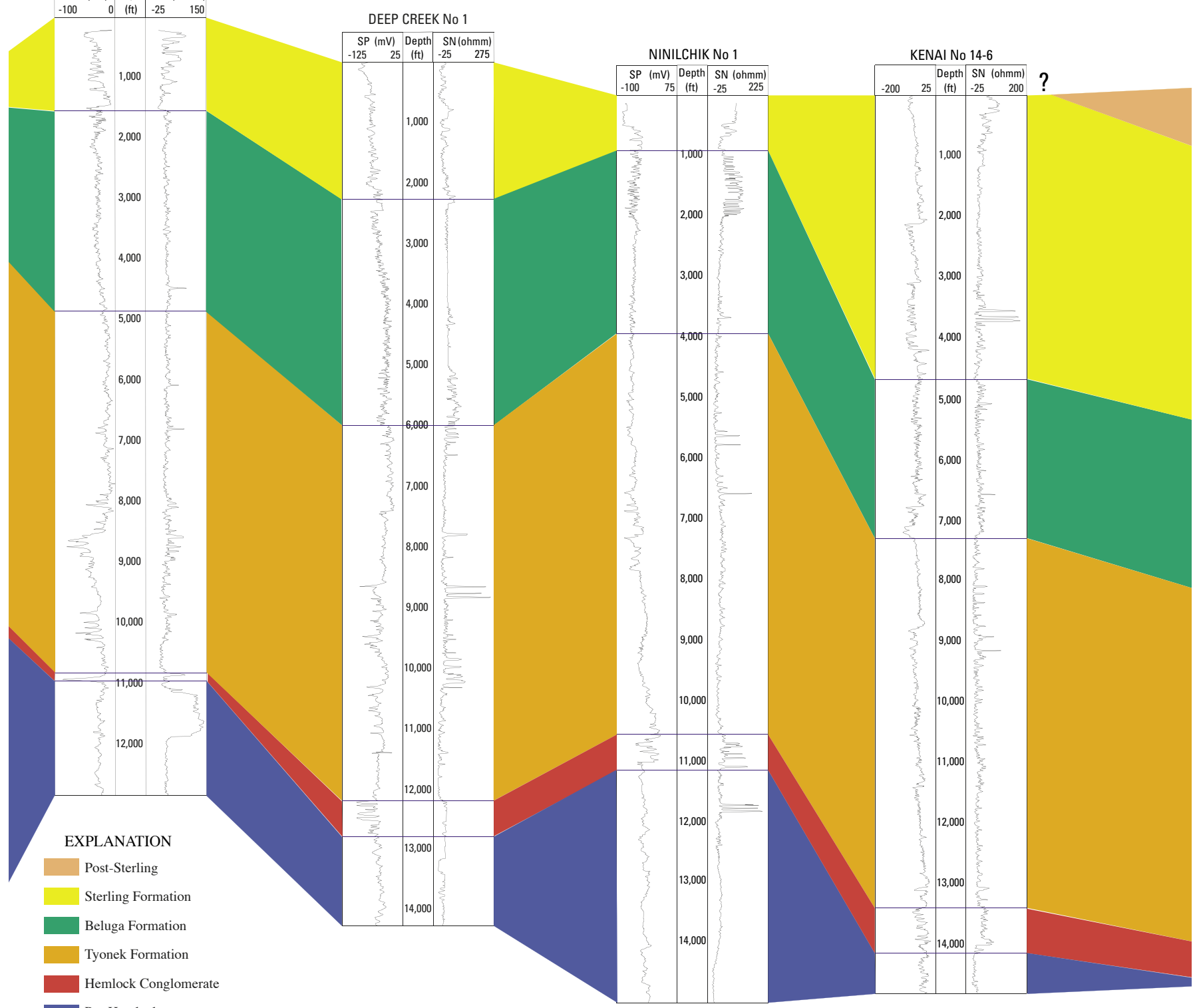

Pre-Hemlock
Figure 61. Onshore northsouth cross section (C-C') of the Kenai Group along the western part of the Kenai Peninsula or eastern margin of the Cook Inlet

Basin. Modified from

Alaska Geological Society

(1969c). See figure 58 for location of cross section. 


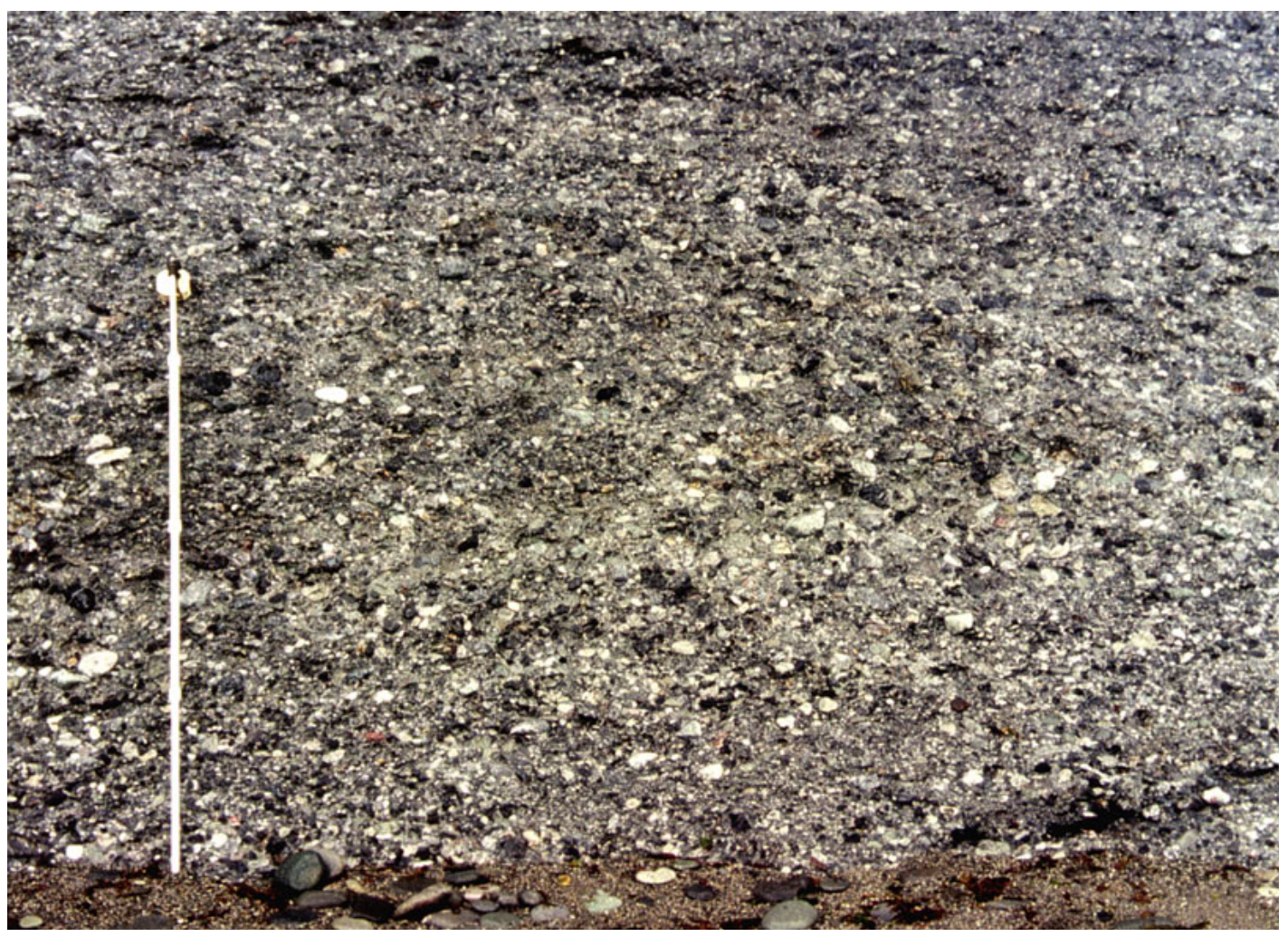

Figure 62. Photograph of conglomerates in the Hemlock Conglomerate in the Katmai National Park. Jacob's Staff is 5 feet (1.5 meters) long for scale. Photograph courtesy of Frank Ethridge.

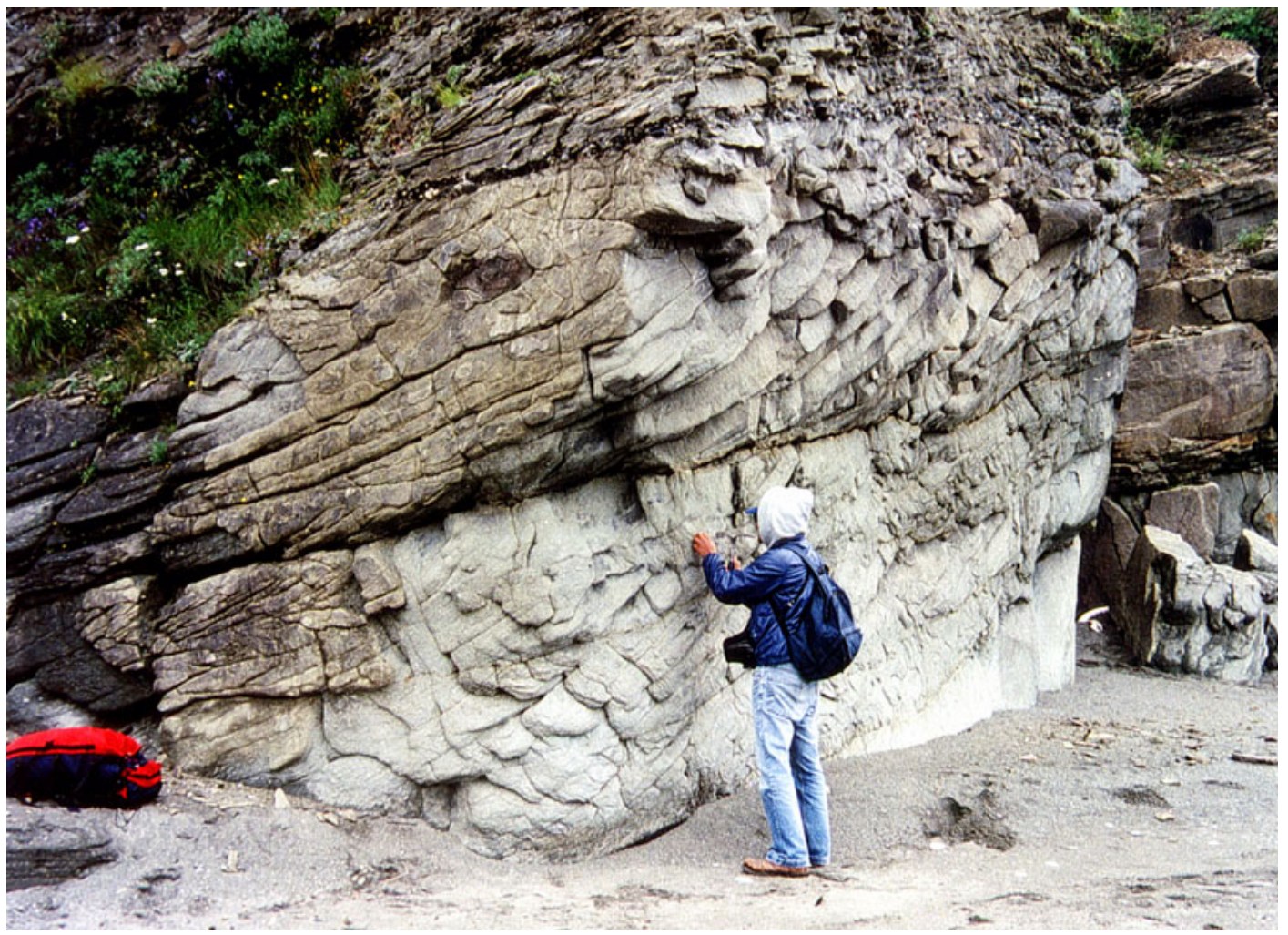

Figure 63. Photograph of sandstones in the Hemlock Conglomerate in the Katmai National Park. Man is 5.5 feet (1.7 meters) tall for scale. Photograph courtesy of Frank Ethridge. 


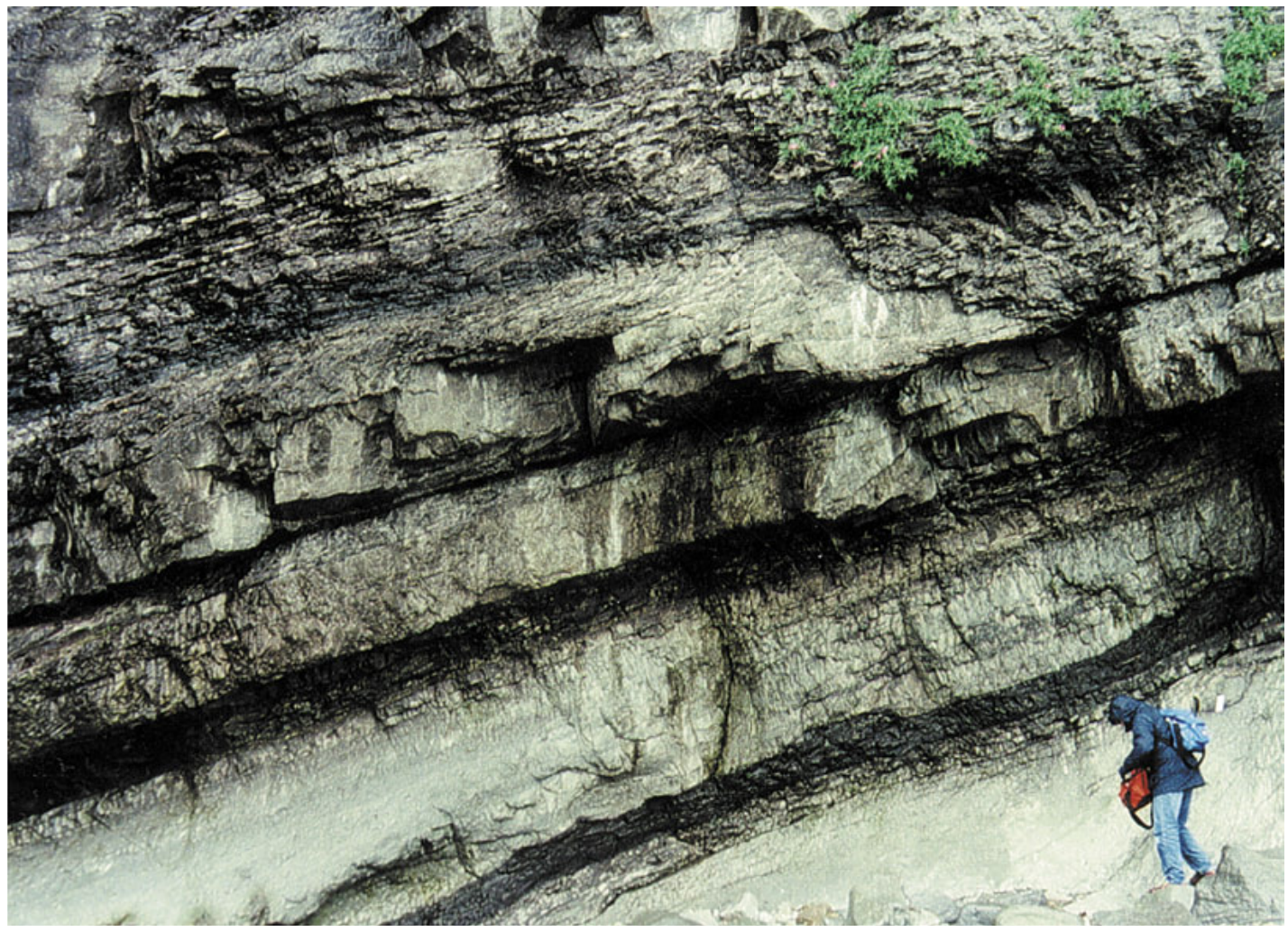

Figure 64. Photograph of thin coal and carbonaceous shale beds in the Hemlock Conglomerate in the Katmai National Park. Man is 6 feet (1.8 meters) tall for scale. Photograph courtesy of Frank Ethridge.

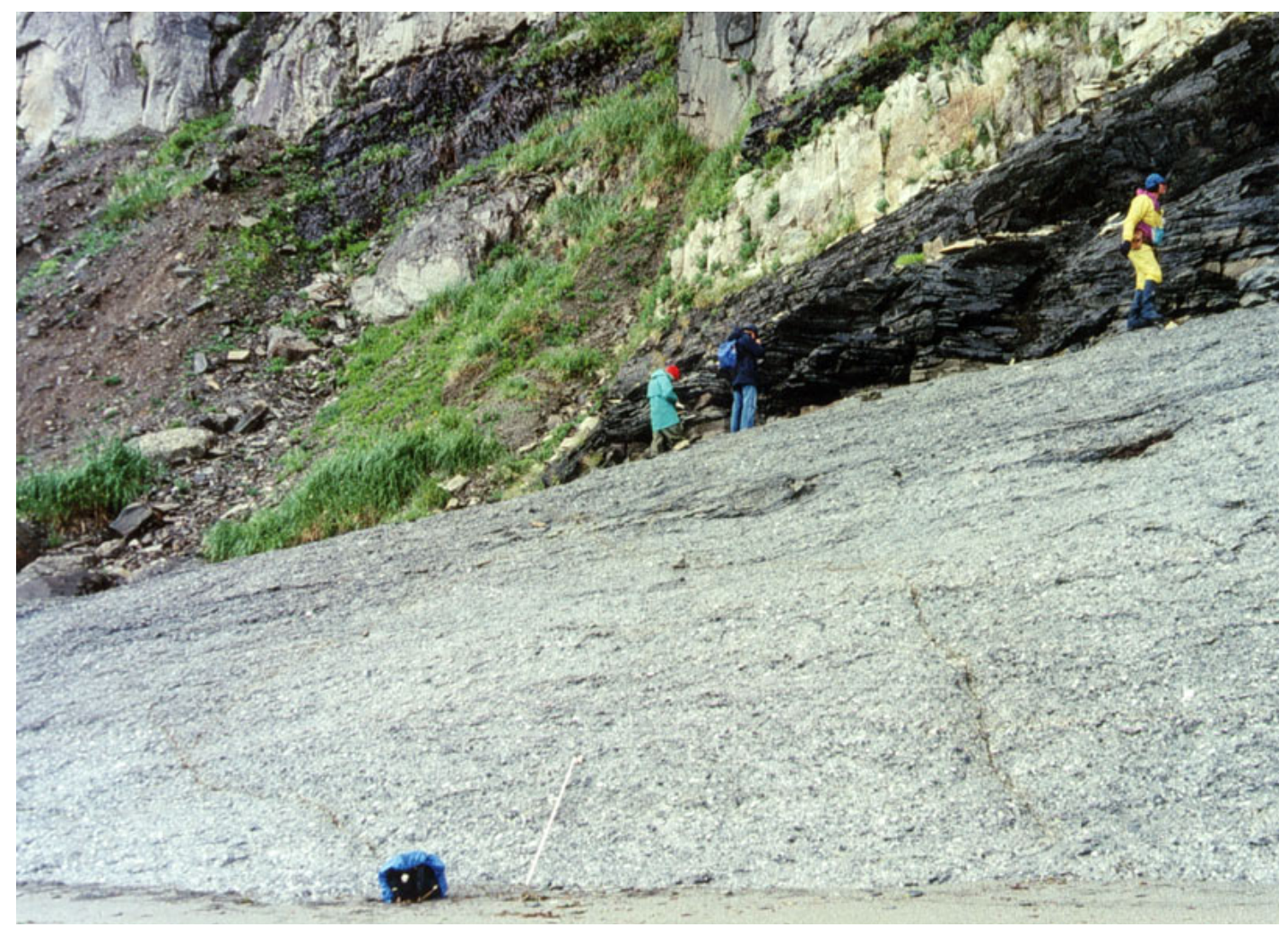

Figure 65. Photograph of braided stream deposits (conglomeratic lower part) in the Hemlock Conglomerate. The upper part contains fluvial-channel sandstones and carbonaceous siltstones. Jacob's staff in the lower part of the photograph is 5 feet (1.5 meters) long for scale. Photograph courtesy of Frank Ethridge. 


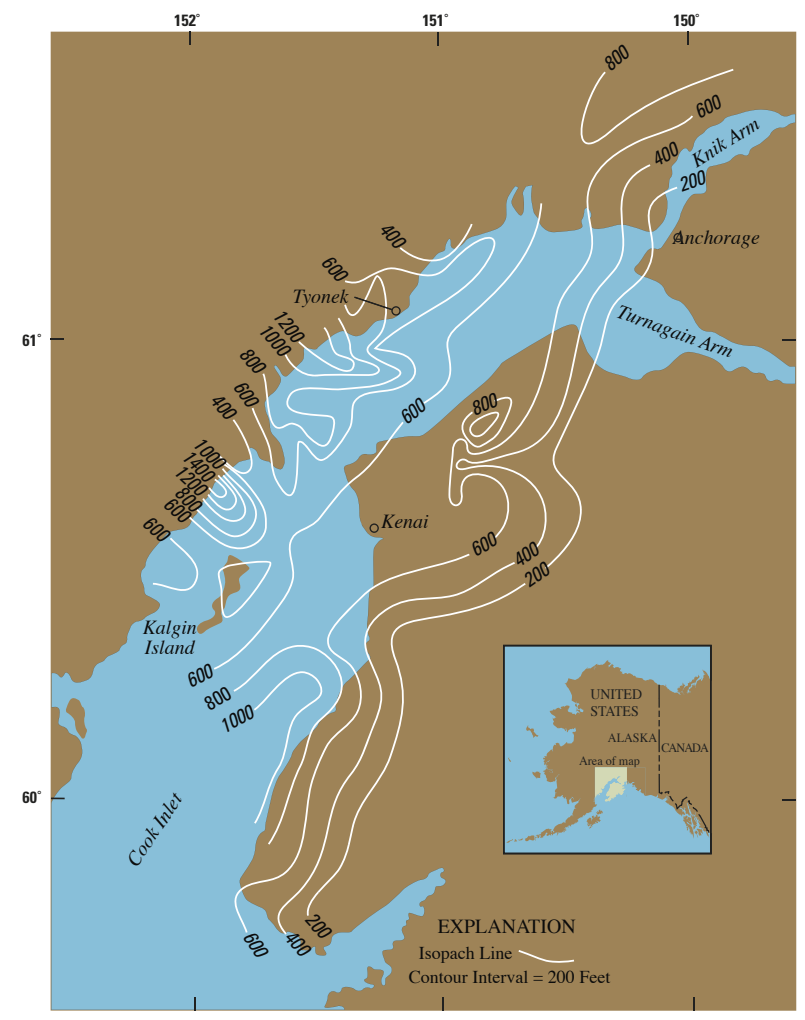

Figure 66. Net coal thickness isopach map of the Tyonek Formation in the Cook Inlet Basin. Modified from Hite (1976) and Wahrhaftig and others (1994).

of the Cook Inlet Basin and in the extreme northeastern part of the basin. The sites with higher sandstone content were interpreted as loci of sediment input. An extensive mudstone band containing as little as 10 percent sandstone extends south-southwestward along the western part of the Kenai Peninsula. Sandstone content increases southeastward of this band of maximum mudstone content. This site of extensive belt of mud represents the distal point of sandstone input.

Hite (1976) presented an isolith sand map (net sandstone thickness isopach map) of the Tyonek in the Cook Inlet Basin (see fig. 69) that shows the high concentration of sandstone along the western part of the basin and decreasing toward the eastern part. In addition, on the west side, the contour lines define a lobate concentration of sandstone, which flares as elongate bodies to the northeast and southeast of the basin. We interpret these sandstone concentrations as alluvial-fan delta and tidal-flat deposits (fig. 70).

The alluvial-fan delta and tidal-flat lithofacies of the Tyonek Formation were studied by Flores and others (1994) and Flores, Stricker, and Stiles (1997) whose descriptions of the vertical and lateral variations of these facies in the Chuitna River drainage basin, about 10 miles $(16 \mathrm{~km})$ northeast of Tyonek, are depicted graphically in figures 71, 72, and 73. The tidal sand flat and intertidal lithofacies as described by Flores and others (1999) $2.6 \mathrm{mi}(4.2 \mathrm{~km})$ northwest of Wasilla are shown in figure 74 . Sediments of the tidal sand flats may have been sourced from the alluvial-fan delta sediments and reworked by tidal currents. Streams from adjacent areas to the north and east of the Cook Inlet Basin may also have contributed minor amounts of sediment.

The net total thickness of coal beds penetrated in wells in the Tyonek Formation increases toward the northwestern part of Cook Inlet Basin (see fig. 66; Hite, 1976; Wahrhaftig and others, 1994). The beds are concentrated along the northwest margin of the basin, from Kalgin Island northeastward along the west shore of the inlet to the Susitna River. In that area, the coal isopach map displays lobe shape with fingerlike extensions oriented to the east and southeast (see fig. 66). Lobe-shaped coal concentrations, which also correspond to the sites of lobate concentrations of sandstones, are interpreted as having been deposited in mires associated with alluvial-fan deltas. At those sites, abandoned alluvial-ridge braid belts of the fan deltas served as raised platforms where mires devel-

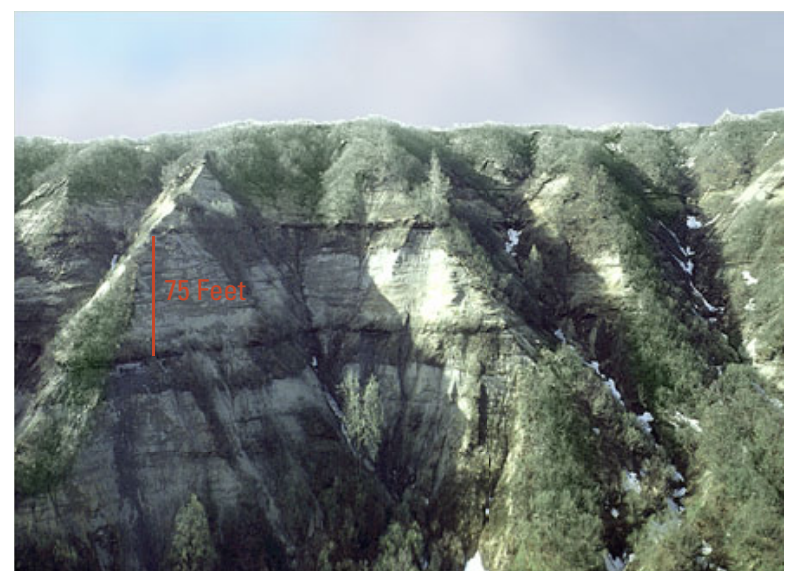

Figure 67. Photograph of coal beds and interbedded fluvial-channel sandstones and mudstones in the Tyonek Formation in the Chuitna River drainage basin. The sandstone in the upper part of the outcrop is 75 feet $(22.8$ meters) thick for scale.

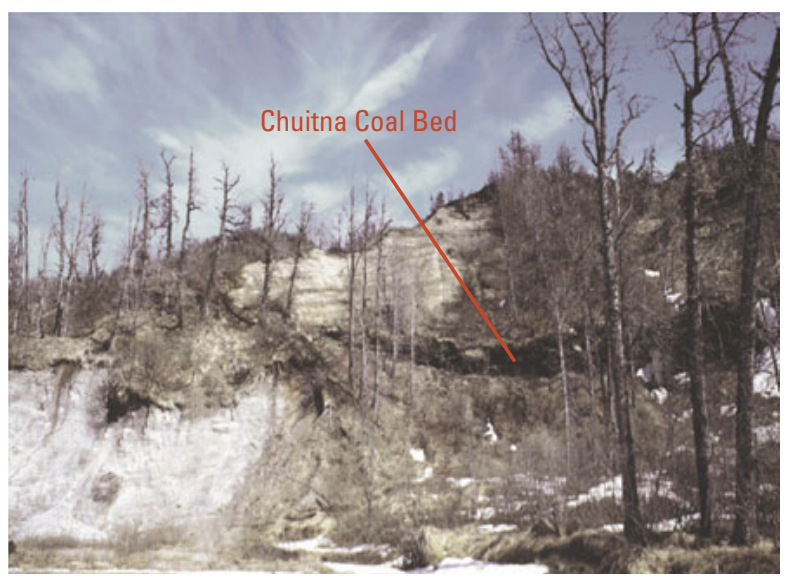

Figure 68. Photograph of fluvial-channel sandstones and Chuitna coal bed in the Tyonek Formation in the Chuitna River drainage basin. The sandstone in the lower part of the outcrop is 50 feet (15.2 meters) thick for scale. 


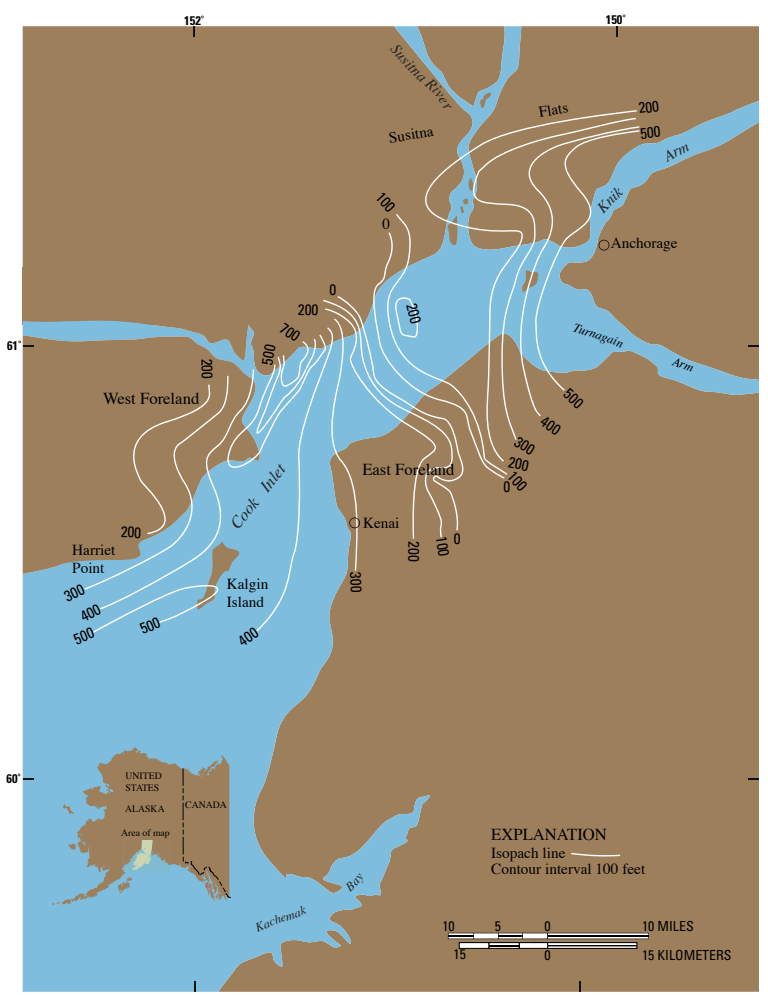

Figure 69. Net sandstone thickness isopach map of the Tyonek Formation in the Cook Inlet Basin. Modified from Hite (1976).

oped as much as $28 \mathrm{ft}(8.5 \mathrm{~m})$ of minable coal (see figs. 72 and 73 ) as described at the Diamond Chuitna coal-mine lease area by Flores and others (1994) and Flores, Stricker, and Stiles (1997). However, the coal beds are associated with intertidal sediments indicating development in supratidal mires (figs. 75,76 , and 77). The fingerlike pattern of the net coal thickness isopach map (see fig. 66) indicates tidal influence much like the mires along the coast in west-central Sumatra, Indonesia (Flores and Moore, in press).

The total coal isopach map (fig. 66) shows thinning to the northeast, southeast, and southwest toward the zone of minimum sandstone content (Hartman and others, 1971; Hite, 1976). The southwest-northeast orientation of the net coal thickness isopach, a trend that is perpendicular to the southeast-oriented deltaic wedges, indicates accumulation of coal in low-lying tidal sand flat and supratidal mires. Tidal influence in the Tyonek Formation in the Barabara Point, southwest of Kachemak Bay (see fig. 40) in the eastern Cook Inlet was described by Stricker and Flores (1996). However, the tidal deposits overlie a sequence of conglomerate, sandstone, siltstone, and mudstone, with coals a few inches to $2 \mathrm{ft}$ (few centimeters to $0.6 \mathrm{~m}$ ) thick (fig. 77). Mudstones and siltstones are the most abundant lithologies, which are interpreted to be derived from the Chugach metamorphic rock complex. Stricker and Flores (1996) and Myers and others (1998) interpreted this sequence as an alluvial fan drained mainly by anastomosed streams.

The thick Capps Glacier coal bed (figs. 78, 79, and 80) and coal beds along the Beluga and Chuitna Rivers (Barnes, 1966; Adkison and others, 1975; Myers and others, 1998) are in the Tyonek Formation (Magoon and others, 1976). Within a single coalfield, correlation of the coal beds from well to well has proved difficult for distances of more than a mile (few kilometers), which indicates considerable lenticularity of the coal seams and the intervening sedimentary rocks. The rapid changes in the lateral and vertical stratigraphy of the coal beds and intervening rocks are shown in figures 81 and 82 . In both cross sections, the Capps Glacier coal bed is traceable for a mile or two; however, the coal bed splits and merges laterally as influenced by the thinning, pinching out, and thickening of the intervening fluvial channel sandstones. The pattern of the
Figure 70. Paleogeographic map (block diagram) showing depositional environments of the Tyonek Formation in the Cook Inlet Basin. Modified from Hite (1976).

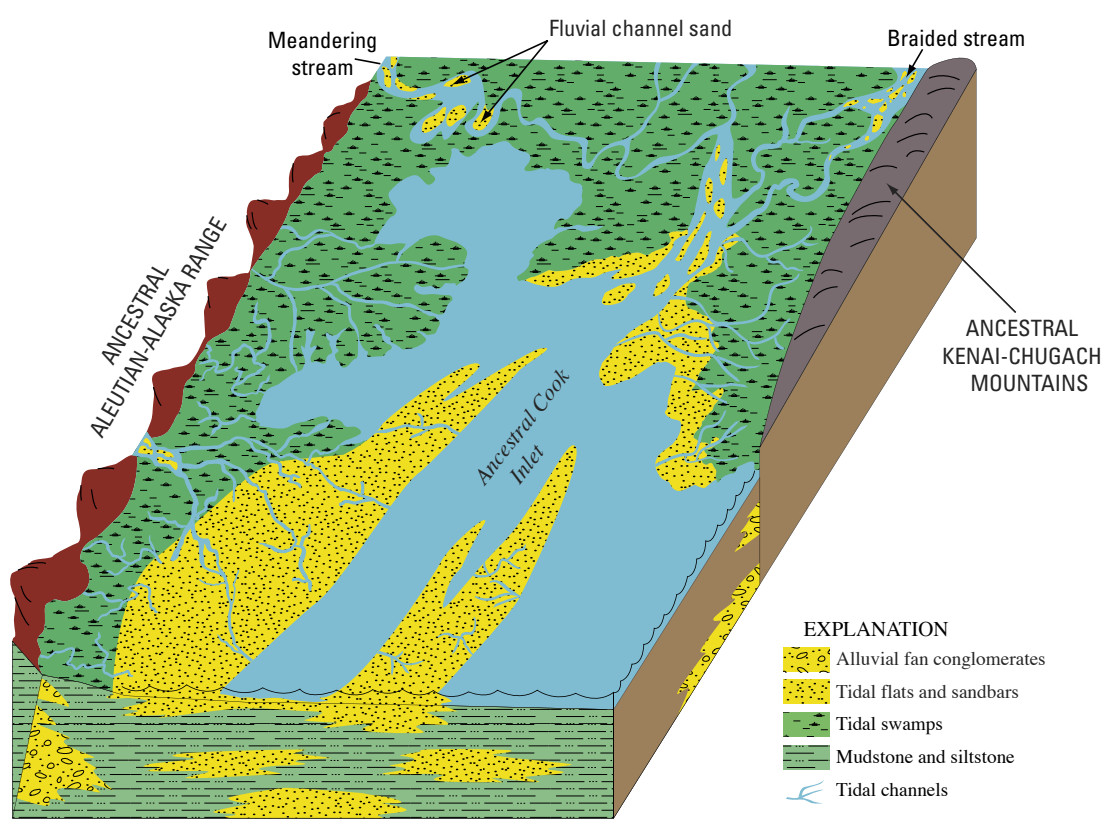


coal bed wrapping around the sandstones is enhanced by differential compaction. That is, the sandstones are less compactible than adjacent mudstones. In outcrop, however, individual coal beds have been traced for as much as $6.2 \mathrm{mi}(10 \mathrm{~km})$

(Barnes, 1966; Ramsey, 1981).

Nearly flat-lying outliers of the Tyonek Formation along the southeast shore of Kachemak Bay near Seldovia Bay and at Port Graham (see fig. 40) rest unconformably on metamorphic rocks of Triassic and Jurassic age and appear in part to fill steep-sided valleys and in part to be downfaulted (Stone, 1906; Martin and others, 1915; Magoon and others, 1976). The occurrence on the northeast side of the entrance to Port Graham was the site of the plant fossils on which Oswald Heer in 1869 (Wahrhaftig and others, 1994) established the "Arctic Miocene" flora of Alaska (see Stone, 1906), and the locality on which the name "Kenai Formation" (now Kenai Group) was established by Dall (1896). Portlock first reported coal there in 1786 (see Stone, 1906, p. 54). Coal (chiefly lignite)

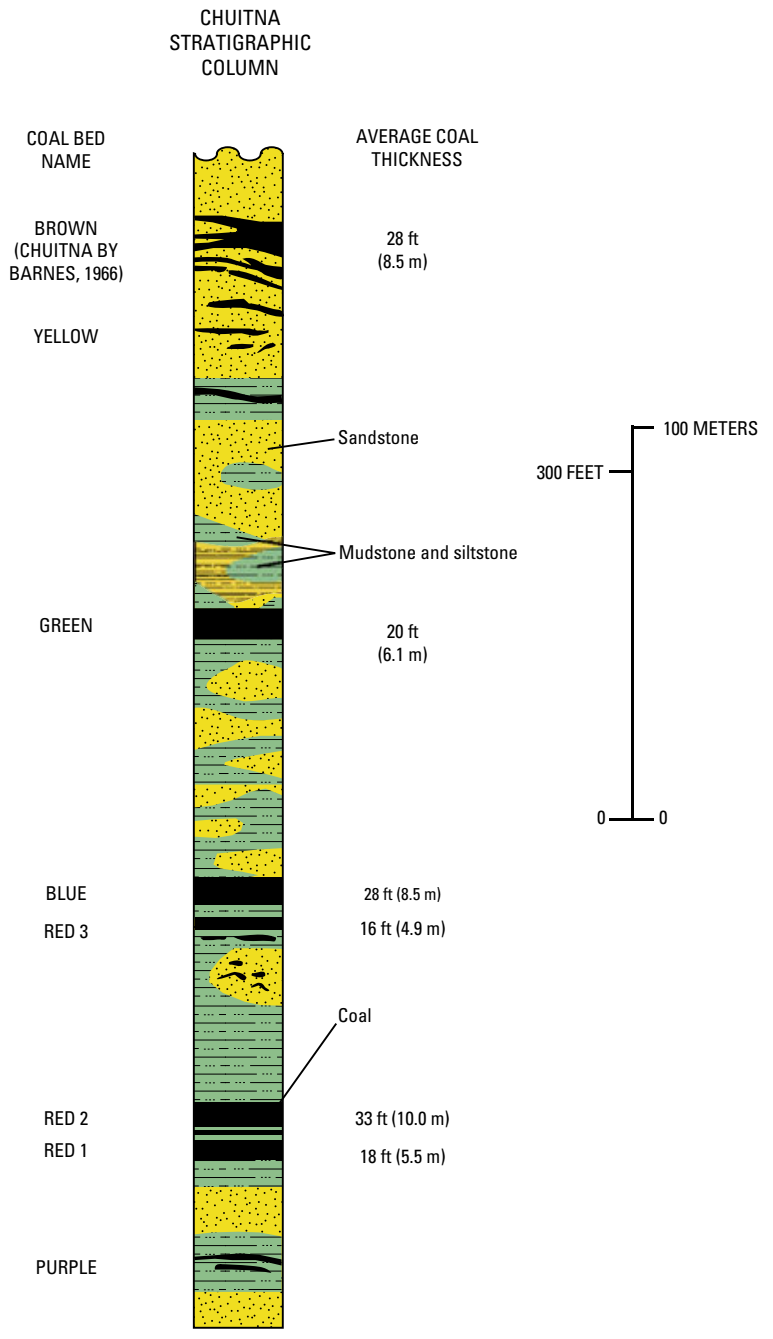

Figure 71. Generalized stratigraphic column of minable coal beds in the Tyonek Formation in the Chuitna River drainage basin and adjoining areas. Modified from Flores and others (1994) and Flores, Stricker, and Bader (1997). was mined at this site by the Russians from 1855 to 1867 , but it could not be produced at a profit, and operations ceased when Alaska was sold to the United States in 1867 (Stone, 1906).

\section{Beluga Formation}

The Beluga Formation (fig. 42) is as much as 4,900 ft $(1,500 \mathrm{~m})$ thick, is composed of interbedded conglomerates, sandstones, siltstones, mudstones, carbonaceous shales, and coal beds (see fig. 44). The sandstones are the most abundant rock type and coal beds are the least common. The sandstones are erosional based, as much as $50 \mathrm{ft}(15 \mathrm{~m})$ thick, crossbedded, and vertically stacked (figs. 83 and 84; Flores and Stricker, 1993b). Stratigraphic variations of the sandstones and coal beds are shown in figures 85 and 86 . These lithic units are drab-gray in color. In the outcrop, the color of the formation is used to distinguish it from the overlying buff to light-brown Sterling Formation (Barnes and Cobb, 1959; Wolfe and others, 1966; Merritt and others, 1987). Abundant heavy minerals (Kirschner and Lyon, 1973) and metamorphic rock fragments in the locally pebbly sandstones led Hayes and others (1976) to interpret the Beluga Formation to be derived mainly from the Kenai and Chugach Mountains. Paleocurrent analysis of crossbeds of the sandstones by Rawlinson (1984) and Kremer and Stadnicky (1985) indicate a westerly transport direction of its sediments. The Beluga Formation is well exposed in beach bluffs along the northwest side of Kachemak Bay and the south-southwest end of the Kenai Peninsula between Homer and Anchor River (Magoon and others, 1976; Merritt and others, 1987). There it contains numerous coal beds with individual beds as thick as $6.6 \mathrm{ft}$ (2 m) (Barnes and Cobb, 1959). The formation was dated as middle and late Miocene (Wolfe and Tanai, 1980).

Environments of deposition of the Beluga Formation are interpreted to be braided and meandering streams and alluvial fans (fig. 87; Hayes and others, 1976; Hite, 1976; Rawlinson, 1984; Merritt, 1986). Recent studies by Flores and Stricker (1992, 1993b) indicate deposition in an alluvial plain drained by alternating braided streams and crevasse splay-anastomosed streams. Through time the braided streams evolved into the crevasse splay-anastomosed streams, which, in turn, evolved into the braided streams. Regional and basin subsidence and autocyclic avulsion processes caused these alternations through time. Flores and Stricker (1993b) suggested that the coal beds accumulated in mires on abandoned braid belts and anastomosed stream belts. However, the coal beds formed in mires on braid-belt deposits were thicker and more extensive than coal formed in mires developed on crevasse-splayanastomosed deposits.

Hayes and others (1976) suggested that the Beluga Formation was deposited by meandering streams along the length of the western part of the Cook Inlet Basin. These stream deposits, which are the chronostratigraphically equivalent of the Lignite Creek Formation (Central Alaska-Nenana coal 


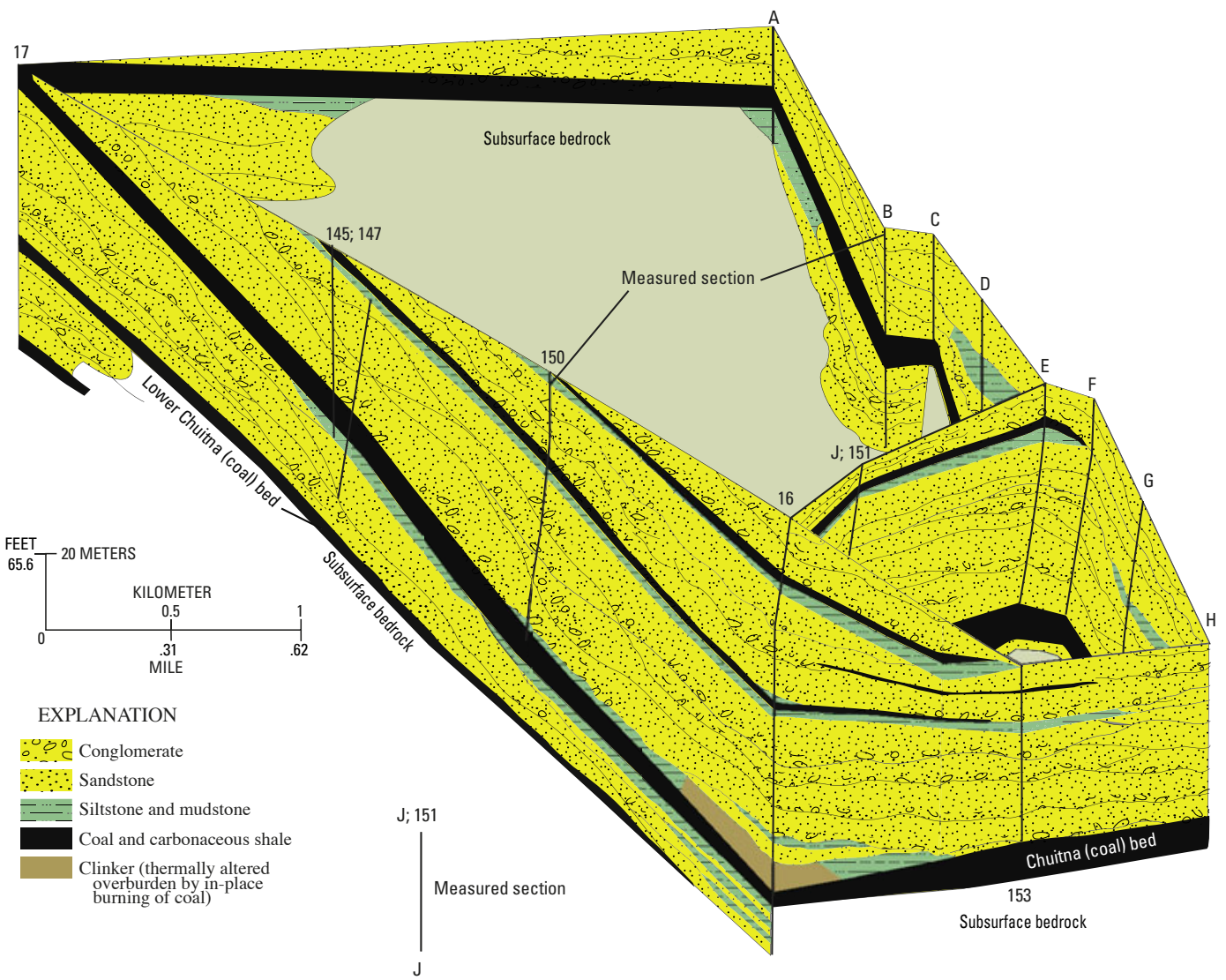

Figure 72. Three-dimensional cross sections (fence diagram) of the Chuitna coal bed and interbedded erosional-based sandstones deposited by braided streams of the Tyonek Formation in the Chuitna River drainage basin. Adopted from Flores and others (1994). See figure 58 for location of the cross section.

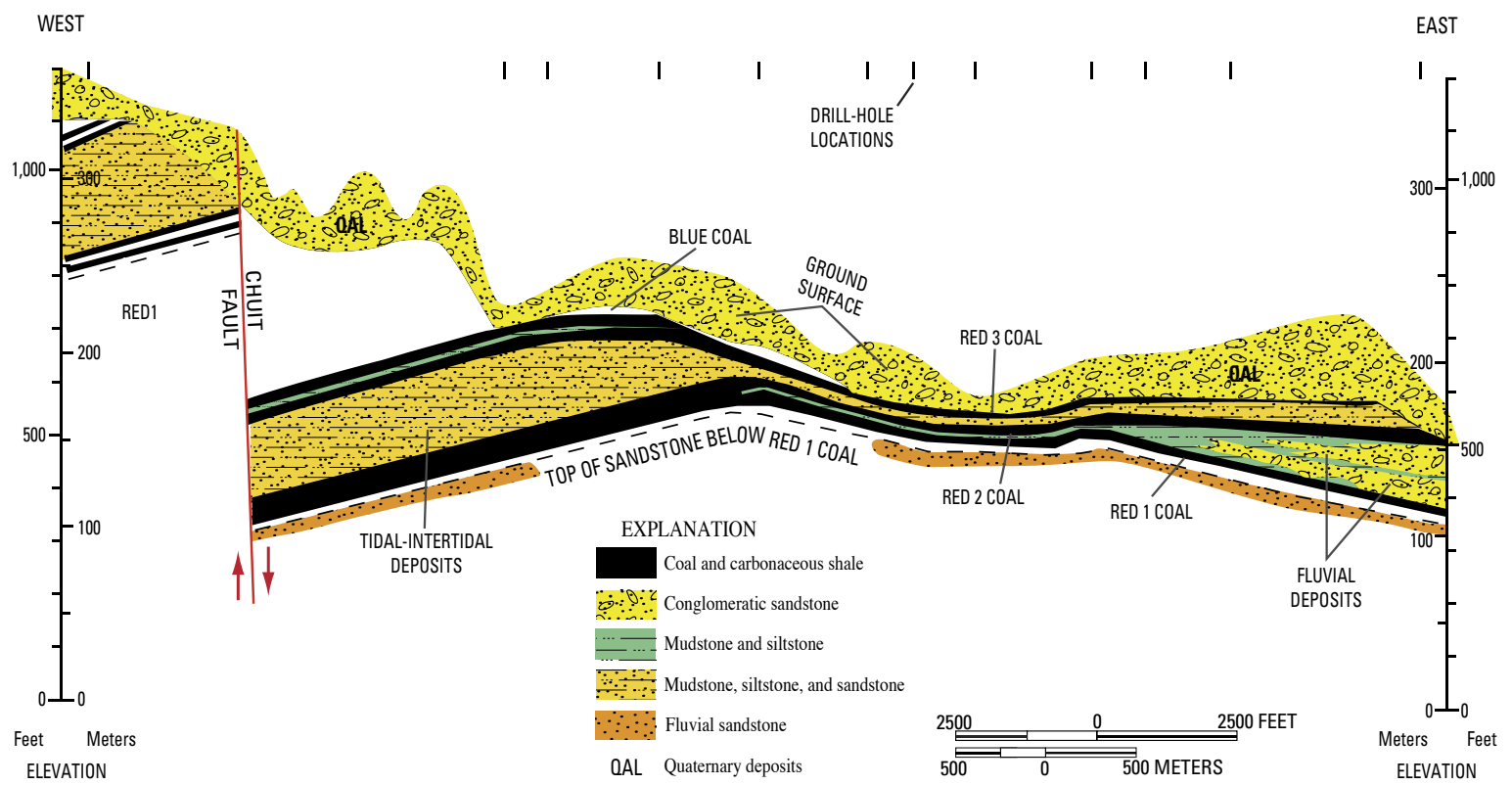

Figure 73. Stratigraphic cross section of the coal beds, fluvial-channel sandstones and intertidal deposits in the Diamond Chuitna lease area east of the Chuitna River drainage basin. See figure 58 for location of the cross section. Adopted by Flores, Stricker, and Stiles (1997). 


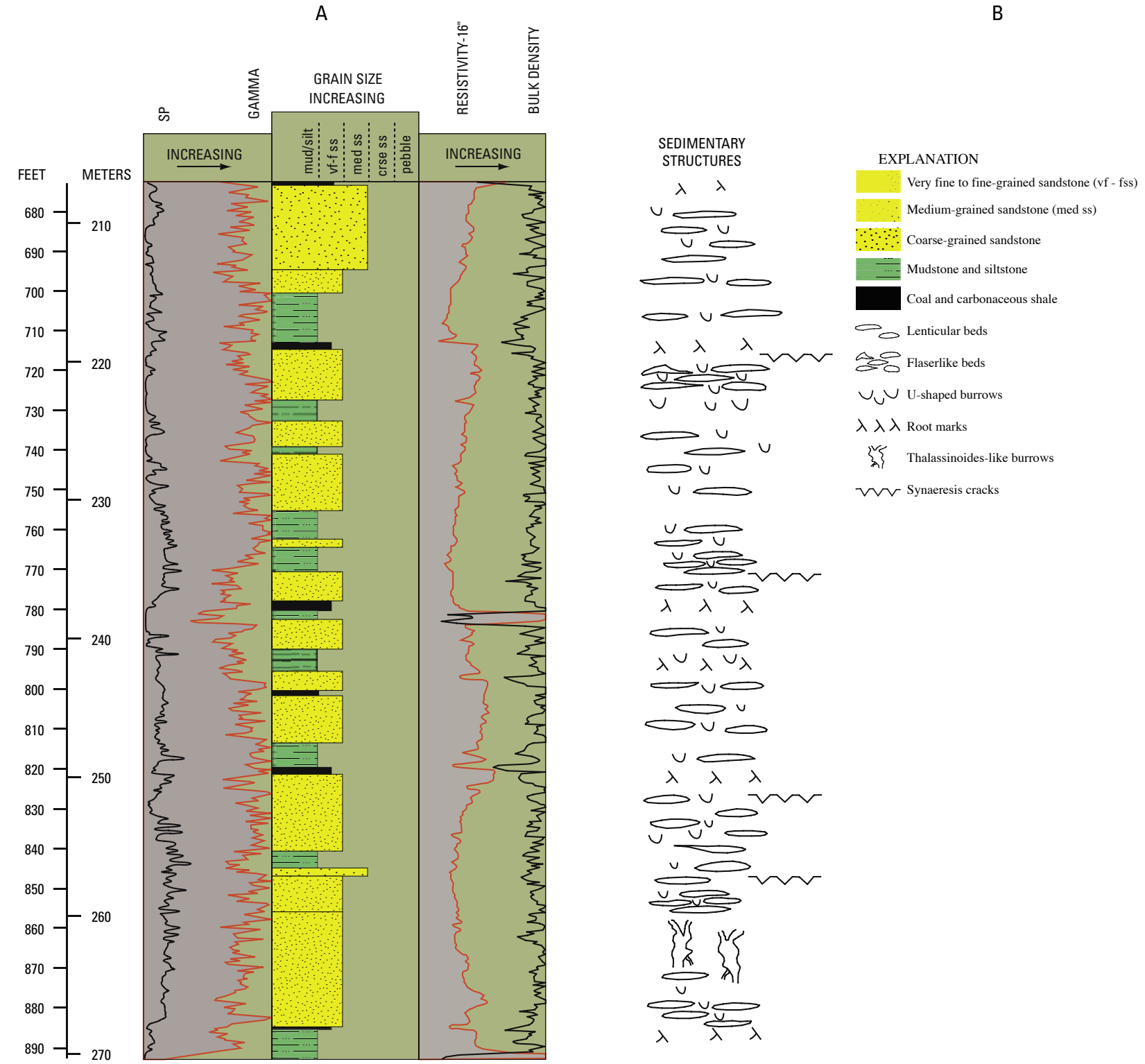

Figure 74. A, Stratigraphic lithofacies sequence in the Tyonek Formation showing tidal sandstone flats facies near Wasilla. Adopted from Flores and others (1999). B, Explanations of sedimentary structures for figures 74A and 77. 


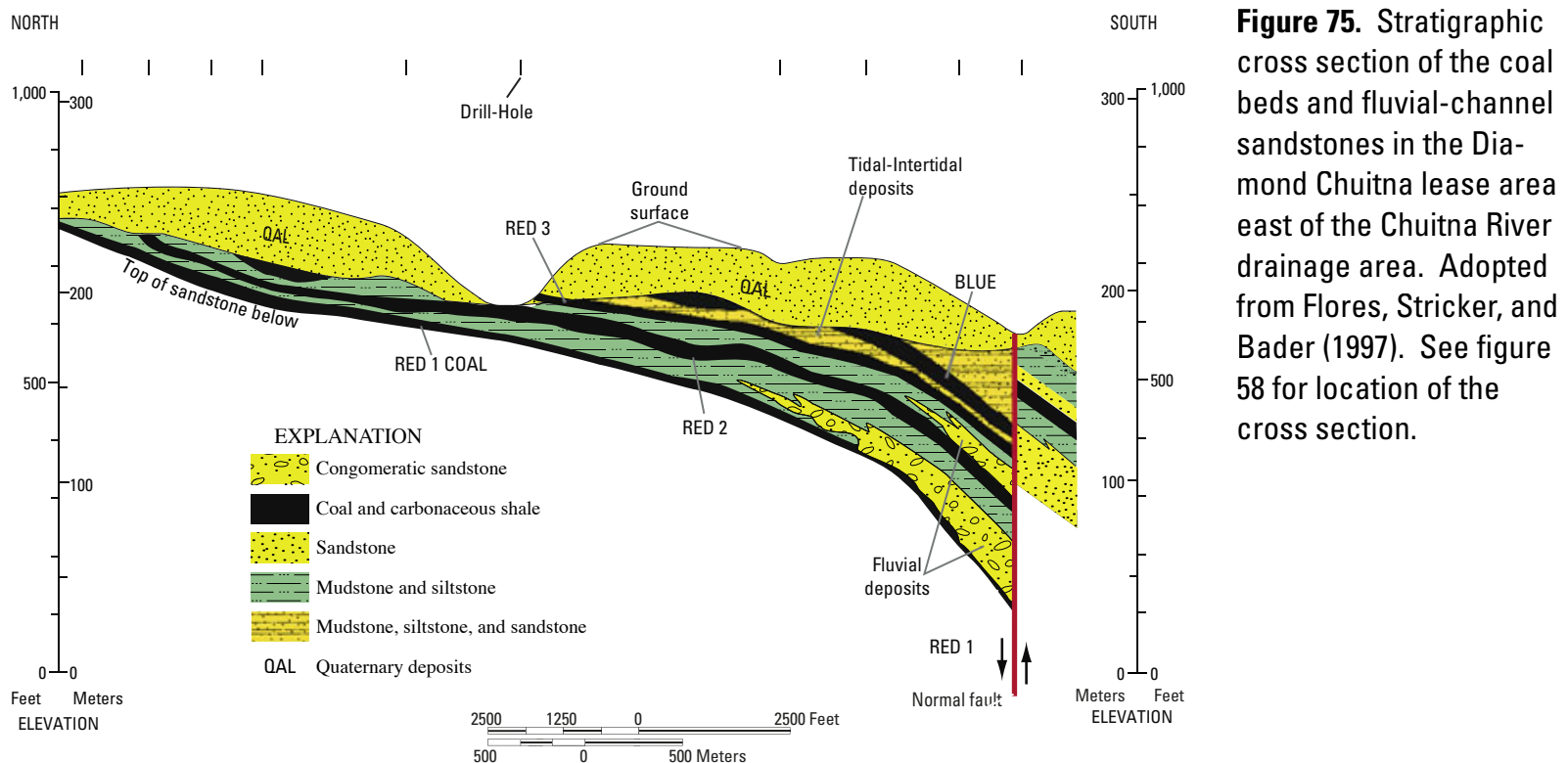

Figure 76. Verti-
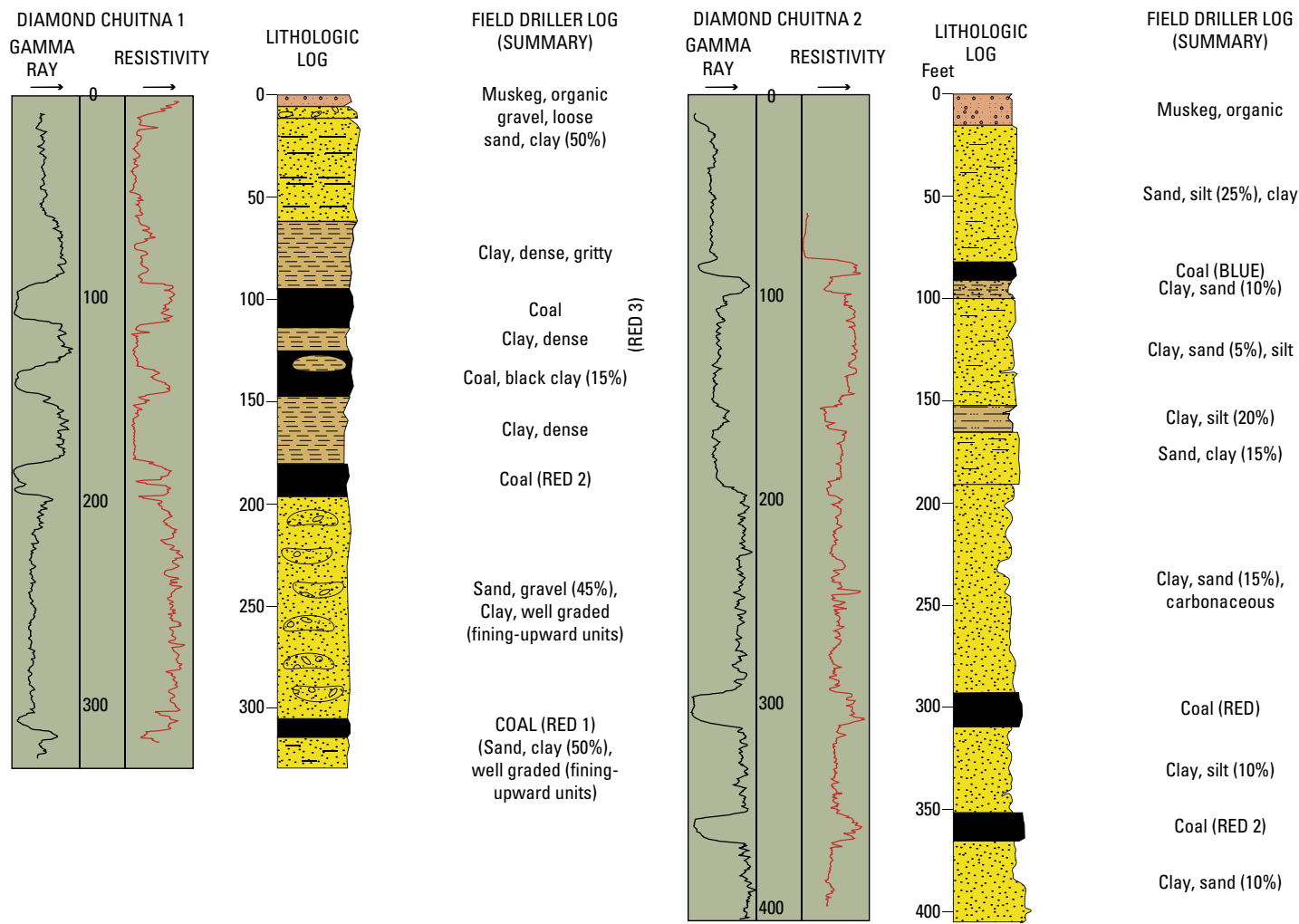

Clay, sand (10\%)

and assor geophysical of minable coa beds (Reds 1, 2, and 3, and Blue) and interbedded fluvial-channel sandstones, and flood plain claystones and siltstones in the Diamond Chuitna lease area east of the Chuitna River drainage area. Adopted from Flores, Stricker, and Stiles (1997).

ELD DRILLER LOG
(SUMMARY)
Muskeg, organic
Coal (BLUE)
Clay, sand (10\%)
lay, sand (5\%), silt
Clay, silt (20\%)
Sand, clay (15\%)
Clay
Clay, sand (10\%)
Clay, silt (10\%)
carbonal (RED)
cand (15\%),




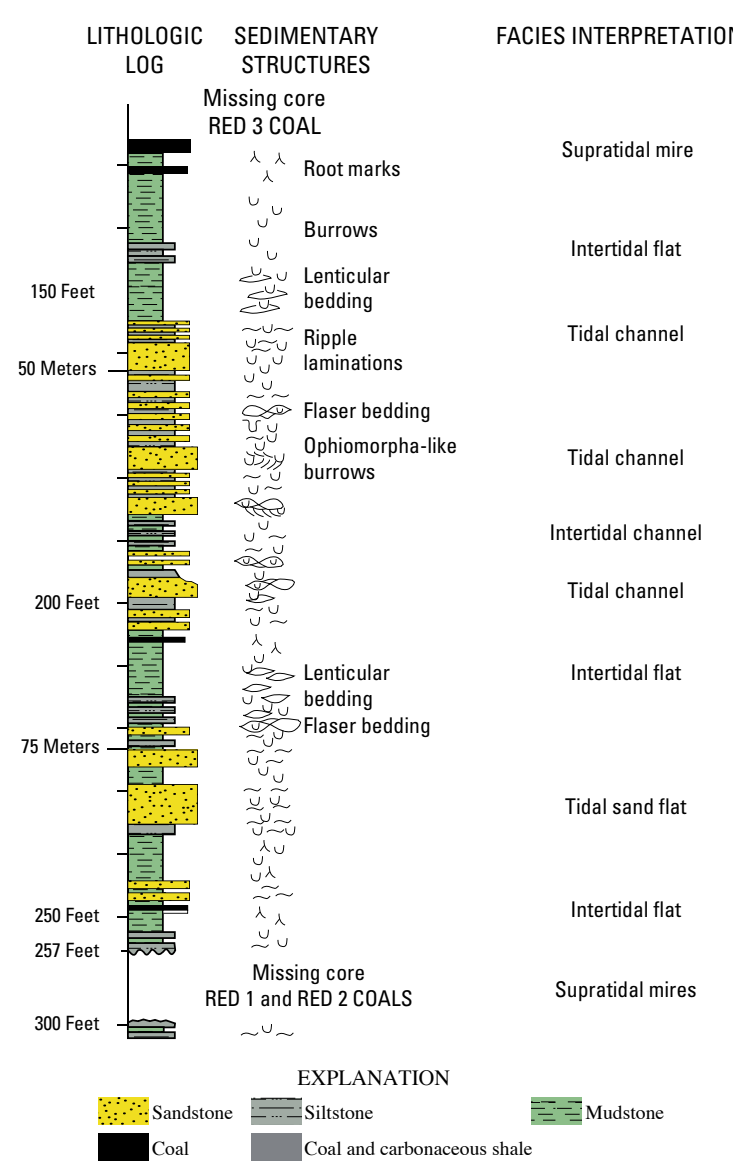

Figure 77. Vertical lithofacies of coal beds (Reds 1, 2, and 3) and interbedded tidal and intertidal sandstones, siltstones, and mudstones in the Diamond Chuitna lease area east of the Chuitna River drainage area. Adopted from Flores, Stricker, and Stiles (1997). See figure 74B for explanation of symbols for sedimentary structures.

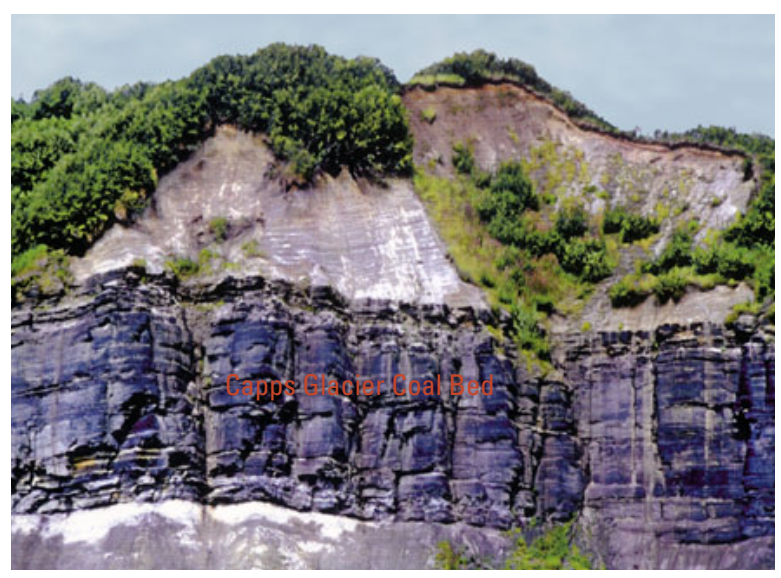

Figure 78. Photograph of the Capps Glacier coal bed ( 50 feet or 15.2 meters thick) and overlying fluvial-channel sandstones in the Capps Glacier area.

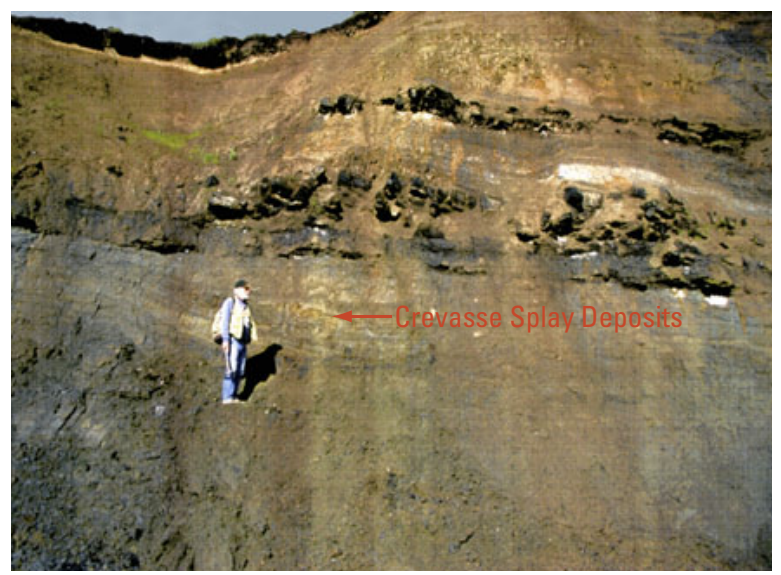

Figure 79. Photograph of the coal beds and interbedded flood-plain/crevasse splay deposits in the Capps Glacier area. Man for scale is about 5.9 feet (1.8 meters) tall.
Figure 80. Structural cross section (northsouth) of the Capps Glacier coal bed and associated rocks of the Tyonek Formation in the Capps Glacier area. See figure 58 for location of the cross section.

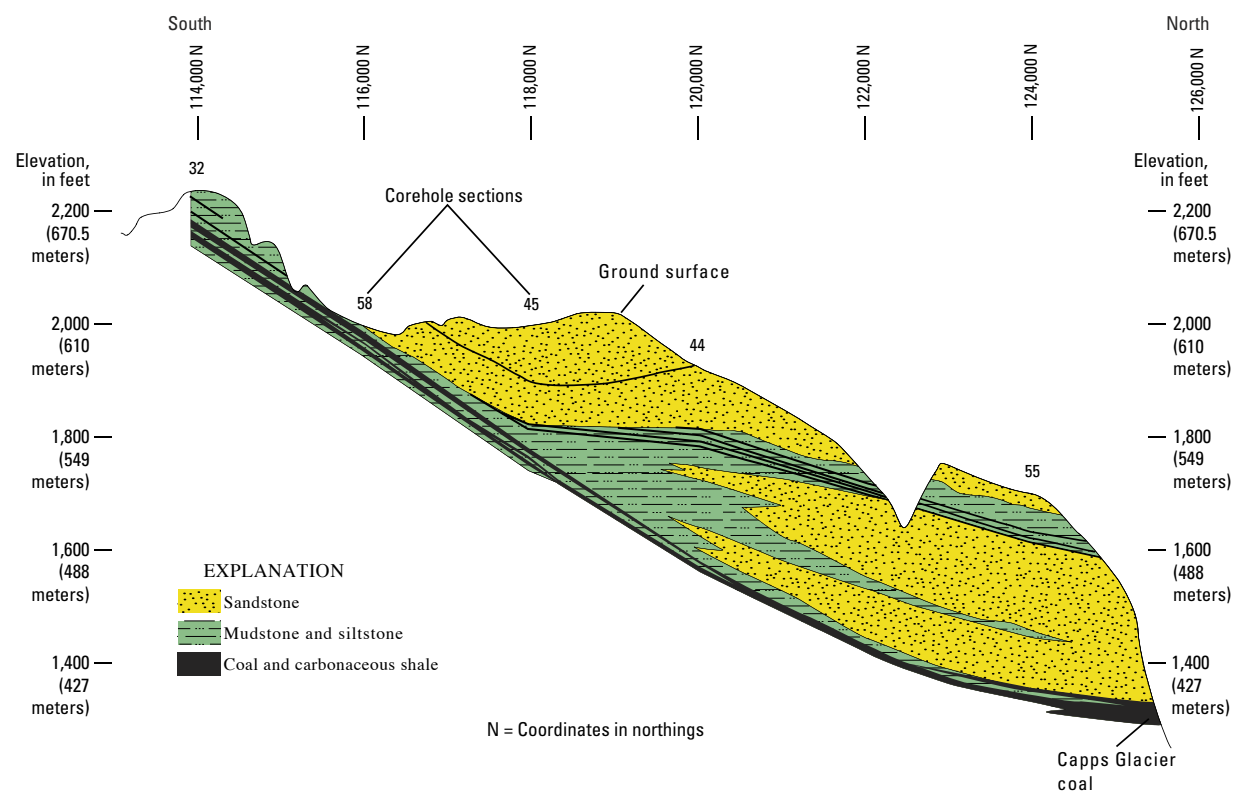




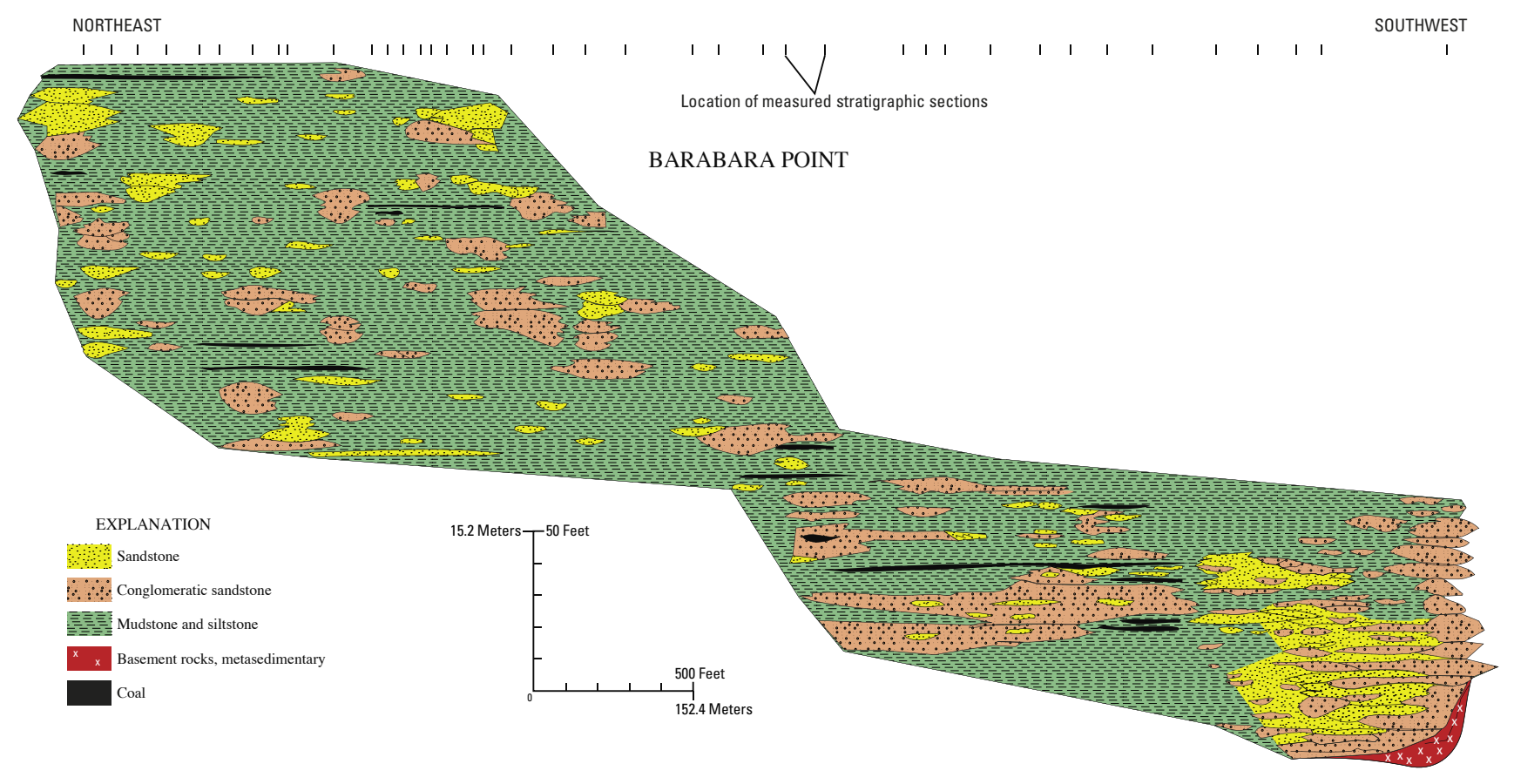

Figure 81. Stratigraphic cross section (northeast-southwest) of the rocks of the Tyonek Formation at Barabara Point showing lenticular conglomerates, sandstone, and coal beds. The sandstone and conglomerate in the southwestern part of the cross section represent paleovalley deposits incised into basement rocks. See figure 58 for location of the cross section.

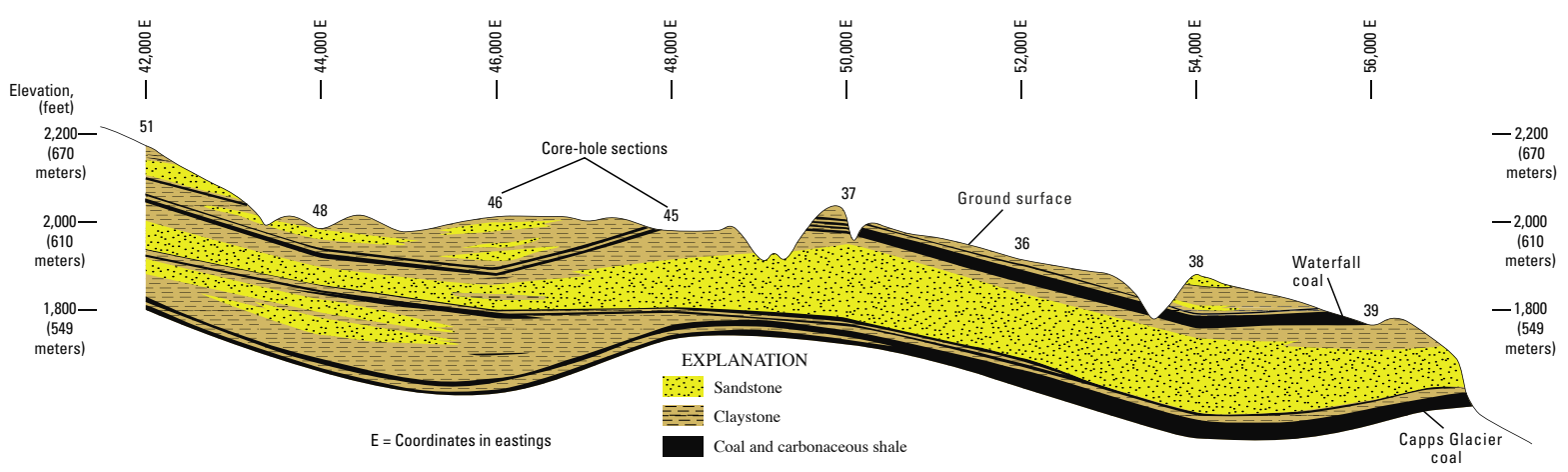

Figure 82. Stratigraphic (structural) cross section of the Capps Glacier coal bed and associated rocks of the Tyonek Formation in the Capps Glacier area. See figure 58 for location of the cross section.

province; Wolfe and Tanai, 1980), have their watershed in the central Alaska interior. The meandering streams were fed by transverse alluvial fans that were better developed along the eastern part of the basin than along the western part. The ancestral Chugach-Kenai uplift was uplifted more than the ancestral Aleutian-Alaska Arc Range (see fig. 87).

\section{Sterling Formation}

The Sterling Formation is as much as $10,990 \mathrm{ft}(3,350 \mathrm{~m})$ thick and consists of sandstones, conglomeratic sandstones, siltstones, mudstones, carbonaceous shales, and coal beds (see fig. 43; Kirschner and Lyon, 1973; Hayes and others, 1976;
Hite, 1976); Hartman and others, 1971; Calderwood and Fackler, 1972). The sandstones are as much as $200 \mathrm{ft}(61 \mathrm{~m})$ thick, fining upward, basally scoured, and multistory (figs. 88 and 89); their vertical and lateral variations are exhibited in figures 90 and 91 . Tonsteins or volcanic ash units are commonly interbedded with the coal beds. Hornblende and volcanogenic hypersthene are abundant in the sandstones. These heavy minerals indicate that the Sterling Formation was probably derived from the ancestral Aleutian-Alaska Arc Range to the west (see fig. 58). Coal beds are generally no more than $3 \mathrm{ft}(1 \mathrm{~m})$ thick, but a few are as thick as $8 \mathrm{ft}(2.5 \mathrm{~m})$ (fig. 92; Barnes and Cobb, 1959; Calderwood and Fackler, 1972). Coal is lignitic throughout much of the formation but is high-volatile subbi- 


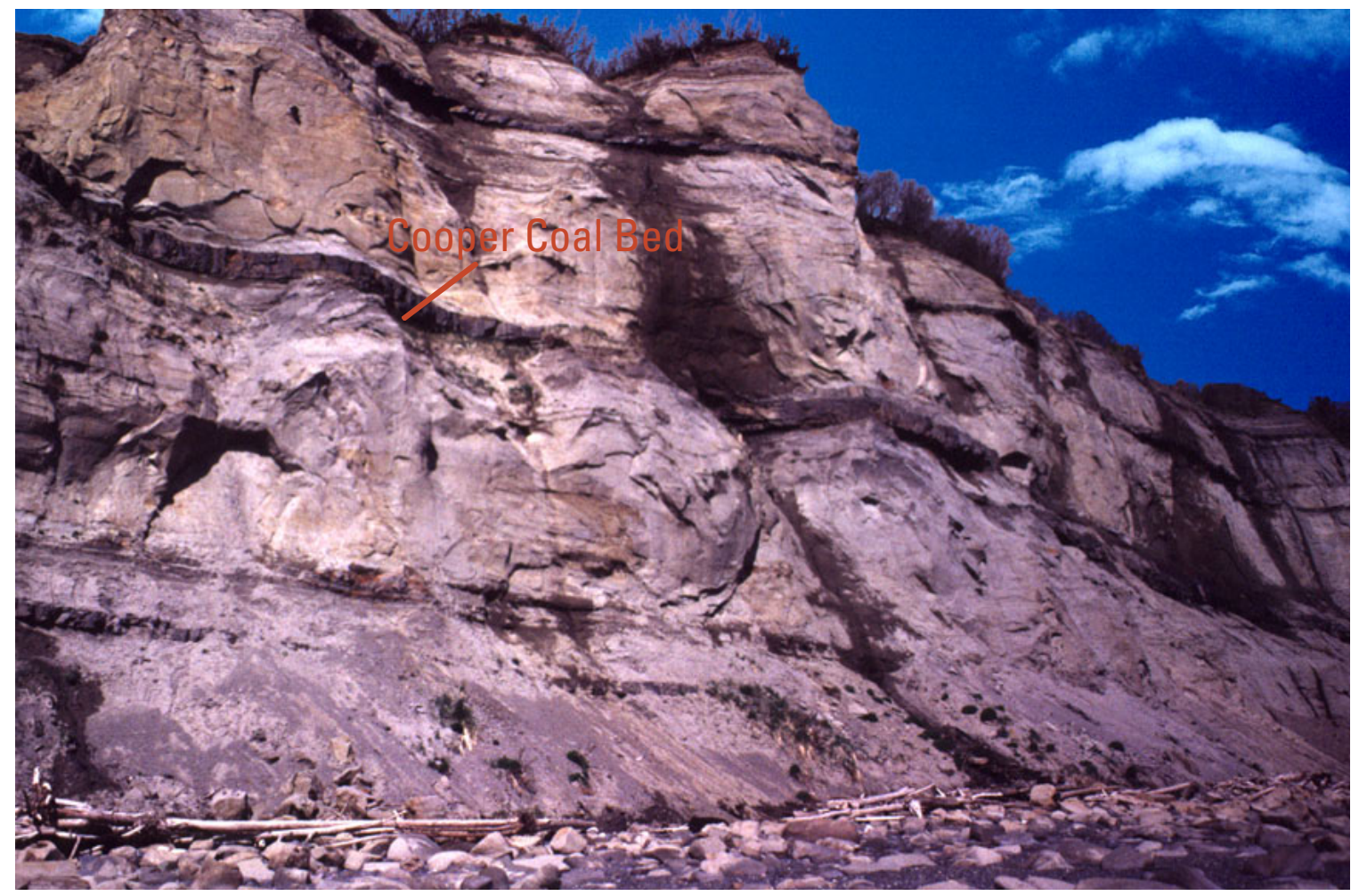

Figure 83. Photograph of the fluvial-channel sandstones (average 60 feet or 18.3 meters thick), flood plain mudstone and siltstones, and coal beds of the Beluga Formation along the coastal bluffs in west Homer, Kenai Peninsula.

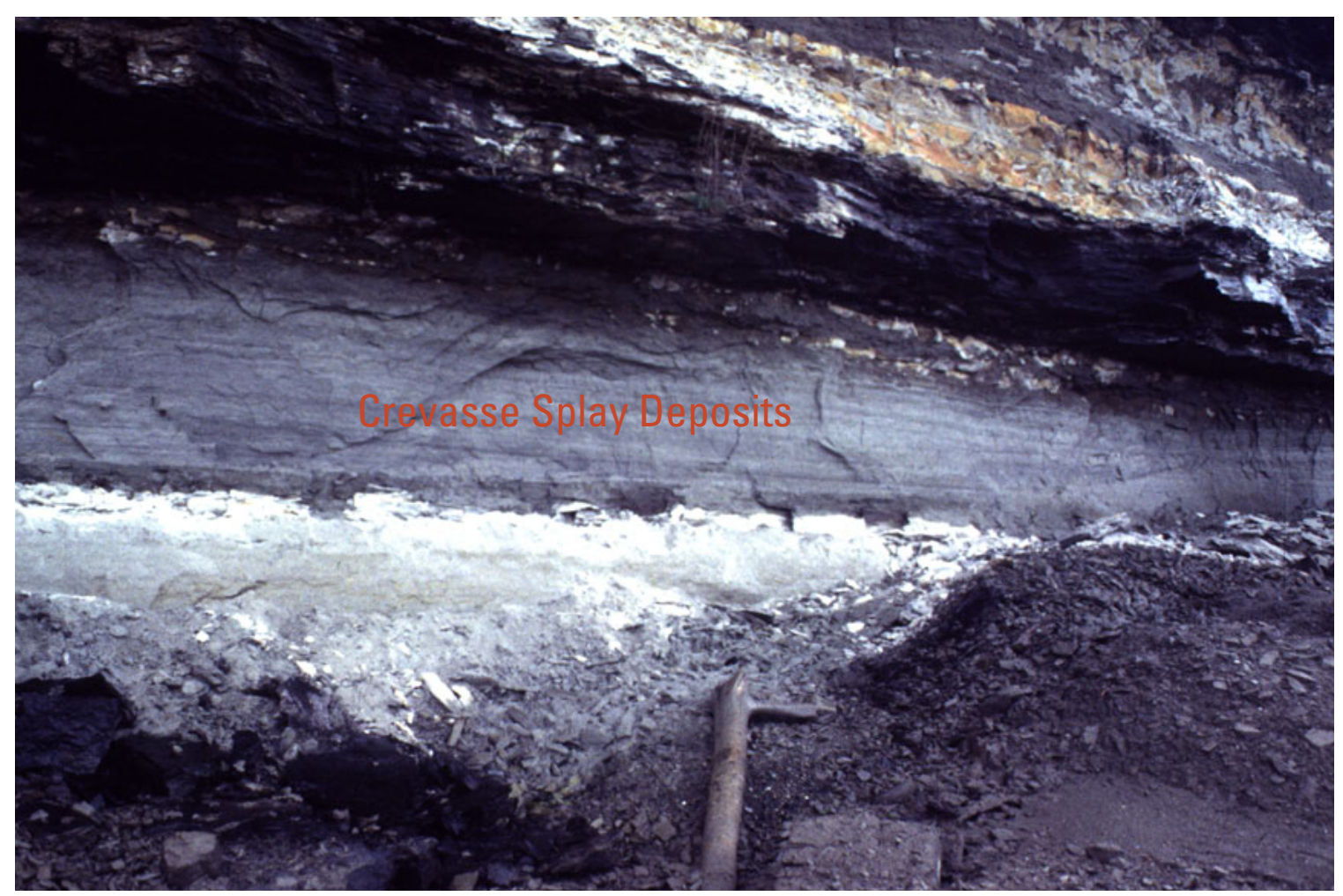

Figure 84. Photograph of a coal bed ( 3.5 feet or 1.1 meters thick) and crevasse splay deposits of the Beluga Formation along the coastal bluffs west of Homer, Kenai Peninsula. 


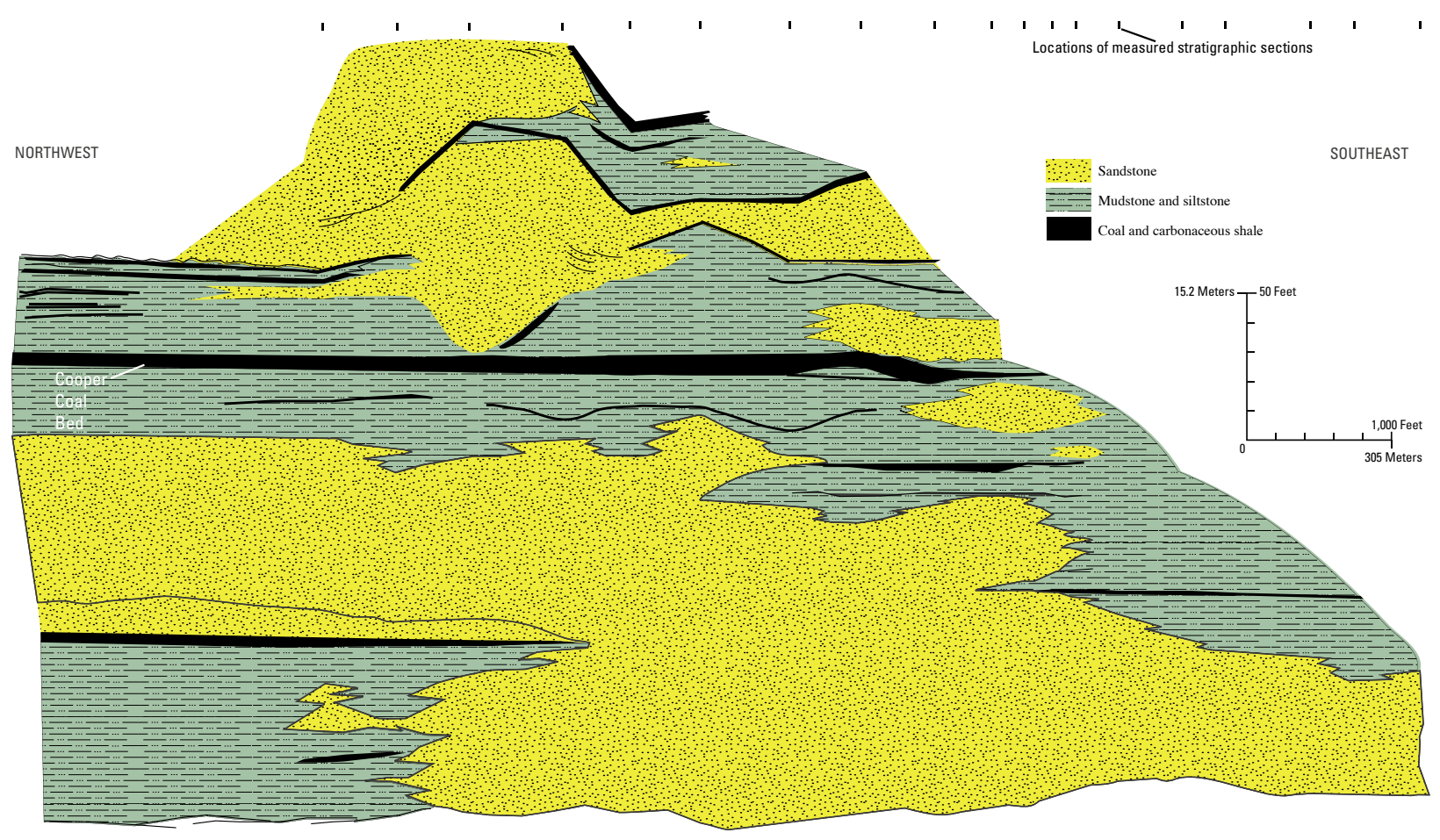

Figure 85. Stratigraphic cross section of the Beluga Formation showing thick coal beds (for example, Cooper coal bed), fluvial-channel sandstones, and flood-plain mudstone and siltstone along the coastal bluffs west of Homer, Kenai Peninsula. Adopted from Flores and Stricker (1993b). See figure 58 for location of the cross section.

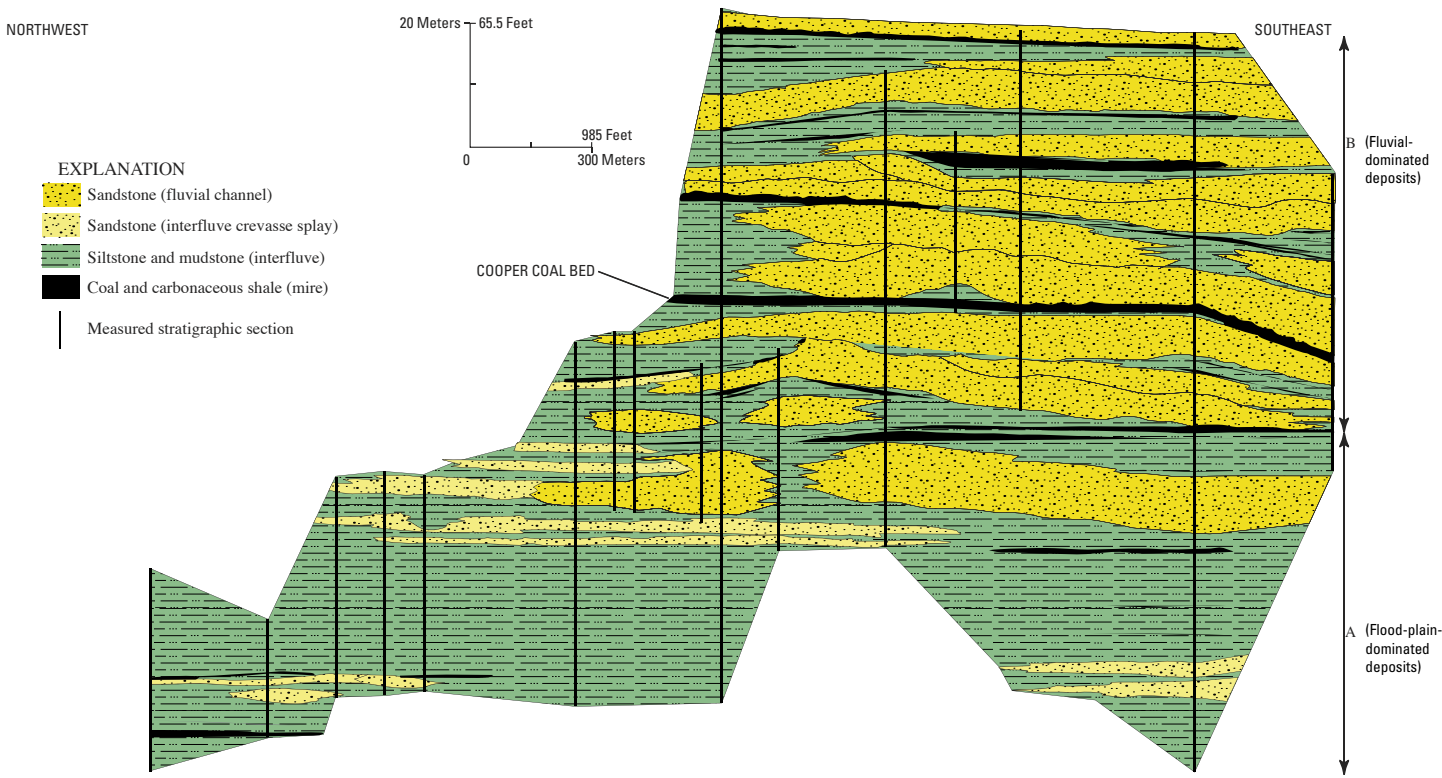

Figure 86. Stratigraphic cross section of the Beluga Formation showing interbedded thin to thick coal beds (for example, Cooper coal bed), fluvial-channel sandstones, and flood-plain deposits along the coastal bluffs west of Homer, Kenai Peninsula. Adopted from Flores and Stricker (1993b). See figure 58 for location of the cross section. 
Figure 87. Paleogeographic map (block diagram) showing depositional environments of the Beluga Formation in the Cook Inlet Basin. Modified from Hayes and others (1976).

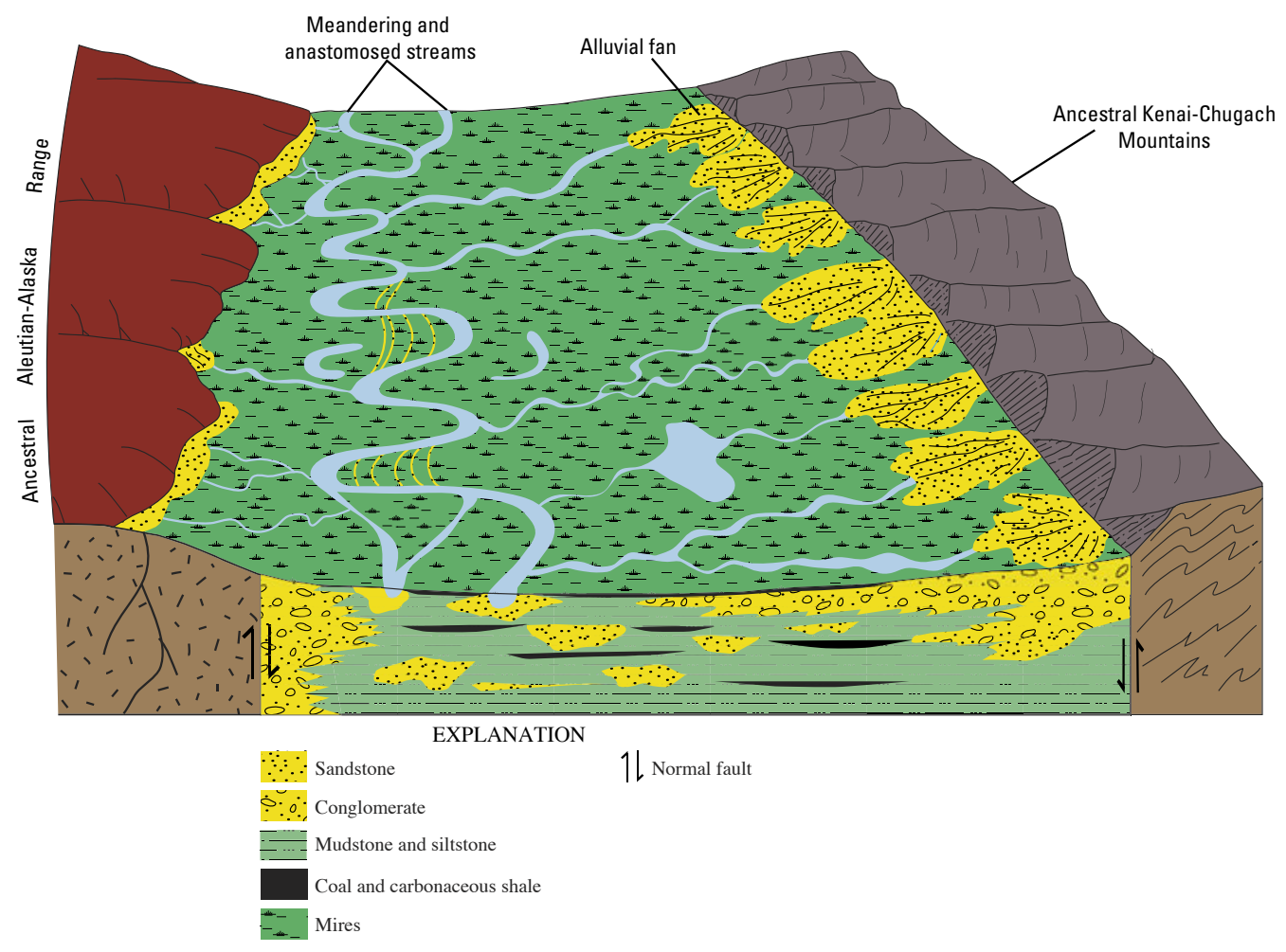

tuminous near the base. The Sterling Formation was dated as latest Miocene and Pliocene age by Wolfe and Tanai (1980).

Hite (1976) and Hayes and others (1976) interpreted the Sterling Formation as being deposited by meandering and braided streams (fig. 93), with the former mainly draining the basin axis and the latter draining the margins of the basin. The braided streams built alluvial fans that were better developed along the western part of the basin than along the eastern part. Flores and Stricker (1993c) interpreted the Sterling Formation as being deposited in low-sinuosity (braided) streams that evolved into high-sinuosity (meandering) streams. A close facies association exists between thick coal beds and deposits of the low-sinuosity streams. Mires in high-sinuosity streams were commonly choked by overbank and flood-plain sediments.

\section{Coalfields:}

\section{Matanuska Coalfield}

The Matanuska coalfield is the most important Paleocene coalfield in Alaska because it contains high-rank minable coal beds. This coalfield occupies a graben along the extent of the Matanuska Valley, between the Talkeetna Mountains on the north and the Chugach Mountains on the south (fig. 94). Coal beds of the Chickaloon Formation are distributed in an area about $62 \mathrm{mi}(100 \mathrm{~km})$ long, from Moose Creek on the west to Anthracite Ridge on the east (Capps, 1927).
Coal districts in the Matanuska coalfield were divided into leases under the Federal Coal Leasing Act of 1915. The Wishbone Hill coal district (about $15 \mathrm{mi}^{2}$ or $38 \mathrm{~km}^{2}$ in area) is on the north side of the coalfield between Moose and Granite Creeks. More than 20 coal beds, with thicknesses exceeding $3 \mathrm{ft}(0.9 \mathrm{~m})$, are known in the Wishbone Hill coal district (Belowich, 1994). There, individual coal beds are as much as $23 \mathrm{ft}(7 \mathrm{~m})$ thick, but average $8 \mathrm{ft}(2.4 \mathrm{~m})$ thick. Mining began in 1917 at the west end of the district. The Federal Government operated the Eska mine in 1917 and started a second coal mine, the Chickaloon, on the Chickaloon River. At one time or another nine mines operated in the Wishbone Hill coal district between 1917 and 1970, and three or four coal mines operated in the Chickaloon-Castle Mountain coal district during the same period of time. The latter district was about $12 \mathrm{mi}^{2}$ (31 $\mathrm{km}^{2}$ ) in the area around the old mining camps in the Chickaloon River Valley. Annual coal production in both districts averaged about 50,000 short tons (45,360 metric tons) from 1917 to $1940,160,000$ short tons $(145,000$ metric tons) from 1940 to 1951 , and about 240,000 short tons $(217,700$ metric tons) from 1952 to 1970 . A total of $3 \times 10^{6}$ short tons $(2.7$ million metric tons) was produced from open pit mines and the rest from underground mines. Total coal production was about $7.7 \times 10^{6}$ short tons $\left(7 \times 10^{6}\right.$ metric tons) between 1915 and 1970 , after which production of oil in the State eliminated the market for coal (Merritt and Belowich, 1984).

Coal beds within the Chickaloon Formation vary in thickness considerably or pinch out altogether within short distances as shown in figures 51, 53, and 55. Correlation of exposure of the Premier coal zone and associated coal beds 


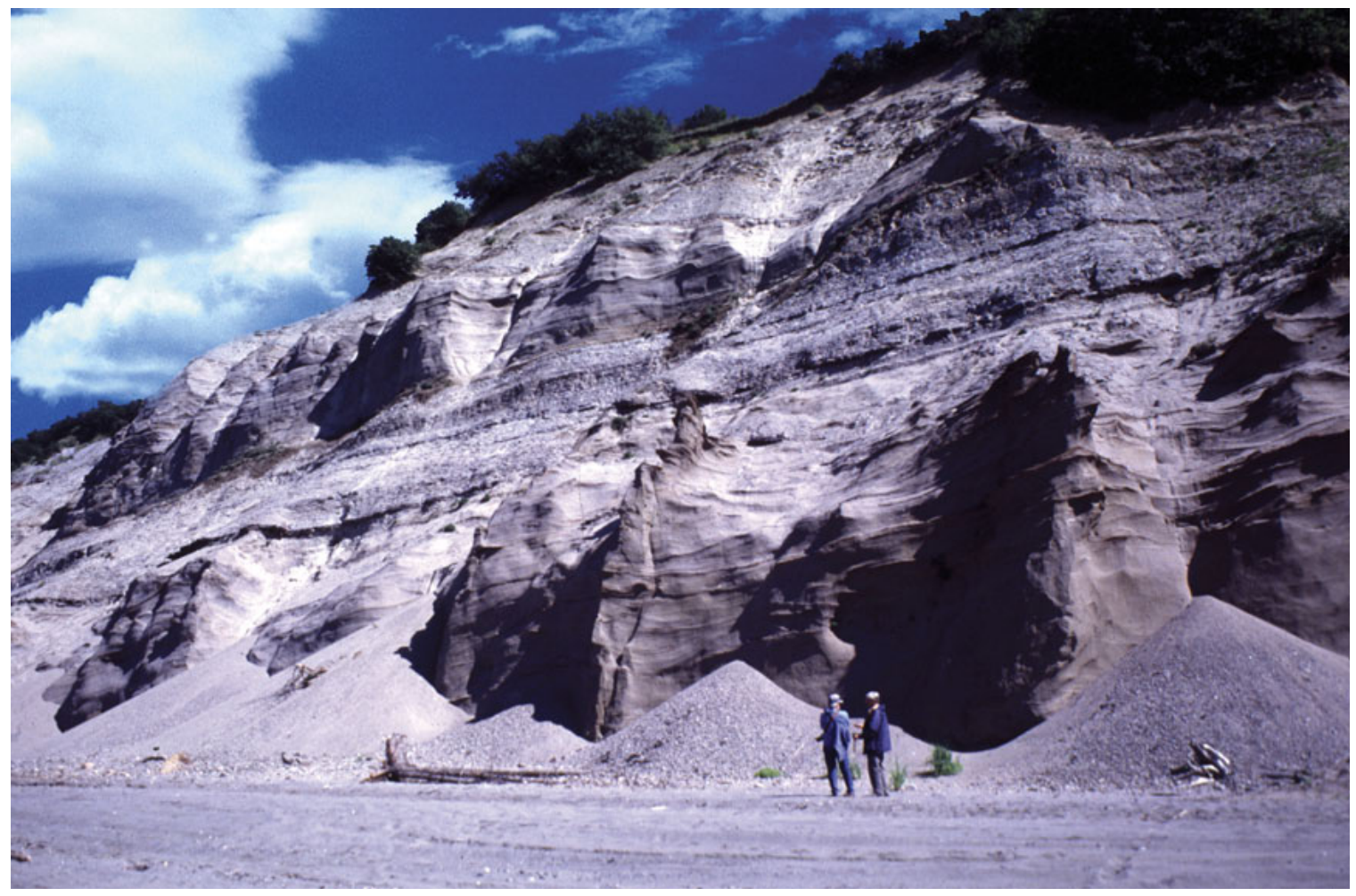

Figure 88. Photograph of fluvial-channel sandstones and thin coal of the Sterling Formation along the coastal bluffs in the Clam Gulch area, Kenai Peninsula. Men are 6 feet (1.8 meters) tall for scale. See figure 58 for location of the cross section.

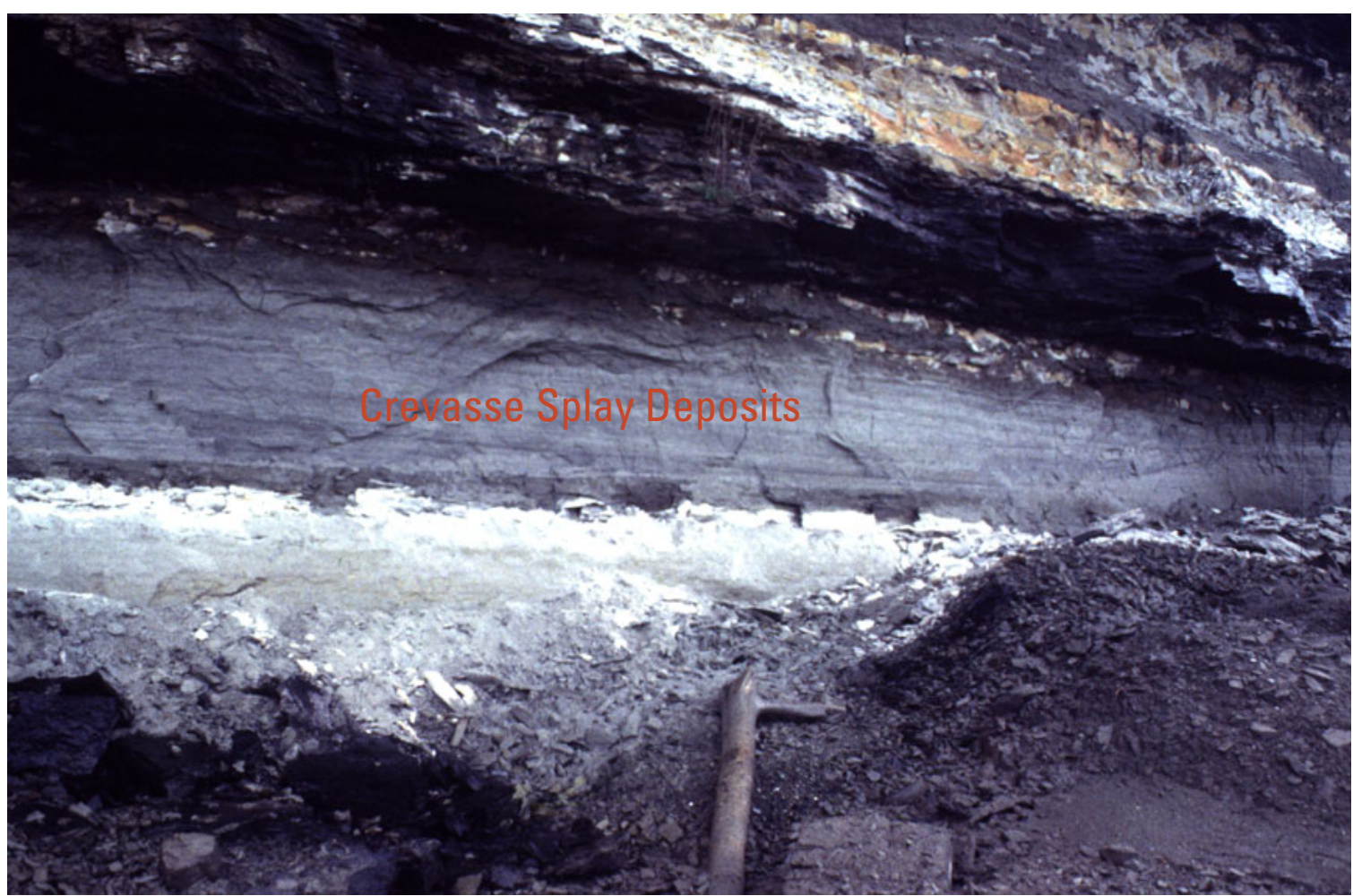

Figure 89. Photograph of fluvial-channel sandstones overlying thin (3 feet [0.9 meter]) to thick (12 feet [3.6 meters]) coal beds of the Sterling Formation along the coastal bluffs between the Clam Gulch and Ninilchik, Kenai Peninsula. 


\section{Alaska Coal Geology, Resources, and Coalbed Methane Potential}

NORTH
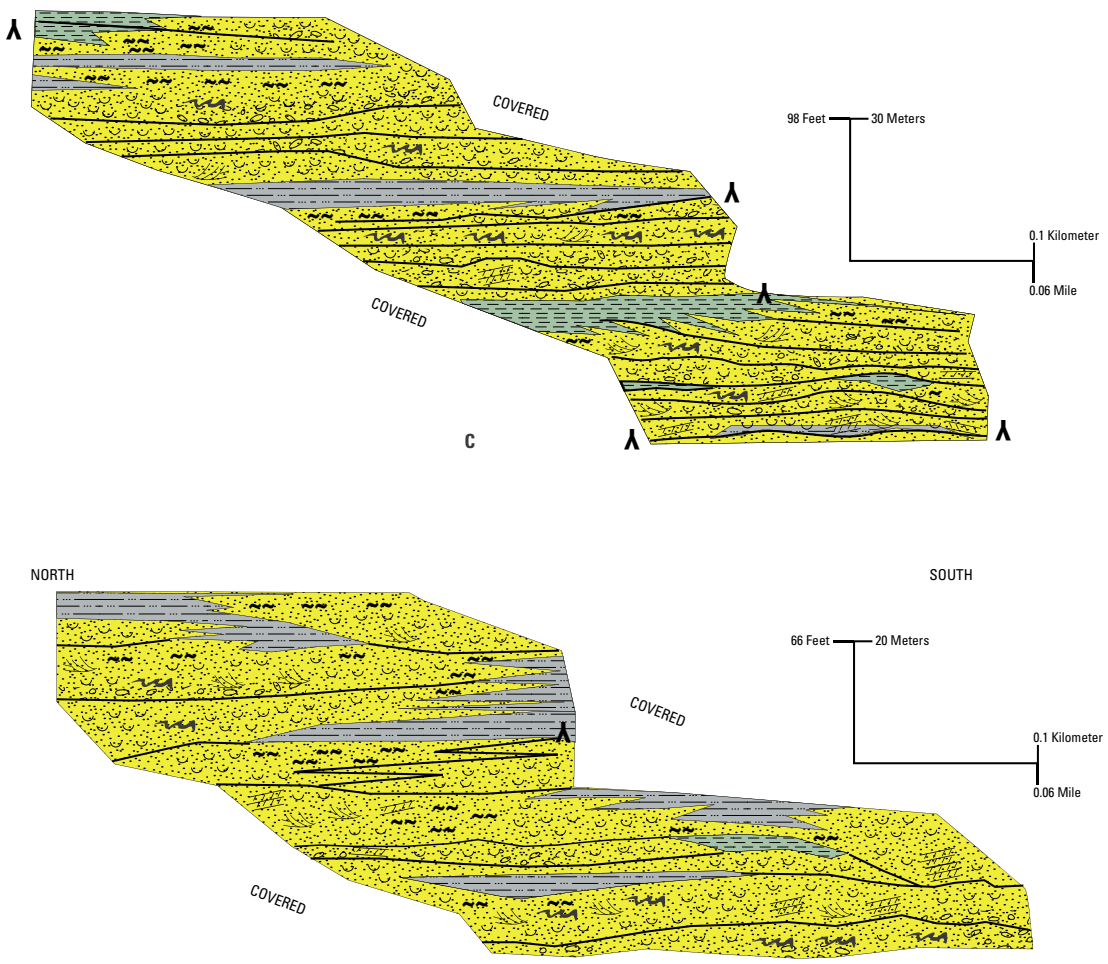

B

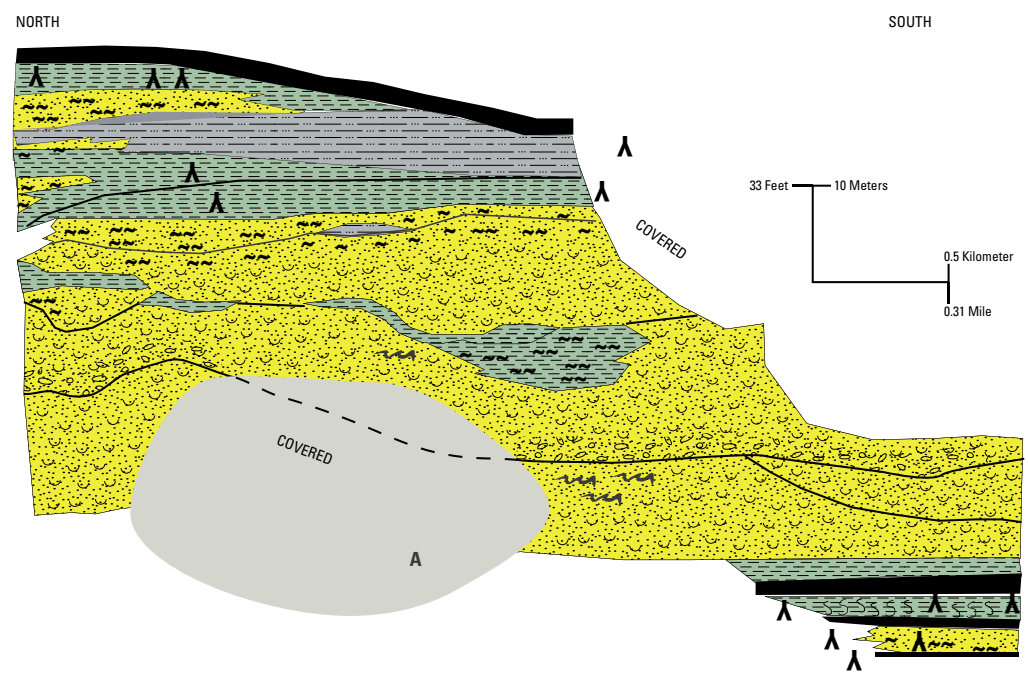

EXPLANATION

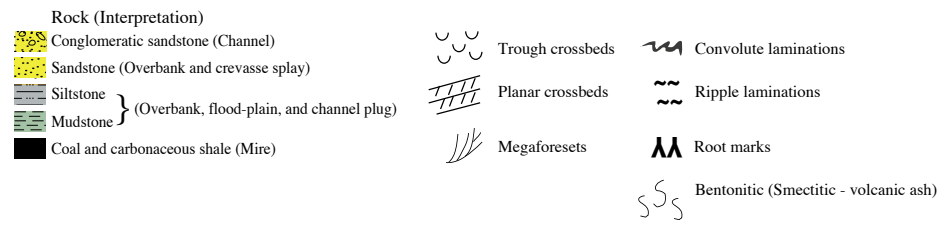

Figure 90. Stratigraphic cross sections showing variations in fluvial-channel architecture in the upper part of the Sterling Formation in the Clam Gulch area, Kenai Peninsula: A, Lower part of Clamgulchian type section; B, Middle part of Clamgulchian type section; C, Upper part of Clamgulchian type section. See figure 58 for location of the cross section. 


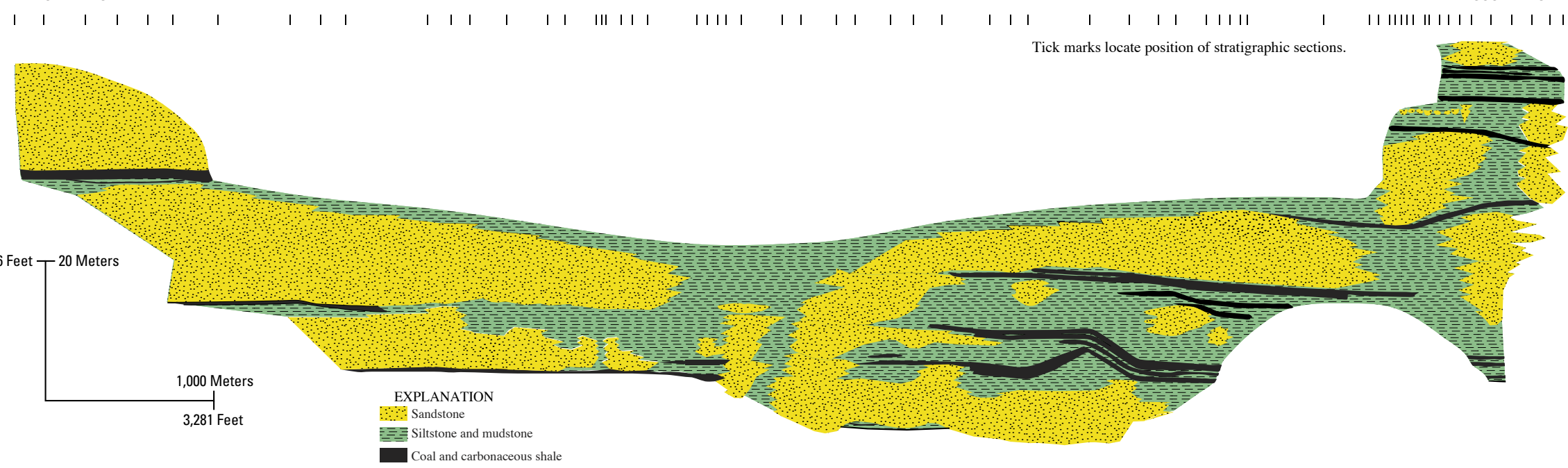

Figure 91. Stratigraphic cross section showing coal beds, fluvial-channel sandstones, and interbedded flood-plain mudstones and siltstones in the lower part of the Sterling Formation between the Clam Gulch area and Ninilchik, Kenai Peninsula. See figure 58 for location of the cross section. 


\section{Alaska Coal Geology, Resources, and Coalbed Methane Potential}

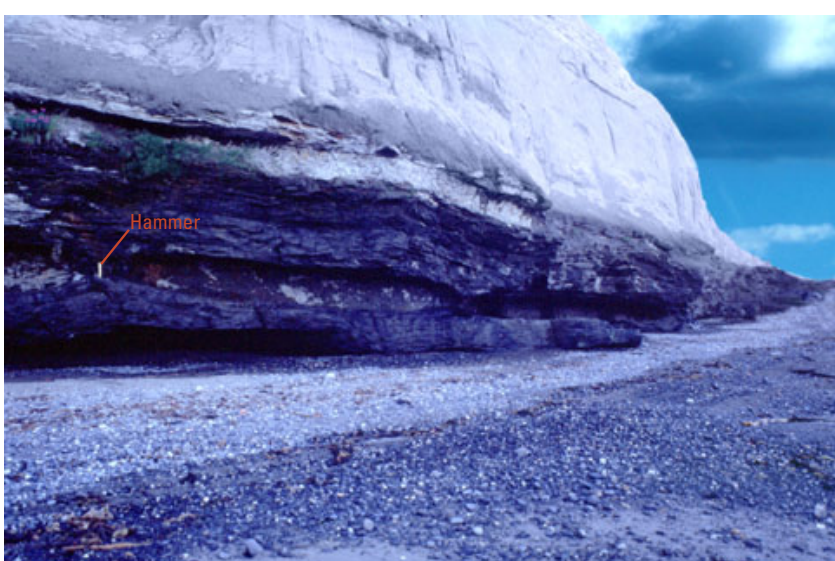

Figure 92. Photograph of thin to thick coal beds in the lower part of the Sterling Formation. Hammer on left of photograph between lower and middle coal beds is 1 foot ( 0.3 meter) long for scale.

was performed by Flores and Stricker (1993a) in the Wishbone Hill district where minable coal beds split and merge over short distances laterally as shown in figure 95. In this coal dis- trict, four groups of minable coal beds, one to six beds in each group, are separated by 49-295 ft (15-90 m) of interburden rock in a section $1,180-1,510 \mathrm{ft}(360-460 \mathrm{~m})$ thick. Combined, 12 minable beds totaled about $49 \mathrm{ft}(15 \mathrm{~m})$ in thickness. The thickest coal bed is about $10 \mathrm{ft}(3.3 \mathrm{~m})$ thick (Barnes and Payne, 1956; Barnes and Sokol, 1959).

Six to 10 coal beds were penetrated by drilling in the Chickaloon coal district, most less than $3 \mathrm{ft}(1 \mathrm{~m})$ thick, but one bed is more than $14 \mathrm{ft}(4.3 \mathrm{~m})$ thick. The beds are lenticular and vary in thickness within 197-295 ft (60-90 m) laterally, making correlations, reserve calculations, and prospecting across transverse faults difficult.

The Anthracite Ridge coal district covers about $30 \mathrm{mi}^{2}$ $\left(77 \mathrm{~km}^{2}\right)$ at the eastern end of the coalfield (fig. 94). The number of coal beds in this district is uncertain owing to poor exposures and complex structure. A few beds in the coal district are as thick as 3.9-6.5 ft $(1.2-2.0 \mathrm{~m})$ and one reaches $39 \mathrm{ft}(12 \mathrm{~m})$; the coal beds are exceptionally lenticular.

The intensity of deformation and abundance of igneous dikes and sills in the Chickaloon Formation increase eastward along the Matanuska coalfield. A few small dikes occur in the Wishbone Hill coal district, and thick sills are abundant in the Anthracite Ridge coal district. Heating induced by the igneous intrusions may be the main reason for the increase in coal rank

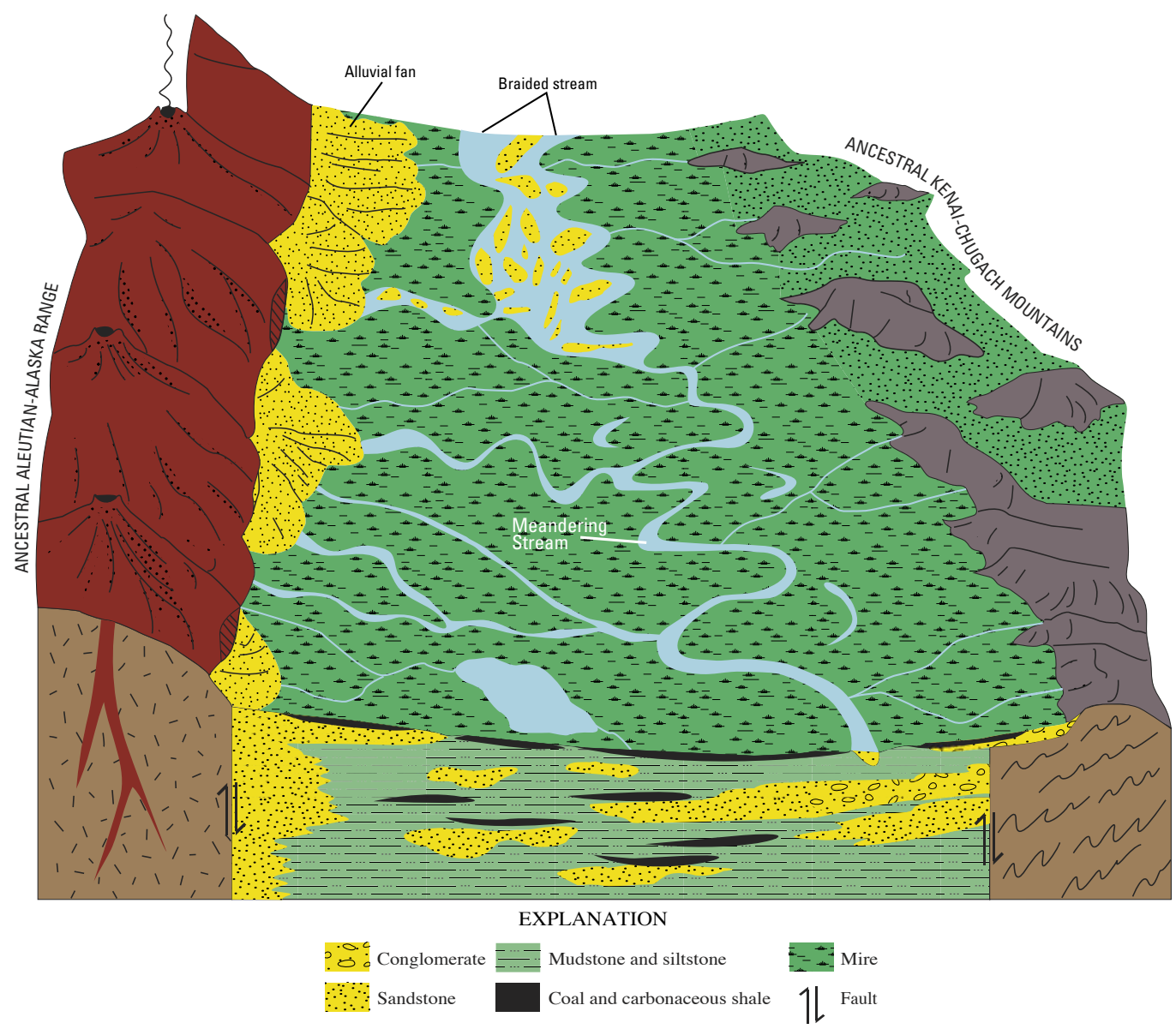

Figure 93. Block diagram showing depositional environments of the Sterling Formation in the Cook Inlet Basin. Modified from Hayes and others (1976). 


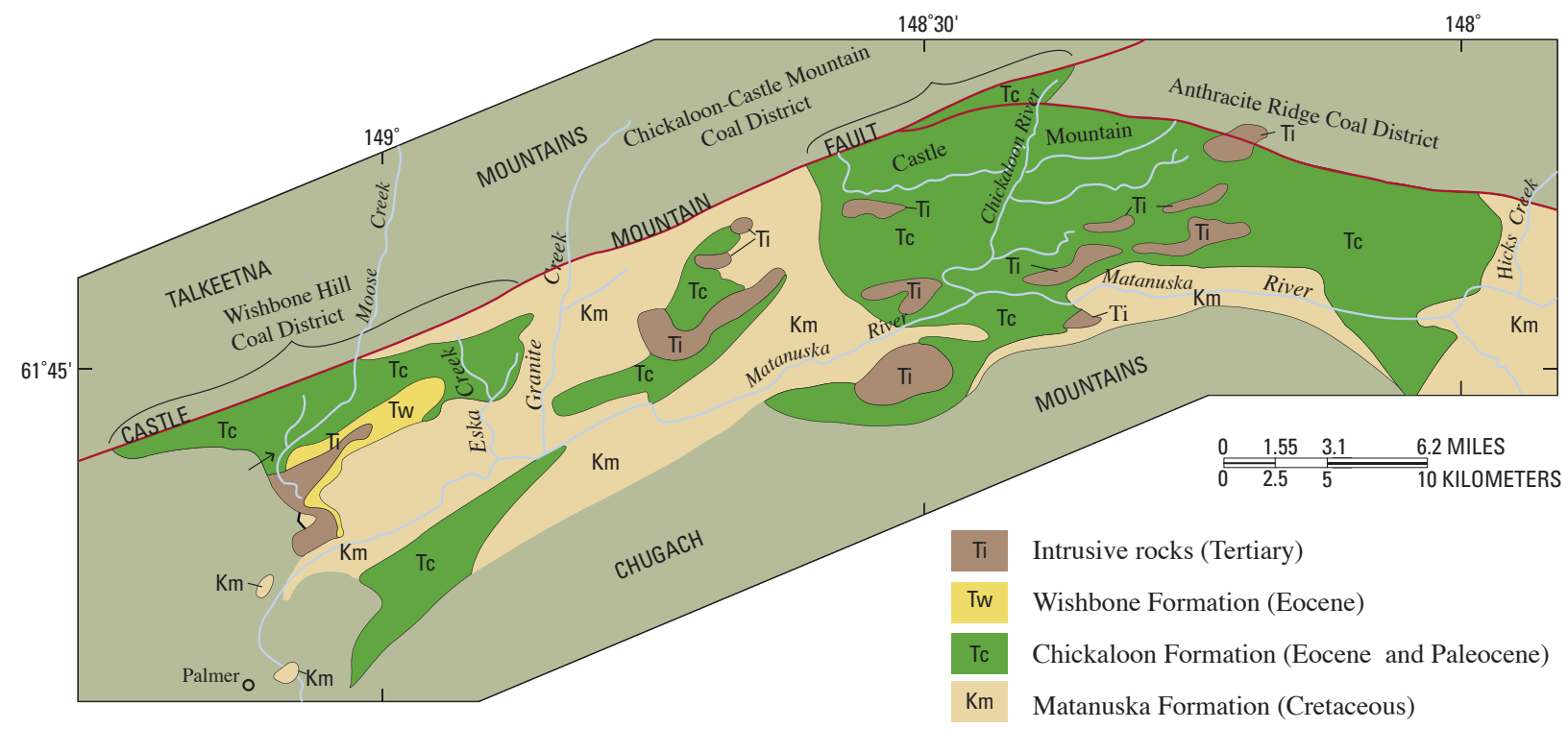

Figure 94. Map showing the geology and coal districts in the Matanuska coalfield.

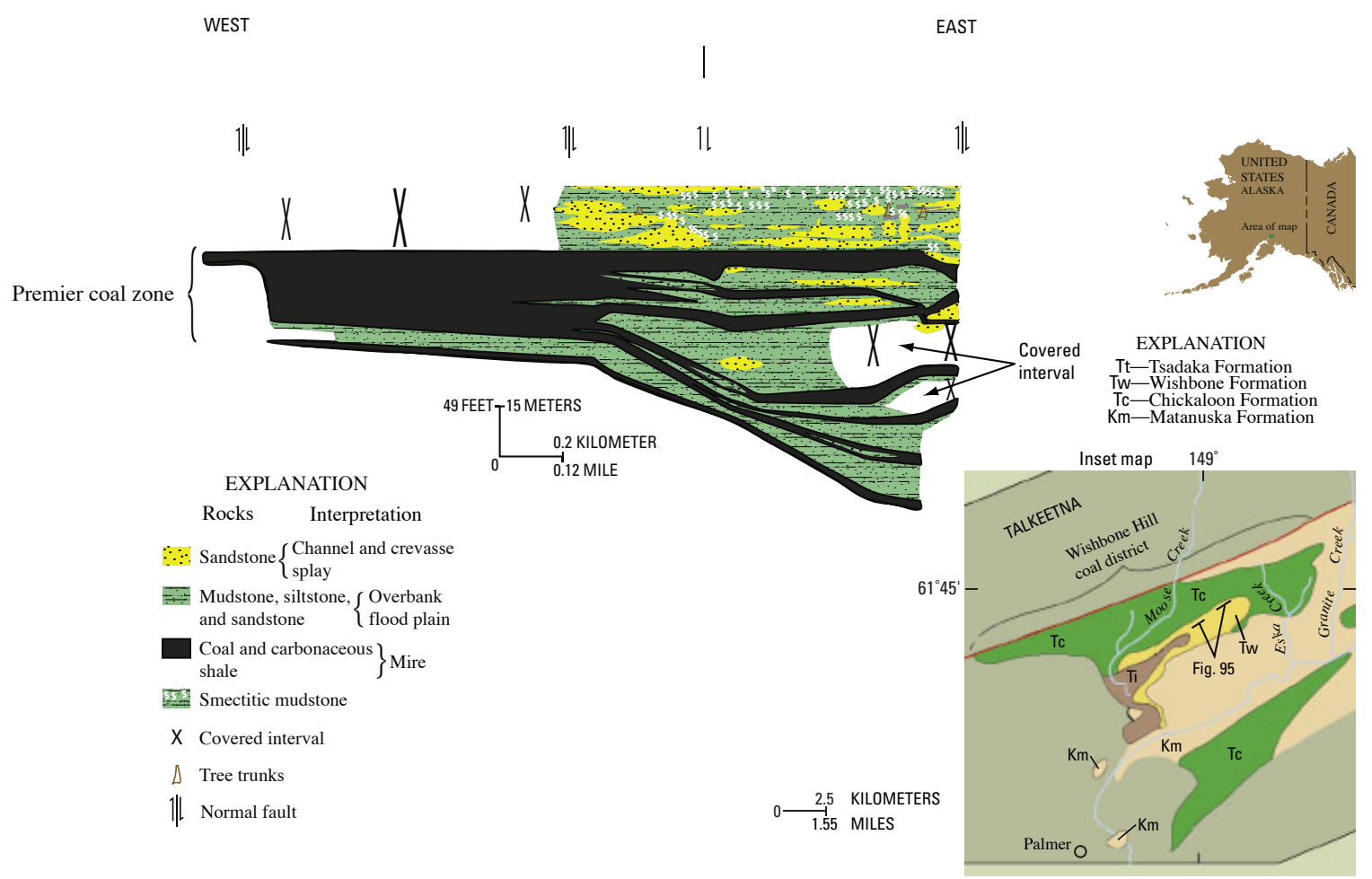

Figure 95. Cross section of the Premier coal zone of the Chickaloon Formation in the Wishbone Hill coal district. Modified from Flores and Stricker (1993d). See figure 96 for location of cross section. 


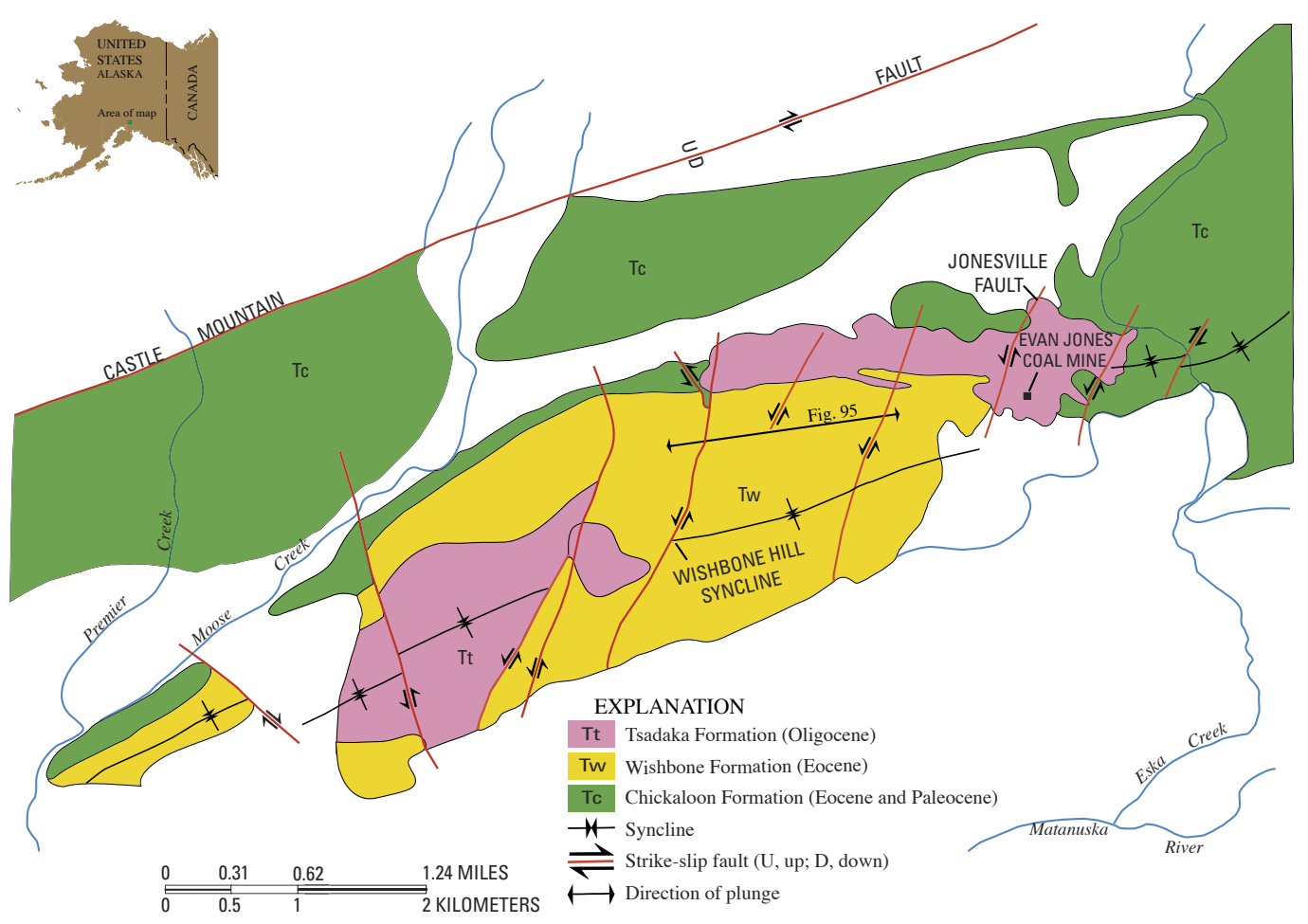

Figure 96. Geologic map of the Wishbone Hill coal district showing doubly plunging syncline disrupted by normal faults. Modified from Flores and Stricker (1993a).

from subbituminous to anthracite eastward in the coalfield. However, Barnes (1962) suggested that heat generated by tectonic activity was more important than that from igneous intrusions. Merritt (1985) described the natural coking of coal adjacent to an intrusive diabase sill in which the contact temperature reached $1,020^{\circ} \mathrm{F}\left(550^{\circ} \mathrm{C}\right)$. The coal bed along the contact was locally coked and raised to semianthracite, but about $165 \mathrm{ft}(50 \mathrm{~m})$ away from the contact, the coal was ranked high-volatile bituminous A. The coal rank in the Anthracite Ridge coal district also changes abruptly from low-volatile bituminous to semianthracite or anthracite within about $196 \mathrm{ft}$ (60 m) toward an intrusion (see fig. 40; Waring, 1936).

Structures in the Matanuska coalfield are typically complex. The doubly plunging Wishbone Hill syncline, a relatively simple structure, has beds that dip $20^{\circ}-40^{\circ}$ on either flank; the structure is cut by two sets of transverse faults (fig. 96). Structural complications on its northwest flank make the coal beds in some structural blocks difficult to mine and preclude meaningful estimation of reserves (Barnes and Payne, 1956). With the possible exception of the Castle Mountain district, structural complexities increase eastward. In the Chickaloon district, beds dip as much as $90^{\circ}$; in the Chickaloon mine, coal beds are overturned (Chapin, 1920) and faulted. Large areas of the Chickaloon Formation are covered by a thick mantle of glacial till and crop out only along stream bluffs (Capps, 1927). Anthracite occurrences on the south flank of Anthracite Ridge are bordered on the north by a high-angle fault of large displacement and are in tightly folded and locally overturned synclines cut by many faults.

\section{Susitna-Beluga Coalfield}

The Susitna-Beluga coalfield is situated in the Susitna Lowland (see fig. 40) north of the Cook Inlet between the Talkeetna Mountains on the east and the Alaska Range on the north and west. Glacial and alluvial deposits mainly cover the Susitna Lowland. Coal beds are in the Kenai Group. The rocks are exposed in isolated areas but mainly along the banks and tributaries of the Susitna, Yentna, Beluga, and Chuitna Rivers. These coal-bearing rocks underlie an area of at least 3,440 $\mathrm{mi}^{2}\left(8,910 \mathrm{~km}^{2}\right)$. Barnes (1967a) studied these exposures and concluded that the potentially minable coal beds are located in a $400-\mathrm{mi}^{2}\left(1,036-\mathrm{km}^{2}\right)$ area at the southwestern end of the coalfield in the drainage basins of the Chuitna and Beluga Rivers. There, the coal beds range from lignite to subbituminous and range from a few inches (few centimeters) to more than $50 \mathrm{ft}(15 \mathrm{~m})$ thick. Barnes (1967a) has traced a few of the thick (30-50 ft or 9.1-15 m) coal beds for distances of more than $7 \mathrm{mi}(11 \mathrm{~km})$ along the course of the Chuitna River. Flores and others (1994) and Flores, Stricker, and Stiles (1997) have described the lateral variations of these coal beds, which are shown in figures 73, 74, and 75. Myers and others (1998) traced one $50-\mathrm{ft}(15-\mathrm{m})$ coal for $4 \mathrm{mi}(6.4 \mathrm{~km})$ in the Capps Glacier area (see fig. 40). Other thick (10-25 ft or 3-7.6 m) coal beds are exposed along the Beluga, Skwentna, and Yentna Rivers (see fig. 40). Along the southeast margin of the Alaska Range, the Kenai Group rocks lie in downfaulted or downwarped basins (Barnes, 1966; Magoon and others, 1976; Reed and Nelson, 1980). 
Reed and Nelson (1980) divided the Tyonek Formation in the Susitna-Beluga coalfield into two members. The basal member consists of 40 percent conglomerate, 20 percent sandstone, and 40 percent siltstone, claystone, and coal; the latter are in beds as much as $56 \mathrm{ft}(17 \mathrm{~m})$ thick. The overlying member consists predominantly of sandstones about $558 \mathrm{ft}$ $(170 \mathrm{~m})$ thick, composed of repetitive cycles $23-75 \mathrm{ft}$ (7-23 $\mathrm{m}$ ) thick and grading from coarse-grained, pebbly sandstone at the base to silt and clay with coal or bony coal at the top. The Tyonek is overlain by the Sterling Formation, consisting of an orange to light gray, massive pebble to boulder conglomerate, as much as $2,525 \mathrm{ft}$ (770 m) thick.

Barnes (1966) reported two negative gravity anomalies beneath the Susitna Lowland-one between Johnson Creek and Yenlo Mountain and north of the Skwentna River, and the other between Yenlo Mountain and the Susitna River, centered at the confluence of the Kahiltna and Yentna Rivers (see fig. 40). Barnes interpreted both anomalies as thick fill of the Kenai Group that may contain potential for large deposits of coal.

\section{Broad Pass Coalfield}

The Broad Pass coalfield underlies a narrow trough extending northeastward from south of the divide of the Alaska Range, on the headwaters of the Chulitna River (see fig. 40), to the north end of the Cook Inlet-Susitna Lowland (Wahrhaftig, 1965; Barnes, 1967a). The coalfield is about $5 \mathrm{mi}$ $(8 \mathrm{~km})$ wide and is bordered by mountains that rise abruptly to elevations of about 3,300-8,200 ft (1,000-2,500 m). Although Mesozoic and older metamorphic and igneous rocks are mainly exposed in the coalfield, several small areas of coalbearing rocks of the Kenai Group occur. Only two of these areas are known to contain coal resources: Costello Creek and Broad Pass Station on the Alaska Railroad (see figs. 1 and 40). Only a $7-\mathrm{mi}^{2}\left(18-\mathrm{km}^{2}\right)$ area was mapped with coal-bearing rocks in the Costello Creek and a $1.5-\mathrm{mi}^{2}\left(3.8-\mathrm{km}^{2}\right)$ area near the Broad Pass Station. A detailed U.S. Bureau of Mines-U.S. Geological Survey investigation in the Costello Creek area disclosed a lower unit of interbedded sandstone, mudstone, and coal beds, 0-85 ft (0-26 m) thick, overlain by an upper, predominantly sandstone unit, as much as $490 \mathrm{ft}(150 \mathrm{~m})$ thick, lacking coal beds (Wahrhaftig, 1944).

The coal beds at the Broad Pass Station, 8-10 mi (13-16 km) east of the Costello Creek area, are interbedded with white to orange sandstones and gravelly conglomerates (Hopkins, 1951). These coal beds are correlated to the Sterling Formation of the Susitna-Beluga coalfield. Coal has been reported south of these areas along the Chulitna River. The coalfield contains orange to yellow gravels exposed in railroad cuts and streambanks, which resemble the Nenana Gravel in the Central Alaska-Nenana coal province and the Sterling Formation of the Susitna Lowland.

\section{Kenai Coalfield}

The Kenai coalfield lies on the lowland between the Kenai Mountains on the east and the Cook Inlet on the west, in the western part of Kenai Peninsula (see fig. 40). The coalfield contains the thick, coal-bearing Beluga and Sterling Formations of the Kenai Group and is divided into two coal districts: the northern Kenai and southern Homer coal districts (Barnes, 1967a). The northern Kenai coal district includes mainly outcrops of the Sterling Formation, and the coal beds are exposed mainly along the coastal bluff from north of Clam Gulch to south of Ninilchik (see figs. 58 and 97; Merritt and others, 1987). The coal beds are mainly thin in the upper part and thicker in the lower part of the formation. The Homer coal district contains outcrops of both the Beluga and Sterling Formations, which are mainly exposed along the coastal bluffs from north of Anchor Point to Homer and along the north shore of Kachemak Bay (see figs. 58 and 98) on the southern end of the Kenai Peninsula. The coal-bearing rocks are completely concealed by as much as several hundred feet of glacial and alluvial deposits, particularly in the northern Kenai coal district. However, where the Sterling coal beds are exposed along the coastal bluffs, they are as thick as $12 \mathrm{ft}(3.8 \mathrm{~m})$ and are laterally continuous for more than $1.75 \mathrm{mi}(3 \mathrm{~km})$ (Flores and Stricker, 1992).

The Homer coal district (Barnes and Cobb, 1959) is about $1,200 \mathrm{mi}^{2}\left(3,110 \mathrm{~km}^{2}\right)$ in area and includes as much as $5,000 \mathrm{ft}(1,525 \mathrm{~m})$ of the Beluga and Sterling Formations. These formations contain at least 30 coal beds ranging individually from 3 to $7 \mathrm{ft}$ (0.9 to $2.1 \mathrm{~m}$ ) in thickness (Barnes, 1967a). Flores and Stricker (1993b) reported that Beluga coal beds range from a few inches (few centimeters) to $8.2 \mathrm{ft}$ $(2.5 \mathrm{~m})$ thick and average $3.2 \mathrm{ft}(1 \mathrm{~m})$ (fig. 99). Thin coal beds, a few inches to $1 \mathrm{ft}$ (a few centimeters to $30 \mathrm{~cm}$ ) are traceable laterally from a few tens to hundreds of feet. Thicker coal beds, greater than $2 \mathrm{ft}(>0.6 \mathrm{~m})$, are traceable laterally as much as a few miles. The thickness-to-length ratio of coal beds indicates they vary from lenticular (1:9) to elongate $(1: 1,000-3,000)$. Stratigraphic variations of the coal beds in the Homer coal district are shown in figures 100 and 101. Coal beds of the Beluga Formation are thick and laterally continuous where they are interbedded with thick and extensive sandstones, which were deposited by meandering streams (see fig. 100). Beluga Formation coal beds are thin and discontinuous where interbedded with thin and lenticular sandstones, in which case anastomosed streams (see fig. 101) deposited the sandstones.

Coal was mined intermittently since 1888 along the north shore of Kachemak Bay by the Alaska Coal Company at Miller's Landing northwest of Homer (Barnes, 1967a). In 1891, the U.S. Navy mined 50 short tons (45 metric tons) from four localities on Kachemak Bay. In 1894, the North Pacific Mining and Transportation Company began development in Eastland Canyon (about 1 mi northeast of Kachemak Bay). At least 650 short tons (590 metric tons) of coal was produced from this underground mine and shipped to San Francisco. 


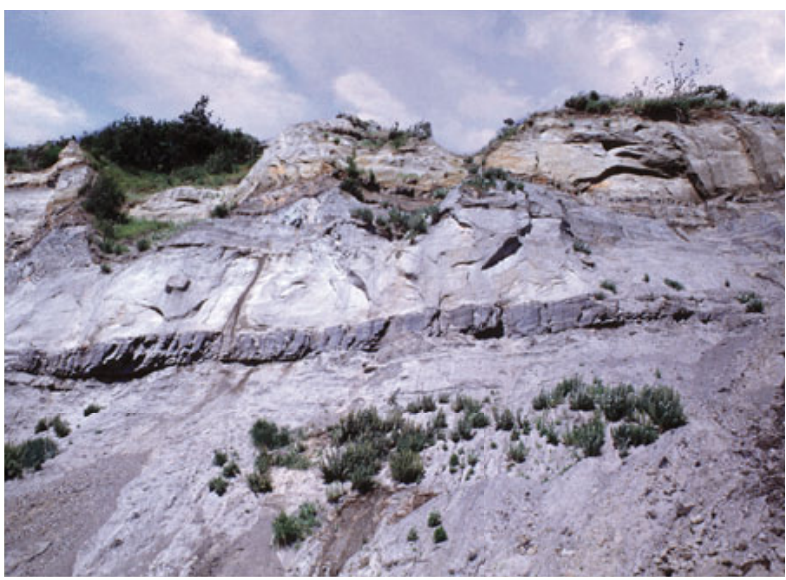

Figure 97. Photograph of a 4-foot-thick (1.2 meters) coal bed interbedded with fluvial-channel sandstones and flood plain mudstones and siltstones in the Sterling Formation in the Clam Gulch area.

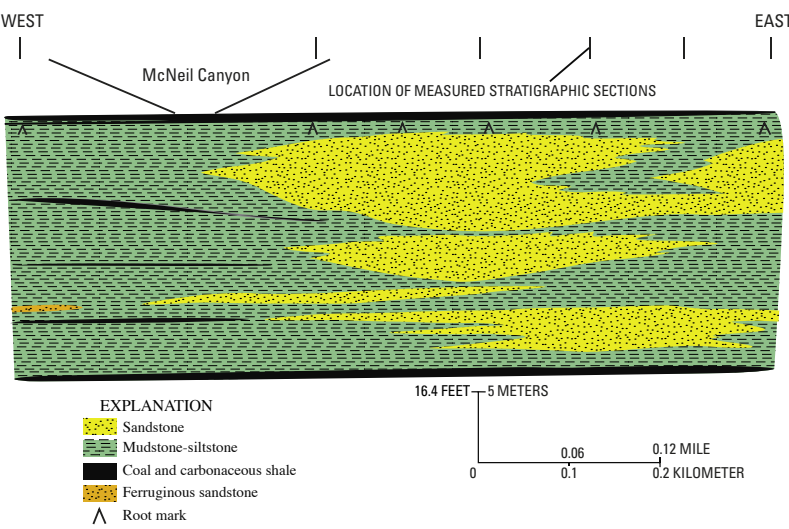

Figure 98. Stratigraphic cross section showing interbedded coal beds, fluvial-channel sandstones, and flood-plain mudstones and siltstones in the lowermost part of the Sterling Formation along the north shore of Kachemak Bay east and west of McNeil Canyon. See figure 58 for location of the cross section.

Underground mines were also opened from 1894 to 1897 west of McNeil Canyon.

Coal mining shifted to the west of Homer along the beach bluffs of the Cook Inlet from 1899 to 1951. The Cook Inlet Coal Fields Company developed the Cooper coal bed from five mine shafts in the beach bluff on Bidarki Creek, about a mile $(1.6 \mathrm{~km})$ west of Homer. The 1899-1902 total coal production from these mines was only a few hundred short tons. In 1915, Bluff Point (see fig. 58) underground mine was opened near Bidarki Creek and produced about 1,400 short tons (1,270 metric tons). Barnes (1967a) reported production from this mine to be about 1,200 short tons (1,090 metric tons) in $1921,2,700$ short tons $(2,450$ metric tons) in 1922, and 700 short tons (635 metric tons) in 1923. No production records were found for 1924 to 1945. In 1946, the Bluff Point mine was taken over by Homer Coal Corporation, which blocked out reserves of stripping coal. No reported production was recorded from this operation, which operated until 1951. Total production in the Homer coalfield is at least a few thousand tons.

\section{Coal Resource Assessment in the Southern Alaska-Cook Inlet Coal Province}

The coal resource assessments of various workers in the Southern Alaska-Cook Inlet coal province vary in magnitude and coal resource categories, which resulted in different estimates. We reconstructed these diverse coal resource estimates following guidelines of the coal-resource classification system of Wood and others (1983). This new reporting system of the coal resources of the Southern Alaska-Cook Inlet coal province modified from previous estimates is summarized in table 1. Following is a historical account of the variable coal resource assessments in the coal province.

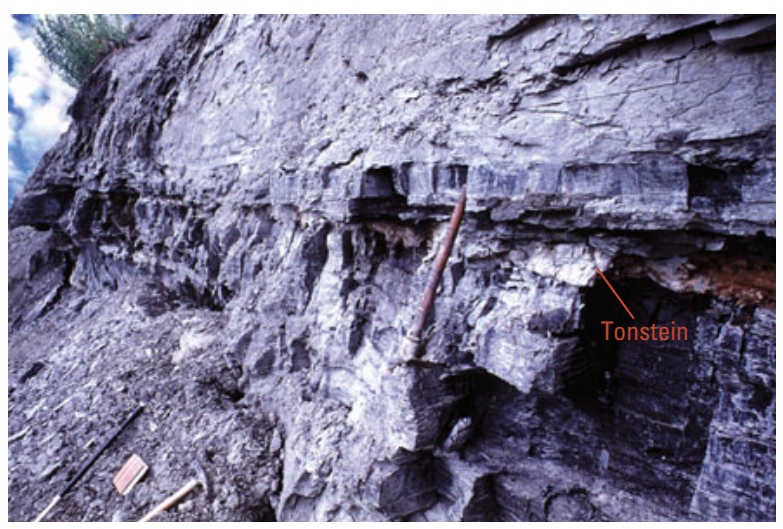

Figure 99. Photograph of a coal bed with tonstein partings and related rocks of the Beluga Formation along the beach bluffs on the northern shore of the Kachemak Bay. Mattock is 2 feet ( 0.6 meter) long for scale.

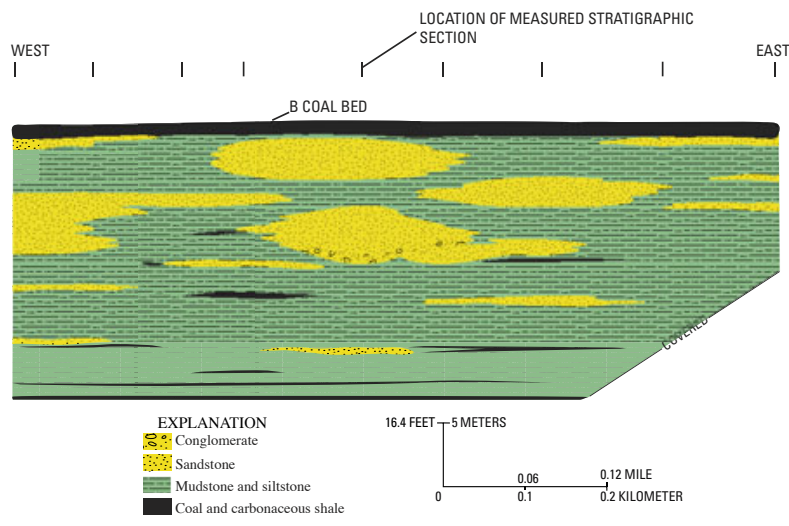

Figure 100. Stratigraphic cross section showing interbedded coal beds, fluvial-channel sandstones, and flood-plain mudstones and siltstones in the uppermost part of the Beluga Formation west of McNeil Canyon. See figure 58 for location of the cross section. 


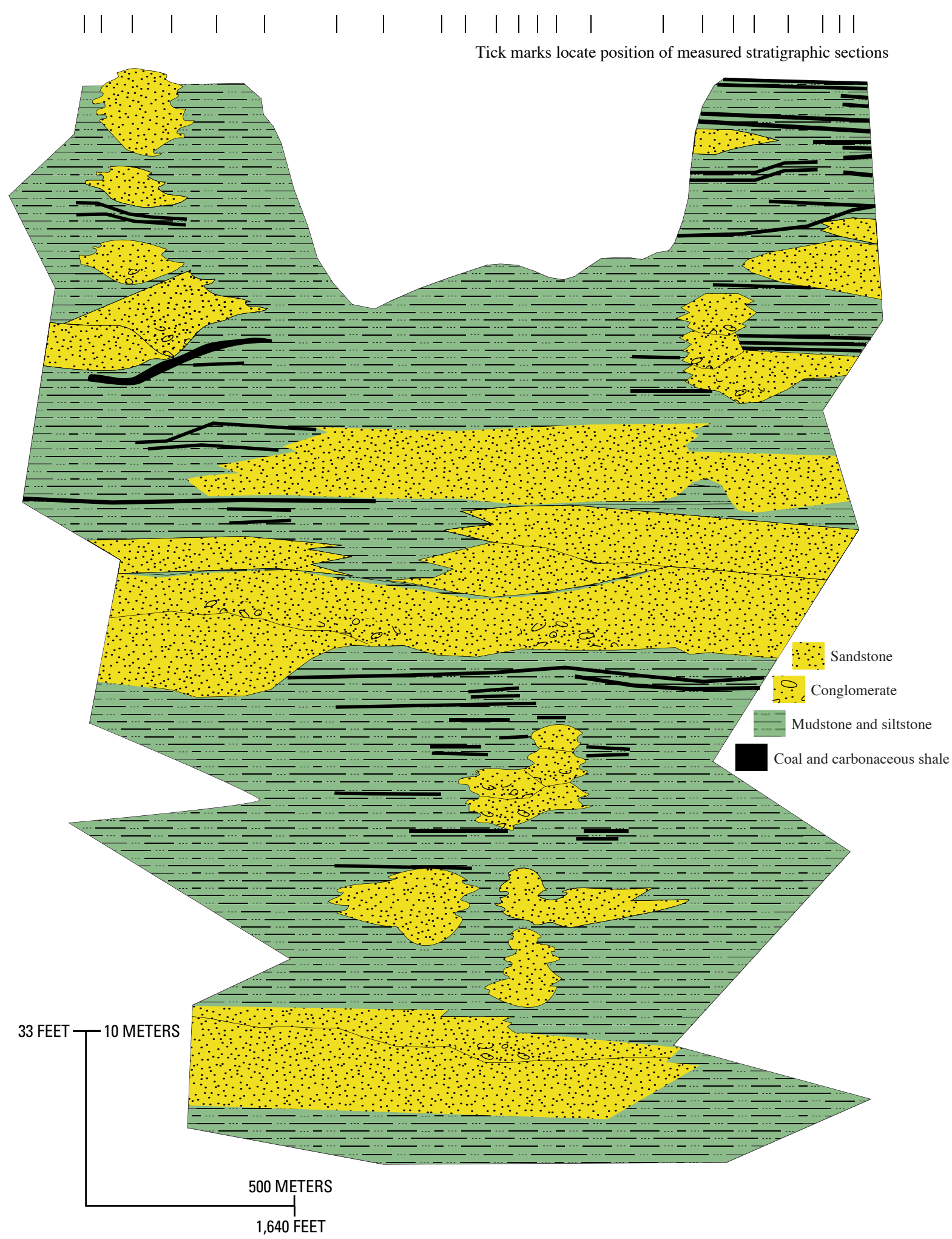

Figure 101. Stratigraphic cross section showing interbedded coal beds, fluvial-channel sandstones, and flood plain mudstones and siltstones in the uppermost part of the Beluga Formation at the mouth of Fritz Creek. See figure 58 for location of the cross section. 
Barnes (1967a) estimated identified coal resources in the Southern Alaska-Cook Inlet coal province to be about 2,910 million short tons (2,640 million metric tons). Later, McGee and Emmel (written commun., 1979) estimated the identified coal resources to be about 34,320 million short tons $(31,130$ million metric tons).

\section{Matanuska Coalfield}

Estimates of coal resources produced by various workers for the Matanuska coalfield were reported by Merritt and Belowich (1984) as being as high as $200 \times 10^{6}$ short tons $(181 \times 106$ metric tons) for measured to inferred coal resources and as high as $2.4 \times 10^{9}$ short tons $\left(2.2 \times 10^{9}\right.$ metric tons) for hypothetical coal resources. The most reliable coalresource estimates are from Barnes (1967a), who reported $137 \times 10^{6}$ short tons $\left(125 \times 10^{6}\right.$ metric tons $)$ of combined measured, indicated, and inferred coal resources, and from Merritt and Belowich (1984) who reported $24 \times 10^{9}$ short tons $\left(22 \times 10^{9}\right.$ metric tons) of hypothetical coal resources (table 6).

In the Wishbone Hill coal district, Barnes (1967a) reported total coal resources of 112 million short tons (101 million metric tons), based on apparent rank of bituminous coal with thicknesses greater than 14 inches $(35 \mathrm{~cm})$, and between 0 and 2,000 ft $(0-610 \mathrm{~m})$ of overburden. Total resources were divided into 6.6 million short tons (6.0 million metric tons) measured coal resources, 51.7 million short tons (47 million metric tons) indicated coal resources, and 53.7 million short tons (49 million metric tons) inferred coal resources.

In the Chickaloon-Castle Mountain coal district, Barnes (1967a), reported total coal resources of 25 million short tons (23 million metric tons), based on apparent rank of bituminous coal, with thicknesses greater than 14 inches (35 $\mathrm{cm})$, and between 0 and 2,000 ft (0-610 m) of overburden. Total resources were divided into 0.0 measured coal resources, 0.7 million short tons ( 0.6 million metric tons) indicated coal resources, and 24.3 million short tons (22 million metric tons) inferred coal resources.

In the Anthracite Ridge coal district, the only identified minable bed of anthracite, 4.2-6.6 ft (1.3-2.0 m) thick, underlies an area of no more than 2.5 acres ( 1 hectare) and totals no more than 22,000 short tons (20,000 metric tons)

(Waring, 1936; Merritt and Belowich, 1984). One other reported anthracite occurrence (Merritt and Belowich, 1984), too thin to be mined, is on a large active landslide (Detterman and others, 1976).

\section{Susitna-Beluga Coalfield}

Barnes (1967a) reported identified coal resources of the Susitna-Beluga coalfield as 2.4 billion short tons (2.2 billion metric tons) (table 6). Total resources were estimated for subbituminous coal beds greater than $2.5 \mathrm{ft}$
$(0.76 \mathrm{~m})$, with overburden to $1,000 \mathrm{ft}(0-305 \mathrm{~m})$ in the drainage basins of the Yentna, Skwentna, Beluga, and Chuitna Rivers, the Capps Glacier coal district, and an area southwest of Tyonek. Indicated coal resources are 56 million short tons (51 million metric tons) in the Yentna River Basin, 123 million short tons (116 million metric tons) in the Skwentna River Basin, 260 million short tons (236 million metric tons) in the Beluga River Basin, 1.54 billion short tons (1.4 billion metric tons) in the Chuitna River Basin, 406 million short tons (368 billion metric tons) in the Capps Glacier district, and 9.4 million short tons ( 8.5 million metric tons) southwest of Tyonek.

Wahrhaftig and others (1994), based on Barnes' 1966 report, calculated indicated coal resources of (1) $4.5 \times 10^{6}$ short tons $\left(4.1 \times 10^{6}\right.$ metric tons $)$ in beds less than $6.5 \mathrm{ft}(2 \mathrm{~m})$ thick in the Peters Hills; (2) about $44 \times 10^{6}$ short tons $\left(40 \times 10^{6}\right.$ metric tons) of coal mainly in beds more than $10 \mathrm{ft}(3 \mathrm{~m})$ thick in the Fairview Mountain area; (3) $20 \times 10^{6}$ short tons $\left(18 \times 10^{6}\right.$ metric tons $)$ of coal mainly in beds more than $6.5 \mathrm{ft}(2 \mathrm{~m})$ thick in the Johnson Creek area; and (4) $110 \times 10^{6}$ short tons $\left(100 \times 10^{6}\right.$ metric tons $)$ of coal in the downfaulted half graben along Canyon Creek area. A drilling program by Mobil Oil Corporation resulted in estimates of $500 \times 10^{6}$ short tons $\left(450 \times 10^{6}\right.$ metric tons $)$ of coal within $250 \mathrm{ft}(76 \mathrm{~m})$ of the surface in beds 10 to $50 \mathrm{ft}$ ( 3 to $15 \mathrm{~m}$ ) thick, in two leased areas totaling 23,000 acres (9,300 hectares). One area includes the Canyon Creek drainage basin and the other extends from the Skwentna River northward across Johnson Creek (Blumer, 1981).

\begin{tabular}{|c|c|c|c|}
\hline Coal field & Source & Classification & $\begin{array}{c}\text { Coal } \\
\text { Resource } \\
\text { estimate }\end{array}$ \\
\hline \multirow{4}{*}{ All Southern Alaska-Cook Inlet } & Barnes (1967a) & Identified $^{1}$ & 2,910 \\
\hline & McGee, D.L., and Emmel, K.S ${ }^{2}$ & Identified & 34,320 \\
\hline & Merritt and Hawley (1986) & Identified & 11,600 \\
\hline & Merritt and Hawley (1986) & Hypothetical & $1,570,000$ \\
\hline \multirow{4}{*}{ Matanuska } & Barnes (1967a) & Identified $^{3}$ & 137 \\
\hline & Barnes (1967a) & Hypothetical & 274 \\
\hline & Merritt and Belowich (1984) & Identified & 200 \\
\hline & Merritt and Belowich (1984) & Hypothetical & 24,000 \\
\hline \multirow{3}{*}{ Susitna-Beluga } & Barnes (1967a) & Identified $^{4}$ & 2,400 \\
\hline & Merritt and Hawley (1986) & Identified & 11,100 \\
\hline & Merritt and Hawley (1986) & Hypothetical & 34,800 \\
\hline \multirow{6}{*}{ Broad Pass } & Hopkins (1951) & Identified & 13 \\
\hline & Barnes (1967a) & Identified $^{3}$ & 64 \\
\hline & Merritt and Hawley (1986) & Identified & 50 \\
\hline & Merritt and Hawley (1986) & Hypothetical & 500 \\
\hline & Wahrhaftig and others (1994) & Identified & 0.3 \\
\hline & Wahrhaftig and others (1994) & Hypothetical & 13 \\
\hline \multirow{2}{*}{ Kenai } & Barnes and Cobb (1959) & Indicated $^{4}$ & 400 \\
\hline & Barnes (1967a) & Identified $^{4}$ & 318 \\
\hline \multirow{4}{*}{ Kenai (onshore) } & McGee, D.L., and Emmel, K.S ${ }^{2}$ & Identified & 318 \\
\hline & Merritt and Hawley (1986) & Identified & 320 \\
\hline & Merritt and Hawley (1986) & Hypothetical & 35,000 \\
\hline & McGee, D.L., and Emmel, K.S ${ }^{2}$ & Hypothetical & 34,000 \\
\hline \multirow{2}{*}{ Kenai (offshore) } & McGee, D.L., and Emmel, K.S ${ }^{2}$ & Hypothetical & 100,000 \\
\hline & Merritt and Hawley (1986) & Hypothetical & $1,500,000$ \\
\hline \multicolumn{4}{|c|}{$\begin{array}{l}{ }^{1} \text { Reported resource estimates with overburden classifications of } 0-1,000 \text { feet, } 1,000-2,000 \text { feet, and } \\
2,000-3,000 \text { feet. }\end{array}$} \\
\hline \multicolumn{4}{|c|}{$\begin{array}{l}{ }^{2} \text { McGee, D.L., and Emmel, K.S., 1979, unpublished report, Alaska Division of Geological and } \\
\text { Geophysical Surveys, Fairbanks, Alaska. }\end{array}$} \\
\hline \multicolumn{4}{|c|}{${ }^{3}$ Reported resource estimates with overburden classifications of $0-2,000$ feet. } \\
\hline
\end{tabular}




\section{Broad Pass Coalfield}

The hypothetical and identified coal resources of the Broad Pass coalfield reported by Wahrhaftig and others (1994) were $13.3 \times 10^{6}$ short tons $\left(12 \times 10^{3}\right.$ metric tons $)$ of coal combined for two beds with a maximum thickness of $10 \mathrm{ft}$ ( $3 \mathrm{~m})$. According to Barnes (1967a), $64 \times 10^{3}$ short tons $\left(58 \times 10^{3}\right.$ metric tons) of coal was mined from 1940 to 1954 , and the rest was unminable (table 6).

Hopkins (1951) estimated that at least $13 \times 10^{6}$ short tons $\left(12.2 \times 10^{6}\right.$ metric tons) of coal exist beneath the area of known exposures of Tertiary rocks at Broad Pass Station, but only $300 \times 10^{3}$ short tons $\left(270 \times 10^{3}\right.$ metric tons $)$ of lignite with an ash yield of 8-25 percent was actually measured.

Barnes (1967a) reported total coal resources of the Broad Pass coalfield as 64 million short tons (58 million metric tons). Based on coal-bed thickness of $2.5 \mathrm{ft}(0.75 \mathrm{~m})$ for subbituminous rank and overburden of 0-1,000 ft (0-305 m), Broad Pass Station area contains as much as 0.3 million short tons (0.27 million metric tons) indicated coal resources, 63.3 million short tons (57 million metric tons) inferred coal resources, or a total coal resource of 63.6 million short tons (57.4 million metric tons). Costello Creek area contains 0.3 million short tons ( 0.27 million metric tons) indicated coal resources.

\section{Kenai Coalfield}

Coal resources of the Kenai coalfield are mainly concentrated in the Homer coal district. Barnes and Cobb (1959) calculated indicated coal resources of $400 \times 10^{6}$ short tons $\left(360 \times 10^{6}\right.$ metric tons) for coal beds greater than $2 \mathrm{ft}$ $(0.6 \mathrm{~m})$ thick, of which $50 \times 10^{6}$ short tons $\left(45 \times 10^{6}\right.$ metric tons) are in beds more than $5 \mathrm{ft}(1.5 \mathrm{~m})$ thick. These coal beds are covered by $<990 \mathrm{ft}(300 \mathrm{~m})$ of overburden. Barnes and Cobb's investigation indicated that all except the extreme northern and northeastern parts of the Homer coal district, about $750-\mathrm{mi}^{2}\left(1,940-\mathrm{km}^{2}\right)$ area, is underlain by coal beds greater than $2 \mathrm{ft}(0.6 \mathrm{~m})$ thick. Thus, the potential coal resources of the Homer coal district may be several billion short tons. Barnes (1967a) reported the total coal resources of the Homer coal district to be more than 318 million short tons (290 million metric tons). McGee and Emmel (written commun., 1979) reported Kenai coalfield onshore resources as 0.2 million short tons ( 0.18 million metric tons) measured coal resources, 318 million short tons ( 290 million metric tons) identified coal resources, and 34 billion short tons (31 billion metric tons) hypothetical resources (table 6).

Based on geophysical logs from drill holes throughout the Cook Inlet Basin, McGee and O'Connor (1975) calculated a hypothetical resource of $1.2 \times 10^{12}$ short tons $\left(1.1 \times 10^{12}\right.$ metric tons $)$ of coal of apparent lignite rank to a depth of $10,000 \mathrm{ft}(3,048 \mathrm{~m})$ and $110 \times 10^{9}$ short tons $\left(100 \times 10^{9}\right.$ metric tons) to a depth of $2,000 \mathrm{ft}(610 \mathrm{~m})$. McGee and Emmel (written commun., 1979) reported about 34.32 billion short tons ( 31 billion metric tons) of hypothetical coal resources in the offshore Cook Inlet Basin. Affolter and Stricker (1987b) estimated a hypothetical resource of $0.8 \times 10^{12}$ short tons $\left(0.7 \times 10^{12}\right.$ metric tons $)$ of the Kenai Group coal to lie beneath the waters of Cook Inlet.

\section{Coal Quality}

Coal in the Southern Alaska-Cook Inlet coal province ranges from lignite to anthracite (table 7). The lignite with heat values of $5,410-8,020 \mathrm{Btu} / \mathrm{lb}(3,010-4,460 \mathrm{kcal} / \mathrm{kg})$ and subbituminous coal with heat values of $8,060-9,520 \mathrm{Btu} / \mathrm{lb}$ $(4,480-5,290 \mathrm{kcal} / \mathrm{kg})$ are mainly in the Broad Pass, SusitnaBeluga, and Kenai coalfields (Barnes, 1967a). Bituminous coal with heat values of 10,390-14,380 Btu/lb (5,770-7,990 $\mathrm{kcal} / \mathrm{kg}$ ) and semianthracite with heat values of $10,720-13,420$ $\mathrm{Btu} / \mathrm{lb}(5,960-7,460 \mathrm{kcal} / \mathrm{kg})$ coal are mainly in the Matanuska coalfield (Barnes, 1967a).

In the Matanuska coalfield, the ash yield varies from 2.4 to 21.7 percent, sulfur from 0.2 to 1.0 percent, and moisture content from 1.1 to 20.3 percent (as-received basis; Barnes, 1967a). Run-of-the-mine coal quality in the Wishbone Hill coal district varies from 9 to 29 percent ash, 0.3 to 0.4 percent sulfur, and 4.0 to 6.0 percent moisture content (as-received basis; Germer, 1986; Belowich, 1994).

In the Susitna-Beluga coalfield, coal varies from 2.1 to 30.5 percent ash yield, 0.1 to 0.3 percent sulfur, and 11.3 to 33.1 percent moisture contents (as-received basis; Barnes, 1967a). In the Chuitna River drainage basin, Affolter and Stricker (1994) reported ash yield that varies from 4.83 to 38.67 percent, sulfur content from 0.08 to 0.18 percent, and moisture content from 19.19 to 26.15 percent. In the Beluga River drainage basin, the ash yield varies from 3.59 to 29.87 , sulfur content from 0.08 to 0.32 , and moisture content from 16.78 to 7.49 percent. In the Capps Glacier district the coal beds contain ash yield of 9.3-40.3 percent, sulfur 0.12-0.33, and moisture 4.8-26.0 percent (as-received basis; Affolter and Stricker, 1986). Flores and others (1994) suggested that the higher sulfur content in coal beds in the Chuitna River drainage basin was influenced by tidal incursions into mires.

In the Broad Pass coalfield, the ash yield varies from 6.0 to 21.2 percent, sulfur from 0.2 to 0.6 percent, and moisture content from 8.7 to 35.8 percent (as-received basis; Barnes, 1967a).

In the Kenai coalfield, with emphasis on the coal beds in the Homer coal district, ash yield varies from 3.8 to 22.0 percent, sulfur content from 0.1 to 0.4 percent, and moisture content from 16.5 to 30.4 percent (Barnes and Cobb, 1959; Barnes, 1967a). Affolter and Stricker (1994) reported ash yield ranging from 4.80 to 26.90 percent, sulfur content from 0.20 to 
1.30 percent, and 11.0 to 26.50 percent moisture content from the Kenai coalfield.

\section{Coal Petrology}

The coal petrology of the Tyonek coal beds in the Chuitna River drainage area was investigated by Rao and Smith (1986). Vitrinite (or huminite) is the most abundant maceral and varies from about 66 to 92 percent. Minor liptinite varies from 4 to 18 percent and inertinite from 0 to 9 percent. The woody or huminite maceral is composed mainly of cypress trees (Rao and Smith, 1986). However, oak, beech, hickory, elm, walnut, alder, and birch trees are represented in the peatforming mires. The huminite maceral is either unevenly distributed vertically throughout the coal beds or it increases in the upper and lower parts of the coal beds. Liptinite macerals in some coal beds increases in the upper part of the coal beds. Inertinite appears to be less preferentially distributed vertically in the coal beds than the huminite and liptinite macerals. However, local peak occurrences of inertinite indicate generation of fusinite or charcoal that is formed by forest fires during dry periods. High occurrence of liptinite suggests differential decomposition of the more resistant exinite from vegetal matter. The high concentration of huminite in the lower part of coal beds indicates that the mires were initially vegetated by abundant trees, which evolved into less woody vegetation through time. The high concentration of huminite in the upper part indicates that the mire supported more woody vegetation through time.

\section{Coalbed Methane Potential}

The coal resources of Alaska (about 5,526 billion short tons; see table 1) contain significant potential economic coalbed methane resources. Methane derived from coal, which has migrated and is stored in interbedded sandstone reservoirs in the Cook Inlet Basin, is presently being developed. Coalbed gas or methane-rich gas is stored (adsorbed) in the coal along fractures, cleats, and pores and (or) within (absorbed) the molecular structure of the coal. Gas is stored in the coal by molecular attraction on the surfaces of the structures of the coal. Methane is a by-product of fermentation during deposition and coalification during burial of peat. The ability of the coal to store gas is a function of rank or grade of coalification (for example, lignite, subbituminous, bituminous) and temperature and pressure. Generally, more methane is stored in higher rank coal and at high pressure whereas higher temperature decreases storage capacity. Methane generated in higher rank coal (for example, bituminous) is thermogenic in origin, and methane produced in lower rank coal (lignite and subbituminous) is biogenic in origin. Biogenic gas is generated during bacterial activity by methanogens or anaerobes that produced methane as a by-product of their metabolism. In most cases methanogens do this by reducing carbon dioxide with hydrogen to produce methane. Biogenic gas generated from lignites in Alaska was determined from a 1994 U.S. Geological Survey test well in the Yukon Basin (Flats), where the coal beds are more than $21 \mathrm{ft}(6.4 \mathrm{~m})$ thick.

A major by-product of development of coalbed methane, especially for subbituminous coal, is coproduced water. Volumes of water produced in major methane-producing

Table 7. Range (minimum and maximum values) of quality parameters for Tertiary coal deposits in the Matanuska, Broad Pass, Susitna, and Kenai coalfields in the Southern Alaska-Cook Inlet coal province.

[All analyses except Calorific value (Btu) are in percent. Values reported on an asreceived basis. Modified from Merritt, 1984]

\begin{tabular}{lcccccc}
\multicolumn{1}{c}{ Area } & Moisture & $\begin{array}{c}\text { Volatile } \\
\text { matter }\end{array}$ & $\begin{array}{c}\text { Fixed } \\
\text { carbon }\end{array}$ & $\begin{array}{c}\text { Ash } \\
\text { yield }\end{array}$ & $\begin{array}{c}\text { Total } \\
\text { sulfur }\end{array}$ & $\begin{array}{c}\text { Calorific } \\
\text { value } \\
\text { Btu per } \\
\text { pound }\end{array}$ \\
\hline Broad Pass & $20-35$ & $27-35$ & $20-28$ & $10-20$ & $0.2-0.4$ & $5,500-7,100$ \\
Kenai & $20-27$ & $30-38$ & $25-35$ & $3-25$ & $0.2-0.4$ & $6,500-8,500$ \\
Matanuska Valley & & & & & & \\
$\quad$ Wishbone Hill & $3-9$ & $32-45$ & $38-51$ & $4-22$ & $0.2-1.0$ & $10,400-13,200$ \\
Chickaloon & $1-5$ & $14-24$ & $60-72$ & $5-20$ & $0.4-0.7$ & $11,960-14,400$ \\
Anthracite Ridge & $3-9$ & $7-11$ & $65-81$ & $7-20$ & $0.2-0.7$ & $10,720-14,000$ \\
Susitna Lowland & $10-30$ & $28-40$ & $25-45$ & $3-30$ & $0.1-0.7$ & $6,200-9,500$ \\
\hline
\end{tabular}


basins in the conterminous United States vary significantly between bituminous and subbituminous coal. The volume of coproduced water from bituminous coal ranges in average from 48 to 240 barrels (7,632 to 38,160 liters) of water per day per well and from the subbituminous coal the average is about 440 barrels (91,600 liters) (Flores, 2000). Hence, the water: gas ratio for the bituminous coal ranges from 0.029 to 0.51 barrel per thousand cubic feet (16.3 to 286 liters per $100 \mathrm{~m}^{3}$ ) and from the subbituminous coal is 2.88 barrels per thousand cubic feet $\left(21,360\right.$ liters per $\left.100 \mathrm{~m}^{3}\right)$ (Flores, 2000). In order to produce the methane from the coal, the reservoir needs to be dewatered, which results in the depressurization of the reservoir. This water can be disposed of either on the surface, into ponds or existing drainages, or reinjected below the surface. Regulations, quality, and amount of the coproduced water influence the choice of a disposal system. Coproduced water from subbituminous coal of the Tertiary Fort Union Formation being developed in the Powder River Basin of Wyoming is freshwater. It contains concentrations of dissolved solids mainly of bicarbonate, and trace elements and $\mathrm{pH}$ values that are generally below and within recommended drinking-water standards (Flores, 2000). Thus gas operators in that basin are permitted to dispose of the coproduced water on the surface; however, the large volume of water being disposed of is affecting the environment (for example, biota, ephemeral drainages, ground-water supply). Water-disposal problems may influence potential development in Alaska where the permafrost (for example, Northern Alaska-Slope coal province) is thick (Ferrians, 1965), and freezing temperatures at the surface for much of the year may curtail surficial disposal by ponding or along preexisting drainages. The quality of water such as concentration of total dissolved solids and location of coalbed gas production where recharge areas are juxtaposed to brackishmarine bodies of water (sea, ocean, bay) may prevent surface disposal or reinjection, which may contaminate ground-water supply.

Smith (1995) reported that Alaska's in-place coalbed methane resources might be as much as 1,000 trillion cubic feet (tcf) (28 trillion cubic meters [tcm]) based on estimates of the gas content of as much as 245 standard cubic feet per ton (scf/t) for the coals. The high coalbed-methane resource estimate of Smith (1995) utilized $200 \mathrm{scf} / \mathrm{t}$ for both the subbituminous and bituminous coals in the Northern Alaska-North Slope coal province and $152 \mathrm{scf} / \mathrm{t}$ for the subbituminous coal in the offshore area in the Southern Alaska-Cook Inlet coal province. Our investigations of the subbituminous coals in the Powder River coals indicate gas content ranging from 0 to $99 \mathrm{scf} / \mathrm{t}$, averaging $25 \mathrm{scf} / \mathrm{t}$ (Stricker and others, 2001). If the Powder River Basin coalbed-methane content is applied for the Alaska subbituminous coal, Smith's estimate will be reduced to about one-half the volume.

\section{Northern Alaska-Slope Coal Province}

The voluminous lignite, subbituminous, and bituminous coal of the Northern Alaska-Slope coal province indicates a high potential for large biogenic and thermogenic gas resources. The abundance of bituminous coal with 1,910 billion short tons (1,732 billion metric tons) and subbituminous coal with 1,960 billion short tons (1,778 trillion metric tons) in the Northern Alaska-Slope coal province (fig. 102) indicates a high potential for thermogenic and biogenic methane resources. Outcrop and surface-projected mean vitrinite reflectance values in the Northern Alaska-Slope coal province range from 0.31 to 1.71 percent, which corresponds to lignite to low volatile bituminous coal ranks (figs. 103 and 104; table $8 \mathrm{a}$ and $8 \mathrm{~b}$ ). Coal rank generally increases southward toward the Brooks Range where the vitrinite reflectance values exceed 1.71 percent (see table $8 \mathrm{a}$ and $8 \mathrm{~b}$ ). Thus, the vitrinite reflectance values suggest a range of coal maturation in which coalbed methane, both biogenic and thermogenic, may be generated from subbituminous and bituminous coals, respectively.

Tyler and others (2000) and Clough and others (2000) evaluated the potential coalbed methane for the rural communities in the Northern Alaska-Slope coal province. They suggested that based on depth, coal thickness, and depositional systems, primary coalbed methane targets and potential exploration fairways occur mainly in the Cretaceous Nanushuk Group. These workers identified the area between the eastern boundary of the National Petroleum Reserve of Alaska (NPRA) to Chukchi Sea (see figs. 8 and 10) as containing the highest coalbed methane potential because of the thickest net coal, which is $>300 \mathrm{ft}(91 \mathrm{~m})$ (see fig. 8). Potential methane development in this area may be from most of the coal beds that lie at an average depth of 2,000 ft $(610 \mathrm{~m})$.

Drilling depths for coalbed methane are recommended below the permafrost zone, which is as much as 2,000 ft deep $(610 \mathrm{~m})$ (Ferrians, 1965), to $6,000 \mathrm{ft}(1,830 \mathrm{~m})$. McKee and others (1986) suggested that permeability is very low below the 6,000-ft $(1,825-\mathrm{m})$ threshold. The Meade Test Well No. 1 and Kaolak Test Well No. 1 have related gas shows with coal beds as much as $30 \mathrm{ft}(9.1 \mathrm{~m})$ thick as well as interbedded sandstones at depths between 1,240 and 2,200 ft (378 and $670 \mathrm{~m}$ ) (Collins, 1959). Here, Barnes (1967a) reported that there are as many as 60 coal beds with a net coal thickness of $350 \mathrm{ft}(107 \mathrm{~m})$ within a 4,600-ft $(1,400-\mathrm{m})$ interval. Methane gas shows associated with coal beds in the Nanushuk Group and Corwin Formation were recorded at depths between the surface to about 1,420 ft (430 m) by Husky Oil NPR, Operations, Inc. (1982-83). The presence of high gas content in subbituminous coal beds in the Nanushuk and Colville Groups in the NPRA was also reported by Claypool and Magoon (1988). These investigators also noted that the shallow, immature nature of the coal beds make for an unfavorable thermogenic gas source. However, similar subbituminous coal beds of the Fort Union Formation in the Powder River Basin of Wyoming are currently producing coalbed gas from depths of 250$1,500 \mathrm{ft}(76-460 \mathrm{~m})$. 
The vitrinite reflectance values of the Cretaceous coalbearing rocks (Corwin-Chandler, Grandstand, Torok Formations, the Pebble shale unit, and underlying Jurassic-Devonian rocks) in the Northern Alaska-Slope coal province are shown in figures 105 and 106. The vitrinite reflectance values down to $6,000 \mathrm{ft}(1,830 \mathrm{~m})$ range from about 0.30 to 0.66 percent, which corresponds mainly to lignite to subbituminous coal through subordinate high-volatile bituminous $\mathrm{C}$ coal (Stach and others, 1982). Vitrinite reflectance values are superimposed on the cross section of the Nanushuk Group and underlying rocks (fig. 107). Here, the vitrinite reflectance values of the coal-bearing Corwin-Chandler Formations range from $<0.5$ to $>0.7$ percent in the western part (updip) of the Northern Alaska-Slope coal province and from $<0.5$ to $<0.6$ percent in the eastern part (downdip). This indicates that the coal beds may have generated mixed biogenic and thermogenic methane in the western part of the coal province and mainly biogenic methane in the eastern part. The extent of Nanushuk coal beds and the high-potential coalbed methane resources in the western part of the Northern Alaska-Slope coal province is shown in figures 108 and 109. In figure 108, the depths to the vitrinite reflectance value of 0.6 percent are superimposed on the base of Nanushuk Group and the net coal thickness of the Nanushuk Group. When the vitrinite reflectance contours are merged with the extent of the Nanushuk coal and where the Nanushuk coal beds have a net thickness of $>400 \mathrm{ft}(192 \mathrm{~m})$, the area of highest coalbed methane potential is in the southwestern part of the Northern Alaska-Slope coal province.

Callahan (1979) suggested that the North Slope gas is biogenic and generated by a microbial activity. Carbon isotopic analyses of near-surface $(0-4,920 \mathrm{ft}, 0-1,500 \mathrm{~m})$ gashydrate- and coal-bearing units by Collett (1993) yielded carbon isotopic values averaging about -49 permil. This indicates that the methane in near-surface strata is from mixed biogenic and thermogenic origin. However, based on vitrinite reflectance values (0.30-0.66), the gas-hydrate and coal-bearing rocks probably were not subjected to high temperatures; thus, the thermogenic gas may have migrated from greater depths.

Tyler and others (2000) suggested that in addition to targeting coal beds for conventional methane exploration, stratigraphic and structural traps should be explored for coalbed methane potential. Conventional play for thermogenic gas in the coal that migrated updip and was trapped below the permafrost was also recommended for exploration. The permafrost zone serves as a seal for trapping migrating gas. Stratigraphic traps were suggested by Tyler and others (2000) where coal beds pinch out updip behind progradational shoreline sequences (for example, delta-front, barrier-shoreface sandstones) in the Nanushuk Group. Structural traps may be found in fault-cored anticlines (for example, Meade and Wainwright arches) (see fig. 8; Tyler and others, 2000).

\section{Central Alaska-Nenana Coal Province}

The coalbed methane potential for the Central AlaskaNenana coal province is not as high as the Northern AlaskaSlope coal province. The coal beds in this coal province are mainly subbituminous, range from 50 to $66 \mathrm{ft}(15$ to $20 \mathrm{~m})$ in thickness, and occur to depths of 3,000 ft (910 m). In addition, the Healy Creek Formation is sealed by thick mudstones of the overlying Sanctuary Formation. Exploration targets for potential coalbed methane are along the axes of large synclinal basins such as the Healy Creek and Lignite Creek Basins. In these basins, most of the coal resources in the Healy Creek and Suntrana Formations are thick (as much as $65 \mathrm{ft}$ or $20 \mathrm{~m}$ thick) and found from 1,000-to 3,000-ft (305 to $914 \mathrm{~m}$ ) depths (Wahrhaftig and others, 1994).

Although the rank of the Healy Creek, Suntrana, and Lignite Creek coals is mainly subbituminous, Affolter and Stricker (1994) reported heating (calorific) values ranging from 6,130 to $9,210 \mathrm{Btu} / \mathrm{lb}(3,410$ to $5,120 \mathrm{kcal} / \mathrm{kg})$, which correspond to lignite to subbituminous coal. Outcrop and surface-projected vitrinite values of the coal-bearing Usibelli Group in the Central Alaska-Nenana coal province range from 0.21 to 0.48 percent, which corresponds to lignite to subbituminous $\mathrm{C}$ coal ranks (fig. 104). Coal ranks generally increase south-southeast toward the Alaska Range, indicating that methane generated in these mainly subbituminous coal deposits is biogenic. The rank and quality (low ash and sulfur) of the Healy Creek, Suntrana, and Lignite Creek coals beds are very similar to the subbituminous coal beds of the Fort Union Formation in the Powder River Basin of Wyoming, which are producing economic biogenic methane at an average of $25 \mathrm{scf} / \mathrm{t}$. In that basin, coalbed methane is produced as close as 1-2 miles (1.6-3.2 km) from coal strip mines (Stricker and others, 2001). However, the strip mining has liberated gas by pressure reduction. Because the Fort Union coal beds have high water saturation, depressurization from dewatering during strip mining releases and subsequently causes migration of gas by desorption and diffusion through the microstructures in the coal. Thus, success in developing the coalbed methane for the Healy Creek and Suntrana coal beds should probably be focused on areas removed from old underground coal mines and current strip mines.

\section{Southern Alaska-Cook Inlet Coal Province}

The coalbed methane potential for the Southern AlaskaCook Inlet coal province is high. This resource potential varies from the Kenai, Broad Pass, and Beluga coalfields, which contain lignite and subbituminous coal, to the Matanuska coalfield, which contains bituminous and semianthracite coals.

Magoon and Anders (1990) reported that the gas produced from the Kenai Group in the Cook Inlet is biogenic. Gas is mainly derived from the Tyonek and Beluga Formations. This gas is produced primarily from gas-driven-sandstone reservoirs (table 9) in the Tyonek, Beluga, and Sterling 


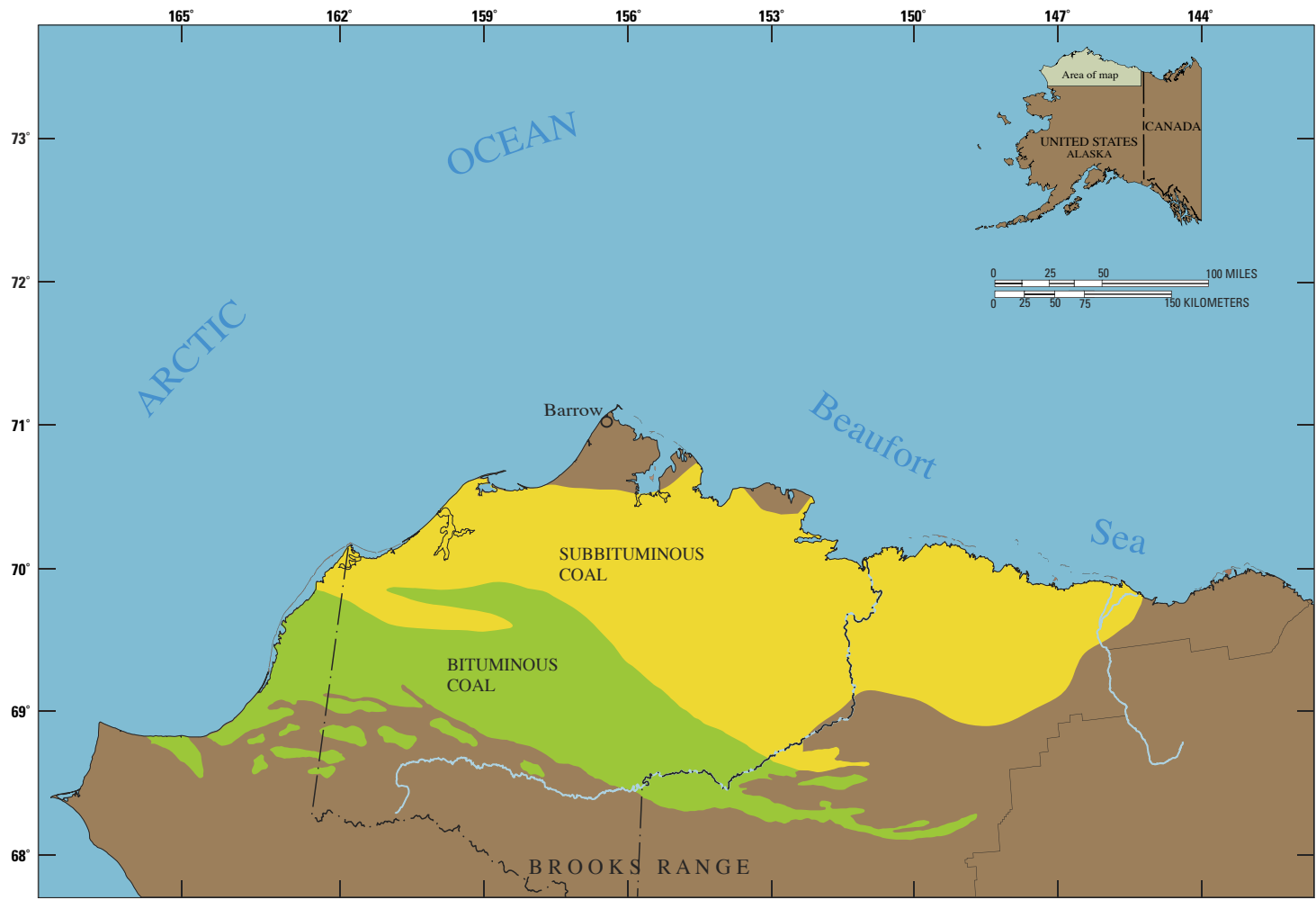

Figure 102. Map of the Northern Alaska-Slope coal province showing distribution of bituminous and subbituminous coals. Modified from Sable and Stricker (1987).

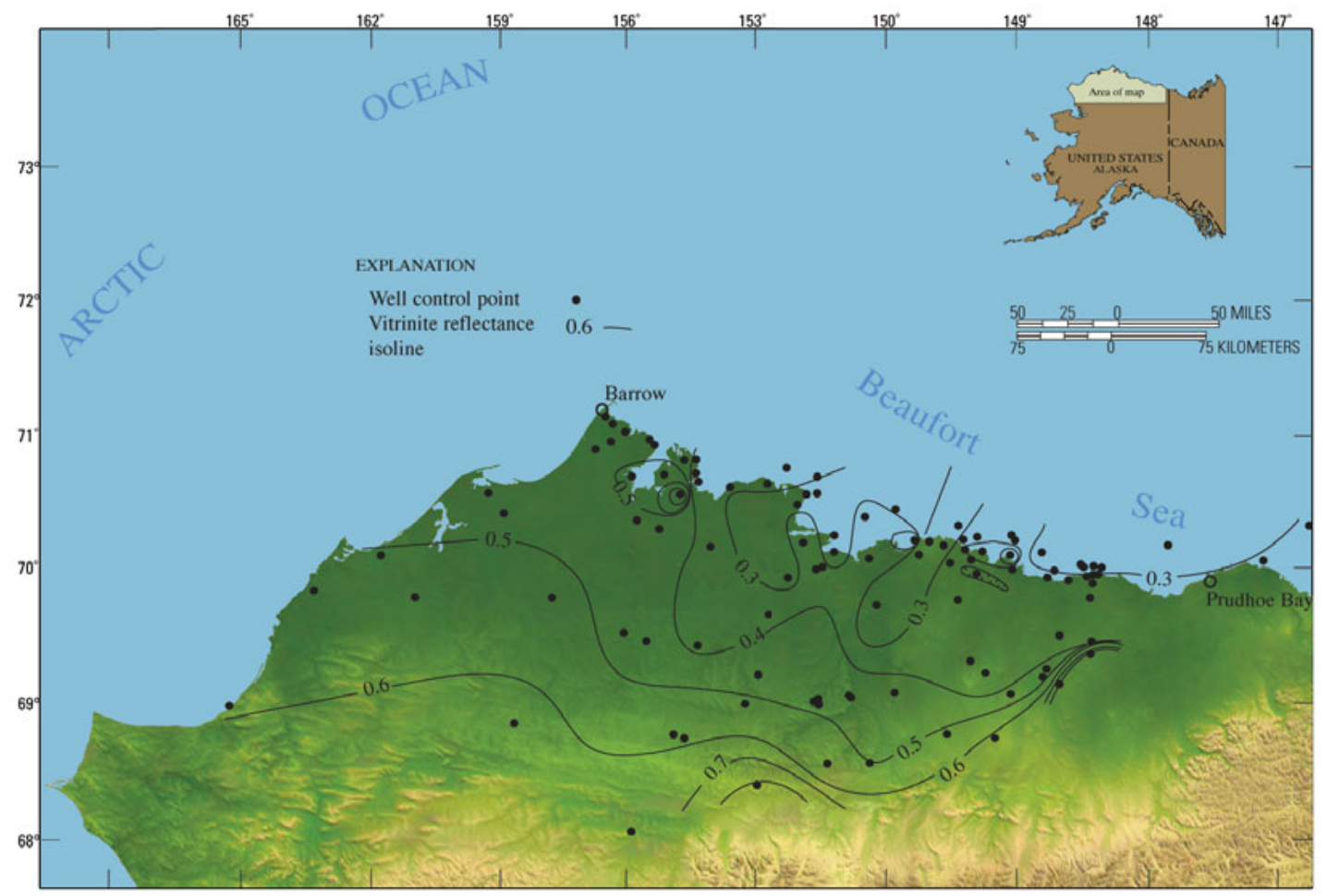

Figure 103. Distribution of surface vitrinite reflectance values at sea level in the Northern Alaska-Slope coal province. 
Formations (Brimberry and others, 1997; Flores and others, 1998). Figure 110 shows the distribution of gas and oil fields in the Cook Inlet Basin producing mainly from the Tyonek, Beluga, and Sterling sandstones. Figures 111 and 112 show the vertical distribution and occurrence of gas in the Sterling and Beluga sandstone reservoirs; gas accumulations in associated coal beds in the Kenai field are shown in figure 113 (Brimberry and others, 1997; Flores and others, 1998). Since 1958, when gas production from the Cook Inlet was first recorded by the Alaska Department of Natural Resources, Division of Oil and Gas (1997), the total (gross) production from these sandstone reservoirs was about 7,993 billion cubic feet. This gas is thought to be derived from the Tyonek, Beluga, and Sterling coal beds (Kelly, 1968). Coal mines in the Matanuska coalfield have emitted methane from the Chikaloon coal beds, which has caused several mine explosions in 1937 and 1957 (Barnes and Payne, 1956; Smith, 1995).

Thirteen out of 18 coal beds in the Tyonek Formation in the upper Cook Inlet Basin (northwest of Wasilla) were determined to contain coalbed methane by Smith (1995). Gas content ranges from $63 \mathrm{ft}^{3}$ per short ton $\left(1.97 \mathrm{scm}^{3} / \mathrm{gm}\right)$ at standard temperature and pressure (STP) for coal beds at a shallow depth of $500 \mathrm{ft}(152 \mathrm{~m})$ to $245 \mathrm{ft}^{3}$ per short ton $\left(7.6 \mathrm{scm}^{3} / \mathrm{gm}\right)$ at STP for coal beds at a depth of 1,200 ft (366 m). Vitrinite reflectance values range from 0.47 to 0.58 percent and generally increase with depth. The carbon isotope composition of the coalbed gases range from -49.3 to -43.3 permil $\delta^{13} \mathrm{C}$ with slightly heavier isotope values at depth (Smith, 1995). In general, biogenic methane is isotopically light with methane $\delta^{13} \mathrm{C}$ values ranging from -55 to -90 permil (Rice and Claypool, 1981; Rice, 1993). However, biogenic methane can be as heavy as -40 permil, which can be produced by reduction of isotopically heavy carbon dioxide (Jenden and Kaplan, 1986). Thus, the gas from the Tyonek coal beds may be slightly biogenic but mostly thermogenic. Chemical composition is 98-99 percent methane with minor amounts of carbon dioxide and nitrogen (see table 9; Flores and others, 1998).

Attempts to develop Tyonek coal beds by energy companies (Union and Ocean Energy) in the Wasilla area were affected by coproduced water problems. Large amounts of ground water were encountered, which posed production problems in separating the coalbed methane from the coproduced water as well as water-disposal problems by reinjection. Similar problems were met by gas operators in developing the coal beds of the Fort Union Formation in the Powder River Basin of Wyoming. However, the gas operators in that area are permitted to dispose of coproduced water at the surface. Other targets for coalbed methane development in the Upper

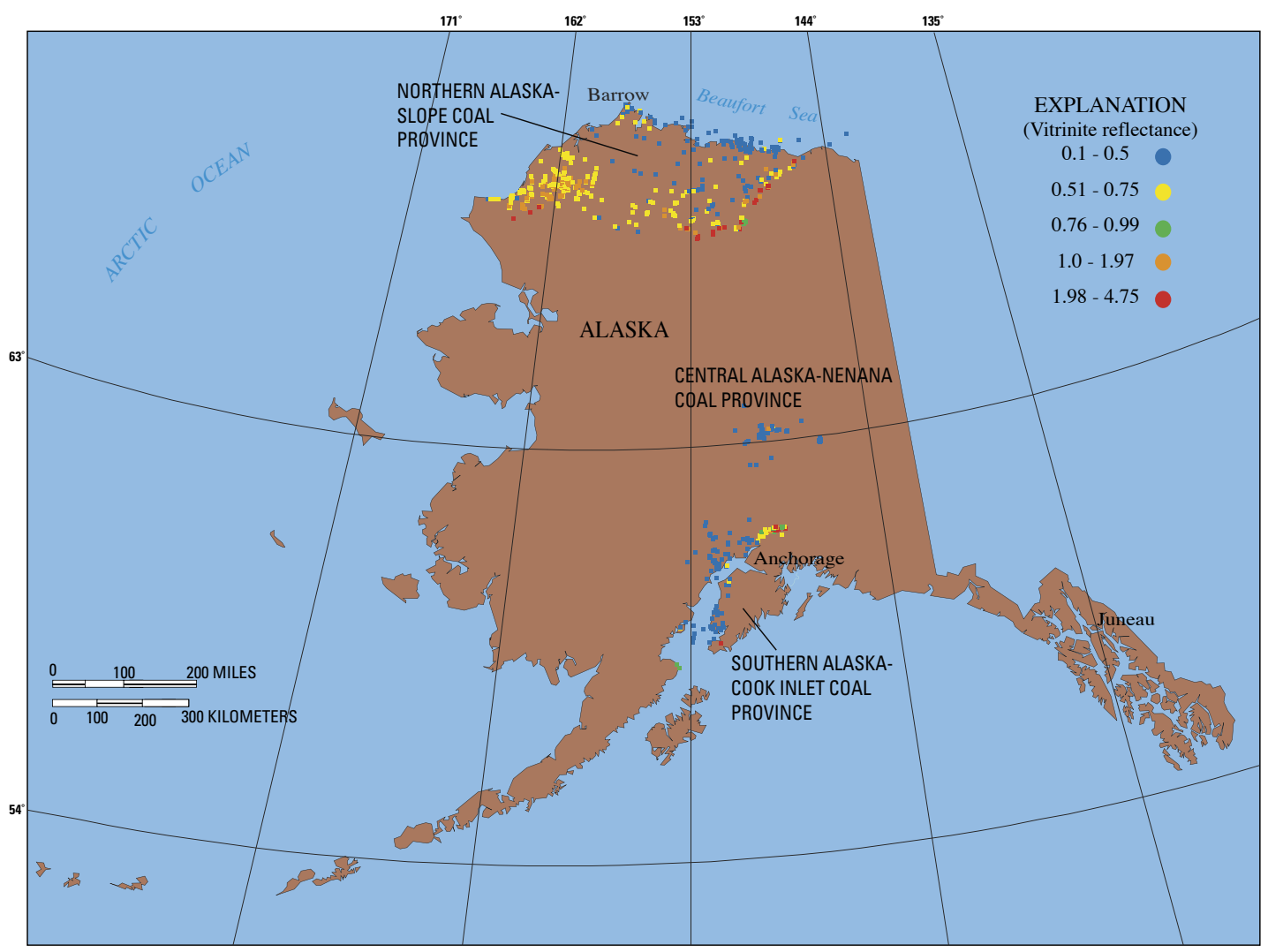

Figure 104. Map showing surface vitrinite reflectance values in the Northern Alaska-Slope, Central Alaska-Nenana, and Southern Alaska-Cook Inlet coal provinces. 
Table 8a. Vitrinite reflectance values of coals across the surface in the Northern AlaskaSlope, Central Alaska-Nenana, and Southern Alaska-Cook Inlet coal provinces. [Modified from Johnsson and others, 1992]

\begin{tabular}{|c|c|c|c|c|c|}
\hline $\begin{array}{l}\text { Record } \\
\text { number }\end{array}$ & $\begin{array}{c}\text { Quadrangle scale } \\
\text { of } 1: 250,000\end{array}$ & $\begin{array}{c}\text { North } \\
\text { latitude }\end{array}$ & $\begin{array}{c}\text { West } \\
\text { longitude }\end{array}$ & Formation & $\begin{array}{l}\text { Mean } \\
\mathbf{R}_{0}(\%) \\
\end{array}$ \\
\hline VO-0063 & Afognak & 58.8580 & 153.2860 & West Forelands & 3.36 \\
\hline VO-0068 & Afognak & 58.9460 & 153.4070 & West Forelands & 3.76 \\
\hline VO-0070 & Anchorage & 61.6500 & 149.8530 & Kenai & 0.47 \\
\hline VO-0071 & Anchorage & 61.6650 & 149.0730 & Chickaloon & 0.75 \\
\hline VO-0075 & Anchorage & 61.6800 & 148.1330 & Kenai & 0.66 \\
\hline VO-0081 & Anchorage & 61.6950 & 149.2520 & Kenai & 0.58 \\
\hline VO-0082 & Anchorage & 61.7080 & 149.0690 & Chickaloon & 0.65 \\
\hline VO-0084 & Anchorage & 61.7080 & 149.1020 & Chickaloon & 0.65 \\
\hline VO-0085 & Anchorage & 61.7380 & 148.9500 & Chickaloon & 0.61 \\
\hline VO-0091 & Anchorage & 61.7478 & 148.5364 & Chickaloon & 2.85 \\
\hline VO-0092 & Anchorage & 61.7489 & 148.5403 & Chickaloon & 3.42 \\
\hline VO-0093 & Anchorage & 61.7536 & 148.9081 & Chickaloon & 0.55 \\
\hline VO-0094 & Anchorage & 61.7581 & 148.8819 & Chickaloon & 0.54 \\
\hline VO-0096 & Anchorage & 61.7661 & 148.7311 & Chickaloon & 3.69 \\
\hline VO-0097 & Anchorage & 61.7670 & 149.1330 & Arkose Ridge & 2.10 \\
\hline VO-0099 & Anchorage & 61.7797 & 148.4147 & Chickaloon & 1.06 \\
\hline VO-0105 & Anchorage & 61.7833 & 148.7006 & Chickaloon & 0.82 \\
\hline VO-0106 & Anchorage & 61.7861 & 148.4306 & Chickaloon & 1.08 \\
\hline VO-0107 & Anchorage & 61.7883 & 148.4325 & Chickaloon & 1.30 \\
\hline VO-0109 & Anchorage & 61.7886 & 148.6883 & Chickaloon & 0.92 \\
\hline VO-0110 & Anchorage & 61.8033 & 148.3228 & Chickaloon & 1.55 \\
\hline VO-0111 & Anchorage & 61.8056 & 147.9753 & Chickaloon & 1.73 \\
\hline VO-0118 & Anchorage & 61.8078 & 148.4456 & Chickaloon & 1.42 \\
\hline VO-0121 & Anchorage & 61.8100 & 148.5570 & Chickaloon & 1.07 \\
\hline VO-0122 & Anchorage & 61.8131 & 148.6989 & Chickaloon & 0.74 \\
\hline VO-0124 & Anchorage & 61.8153 & 148.9464 & Chickaloon & 0.55 \\
\hline VO-0127 & Anchorage & 61.8169 & 148.5881 & Chickaloon & 1.26 \\
\hline VO-0130 & Anchorage & 61.8228 & 148.1406 & Chickaloon & 2.00 \\
\hline VO-0132 & Anchorage & 61.8228 & 148.4278 & Chickaloon & 1.12 \\
\hline VO-0135 & Anchorage & 61.8250 & 148.5469 & Chickaloon & 2.04 \\
\hline VO-0138 & Anchorage & 61.8289 & 148.5375 & Chickaloon & 2.07 \\
\hline VO-0139 & Anchorage & 61.8375 & 148.3922 & Chickaloon & 0.94 \\
\hline VO-0141 & Anchorage & 61.8378 & 148.0131 & Chickaloon & 0.84 \\
\hline VO-0143 & Anchorage & 61.8392 & 147.9908 & Chickaloon & 2.92 \\
\hline VO-0146 & Anchorage & 61.8392 & 148.0028 & Chickaloon & 0.81 \\
\hline VO-0147 & Anchorage & 61.8408 & 148.0131 & Chickaloon & 0.76 \\
\hline VO-0152 & Anchorage & 61.8408 & 148.5131 & Chickaloon & 0.64 \\
\hline VO-0153 & Anchorage & 61.8414 & 147.9908 & Chickaloon & 0.81 \\
\hline VO-0155 & Anchorage & 61.8417 & 148.0019 & Chickaloon & 0.76 \\
\hline VO-0156 & Anchorage & 61.8417 & 148.0039 & Chickaloon & 0.71 \\
\hline VO-0158 & Anchorage & 61.8461 & 148.0947 & Chickaloon & 3.27 \\
\hline
\end{tabular}


Table 8a. Vitrinite reflectance values of coals across the surface in the Northern AlaskaSlope, Central Alaska-Nenana, and Southern Alaska-Cook Inlet coal provinces. - Continued

\begin{tabular}{|c|c|c|c|c|c|}
\hline $\begin{array}{l}\text { Record } \\
\text { number }\end{array}$ & $\begin{array}{c}\text { Quadrangle scale } \\
\text { of } 1: 250,000\end{array}$ & $\begin{array}{l}\text { North } \\
\text { latitude }\end{array}$ & $\begin{array}{c}\text { West } \\
\text { longitude }\end{array}$ & Formation & $\begin{array}{l}\text { Mean } \\
\mathbf{R}_{0}(\%) \\
\end{array}$ \\
\hline VO-0160 & Anchorage & 61.8472 & 148.1006 & Chickaloon & 4.08 \\
\hline VO-0161 & Anchorage & 61.8472 & 148.1050 & Chickaloon & 3.88 \\
\hline VO-0164 & Anchorage & 61.8497 & 148.1033 & Chickaloon & 3.74 \\
\hline VO-0165 & Anchorage & 61.8511 & 148.1022 & Chickaloon & 4.75 \\
\hline VO-0168 & Anchorage & 61.8550 & 148.4380 & Chickaloon & 1.15 \\
\hline VO-0647 & Chandler Lake & 68.3236 & 151.8950 & Okpikruak & 1.32 \\
\hline VO-0648 & Chandler Lake & 68.3458 & 151.8708 & Okpikruak & 1.60 \\
\hline VO-0649 & Chandler Lake & 68.3569 & 151.8750 & Okpikruak & 1.18 \\
\hline VO-0656 & Chandler Lake & 68.3867 & 151.8708 & Torok & 1.31 \\
\hline VO-0666 & Chandler Lake & 68.4131 & 150.9178 & Okpikruak & 1.58 \\
\hline VO-0673 & Chandler Lake & 68.4575 & 150.9247 & Okpikruak & 1.23 \\
\hline VO-0679 & Chandler Lake & 68.4625 & 152.0250 & Torok & 0.94 \\
\hline VO-0694 & Chandler Lake & 68.5250 & 150.4733 & Torok & 0.99 \\
\hline VO-0696 & Chandler Lake & 68.5272 & 150.4775 & Torok & 1.01 \\
\hline VO-0700 & Chandler Lake & 68.5450 & 152.4783 & Fortress Mountain & 0.96 \\
\hline VO-0701 & Chandler Lake & 68.5458 & 152.5000 & Fortress Mountain & 0.93 \\
\hline VO-0702 & Chandler Lake & 68.5536 & 150.1472 & Torok & 1.38 \\
\hline VO-0703 & Chandler Lake & 68.5661 & 152.5822 & Fortress Mountain & 0.64 \\
\hline VO-0704 & Chandler Lake & 68.5700 & 152.9797 & Fortress Mountain & 0.71 \\
\hline VO-0707 & Chandler Lake & 68.5700 & 152.9822 & Fortress Mountain & 0.74 \\
\hline VO-0708 & Chandler Lake & 68.5706 & 152.5639 & Fortress Mountain & 0.65 \\
\hline VO-0709 & Chandler Lake & 68.5708 & 152.9767 & Fortress Mountain & 0.76 \\
\hline VO-0710 & Chandler Lake & 68.5711 & 152.5869 & Fortress Mountain & 1.08 \\
\hline VO-0715 & Chandler Lake & 68.6294 & 150.5692 & Killik Tongue & 0.56 \\
\hline VO-0716 & Chandler Lake & 68.6314 & 150.5703 & Killik Tongue & 0.72 \\
\hline VO-0717 & Chandler Lake & 68.6403 & 150.5783 & Killik Tongue & 0.49 \\
\hline VO-0718 & Chandler Lake & 68.6464 & 150.5883 & Killik Tongue & 0.52 \\
\hline VO-0719 & Chandler Lake & 68.6508 & 150.5936 & Killik Tongue & 0.56 \\
\hline VO-0720 & Chandler Lake & 68.6578 & 150.5950 & Killik Tongue & 0.59 \\
\hline VO-0722 & Chandler Lake & 68.6447 & 150.9036 & Nanushuk Gp & 0.74 \\
\hline VO-0724 & Chandler Lake & 68.6692 & 150.6086 & Tuktu & 0.55 \\
\hline VO-0727 & Chandler Lake & 68.7694 & 152.1150 & Killik Tongue & 0.68 \\
\hline VO-0731 & Chandler Lake & 68.7581 & 152.1403 & Killik Tongue & 0.47 \\
\hline VO-0732 & Chandler Lake & 68.7375 & 152.1472 & Killik Tongue & 0.59 \\
\hline VO-0733 & Chandler Lake & 68.7344 & 152.2569 & Killik Tongue & 0.50 \\
\hline VO-0734 & Chandler Lake & 68.7250 & 152.2639 & Killik Tongue & 0.62 \\
\hline VO-0735 & Chandler Lake & 68.8431 & 150.5611 & Tuktu & 0.51 \\
\hline VO-0736 & Chandler Lake & 68.8436 & 150.5586 & Tuktu & 0.56 \\
\hline VO-0737 & Chandler Lake & 68.8417 & 150.5803 & Shale Wall Mbr & 0.46 \\
\hline VO-0738 & Chandler Lake & 68.8417 & 150.5792 & Shale Wall Mbr & 0.47 \\
\hline VO-0739 & Chandler Lake & 68.9294 & 151.2175 & Killik Tongue & 0.55 \\
\hline VO-1177 & De Long Mountains & 68.5325 & 163.5330 & Fortress Mountain & 1.10 \\
\hline VO-1179 & De Long Mountains & 68.7408 & 163.8864 & Corwin & 0.59 \\
\hline VO-1180 & De Long Mountains & 68.7400 & 163.8844 & Unnamed & 0.63 \\
\hline
\end{tabular}


Table 8a. Vitrinite reflectance values of coals across the surface in the Northern AlaskaSlope, Central Alaska-Nenana, and Southern Alaska-Cook Inlet coal provinces. - Continued

\begin{tabular}{|c|c|c|c|c|c|}
\hline $\begin{array}{l}\text { Record } \\
\text { number }\end{array}$ & $\begin{array}{c}\text { Quadrangle scale } \\
\text { of } 1: 250,000\end{array}$ & $\begin{array}{c}\text { North } \\
\text { latitude }\end{array}$ & $\begin{array}{c}\text { West } \\
\text { longitude }\end{array}$ & Formation & $\begin{array}{l}\text { Mean } \\
\mathrm{R}_{0}(\%)\end{array}$ \\
\hline VO-1181 & De Long Mountains & 68.7564 & 163.9106 & Torok & 0.69 \\
\hline VO-1182 & De Long Mountains & 68.7814 & 162.9556 & Torok & 0.71 \\
\hline VO-1183 & De Long Mountains & 68.7869 & 162.9419 & Kukpowruk & 0.88 \\
\hline VO-1184 & De Long Mountains & 68.7850 & 162.9492 & Unnamed & 0.87 \\
\hline VO-1185 & De Long Mountains & 68.8078 & 163.9614 & Torok & 0.85 \\
\hline VO-1186 & De Long Mountains & 68.8150 & 163.9358 & Unnamed & 0.66 \\
\hline VO-1187 & De Long Mountains & 68.8106 & 163.9453 & Unnamed & 0.78 \\
\hline VO-1188 & De Long Mountains & 68.7764 & 163.9511 & Unnamed & 0.79 \\
\hline VO-1189 & De Long Mountains & 68.8086 & 163.9594 & Unnamed & 0.89 \\
\hline VO-1190 & De Long Mountains & 68.8489 & 163.8611 & Unnamed & 0.80 \\
\hline VO-1192 & De Long Mountains & 68.8636 & 163.8611 & Kukpowruk & 0.74 \\
\hline VO-1193 & De Long Mountains & 68.8600 & 163.1111 & Unnamed & 0.93 \\
\hline VO-1194 & De Long Mountains & 68.8542 & 163.1022 & Unnamed & 0.90 \\
\hline VO-1195 & De Long Mountains & 68.8494 & 163.0950 & Unnamed & 0.86 \\
\hline VO-1196 & De Long Mountains & 68.8397 & 163.0767 & Unnamed & 0.90 \\
\hline VO-1197 & De Long Mountains & 68.7972 & 163.1208 & Unnamed & 0.85 \\
\hline VO-1198 & De Long Mountains & 68.8925 & 164.6994 & Nanushuk Gp & 0.72 \\
\hline VO-1199 & De Long Mountains & 68.8925 & 164.8364 & Nanushuk Gp & 0.68 \\
\hline VO-1205 & De Long Mountains & 68.8925 & 164.8489 & Nanushuk Gp & 0.58 \\
\hline VO-1210 & De Long Mountains & 68.8936 & 164.8147 & Nanushuk Gp & 0.60 \\
\hline VO-1212 & De Long Mountains & 68.8947 & 164.7992 & Nanushuk Gp & 0.49 \\
\hline VO-1213 & De Long Mountains & 68.8958 & 164.7772 & Nanushuk Gp & 0.67 \\
\hline VO-1214 & De Long Mountains & 68.8969 & 164.7742 & Nanushuk Gp & 0.72 \\
\hline VO-1215 & De Long Mountains & 68.8981 & 164.7556 & Nanushuk Gp & 0.69 \\
\hline VO-1216 & De Long Mountains & 68.9631 & 162.8450 & Unnamed & 0.69 \\
\hline VO-1217 & De Long Mountains & 68.9647 & 162.8442 & Unnamed & 0.69 \\
\hline VO-1218 & De Long Mountains & 68.9714 & 162.8050 & Unnamed & 0.71 \\
\hline VO-1219 & De Long Mountains & 68.9822 & 162.8000 & Unnamed & 0.80 \\
\hline VO-1220 & De Long Mountains & 68.9950 & 162.8161 & Unnamed & 0.80 \\
\hline VO-1221 & Point Lay & 69.0019 & 162.8144 & Unnamed & 0.76 \\
\hline VO-1222 & Point Lay & 69.0056 & 162.8439 & Unnamed & 0.81 \\
\hline VO-1223 & Point Lay & 69.0108 & 162.8469 & Unnamed & 0.68 \\
\hline VO-1224 & Point Lay & 69.0161 & 162.9081 & Unnamed & 0.68 \\
\hline VO-1225 & De Long Mountains & 68.9653 & 163.8408 & Nanushuk Gp & 0.86 \\
\hline VO-1226 & De Long Mountains & 68.9722 & 163.9314 & Nanushuk Gp & 0.73 \\
\hline VO-1228 & De Long Mountains & 68.9725 & 163.8442 & Corwin & 0.74 \\
\hline VO-1229 & De Long Mountains & 68.9772 & 163.8561 & Corwin & 0.74 \\
\hline VO-1231 & De Long Mountains & 68.9878 & 163.8692 & Nanushuk Gp & 0.70 \\
\hline VO-1232 & De Long Mountains & 68.9925 & 163.8625 & Corwin & 0.73 \\
\hline VO-1235 & De Long Mountains & 68.9931 & 163.8650 & Corwin & 0.71 \\
\hline VO-1238 & De Long Mountains & 68.9939 & 163.8903 & Corwin & 0.72 \\
\hline VO-1241 & De Long Mountains & 68.9953 & 163.7619 & Corwin & 0.72 \\
\hline VO-1242 & De Long Mountains & 68.9989 & 163.7714 & Corwin & 0.73 \\
\hline VO-1243 & De Long Mountains & 68.9997 & 163.8722 & Corwin & 0.66 \\
\hline
\end{tabular}


Table 8a. Vitrinite reflectance values of coals across the surface in the Northern AlaskaSlope, Central Alaska-Nenana, and Southern Alaska-Cook Inlet coal provinces. - Continued

\begin{tabular}{|c|c|c|c|c|c|}
\hline $\begin{array}{l}\text { Record } \\
\text { number }\end{array}$ & $\begin{array}{c}\text { Quadrangle scale } \\
\text { of } 1: 250,000\end{array}$ & $\begin{array}{l}\text { North } \\
\text { latitude }\end{array}$ & $\begin{array}{c}\text { West } \\
\text { longitude }\end{array}$ & Formation & $\begin{array}{l}\text { Mean } \\
\mathbf{R}_{0}(\%)\end{array}$ \\
\hline VO-1345 & Fairbanks & 64.0050 & 148.2470 & Suntrana & 0.30 \\
\hline VO-1347 & Fairbanks & 64.0067 & 148.7842 & Grubstake/Lignite $\mathrm{Ck}$ & 0.21 \\
\hline VO-1348 & Fairbanks & 64.0111 & 148.2842 & Suntrana & 0.35 \\
\hline VO-1351 & Fairbanks & 64.0167 & 148.1400 & Unnamed & 0.63 \\
\hline VO-1355 & Fairbanks & 64.0180 & 148.2050 & Lignite Creek & 0.29 \\
\hline VO-1356 & Fairbanks & 64.0181 & 148.7433 & Suntrana & 0.27 \\
\hline VO-1357 & Fairbanks & 64.0350 & 148.4100 & Grubstake & 0.82 \\
\hline VO-1358 & Fairbanks & 64.0772 & 148.2072 & Grubstake & 0.50 \\
\hline VO-1362 & Fairbanks & 64.1017 & 148.7333 & Sanctuary & 0.33 \\
\hline VO-1366 & Fairbanks & 64.1050 & 148.8350 & Healy Creek & 0.31 \\
\hline VO-1367 & Fairbanks & 64.1220 & 148.7380 & Healy Creek & 0.33 \\
\hline VO-1369 & Fairbanks & 64.1283 & 146.6261 & Healy Creek & 0.29 \\
\hline VO-1372 & Healy & 63.2500 & 149.1870 & Unnamed & 0.23 \\
\hline VO-1373 & Healy & 63.2700 & 149.5050 & Unnamed & 0.41 \\
\hline VO-1482 & Healy & 63.7394 & 149.7033 & Healy Creek & 0.24 \\
\hline VO-1487 & Healy & 63.7661 & 149.6017 & Sanctuary & 0.31 \\
\hline VO-1489 & Healy & 63.7681 & 149.5811 & Unnamed & 0.28 \\
\hline VO-1490 & Healy & 63.7903 & 149.5056 & Healy Creek & 0.27 \\
\hline VO-1492 & Healy & 63.7928 & 149.5067 & Sanctuary & 0.29 \\
\hline VO-1495 & Healy & 63.8300 & 148.6670 & Suntrana & 0.30 \\
\hline VO-1497 & Healy & 63.8550 & 148.8400 & Healy Creek & 0.38 \\
\hline VO-1513 & Healy & 63.8567 & 148.8400 & Suntrama & 0.39 \\
\hline VO-1516 & Healy & 63.8567 & 148.8433 & Unnamed & 0.39 \\
\hline VO-1517 & Healy & 63.8567 & 148.8533 & Sanctuary & 0.40 \\
\hline VO-1519 & Healy & 63.8567 & 148.9200 & Lignite Creek & 0.33 \\
\hline VO-1521 & Healy & 63.8570 & 148.8330 & Healy Creek & 0.29 \\
\hline VO-1529 & Healy & 63.8580 & 148.7380 & Suntrana & 0.26 \\
\hline VO-1530 & Healy & 63.8583 & 148.8533 & Suntrama & 0.34 \\
\hline VO-1576 & Healy & 63.8617 & 148.8533 & Unnamed & 0.22 \\
\hline VO-1581 & Healy & 63.9000 & 148.9000 & Suntrana & 0.25 \\
\hline VO-1582 & Healy & 63.9006 & 148.9139 & Suntrama & 0.28 \\
\hline VO-1584 & Healy & 63.9020 & 148.9330 & Suntrana & 0.24 \\
\hline VO-1588 & Healy & 63.9025 & 148.9317 & Suntrama & 0.32 \\
\hline VO-1595 & Healy & 63.9028 & 148.9150 & Suntrama & 0.37 \\
\hline VO-1596 & Healy & 63.9150 & 148.9000 & Suntrana & 0.27 \\
\hline VO-1597 & Healy & 63.9167 & 148.6956 & Sanctuary & 0.28 \\
\hline VO-1600 & Healy & 63.9180 & 148.8567 & Healy Creek & 0.32 \\
\hline VO-1602 & Healy & 63.9217 & 148.6850 & Sanctuary & 0.40 \\
\hline VO-1621 & Healy & 63.9267 & 148.4700 & Healy Creek & 0.43 \\
\hline VO-1622 & Healy & 63.9294 & 147.4872 & Healy Creek & 0.41 \\
\hline VO-1627 & Healy & 63.9350 & 147.4311 & Unnamed & 0.50 \\
\hline VO-1630 & Healy & 63.9375 & 148.5894 & Suntrana & 0.34 \\
\hline VO-1631 & Healy & 63.9430 & 148.6350 & Suntrana & 0.26 \\
\hline VO-1632 & Healy & 63.9431 & 148.6381 & Suntrana & 0.30 \\
\hline
\end{tabular}


Table 8a. Vitrinite reflectance values of coals across the surface in the Northern AlaskaSlope, Central Alaska-Nenana, and Southern Alaska-Cook Inlet coal provinces. - Continued

\begin{tabular}{|c|c|c|c|c|c|}
\hline $\begin{array}{l}\text { Record } \\
\text { number }\end{array}$ & $\begin{array}{c}\text { Quadrangle scale } \\
\text { of } 1: 250,000\end{array}$ & $\begin{array}{l}\text { North } \\
\text { latitude }\end{array}$ & $\begin{array}{c}\text { West } \\
\text { longitude }\end{array}$ & Formation & $\begin{array}{l}\text { Mean } \\
\mathbf{R}_{0}(\%)\end{array}$ \\
\hline VO-1634 & Healy & 63.9453 & 147.4106 & Unnamed & 0.44 \\
\hline VO-1635 & Healy & 63.9453 & 148.6814 & Suntrana & 0.29 \\
\hline VO-1638 & Healy & 63.9667 & 147.9986 & Unnamed & 0.43 \\
\hline VO-1640 & Healy & 63.9711 & 147.9972 & Unnamed & 0.36 \\
\hline VO-1641 & Healy & 63.9733 & 148.7456 & Suntrana & 0.30 \\
\hline VO-1643 & Healy & 63.9750 & 148.7680 & Suntrana & 0.22 \\
\hline VO-1644 & Healy & 63.9833 & 147.9119 & Healy Creek & 0.42 \\
\hline VO-1647 & Healy & 63.9867 & 147.8397 & Healy Creek & 0.42 \\
\hline VO-1650 & Healy & 63.9933 & 147.8425 & Suntrana & 0.27 \\
\hline VO-1653 & Healy & 63.9933 & 147.9272 & Suntrana & 0.27 \\
\hline VO-1657 & Howard Pass & 68.5467 & 156.9608 & Fortress Mountain & 0.46 \\
\hline VO-1660 & Howard Pass & 68.5800 & 157.0814 & Fortress Mountain & 0.52 \\
\hline VO-1661 & Howard Pass & 68.6917 & 156.2356 & Fortress Mountain & 0.54 \\
\hline VO-1663 & Howard Pass & 68.7550 & 158.4439 & Fortress Mountain & 0.60 \\
\hline VO-1664 & Howard Pass & 68.7556 & 158.4439 & Fortress Mountain & 0.65 \\
\hline VO-1665 & Howard Pass & 68.7564 & 158.4439 & Fortress Mountain & 0.61 \\
\hline VO-1666 & Howard Pass & 68.7569 & 158.4369 & Fortress Mountain & 0.64 \\
\hline VO-1667 & Howard Pass & 68.7614 & 158.1589 & Fortress Mountain & 0.44 \\
\hline VO-1670 & Howard Pass & 68.9156 & 156.0253 & Fortress Mountain & 0.57 \\
\hline VO-1714 & Ikpikpuk River & 69.0256 & 155.8794 & Killik Tongue & 0.58 \\
\hline VO-1715 & Ikpikpuk River & 69.0294 & 155.8733 & Killik Tongue & 0.58 \\
\hline VO-1716 & Ikpikpuk River & 69.0267 & 155.8781 & Killik Tongue & 0.59 \\
\hline VO-1717 & Ikpikpuk River & 69.0792 & 156.0217 & Unnamed & 0.57 \\
\hline VO-1718 & Ikpikpuk River & 69.0758 & 156.0044 & Tuktu & 0.57 \\
\hline VO-1719 & Ikpikpuk River & 69.1208 & 153.2917 & Seabee & 0.55 \\
\hline VO-1721 & Ikpikpuk River & 69.1208 & 153.2903 & Seabee & 0.49 \\
\hline VO-1722 & Ikpikpuk River & 69.1250 & 153.2889 & Seabee & 0.52 \\
\hline VO-1723 & Ikpikpuk River & 69.1292 & 153.1819 & Seabee & 0.52 \\
\hline VO-1724 & Ikpikpuk River & 69.1292 & 153.2819 & Ninuluk & 0.55 \\
\hline VO-1725 & Ikpikpuk River & 69.1692 & 155.0064 & Nanushuk Gp & 0.44 \\
\hline VO-1759 & Kantishna River & 64.0350 & 150.1967 & Unnamed & 0.21 \\
\hline VO-1771 & Kenai & 60.0570 & 151.6550 & Beluga & 0.23 \\
\hline VO-1773 & Kenai & 60.0780 & 151.4930 & Sterling & 0.31 \\
\hline VO-1780 & Kenai & 60.1130 & 151.5700 & Sterling & 0.28 \\
\hline VO-1788 & Kenai & 60.9750 & 151.7170 & Kenai & 0.29 \\
\hline VO-1818 & Killik River & 68.6189 & 153.0280 & Fortress Mountain & 0.63 \\
\hline VO-1819 & Killik River & 68.6383 & 155.7569 & Fortress Mountain & 0.58 \\
\hline VO-1820 & Killik River & 68.6383 & 155.7614 & Fortress Mountain & 0.73 \\
\hline VO-1821 & Killik River & 68.8675 & 153.3917 & Killik Tongue & 0.57 \\
\hline VO-1822 & Killik River & 68.8656 & 153.3889 & Unnamed & 0.71 \\
\hline VO-1823 & Killik River & 68.8633 & 153.3828 & Unnamed & 0.66 \\
\hline VO-1824 & Killik River & 68.9111 & 153.3792 & Unnamed & 0.62 \\
\hline VO-1825 & Killik River & 68.8533 & 153.3683 & Unnamed & 0.60 \\
\hline VO-1826 & Killik River & 68.8789 & 155.1058 & Tuktu & 0.61 \\
\hline
\end{tabular}


Table 8a. Vitrinite reflectance values of coals across the surface in the Northern AlaskaSlope, Central Alaska-Nenana, and Southern Alaska-Cook Inlet coal provinces. - Continued

\begin{tabular}{|c|c|c|c|c|c|}
\hline $\begin{array}{l}\text { Record } \\
\text { number }\end{array}$ & $\begin{array}{c}\text { Quadrangle scale } \\
\text { of } 1: 250,000\end{array}$ & $\begin{array}{c}\text { North } \\
\text { latitude }\end{array}$ & $\begin{array}{c}\text { West } \\
\text { longitude }\end{array}$ & Formation & $\begin{array}{l}\text { Mean } \\
\mathbf{R}_{0}(\%) \\
\end{array}$ \\
\hline VO-1827 & Killik River & 68.9178 & 155.0756 & Unnamed & 0.62 \\
\hline VO-1828 & Killik River & 68.9081 & 155.0922 & Unnamed & 0.63 \\
\hline VO-1829 & Killik River & 68.8994 & 155.1053 & Unnamed & 0.57 \\
\hline VO-1830 & Killik River & 68.8939 & 155.1056 & Unnamed & 0.60 \\
\hline VO-1831 & Killik River & 68.8911 & 155.1056 & Unnamed & 0.64 \\
\hline VO-1832 & Killik River & 68.8831 & 155.1056 & Unnamed & 0.61 \\
\hline VO-1833 & Killik River & 68.8814 & 155.1056 & Unnamed & 0.62 \\
\hline VO-1835 & Killik River & 68.8806 & 155.1058 & Unnamed & 0.53 \\
\hline VO-1836 & Killik River & 68.8794 & 155.1058 & Unnamed & 0.60 \\
\hline VO-1837 & Killik River & 68.9597 & 153.5472 & Niakogon Tongue & 0.58 \\
\hline VO-1838 & Killik River & 68.9706 & 153.5519 & Niakogon Tongue & 0.56 \\
\hline VO-1839 & Killik River & 68.9750 & 153.9611 & Killik Tongue & 0.80 \\
\hline VO-1840 & Killik River & 68.9778 & 153.9625 & Killik Tongue & 0.76 \\
\hline VO-1841 & Killik River & 68.9786 & 153.9625 & Killik Tongue & 0.63 \\
\hline VO-1842 & Killik River & 68.9800 & 153.9639 & Killik Tongue & 0.60 \\
\hline VO-1843 & Killik River & 68.8472 & 153.9639 & Killik Tongue & 0.83 \\
\hline VO-1844 & Killik River & 68.9819 & 153.9653 & Killik Tongue & 0.84 \\
\hline VO-1916 & Lookout Ridge & 69.2239 & 158.7597 & Torok & 0.61 \\
\hline VO-1917 & Lookout Ridge & 69.2428 & 158.7419 & Corwin & 0.50 \\
\hline VO-1918 & Lookout Ridge & 69.2272 & 158.7553 & Corwin & 0.57 \\
\hline VO-1919 & Lookout Ridge & 69.2250 & 158.7567 & Corwin & 0.59 \\
\hline VO-1920 & Lookout Ridge & 69.4575 & 158.7206 & Nanushuk Gp & 0.71 \\
\hline VO-1921 & Lookout Ridge & 69.4900 & 158.7114 & Nanushuk Gp & 0.76 \\
\hline VO-1922 & Lookout Ridge & 69.5336 & 158.6861 & Nanushuk Gp & 0.73 \\
\hline VO-1923 & Lookout Ridge & 69.6078 & 158.6222 & Nanushuk Gp & 0.60 \\
\hline VO-1924 & Lookout Ridge & 69.6189 & 158.6161 & Nanushuk Gp & 0.75 \\
\hline VO-1925 & Lookout Ridge & 69.6256 & 158.6128 & Nanushuk Gp & 0.68 \\
\hline VO-1926 & Lookout Ridge & 69.6369 & 158.6097 & Nanushuk Gp & 0.56 \\
\hline VO-1927 & Lookout Ridge & 69.7039 & 158.5872 & Nanushuk Gp & 0.60 \\
\hline VO-1928 & Lookout Ridge & 69.7297 & 158.5778 & Nanushuk Gp & 0.58 \\
\hline VO-1929 & Lookout Ridge & 69.8622 & 158.5194 & Nanushuk Gp & 0.58 \\
\hline VO-2071 & Misheguk Mountain & 68.8819 & 161.8667 & Corwin & 0.68 \\
\hline VO-2072 & Misheguk Mountain & 68.8822 & 161.8667 & Corwin & 0.77 \\
\hline VO-2073 & Misheguk Mountain & 68.8792 & 161.8722 & Corwin & 0.80 \\
\hline VO-2074 & Misheguk Mountain & 68.8681 & 161.9042 & Corwin & 0.83 \\
\hline VO-2075 & Misheguk Mountain & 68.8667 & 161.9056 & Corwin & 0.74 \\
\hline VO-2076 & Misheguk Mountain & 68.8653 & 161.9208 & Corwin & 0.80 \\
\hline VO-2077 & Misheguk Mountain & 68.8639 & 161.9278 & Corwin & 0.82 \\
\hline VO-2078 & Misheguk Mountain & 68.8583 & 161.9597 & Corwin & 0.90 \\
\hline VO-2079 & Misheguk Mountain & 68.8833 & 162.0250 & Corwin & 0.79 \\
\hline VO-2080 & Misheguk Mountain & 68.8686 & 162.0250 & Corwin & 0.80 \\
\hline VO-2081 & Misheguk Mountain & 68.8672 & 162.0333 & Corwin & 0.87 \\
\hline VO-2082 & Misheguk Mountain & 68.8667 & 162.0417 & Corwin & 1.02 \\
\hline VO-2083 & Misheguk Mountain & 68.9225 & 159.1455 & Fortress Mountain & 0.73 \\
\hline
\end{tabular}


Table 8a. Vitrinite reflectance values of coals across the surface in the Northern AlaskaSlope, Central Alaska-Nenana, and Southern Alaska-Cook Inlet coal provinces. - Continued

\begin{tabular}{|c|c|c|c|c|c|}
\hline $\begin{array}{l}\text { Record } \\
\text { number }\end{array}$ & $\begin{array}{c}\text { Quadrangle scale } \\
\text { of } 1: 250,000\end{array}$ & $\begin{array}{c}\text { North } \\
\text { latitude }\end{array}$ & $\begin{array}{c}\text { West } \\
\text { longitude }\end{array}$ & Formation & $\begin{array}{l}\text { Mean } \\
\mathbf{R}_{0}(\%) \\
\end{array}$ \\
\hline VO-2085 & Misheguk Mountain & 68.9278 & 160.7917 & Kukpowruk & 0.53 \\
\hline VO-2086 & Misheguk Mountain & 68.9289 & 160.7944 & Kukpowruk & 0.52 \\
\hline VO-2087 & Misheguk Mountain & 68.9333 & 160.8000 & Kukpowruk & 0.51 \\
\hline VO-2088 & Misheguk Mountain & 68.9472 & 160.8069 & Kukpowruk & 0.63 \\
\hline VO-2089 & Misheguk Mountain & 68.9500 & 160.8111 & Kukpowruk & 0.59 \\
\hline VO-2090 & Misheguk Mountain & 68.9533 & 160.8125 & Kukpowruk & 0.66 \\
\hline VO-2091 & Misheguk Mountain & 68.9819 & 160.8569 & Torok & 0.60 \\
\hline VO-2092 & Mount Hayes & 63.3733 & 148.3800 & Healy Creek & 0.33 \\
\hline VO-2093 & Mount Hayes & 63.6028 & 145.7383 & Unnamed & 0.43 \\
\hline VO-2094 & Mount Hayes & 63.6039 & 145.7472 & Unnamed & 0.42 \\
\hline VO-2095 & Mount Hayes & 63.6131 & 145.7306 & Unnamed & 0.41 \\
\hline VO-2097 & Mount Hayes & 63.6181 & 145.7611 & Unnamed & 0.40 \\
\hline VO-2099 & Mount Hayes & 63.6183 & 145.7103 & Unnamed & 0.42 \\
\hline VO-2100 & Mount Hayes & 63.6211 & 145.7436 & Unnamed & 0.39 \\
\hline VO-2102 & Mount Hayes & 63.6222 & 145.7083 & Unnamed & 0.37 \\
\hline VO-2103 & Mount Hayes & 63.6231 & 145.7533 & Unnamed & 0.38 \\
\hline VO-2105 & Mount Hayes & 63.6250 & 145.7658 & Unnamed & 0.37 \\
\hline VO-2106 & Mount Hayes & 63.6253 & 145.7142 & Unnamed & 0.41 \\
\hline VO-2108 & Mount Hayes & 63.6253 & 145.7603 & Unnamed & 0.38 \\
\hline VO-2113 & Mount Hayes & 63.6258 & 145.7725 & Unnamed & 0.39 \\
\hline VO-2118 & Mount Hayes & 63.6269 & 145.7808 & Unnamed & 0.37 \\
\hline VO-2120 & Mount Hayes & 63.6281 & 145.7075 & Unnamed & 0.40 \\
\hline VO-2122 & Mount Hayes & 63.6283 & 145.6814 & Unnamed & 0.39 \\
\hline VO-2124 & Mount Hayes & 63.6303 & 145.7294 & Unnamed & 0.35 \\
\hline VO-2127 & Mount Hayes & 63.6311 & 145.7842 & Unnamed & 0.40 \\
\hline VO-2129 & Mount Hayes & 63.6317 & 145.7158 & Unnamed & 0.44 \\
\hline VO-2130 & Mount Hayes & 63.6325 & 145.8033 & Unnamed & 0.42 \\
\hline VO-2133 & Mount Hayes & 63.6328 & 145.6808 & Unnamed & 0.42 \\
\hline VO-2134 & Mount Hayes & 63.6344 & 145.7281 & Unnamed & 0.36 \\
\hline VO-2137 & Mount Hayes & 63.6389 & 145.7153 & Unnamed & 0.36 \\
\hline VO-2138 & Mount Hayes & 63.6439 & 145.7108 & Unnamed & 0.35 \\
\hline VO-2140 & Mount Hayes & 63.6447 & 145.7153 & Unnamed & 0.35 \\
\hline VO-2144 & Mount Hayes & 63.6469 & 145.7142 & Unnamed & 0.36 \\
\hline VO-2146 & Mount Hayes & 63.6558 & 145.7828 & Unnamed & 0.37 \\
\hline VO-2152 & Mount Hayes & 63.6570 & 145.7800 & Healy Creek & 0.30 \\
\hline VO-2153 & Mount Hayes & 63.6586 & 145.7133 & Unnamed & 0.35 \\
\hline VO-2156 & Mount Hayes & 63.6600 & 145.7172 & Unnamed & 0.34 \\
\hline VO-2157 & Mount Hayes & 63.6842 & 145.7417 & Unnamed & 0.39 \\
\hline VO-2158 & Mount Hayes & 63.6842 & 145.7475 & Unnamed & 0.34 \\
\hline VO-2159 & Mount Hayes & 63.6944 & 145.7469 & Unnamed & 0.38 \\
\hline VO-2160 & Mount Hayes & 63.7008 & 145.7314 & Unnamed & 0.38 \\
\hline VO-2285 & Mount Michelson & 69.6530 & 146.8569 & Sagavanirktok & 0.74 \\
\hline VO-2334 & Mount Michelson & 69.7133 & 145.5864 & Sagavanirktok & 0.75 \\
\hline VO-2341 & Mount Michelson & 69.7500 & 145.3375 & Sagavanirktok & 0.50 \\
\hline
\end{tabular}


Table 8a. Vitrinite reflectance values of coals across the surface in the Northern AlaskaSlope, Central Alaska-Nenana, and Southern Alaska-Cook Inlet coal provinces. - Continued

\begin{tabular}{|c|c|c|c|c|c|}
\hline $\begin{array}{l}\text { Record } \\
\text { number }\end{array}$ & $\begin{array}{c}\text { Quadrangle scale } \\
\text { of } 1: 250,000\end{array}$ & $\begin{array}{l}\text { North } \\
\text { latitude }\end{array}$ & $\begin{array}{c}\text { West } \\
\text { longitude }\end{array}$ & Formation & $\begin{array}{l}\text { Mean } \\
\mathbf{R}_{0}(\%)\end{array}$ \\
\hline VO-2342 & Mount Michelson & 69.7875 & 145.3125 & Sagavanirktok & 0.32 \\
\hline VO-2343 & Mount Michelson & 69.7944 & 145.3194 & Sagavanirktok & 0.77 \\
\hline VO-2344 & Mount Michelson & 69.8333 & 145.3500 & Sagavanirktok & 0.90 \\
\hline VO-2345 & Mount Michelson & 69.8611 & 145.2750 & Sagavanirktok & 1.91 \\
\hline VO-2347 & Mount Michelson & 69.9083 & 144.6500 & Sagavanirktok & 0.25 \\
\hline VO-2630 & Philip Smith Mountains & 68.4764 & 149.2725 & Torok & 1.70 \\
\hline VO-2631 & Philip Smith Mountains & 68.4775 & 149.2767 & Torok & 1.09 \\
\hline VO-2635 & Philip Smith Mountains & 68.4800 & 149.4100 & Fortress Mountain & 1.86 \\
\hline VO-2638 & Philip Smith Mountains & 68.4817 & 149.2822 & Torok & 1.01 \\
\hline VO-2640 & Philip Smith Mountains & 68.4831 & 149.2842 & Torok & 0.87 \\
\hline VO-2643 & Philip Smith Mountains & 68.4836 & 149.2853 & Torok & 0.91 \\
\hline VO-2645 & Philip Smith Mountains & 68.4858 & 149.2272 & Fortress Mountain & 1.27 \\
\hline VO-2646 & Philip Smith Mountains & 68.4872 & 149.4189 & Fortress Mountain & 0.63 \\
\hline VO-2647 & Philip Smith Mountains & 68.4903 & 149.4086 & Fortress Mountain & 0.67 \\
\hline VO-2648 & Philip Smith Mountains & 68.4925 & 149.3856 & Fortress Mountain & 0.50 \\
\hline VO-2649 & Philip Smith Mountains & 68.4933 & 149.4342 & Fortress Mountain & 0.71 \\
\hline VO-2652 & Philip Smith Mountains & 68.5203 & 149.4550 & Fortress Mountain & 0.58 \\
\hline VO-2654 & Philip Smith Mountains & 68.5325 & 149.2819 & Fortress Mountain & 0.86 \\
\hline VO-2661 & Philip Smith Mountains & 68.5864 & 148.9056 & Torok & 2.13 \\
\hline VO-2667 & Philip Smith Mountains & 68.6378 & 148.7928 & Torok & 2.96 \\
\hline VO-2670 & Philip Smith Mountains & 68.6408 & 148.7911 & Torok & 2.89 \\
\hline VO-2671 & Philip Smith Mountains & 68.6417 & 149.0833 & Fortress Mountain & 1.02 \\
\hline VO-2676 & Philip Smith Mountains & 68.6458 & 148.7872 & Torok & 2.91 \\
\hline VO-2677 & Philip Smith Mountains & 68.6475 & 148.7911 & Torok & 2.91 \\
\hline VO-2681 & Philip Smith Mountains & 68.6628 & 148.8933 & Torok & 2.65 \\
\hline VO-2687 & Philip Smith Mountains & 68.7267 & 149.0269 & Chandler & 0.70 \\
\hline VO-2688 & Philip Smith Mountains & 68.7278 & 149.0297 & Chandler & 0.72 \\
\hline VO-2689 & Philip Smith Mountains & 68.7278 & 149.0219 & Chandler & 0.74 \\
\hline VO-2690 & Philip Smith Mountains & 68.7375 & 149.0083 & Torok & 0.66 \\
\hline VO-2691 & Philip Smith Mountains & 68.7428 & 149.0639 & Unnamed & 0.47 \\
\hline VO-2692 & Philip Smith Mountains & 68.7417 & 149.0489 & Unnamed & 0.55 \\
\hline VO-2693 & Philip Smith Mountains & 68.7344 & 149.0256 & Unnamed & 0.52 \\
\hline VO-2694 & Philip Smith Mountains & 68.7339 & 149.0217 & Unnamed & 0.66 \\
\hline VO-2695 & Philip Smith Mountains & 68.7328 & 149.0206 & Unnamed & 0.71 \\
\hline VO-2696 & Philip Smith Mountains & 68.7275 & 149.0211 & Unnamed & 0.74 \\
\hline VO-2721 & Point Hope & 68.8719 & 165.1300 & Corwin & 0.58 \\
\hline VO-2722 & Point Hope & 68.8656 & 165.2306 & Corwin & 0.54 \\
\hline VO-2723 & Point Hope & 68.8644 & 165.2439 & Corwin & 0.57 \\
\hline VO-2724 & Point Hope & 68.8594 & 165.3281 & Corwin & 0.50 \\
\hline VO-2725 & Point Hope & 68.8769 & 165.0744 & Corwin & 0.60 \\
\hline VO-2726 & Point Hope & 68.8783 & 165.0508 & Corwin & 0.56 \\
\hline VO-2727 & Point Hope & 68.8794 & 165.0358 & Corwin & 0.60 \\
\hline VO-2728 & Point Hope & 68.8800 & 165.0278 & Corwin & 0.66 \\
\hline VO-2729 & Point Hope & 68.8808 & 165.0175 & Corwin & 0.62 \\
\hline
\end{tabular}


Table 8a. Vitrinite reflectance values of coals across the surface in the Northern AlaskaSlope, Central Alaska-Nenana, and Southern Alaska-Cook Inlet coal provinces. - Continued

\begin{tabular}{|c|c|c|c|c|c|}
\hline $\begin{array}{l}\text { Record } \\
\text { number }\end{array}$ & $\begin{array}{c}\text { Quadrangle scale } \\
\text { of } 1: 250,000\end{array}$ & $\begin{array}{c}\text { North } \\
\text { latitude }\end{array}$ & $\begin{array}{c}\text { West } \\
\text { longitude }\end{array}$ & Formation & $\begin{array}{l}\text { Mean } \\
R_{0}(\%)\end{array}$ \\
\hline VO-2730 & Point Hope & 68.8817 & 165.0033 & Corwin & 0.64 \\
\hline VO-2731 & Point Hope & 68.8819 & 164.9956 & Corwin & 0.67 \\
\hline VO-2732 & Point Hope & 68.8822 & 164.9889 & Corwin & 0.67 \\
\hline VO-2733 & Point Hope & 68.8839 & 164.8425 & Corwin & 0.67 \\
\hline VO-2734 & Point Hope & 68.8761 & 165.0942 & Corwin & 0.72 \\
\hline VO-2735 & Point Hope & 68.8756 & 165.1025 & Corwin & 0.58 \\
\hline VO-2736 & Point Hope & 68.8853 & 164.9578 & Corwin & 0.74 \\
\hline VO-2737 & Point Hope & 68.8872 & 164.9397 & Corwin & 0.71 \\
\hline VO-2738 & Point Hope & 68.8667 & 165.1681 & Nanushuk Gp & 0.57 \\
\hline VO-2739 & Point Hope & 68.8678 & 165.1369 & Nanushuk Gp & 0.64 \\
\hline VO-2740 & Point Hope & 68.8678 & 165.1619 & Nanushuk Gp & 0.55 \\
\hline VO-2741 & Point Hope & 68.8711 & 165.1275 & Nanushuk Gp & 0.61 \\
\hline VO-2742 & Point Hope & 68.8739 & 165.0686 & Nanushuk Gp & 0.70 \\
\hline VO-2743 & Point Hope & 68.8744 & 165.1153 & Nanushuk Gp & 0.69 \\
\hline VO-2744 & Point Hope & 68.8889 & 164.9222 & Kukpowruk & 0.68 \\
\hline VO-2745 & Point Lay & 69.0033 & 163.7531 & Corwin & 0.74 \\
\hline VO-2747 & Point Lay & 69.0050 & 163.8397 & Corwin & 0.74 \\
\hline VO-2748 & Point Lay & 69.0050 & 163.8436 & Corwin & 0.73 \\
\hline VO-2750 & Point Lay & 69.0083 & 163.7944 & Corwin & 0.74 \\
\hline VO-2751 & Point Lay & 69.0086 & 163.7833 & Corwin & 0.74 \\
\hline VO-2753 & Point Lay & 69.0119 & 163.8414 & Corwin & 0.70 \\
\hline VO-2762 & Point Lay & 69.0181 & 163.8383 & Nanushuk Gp & 0.65 \\
\hline VO-2763 & Point Lay & 69.0192 & 163.8792 & Nanushuk Gp & 0.73 \\
\hline VO-2764 & Point Lay & 69.0211 & 163.8414 & Corwin & 0.72 \\
\hline VO-2767 & Point Lay & 69.0217 & 163.8397 & Corwin & 0.74 \\
\hline VO-2769 & Point Lay & 69.0236 & 163.8792 & Nanushuk Gp & 0.74 \\
\hline VO-2770 & Point Lay & 69.0242 & 162.9167 & Torok & 0.86 \\
\hline VO-2771 & Point Lay & 69.0797 & 162.5567 & Nanushuk Gp & 0.80 \\
\hline VO-2774 & Point Lay & 69.0831 & 162.5503 & Nanushuk Gp & 0.75 \\
\hline VO-2775 & Point Lay & 69.0831 & 162.5692 & Nanushuk Gp & 0.79 \\
\hline VO-2777 & Point Lay & 69.1056 & 163.3931 & Nanushuk Gp & 0.70 \\
\hline VO-2782 & Point Lay & 69.1067 & 162.5597 & Nanushuk Gp & 0.79 \\
\hline VO-2783 & Point Lay & 69.1072 & 162.7700 & Kukpowruk & 0.87 \\
\hline VO-2784 & Point Lay & 69.1036 & 162.7689 & Kukpowruk & 0.87 \\
\hline VO-2785 & Point Lay & 69.1167 & 162.5725 & Nanushuk Gp & 0.74 \\
\hline VO-2786 & Point Lay & 69.1233 & 162.5819 & Nanushuk Gp & 0.70 \\
\hline VO-2787 & Point Lay & 69.1256 & 162.6258 & Nanushuk Gp & 0.69 \\
\hline VO-2788 & Point Lay & 69.1303 & 163.3836 & Nanushuk Gp & 0.71 \\
\hline VO-2789 & Point Lay & 69.1336 & 162.6356 & Nanushuk Gp & 0.70 \\
\hline VO-2790 & Point Lay & 69.1381 & 163.3833 & Nanushuk Gp & 0.64 \\
\hline VO-2791 & Point Lay & 69.1481 & 163.1231 & Nanushuk Gp & 0.68 \\
\hline VO-2793 & Point Lay & 69.1581 & 163.1544 & Nanushuk Gp & 0.62 \\
\hline VO-2794 & Point Lay & 69.1619 & 163.1831 & Nanushuk Gp & 0.67 \\
\hline VO-2797 & Point Lay & 69.1672 & 163.1642 & Nanushuk Gp & 0.72 \\
\hline
\end{tabular}


Table 8a. Vitrinite reflectance values of coals across the surface in the Northern AlaskaSlope, Central Alaska-Nenana, and Southern Alaska-Cook Inlet coal provinces. - Continued

\begin{tabular}{|c|c|c|c|c|c|}
\hline $\begin{array}{l}\text { Record } \\
\text { number }\end{array}$ & $\begin{array}{c}\text { Quadrangle scale } \\
\text { of } 1: 250,000\end{array}$ & $\begin{array}{l}\text { North } \\
\text { latitude }\end{array}$ & $\begin{array}{c}\text { West } \\
\text { longitude }\end{array}$ & Formation & $\begin{array}{l}\text { Mean } \\
\mathrm{R}_{0}(\%) \\
\end{array}$ \\
\hline VO-2798 & Point Lay & 69.1683 & 163.1989 & Nanushuk Gp & 0.71 \\
\hline VO-2799 & Point Lay & 69.1706 & 163.2272 & Nanushuk Gp & 0.68 \\
\hline VO-2800 & Point Lay & 69.1750 & 163.2842 & Nanushuk Gp & 0.73 \\
\hline VO-2801 & Point Lay & 69.1761 & 163.1294 & Nanushuk Gp & 0.73 \\
\hline VO-2804 & Point Lay & 69.1761 & 163.1956 & Nanushuk Gp & 0.61 \\
\hline VO-2805 & Point Lay & 69.2397 & 162.6661 & Corwin & 0.80 \\
\hline VO-2806 & Point Lay & 69.2419 & 162.6700 & Unnamed & 0.78 \\
\hline VO-2807 & Point Lay & 69.2428 & 162.6739 & Unnamed & 0.81 \\
\hline VO-2808 & Point Lay & 69.2456 & 162.6800 & Unnamed & 0.86 \\
\hline VO-2809 & Point Lay & 69.2464 & 162.6811 & Unnamed & 0.89 \\
\hline VO-2810 & Point Lay & 69.2478 & 162.6861 & Unnamed & 0.94 \\
\hline VO-2811 & Point Lay & 69.2486 & 162.6861 & Kukpowruk & 0.92 \\
\hline VO-2812 & Point Lay & 69.2517 & 162.7086 & Torok & 0.67 \\
\hline VO-2813 & Point Lay & 69.2611 & 162.7836 & Unnamed & 0.76 \\
\hline VO-2814 & Point Lay & 69.2594 & 162.7761 & Unnamed & 0.73 \\
\hline VO-2815 & Point Lay & 69.2594 & 162.7733 & Unnamed & 0.69 \\
\hline VO-2816 & Point Lay & 69.2581 & 162.7647 & Unnamed & 0.84 \\
\hline VO-2817 & Point Lay & 69.2533 & 162.7564 & Unnamed & 0.76 \\
\hline VO-2818 & Point Lay & 69.2517 & 162.7522 & Unnamed & 0.72 \\
\hline VO-2819 & Point Lay & 69.2578 & 162.7278 & Unnamed & 0.75 \\
\hline VO-2820 & Point Lay & 69.2525 & 162.7128 & Unnamed & 0.68 \\
\hline VO-2821 & Point Lay & 69.2519 & 162.7097 & Unnamed & 0.67 \\
\hline VO-2822 & Point Lay & 69.3611 & 162.0889 & Nanushuk Gp & 0.71 \\
\hline VO-2823 & Point Lay & 69.3914 & 162.6514 & Corwin & 0.63 \\
\hline VO-2824 & Point Lay & 69.3956 & 162.6589 & Corwin & 0.64 \\
\hline VO-2825 & Point Lay & 69.3933 & 162.6558 & Corwin & 0.64 \\
\hline VO-2826 & Point Lay & 69.3922 & 162.6542 & Corwin & 0.63 \\
\hline VO-2827 & Point Lay & 69.4128 & 162.6828 & Kukpowruk & 0.79 \\
\hline VO-2828 & Point Lay & 69.4183 & 162.6939 & Unnamed & 0.70 \\
\hline VO-2829 & Point Lay & 69.4169 & 162.6928 & Unnamed & 0.72 \\
\hline VO-2830 & Point Lay & 69.4161 & 162.6919 & Unnamed & 0.72 \\
\hline VO-2831 & Point Lay & 69.4150 & 162.6903 & Unnamed & 0.75 \\
\hline VO-2832 & Point Lay & 69.4144 & 162.6889 & Unnamed & 0.70 \\
\hline VO-2833 & Point Lay & 69.4136 & 162.6867 & Unnamed & 0.63 \\
\hline VO-2834 & Point Lay & 69.4133 & 162.6844 & Unnamed & 0.77 \\
\hline VO-2835 & Point Lay & 69.5156 & 162.7692 & Corwin & 0.53 \\
\hline VO-3011 & Sagavanirktok & 69.0125 & 148.8094 & Nanushuk Gp & 0.86 \\
\hline VO-3012 & Sagavanirktok & 69.0217 & 148.8364 & Nanushuk Gp & 0.60 \\
\hline VO-3013 & Sagavanirktok & 69.0389 & 148.1131 & Nanushuk Gp. & 1.34 \\
\hline VO-3015 & Sagavanirktok & 69.0925 & 148.7683 & Unnamed & 0.64 \\
\hline VO-3016 & Sagavanirktok & 69.0928 & 148.7703 & Unnamed & 0.74 \\
\hline VO-3017 & Sagavanirktok & 69.0936 & 148.7739 & Unnamed & 0.70 \\
\hline VO-3018 & Sagavanirktok & 69.0928 & 148.7719 & Nanushuk Gp & 0.68 \\
\hline VO-3019 & Sagavanirktok & 69.0942 & 148.7792 & Nanushuk Gp & 0.84 \\
\hline
\end{tabular}


Table 8a. Vitrinite reflectance values of coals across the surface in the Northern AlaskaSlope, Central Alaska-Nenana, and Southern Alaska-Cook Inlet coal provinces. - Continued

\begin{tabular}{|c|c|c|c|c|c|}
\hline $\begin{array}{l}\text { Record } \\
\text { number }\end{array}$ & $\begin{array}{c}\text { Quadrangle scale } \\
\text { of } 1: 250,000\end{array}$ & $\begin{array}{c}\text { North } \\
\text { latitude }\end{array}$ & $\begin{array}{c}\text { West } \\
\text { longitude }\end{array}$ & Formation & $\begin{array}{l}\text { Mean } \\
\mathbf{R}_{0}(\%)\end{array}$ \\
\hline VO-3020 & Sagavanirktok & 69.0983 & 148.0058 & Nanushuk Gp & 1.87 \\
\hline VO-3023 & Sagavanirktok & 69.1617 & 147.7833 & Unnamed & 0.76 \\
\hline VO-3028 & Sagavanirktok & 69.1850 & 148.5386 & Unnamed & 0.41 \\
\hline VO-3032 & Sagavanirktok & 69.3119 & 147.6728 & Unnamed & 1.35 \\
\hline VO-3035 & Sagavanirktok & 69.3161 & 147.7036 & Torok & 1.69 \\
\hline VO-3036 & Sagavanirktok & 69.3217 & 148.6719 & Unnamed & 0.34 \\
\hline VO-3038 & Sagavanirktok & 69.3430 & 147.2039 & Unnamed & 1.50 \\
\hline VO-3040 & Sagavanirktok & 69.3642 & 147.1233 & Unnamed & 1.16 \\
\hline VO-3041 & Sagavanirktok & 69.3647 & 147.1233 & Unnamed & 0.95 \\
\hline VO-3042 & Sagavanirktok & 69.3653 & 147.1233 & Unnamed & 0.95 \\
\hline VO-3043 & Sagavanirktok & 69.3828 & 148.7147 & Sagavanirktok & 0.37 \\
\hline VO-3046 & Sagavanirktok & 69.3906 & 147.1430 & Unnamed & 1.15 \\
\hline VO-3047 & Sagavanirktok & 69.3925 & 147.1453 & Unnamed & 1.24 \\
\hline VO-3048 & Sagavanirktok & 69.4033 & 148.6758 & Sagavanirktok & 0.39 \\
\hline VO-3058 & Sagavanirktok & 69.4336 & 148.5233 & Sagavanirktok & 0.46 \\
\hline VO-3060 & Sagavanirktok & 69.5583 & 147.0833 & Unnamed & 0.34 \\
\hline VO-3062 & Sagavanirktok & 69.5592 & 146.5250 & Unnamed & 0.62 \\
\hline VO-3064 & Sagavanirktok & 69.5833 & 147.7933 & Sagavanirktok & 0.32 \\
\hline VO-3075 & Sagavanirktok & 69.9667 & 148.8017 & Unnamed & 0.60 \\
\hline VO-3086 & Seldovia & 59.3700 & 151.3650 & Unnamed & 1.97 \\
\hline VO-3089 & Seldovia & 59.3980 & 151.8980 & Kenai & 0.44 \\
\hline VO-3092 & Seldovia & 59.4750 & 151.6700 & Kenai & 0.32 \\
\hline VO-3094 & Seldovia & 59.6430 & 151.5820 & Beluga & 0.22 \\
\hline VO-3095 & Seldovia & 59.7080 & 151.4580 & Sterling & 0.27 \\
\hline VO-3100 & Seldovia & 59.7150 & 151.8080 & Kenai & 0.38 \\
\hline VO-3101 & Seldovia & 59.7180 & 151.2420 & Beluga & 0.28 \\
\hline VO-3106 & Seldovia & 59.7320 & 151.2170 & Kenai & 0.31 \\
\hline VO-3117 & Seldovia & 59.8770 & 152.9820 & Unnamed & 0.46 \\
\hline VO-3118 & Seldovia & 59.9300 & 151.7450 & Beluga & 0.24 \\
\hline VO-3202 & Talkeetna & 62.0558 & 151.9050 & Kenai Gp & 0.37 \\
\hline VO-3219 & Talkeetna Mountains & 62.0530 & 149.7350 & Kenai & 0.25 \\
\hline VO-3289 & Tyonek & 61.0317 & 151.3075 & Kenai Gp & 0.45 \\
\hline VO-3290 & Tyonek & 61.1203 & 151.3156 & Kenai Gp & 0.36 \\
\hline VO-3292 & Tyonek & 61.1544 & 151.4872 & Kenai Gp & 0.42 \\
\hline VO-3293 & Tyonek & 61.1564 & 151.5086 & Kenai Gp & 0.38 \\
\hline VO-3294 & Tyonek & 61.1610 & 151.5190 & Kenai & 0.33 \\
\hline VO-3295 & Tyonek & 61.1844 & 151.6272 & Kenai Gp & 0.37 \\
\hline VO-3296 & Tyonek & 61.1880 & 152.8430 & Unnamed & 0.18 \\
\hline VO-3297 & Tyonek & 61.1883 & 151.5922 & Kenai Gp & 0.39 \\
\hline VO-3298 & Tyonek & 61.2030 & 151.5200 & Beluga & 0.18 \\
\hline VO-3299 & Tyonek & 61.2128 & 151.1842 & Kenai Gp & 0.34 \\
\hline VO-3304 & Tyonek & 61.2806 & 151.7708 & Kenai Gp & 0.38 \\
\hline VO-3311 & Tyonek & 61.2880 & 151.7370 & Tyonek & 0.24 \\
\hline VO-3312 & Tyonek & 61.2992 & 151.7175 & Kenai Gp & 0.36 \\
\hline
\end{tabular}


Table 8a. Vitrinite reflectance values of coals across the surface in the Northern AlaskaSlope, Central Alaska-Nenana, and Southern Alaska-Cook Inlet coal provinces.

- Continued

\begin{tabular}{|c|c|c|c|c|c|}
\hline $\begin{array}{l}\text { Record } \\
\text { number }\end{array}$ & $\begin{array}{c}\text { Quadrangle scale } \\
\text { of } 1: 250,000\end{array}$ & $\begin{array}{l}\text { North } \\
\text { latitude }\end{array}$ & $\begin{array}{c}\text { West } \\
\text { longitude }\end{array}$ & Formation & $\begin{array}{l}\text { Mean } \\
\mathbf{R}_{0}(\%)\end{array}$ \\
\hline VO-3313 & Tyonek & 61.3019 & 151.7583 & Kenai Gp & 0.41 \\
\hline VO-3314 & Tyonek & 61.4044 & 151.3806 & Kenai Gp & 0.38 \\
\hline VO-3316 & Tyonek & 61.4200 & 151.5230 & Kenai & 0.33 \\
\hline VO-3317 & Tyonek & 61.4270 & 151.5830 & Kenai & 0.33 \\
\hline VO-3318 & Tyonek & 61.4361 & 151.5106 & Kenai Gp & 0.36 \\
\hline VO-3320 & Tyonek & 61.5542 & 150.8344 & Kenai Gp & 0.41 \\
\hline VO-3324 & Tyonek & 61.5867 & 150.8281 & Kenai Gp & 0.37 \\
\hline VO-3326 & Tyonek & 61.5920 & 150.8200 & Kenai & 0.38 \\
\hline VO-3327 & Tyonek & 61.6783 & 151.5700 & Kenai Gp & 0.38 \\
\hline VO-3328 & Tyonek & 61.6797 & 151.5767 & Kenai Gp & 0.38 \\
\hline VO-3329 & Tyonek & 61.6814 & 151.5842 & Kenai Gp & 0.34 \\
\hline VO-3333 & Tyonek & 61.6933 & 151.5867 & Kenai Gp & 0.38 \\
\hline VO-3334 & Tyonek & 61.7183 & 151.4525 & Kenai Gp & 0.44 \\
\hline VO-3335 & Tyonek & 61.7558 & 151.7025 & Kenai Gp & 0.33 \\
\hline VO-3346 & Tyonek & 61.7575 & 151.7039 & Kenai Gp & 0.34 \\
\hline VO-3352 & Tyonek & 61.7656 & 151.6869 & Kenai Gp & 0.39 \\
\hline VO-3353 & Tyonek & 61.7783 & 151.7572 & Kenai Gp & 0.34 \\
\hline VO-3354 & Tyonek & 61.7930 & 150.7300 & Kenai & 0.22 \\
\hline VO-3355 & Tyonek & 61.8014 & 151.6933 & Kenai Gp & 0.34 \\
\hline VO-3356 & Tyonek & 61.8028 & 151.7100 & Kenai Gp & 0.31 \\
\hline VO-3357 & Tyonek & 61.9783 & 151.9575 & Kenai Gp & 0.35 \\
\hline VO-3375 & Umiat & 69.0356 & 150.8853 & Shale Wall Mbr & 0.46 \\
\hline VO-3376 & Umiat & 69.0703 & 150.8458 & Ayiyak Mbr & 0.47 \\
\hline VO-3377 & Umiat & 69.0625 & 150.8586 & Unnamed & 0.45 \\
\hline VO-3378 & Umiat & 69.0578 & 150.8675 & Unnamed & 0.56 \\
\hline VO-3379 & Umiat & 69.0544 & 150.8725 & Unnamed & 0.55 \\
\hline VO-3380 & Umiat & 69.0503 & 150.8792 & Unnamed & 0.49 \\
\hline VO-3381 & Umiat & 69.0431 & 150.8886 & Unnamed & 0.45 \\
\hline VO-3382 & Umiat & 69.0400 & 150.8875 & Unnamed & 0.45 \\
\hline VO-3383 & Umiat & 69.1564 & 151.0178 & Schrader Bluff & 0.45 \\
\hline VO-3386 & Umiat & 69.1575 & 151.0178 & Schrader Bluff & 0.50 \\
\hline VO-3387 & Umiat & 69.1597 & 151.0181 & Schrader Bluff & 0.52 \\
\hline VO-3388 & Umiat & 69.1614 & 151.0197 & Schrader Bluff & 0.51 \\
\hline VO-3389 & Umiat & 69.2994 & 152.7381 & Colville Gp & 0.68 \\
\hline VO-3390 & Umiat & 69.3792 & 152.5250 & Shale Wall Mbr & 0.51 \\
\hline VO-3391 & Umiat & 69.4081 & 151.8414 & Schrader Bluff & 0.31 \\
\hline VO-3392 & Umiat & 69.4258 & 151.6181 & Schrader Bluff & 0.37 \\
\hline VO-3393 & Umiat & 69.4306 & 151.7267 & Schrader Bluff & 0.45 \\
\hline VO-3394 & Umiat & 69.5000 & 151.4903 & Prince Creek & 0.37 \\
\hline VO-3395 & Umiat & 69.5044 & 151.4808 & Prince Creek & 0.39 \\
\hline VO-3396 & Umiat & 69.6325 & 151.4550 & Prince Creek & 0.37 \\
\hline VO-3397 & Umiat & 69.9944 & 151.6083 & Prince Creek & 0.40 \\
\hline VO-3427 & Utukok River & 69.0717 & 161.4622 & Nanushuk Gp & 0.78 \\
\hline VO-3429 & Utukok River & 69.0750 & 161.2989 & Nanushuk Gp & 0.85 \\
\hline
\end{tabular}


Table 8a. Vitrinite reflectance values of coals across the surface in the Northern AlaskaSlope, Central Alaska-Nenana, and Southern Alaska-Cook Inlet coal provinces. - Continued

\begin{tabular}{|c|c|c|c|c|c|}
\hline $\begin{array}{l}\text { Record } \\
\text { number }\end{array}$ & $\begin{array}{c}\text { Quadrangle scale } \\
\text { of } 1: 250,000\end{array}$ & $\begin{array}{l}\text { North } \\
\text { latitude }\end{array}$ & $\begin{array}{c}\text { West } \\
\text { longitude }\end{array}$ & Formation & $\begin{array}{l}\text { Mean } \\
\mathbf{R}_{0}(\%) \\
\end{array}$ \\
\hline VO-3430 & Utukok River & 69.0839 & 161.2925 & Nanushuk Gp & 0.77 \\
\hline VO-3431 & Utukok River & 69.0975 & 161.4244 & Nanushuk Gp & 0.89 \\
\hline VO-3432 & Utukok River & 69.0997 & 161.3397 & Nanushuk Gp & 0.71 \\
\hline VO-3433 & Utukok River & 69.0997 & 161.3806 & Nanushuk Gp & 0.80 \\
\hline VO-3434 & Utukok River & 69.1008 & 161.5031 & Nanushuk Gp & 0.72 \\
\hline VO-3435 & Utukok River & 69.1019 & 161.5756 & Nanushuk Gp & 0.72 \\
\hline VO-3436 & Utukok River & 69.1067 & 161.4217 & Corwin & 0.68 \\
\hline VO-3437 & Utukok River & 69.1167 & 161.4267 & Corwin & 0.64 \\
\hline VO-3438 & Utukok River & 69.1381 & 161.4231 & Corwin & 0.67 \\
\hline VO-3439 & Utukok River & 69.1431 & 161.4242 & Corwin & 0.70 \\
\hline VO-3440 & Utukok River & 69.1494 & 161.4167 & Corwin & 0.77 \\
\hline VO-3441 & Utukok River & 69.1550 & 161.4164 & Corwin & 0.80 \\
\hline VO-3442 & Utukok River & 69.1594 & 161.4161 & Corwin & 0.72 \\
\hline VO-3443 & Utukok River & 69.1617 & 161.4158 & Corwin & 0.68 \\
\hline VO-3444 & Utukok River & 69.1625 & 161.5847 & Corwin & 0.77 \\
\hline VO-3445 & Utukok River & 69.1064 & 161.5756 & Nanushuk Gp & 0.72 \\
\hline VO-3446 & Utukok River & 69.1097 & 161.4025 & Nanushuk Gp & 0.78 \\
\hline VO-3447 & Utukok River & 69.1131 & 161.4214 & Nanushuk Gp & 0.85 \\
\hline VO-3450 & Utukok River & 69.1142 & 161.5472 & Nanushuk Gp & 0.74 \\
\hline VO-3451 & Utukok River & 69.1153 & 161.4686 & Nanushuk Gp & 0.86 \\
\hline VO-3452 & Utukok River & 69.1153 & 161.5064 & Nanushuk Gp & 0.78 \\
\hline VO-3453 & Utukok River & 69.1233 & 161.3708 & Nanushuk Gp & 0.86 \\
\hline VO-3454 & Utukok River & 69.1250 & 159.6083 & Corwin & 0.62 \\
\hline VO-3455 & Utukok River & 69.1319 & 159.6653 & Unnamed & 0.64 \\
\hline VO-3456 & Utukok River & 69.1389 & 159.6778 & Unnamed & 0.62 \\
\hline VO-3457 & Utukok River & 69.1411 & 159.6806 & Unnamed & 0.53 \\
\hline VO-3458 & Utukok River & 69.1431 & 159.6889 & Unnamed & 0.62 \\
\hline VO-3459 & Utukok River & 69.1267 & 161.4181 & Nanushuk Gp & 0.83 \\
\hline VO-3460 & Utukok River & 69.1619 & 160.5517 & Unnamed & 0.63 \\
\hline VO-3461 & Utukok River & 69.1683 & 160.6439 & Unnamed & 0.82 \\
\hline VO-3462 & Utukok River & 69.1753 & 160.6444 & Unnamed & 0.83 \\
\hline VO-3463 & Utukok River & 69.1403 & 161.8842 & Corwin & 0.64 \\
\hline VO-3464 & Utukok River & 69.1431 & 161.8850 & Unnamed & 0.63 \\
\hline VO-3465 & Utukok River & 69.1528 & 161.8808 & Unnamed & 0.70 \\
\hline VO-3466 & Utukok River & 69.1592 & 161.8828 & Unnamed & 0.87 \\
\hline VO-3467 & Utukok River & 69.1611 & 161.8833 & Unnamed & 0.89 \\
\hline VO-3468 & Utukok River & 69.1697 & 161.8844 & Unnamed & 0.96 \\
\hline VO-3469 & Utukok River & 69.1444 & 159.6917 & Torok & 0.57 \\
\hline VO-3470 & Utukok River & 69.1489 & 160.7333 & Nanushuk Gp & 0.84 \\
\hline VO-3471 & Utukok River & 69.1650 & 161.5847 & Torok & 0.82 \\
\hline VO-3472 & Utukok River & 69.1731 & 161.8850 & Torok & 0.94 \\
\hline VO-3473 & Utukok River & 69.1747 & 160.7272 & Nanushuk Gp & 0.96 \\
\hline VO-3474 & Utukok River & 69.1786 & 160.6411 & Torok & 0.88 \\
\hline VO-3475 & Utukok River & 69.2472 & 159.4972 & Corwin & 0.80 \\
\hline
\end{tabular}


Table 8a. Vitrinite reflectance values of coals across the surface in the Northern AlaskaSlope, Central Alaska-Nenana, and Southern Alaska-Cook Inlet coal provinces.

- Continued

\begin{tabular}{|c|c|c|c|c|c|}
\hline $\begin{array}{l}\text { Record } \\
\text { number }\end{array}$ & $\begin{array}{c}\text { Quadrangle scale } \\
\text { of } 1: 250,000\end{array}$ & $\begin{array}{l}\text { North } \\
\text { latitude }\end{array}$ & $\begin{array}{c}\text { West } \\
\text { longitude }\end{array}$ & Formation & $\begin{array}{l}\text { Mean } \\
\mathbf{R}_{0}(\%) \\
\end{array}$ \\
\hline VO-3476 & Utukok River & 69.2500 & 159.4964 & Unnamed & 0.70 \\
\hline VO-3477 & Utukok River & 69.2542 & 159.4958 & Unnamed & 0.72 \\
\hline VO-3478 & Utukok River & 69.2611 & 159.5472 & Unnamed & 0.73 \\
\hline VO-3479 & Utukok River & 69.2625 & 159.5444 & Unnamed & 0.65 \\
\hline VO-3480 & Utukok River & 69.2664 & 159.5389 & Unnamed & 0.70 \\
\hline VO-3481 & Utukok River & 69.2722 & 159.5325 & Unnamed & 0.69 \\
\hline VO-3482 & Utukok River & 69.2897 & 159.5222 & Unnamed & 0.51 \\
\hline VO-3483 & Utukok River & 69.2622 & 160.5919 & Nanushuk Gp & 0.76 \\
\hline VO-3484 & Utukok River & 69.2656 & 160.5856 & Nanushuk Gp & 0.76 \\
\hline VO-3485 & Utukok River & 69.2811 & 160.5761 & Nanushuk Gp & 0.74 \\
\hline VO-3486 & Utukok River & 69.2881 & 159.0128 & Nanushuk Gp & 0.70 \\
\hline VO-3487 & Utukok River & 69.2881 & 161.1744 & Nanushuk Gp & 0.77 \\
\hline VO-3488 & Utukok River & 69.2950 & 161.1078 & Nanushuk Gp & 0.75 \\
\hline VO-3489 & Utukok River & 69.2972 & 159.5111 & Torok & 0.72 \\
\hline VO-3490 & Utukok River & 69.2972 & 161.1808 & Nanushuk Gp & 0.80 \\
\hline VO-3491 & Utukok River & 69.3039 & 159.1428 & Nanushuk Gp & 0.72 \\
\hline VO-3492 & Utukok River & 69.3058 & 160.4842 & Nanushuk Gp & 0.69 \\
\hline VO-3493 & Utukok River & 69.3092 & 160.4808 & Nanushuk Gp & 0.68 \\
\hline VO-3494 & Utukok River & 69.3161 & 160.2428 & Nanushuk Gp & 0.60 \\
\hline VO-3495 & Utukok River & 69.3172 & 161.1525 & Nanushuk Gp & 0.77 \\
\hline VO-3496 & Utukok River & 69.3250 & 161.9544 & Nanushuk Gp & 0.76 \\
\hline VO-3497 & Utukok River & 69.3353 & 159.3600 & Nanushuk Gp & 0.79 \\
\hline VO-3498 & Utukok River & 69.3361 & 160.4683 & Nanushuk Gp & 0.72 \\
\hline VO-3499 & Utukok River & 69.3361 & 160.5000 & Nanushuk Gp & 0.68 \\
\hline VO-3502 & Utukok River & 69.3372 & 160.4269 & Nanushuk Gp & 0.80 \\
\hline VO-3503 & Utukok River & 69.3394 & 160.5636 & Nanushuk Gp & 0.65 \\
\hline VO-3504 & Utukok River & 69.3453 & 160.4586 & Nanushuk Gp & 0.70 \\
\hline VO-3505 & Utukok River & 69.3453 & 160.5572 & Nanushuk Gp & 0.74 \\
\hline VO-3506 & Utukok River & 69.3486 & 160.5508 & Nanushuk Gp & 0.72 \\
\hline VO-3507 & Utukok River & 69.3508 & 160.5508 & Nanushuk Gp & 0.69 \\
\hline VO-3508 & Utukok River & 69.3519 & 160.5892 & Nanushuk Gp & 0.72 \\
\hline VO-3514 & Utukok River & 69.3542 & 160.5444 & Nanushuk Gp & 0.69 \\
\hline VO-3515 & Utukok River & 69.3542 & 160.6369 & Nanushuk Gp & 0.74 \\
\hline VO-3520 & Utukok River & 69.3542 & 160.6622 & Nanushuk Gp & 0.74 \\
\hline VO-3521 & Utukok River & 69.3564 & 160.3092 & Nanushuk Gp & 0.76 \\
\hline VO-3522 & Utukok River & 69.3575 & 160.7036 & Nanushuk Gp & 0.75 \\
\hline VO-3523 & Utukok River & 69.3586 & 160.5414 & Nanushuk Gp & 0.68 \\
\hline VO-3524 & Utukok River & 69.3589 & 161.4236 & Nanushuk Gp & 0.72 \\
\hline VO-3525 & Utukok River & 69.3608 & 160.4172 & Nanushuk Gp & 0.78 \\
\hline VO-3526 & Utukok River & 69.3608 & 160.5350 & Nanushuk Gp & 0.66 \\
\hline VO-3527 & Utukok River & 69.3611 & 161.2006 & Nanushuk Gp & 0.69 \\
\hline VO-3528 & Utukok River & 69.3611 & 161.2581 & Nanushuk Gp & 0.63 \\
\hline VO-3529 & Utukok River & 69.3611 & 161.4681 & Nanushuk Gp & 0.96 \\
\hline VO-3530 & Utukok River & 69.3611 & 161.5128 & Nanushuk Gp & 0.70 \\
\hline
\end{tabular}


Table 8a. Vitrinite reflectance values of coals across the surface in the Northern AlaskaSlope, Central Alaska-Nenana, and Southern Alaska-Cook Inlet coal provinces. - Continued

\begin{tabular}{|c|c|c|c|c|c|}
\hline $\begin{array}{l}\text { Record } \\
\text { number }\end{array}$ & $\begin{array}{c}\text { Quadrangle scale } \\
\text { of } 1: 250,000\end{array}$ & $\begin{array}{c}\text { North } \\
\text { latitude }\end{array}$ & $\begin{array}{c}\text { West } \\
\text { longitude }\end{array}$ & Formation & $\begin{array}{l}\text { Mean } \\
\mathbf{R}_{0}(\%) \\
\end{array}$ \\
\hline VO-3531 & Utukok River & 69.3611 & 161.5256 & Nanushuk Gp & 0.75 \\
\hline VO-3532 & Utukok River & 69.3611 & 161.5444 & Nanushuk Gp & 0.75 \\
\hline VO-3533 & Utukok River & 69.3611 & 161.5508 & Nanushuk Gp & 0.79 \\
\hline VO-3534 & Utukok River & 69.3622 & 161.4300 & Nanushuk Gp & 0.72 \\
\hline VO-3535 & Utukok River & 69.3622 & 161.4744 & Nanushuk Gp & 0.75 \\
\hline VO-3536 & Utukok River & 69.3633 & 161.3344 & Nanushuk Gp & 0.76 \\
\hline VO-3537 & Utukok River & 69.3633 & 161.3631 & Nanushuk Gp & 0.71 \\
\hline VO-3538 & Utukok River & 69.3633 & 161.4394 & Nanushuk Gp & 0.75 \\
\hline VO-3539 & Utukok River & 69.3633 & 161.4556 & Nanushuk Gp & 0.70 \\
\hline VO-3540 & Utukok River & 69.3642 & 160.3567 & Nanushuk Gp & 0.73 \\
\hline VO-3541 & Utukok River & 69.3642 & 160.7706 & Nanushuk Gp & 0.72 \\
\hline VO-3542 & Utukok River & 69.3644 & 161.0256 & Nanushuk Gp & 0.86 \\
\hline VO-3543 & Utukok River & 69.3644 & 161.2900 & Nanushuk Gp & 0.77 \\
\hline VO-3544 & Utukok River & 69.3644 & 161.2994 & Nanushuk Gp & 0.73 \\
\hline VO-3545 & Utukok River & 69.3644 & 161.3853 & Nanushuk Gp & 0.82 \\
\hline VO-3546 & Utukok River & 69.3644 & 161.3981 & Nanushuk Gp & 0.77 \\
\hline VO-3547 & Utukok River & 69.3653 & 160.5286 & Nanushuk Gp & 0.76 \\
\hline VO-3548 & Utukok River & 69.3656 & 161.0733 & Nanushuk Gp & 0.77 \\
\hline VO-3549 & Utukok River & 69.3656 & 161.2453 & Nanushuk Gp & 0.81 \\
\hline VO-3550 & Utukok River & 69.3656 & 161.2708 & Nanushuk Gp & 0.75 \\
\hline VO-3551 & Utukok River & 69.3697 & 160.5094 & Nanushuk Gp & 0.72 \\
\hline VO-3552 & Utukok River & 69.3697 & 160.5158 & Nanushuk Gp & 0.66 \\
\hline VO-3553 & Utukok River & 69.3700 & 161.2039 & Nanushuk Gp & 0.78 \\
\hline VO-3554 & Utukok River & 69.3733 & 160.5128 & Nanushuk Gp & 0.80 \\
\hline VO-3555 & Utukok River & 69.3733 & 161.0256 & Nanushuk Gp & 0.58 \\
\hline VO-3556 & Utukok River & 69.3733 & 161.2039 & Nanushuk Gp & 0.78 \\
\hline VO-3557 & Utukok River & 69.3744 & 161.2611 & Nanushuk Gp & 0.59 \\
\hline VO-3558 & Utukok River & 69.3756 & 161.3886 & Nanushuk Gp & 0.73 \\
\hline VO-3559 & Utukok River & 69.3767 & 159.8344 & Nanushuk Gp & 0.71 \\
\hline VO-3560 & Utukok River & 69.3767 & 160.5064 & Nanushuk Gp & 0.74 \\
\hline VO-3561 & Utukok River & 69.3811 & 160.7611 & Nanushuk Gp & 0.76 \\
\hline VO-3562 & Utukok River & 69.3814 & 161.2486 & Nanushuk Gp & 0.78 \\
\hline VO-3563 & Utukok River & 69.3844 & 159.7897 & Nanushuk Gp & 0.79 \\
\hline VO-3564 & Utukok River & 69.3878 & 160.4906 & Nanushuk Gp & 0.68 \\
\hline VO-3565 & Utukok River & 69.3892 & 161.0700 & Nanushuk Gp & 0.57 \\
\hline VO-3566 & Utukok River & 69.3892 & 161.1147 & Nanushuk Gp & 0.72 \\
\hline VO-3567 & Utukok River & 69.3892 & 161.2072 & Nanushuk Gp & 0.81 \\
\hline VO-3568 & Utukok River & 69.3892 & 161.2578 & Nanushuk Gp & 0.69 \\
\hline VO-3569 & Utukok River & 69.3989 & 160.5192 & Nanushuk Gp & 0.63 \\
\hline VO-3570 & Utukok River & 69.4036 & 161.0447 & Nanushuk Gp & 0.69 \\
\hline VO-3571 & Utukok River & 69.4047 & 160.4969 & Nanushuk Gp & 0.65 \\
\hline VO-3572 & Utukok River & 69.4047 & 160.6083 & Nanushuk Gp & 0.79 \\
\hline VO-3573 & Utukok River & 69.4058 & 161.2894 & Nanushuk Gp & 0.74 \\
\hline VO-3574 & Utukok River & 69.4069 & 160.4553 & Nanushuk Gp & 0.68 \\
\hline
\end{tabular}


Table 8a. Vitrinite reflectance values of coals across the surface in the Northern AlaskaSlope, Central Alaska-Nenana, and Southern Alaska-Cook Inlet coal provinces. - Continued

\begin{tabular}{|c|c|c|c|c|c|}
\hline $\begin{array}{l}\text { Record } \\
\text { number }\end{array}$ & $\begin{array}{c}\text { Quadrangle scale } \\
\text { of } 1: 250,000\end{array}$ & $\begin{array}{l}\text { North } \\
\text { latitude }\end{array}$ & $\begin{array}{c}\text { West } \\
\text { longitude }\end{array}$ & Formation & $\begin{array}{l}\text { Mean } \\
\mathbf{R}_{0}(\%)\end{array}$ \\
\hline VO-3575 & Utukok River & 69.4081 & 160.3853 & Nanushuk Gp & 0.72 \\
\hline VO-3576 & Utukok River & 69.4081 & 160.4425 & Nanushuk Gp & 0.71 \\
\hline VO-3577 & Utukok River & 69.4081 & 160.7297 & Nanushuk Gp & 0.70 \\
\hline VO-3578 & Utukok River & 69.4114 & 160.4489 & Nanushuk Gp & 0.68 \\
\hline VO-3579 & Utukok River & 69.4136 & 160.4969 & Nanushuk Gp & 0.72 \\
\hline VO-3580 & Utukok River & 69.4158 & 160.4489 & Nanushuk Gp & 0.74 \\
\hline VO-3581 & Utukok River & 69.4169 & 160.7361 & Nanushuk Gp & 0.74 \\
\hline VO-3582 & Utukok River & 69.4183 & 161.2042 & Nanushuk Gp & 0.73 \\
\hline VO-3583 & Utukok River & 69.4206 & 161.1244 & Nanushuk Gp & 0.74 \\
\hline VO-3584 & Utukok River & 69.4214 & 160.7331 & Nanushuk Gp & 0.73 \\
\hline VO-3585 & Utukok River & 69.4258 & 160.7331 & Nanushuk Gp & 0.77 \\
\hline VO-3586 & Utukok River & 69.4269 & 159.5861 & Nanushuk Gp & 0.78 \\
\hline VO-3587 & Utukok River & 69.4283 & 159.7414 & Nanushuk Gp & 0.84 \\
\hline VO-3588 & Utukok River & 69.4283 & 160.2189 & Nanushuk Gp & 0.71 \\
\hline VO-3589 & Utukok River & 69.4283 & 161.8319 & Nanushuk Gp & 0.80 \\
\hline VO-3590 & Utukok River & 69.4339 & 160.2189 & Nanushuk Gp & 0.85 \\
\hline VO-3591 & Utukok River & 69.4406 & 161.9089 & Nanushuk Gp & 0.72 \\
\hline VO-3592 & Utukok River & 69.4450 & 160.5511 & Nanushuk Gp & 0.63 \\
\hline VO-3593 & Utukok River & 69.4461 & 160.5192 & Nanushuk Gp & 0.75 \\
\hline VO-3595 & Utukok River & 69.4528 & 160.3242 & Nanushuk Gp & 0.84 \\
\hline VO-3596 & Utukok River & 69.4550 & 160.3211 & Nanushuk Gp & 0.79 \\
\hline VO-3597 & Utukok River & 69.4575 & 160.3178 & Nanushuk Gp & 0.71 \\
\hline VO-3598 & Utukok River & 69.4619 & 160.3592 & Nanushuk Gp & 0.72 \\
\hline VO-3599 & Utukok River & 69.4619 & 160.7206 & Nanushuk Gp & 0.80 \\
\hline VO-3600 & Utukok River & 69.4653 & 160.7175 & Nanushuk Gp & 0.79 \\
\hline VO-3601 & Utukok River & 69.4664 & 160.6950 & Nanushuk Gp & 0.74 \\
\hline VO-3602 & Utukok River & 69.4675 & 160.3528 & Nanushuk Gp & 0.69 \\
\hline VO-3603 & Utukok River & 69.4697 & 160.7175 & Nanushuk Gp & 0.78 \\
\hline VO-3604 & Utukok River & 69.4753 & 160.3272 & Nanushuk Gp & 0.82 \\
\hline VO-3605 & Utukok River & 69.4753 & 160.3400 & Nanushuk Gp & 0.76 \\
\hline VO-3606 & Utukok River & 69.4867 & 161.8394 & Nanushuk Gp & 0.72 \\
\hline VO-3607 & Utukok River & 69.4933 & 161.8394 & Nanushuk Gp & 0.68 \\
\hline VO-3608 & Utukok River & 69.5000 & 160.0225 & Nanushuk Gp & 0.75 \\
\hline VO-3609 & Utukok River & 69.5158 & 161.2308 & Nanushuk Gp & 0.80 \\
\hline VO-3610 & Utukok River & 69.5192 & 160.6956 & Nanushuk Gp & 0.74 \\
\hline VO-3611 & Utukok River & 69.5225 & 159.1347 & Nanushuk Gp & 0.74 \\
\hline VO-3612 & Utukok River & 69.5247 & 160.6956 & Nanushuk Gp & 0.79 \\
\hline VO-3613 & Utukok River & 69.5325 & 159.5867 & Nanushuk Gp & 0.76 \\
\hline VO-3614 & Utukok River & 69.5336 & 161.2336 & Nanushuk Gp & 0.76 \\
\hline VO-3615 & Utukok River & 69.5347 & 159.1283 & Nanushuk Gp & 0.81 \\
\hline VO-3616 & Utukok River & 69.5381 & 160.2689 & Nanushuk Gp & 0.74 \\
\hline VO-3617 & Utukok River & 69.5483 & 160.3169 & Nanushuk Gp & 0.76 \\
\hline VO-3618 & Utukok River & 69.5539 & 160.3425 & Nanushuk Gp & 0.78 \\
\hline VO-3619 & Utukok River & 69.5539 & 160.6797 & Nanushuk Gp & 0.84 \\
\hline
\end{tabular}


Table 8a. Vitrinite reflectance values of coals across the surface in the Northern AlaskaSlope, Central Alaska-Nenana, and Southern Alaska-Cook Inlet coal provinces. - Continued

\begin{tabular}{|c|c|c|c|c|c|}
\hline $\begin{array}{l}\text { Record } \\
\text { number }\end{array}$ & $\begin{array}{c}\text { Quadrangle scale } \\
\text { of } 1: 250,000\end{array}$ & $\begin{array}{c}\text { North } \\
\text { latitude }\end{array}$ & $\begin{array}{c}\text { West } \\
\text { longitude }\end{array}$ & Formation & $\begin{array}{l}\text { Mean } \\
\mathbf{R}_{0}(\%)\end{array}$ \\
\hline VO-3620 & Utukok River & 69.5561 & 160.3619 & Nanushuk Gp & 0.73 \\
\hline VO-3621 & Utukok River & 69.5594 & 160.6800 & Nanushuk Gp & 0.85 \\
\hline VO-3622 & Utukok River & 69.5628 & 161.8406 & Nanushuk Gp & 0.73 \\
\hline VO-3623 & Utukok River & 69.5639 & 160.4261 & Nanushuk Gp & 0.71 \\
\hline VO-3624 & Utukok River & 69.5706 & 160.6736 & Nanushuk Gp & 0.67 \\
\hline VO-3625 & Utukok River & 69.5797 & 160.1897 & Nanushuk Gp & 0.89 \\
\hline VO-3626 & Utukok River & 69.5842 & 160.2878 & Nanushuk Gp & 0.70 \\
\hline VO-3627 & Utukok River & 69.5897 & 161.2425 & Nanushuk Gp & 0.79 \\
\hline VO-3628 & Utukok River & 69.5919 & 160.6736 & Nanushuk Gp & 0.70 \\
\hline VO-3629 & Utukok River & 69.5986 & 160.6706 & Nanushuk Gp & 0.69 \\
\hline VO-3630 & Utukok River & 69.6033 & 160.6675 & Nanushuk Gp & 0.73 \\
\hline VO-3631 & Utukok River & 69.6067 & 161.2456 & Nanushuk Gp & 0.79 \\
\hline VO-3632 & Utukok River & 69.6200 & 161.2456 & Nanushuk Gp & 0.83 \\
\hline VO-3633 & Utukok River & 69.6414 & 161.0161 & Nanushuk Gp & 0.69 \\
\hline VO-3634 & Utukok River & 69.6425 & 161.2419 & Nanushuk Gp & 0.86 \\
\hline VO-3635 & Utukok River & 69.6456 & 160.6614 & Nanushuk Gp & 0.77 \\
\hline VO-3636 & Utukok River & 69.6458 & 159.0708 & Nanushuk Gp & 0.58 \\
\hline VO-3637 & Utukok River & 69.6458 & 161.0356 & Nanushuk Gp & 0.66 \\
\hline VO-3638 & Utukok River & 69.6617 & 159.0614 & Nanushuk Gp & 0.65 \\
\hline VO-3639 & Utukok River & 69.6758 & 160.6486 & Nanushuk Gp & 0.67 \\
\hline VO-3640 & Utukok River & 69.6917 & 160.6389 & Nanushuk Gp & 0.70 \\
\hline VO-3641 & Utukok River & 69.6994 & 160.6358 & Nanushuk Gp & 0.69 \\
\hline VO-3642 & Utukok River & 69.6997 & 161.1928 & Nanushuk Gp & 0.63 \\
\hline VO-3643 & Utukok River & 69.7042 & 161.2153 & Nanushuk Gp & 0.64 \\
\hline VO-3644 & Utukok River & 69.7108 & 160.6294 & Nanushuk Gp & 0.67 \\
\hline VO-3645 & Utukok River & 69.7131 & 161.2669 & Nanushuk Gp & 0.60 \\
\hline VO-3646 & Utukok River & 69.7167 & 161.2800 & Nanushuk Gp & 0.60 \\
\hline VO-3647 & Utukok River & 69.7211 & 161.2992 & Nanushuk Gp & 0.63 \\
\hline VO-3648 & Utukok River & 69.7458 & 161.4092 & Nanushuk Gp & 0.60 \\
\hline VO-3649 & Utukok River & 69.7500 & 160.6264 & Nanushuk Gp & 0.61 \\
\hline VO-3650 & Utukok River & 69.7903 & 160.6169 & Nanushuk Gp & 0.78 \\
\hline VO-3651 & Wainwright & 70.0089 & 160.4542 & Nanushuk Gp & 0.52 \\
\hline VO-3652 & Wainwright & 70.0203 & 160.3358 & Nanushuk Gp & 0.60 \\
\hline VO-3653 & Wainwright & 70.0292 & 160.6839 & Nanushuk Gp & 0.57 \\
\hline VO-3654 & Wainwright & 70.0336 & 159.3061 & Nanushuk Gp & 0.58 \\
\hline VO-3655 & Wainwright & 70.0358 & 160.2536 & Nanushuk Gp & 0.55 \\
\hline VO-3656 & Wainwright & 70.0403 & 160.2239 & Nanushuk Gp & 0.54 \\
\hline VO-3657 & Wainwright & 70.0450 & 160.1942 & Nanushuk Gp & 0.60 \\
\hline VO-3658 & Wainwright & 70.0797 & 160.8689 & Nanushuk Gp & 0.51 \\
\hline VO-3659 & Wainwright & 70.0842 & 160.7339 & Nanushuk Gp & 0.57 \\
\hline VO-3660 & Wainwright & 70.1033 & 160.6253 & Nanushuk Gp & 0.52 \\
\hline VO-3661 & Wainwright & 70.1122 & 160.7539 & Nanushuk Gp & 0.54 \\
\hline VO-3662 & Wainwright & 70.1156 & 160.7606 & Nanushuk Gp & 0.63 \\
\hline VO-3663 & Wainwright & 70.1414 & 160.5661 & Nanushuk Gp & 0.52 \\
\hline
\end{tabular}


Table 8b. Vitrinite reflectance values of coals across the subsurface in the Northern Alaska-Slope, Central Alaska-Nenana, and Southern Alaska-Cook Inlet coal provinces. [Modified from Johnsson and others, 1992]

\begin{tabular}{|c|c|c|c|c|c|}
\hline $\begin{array}{l}\text { Record } \\
\text { number }\end{array}$ & $\begin{array}{c}\text { Quadrangle } \\
\text { scale of } \\
1: 250,000\end{array}$ & Well name & $\begin{array}{l}\text { North } \\
\text { latitude }\end{array}$ & $\begin{array}{c}\text { West } \\
\text { longitude }\end{array}$ & $\underset{R_{0}(\%)}{\text { Mean }}$ \\
\hline VW-0045 & (Offshore) & OCS-Y-0280-1 (Antares \#1) & 71.0361 & 152.7236 & 0.25 \\
\hline VW-0119 & Anchorage & American Quasar Big Lake \#1 & 61.5546 & 149.8004 & 0.43 \\
\hline VW-0142 & Anchorage & Beaver Lakes State \#1 & 61.6092 & 149.8597 & 0.49 \\
\hline VW-0173 & Anchorage & Fishhook \#1 & 61.6753 & 149.2613 & 0.51 \\
\hline VW-0175 & Anchorage & Lorraine State \#1 & 61.2989 & 149.9956 & 0.22 \\
\hline VW-0179 & Anchorage & Needham \#1 & 61.5835 & 149.3534 & 0.59 \\
\hline VW-0180 & Anchorage & Pittman \#1 & 61.6056 & 149.6390 & 0.47 \\
\hline VW-0185 & Anchorage & USA Big Lake \#1 & 61.4172 & 149.9142 & 0.47 \\
\hline VW-0208 & Anchorage & Wallace-Knuston \#1-A & 61.5442 & 149.4145 & 0.49 \\
\hline VW-0226 & Barrow & Avak \#1 & 71.2506 & 156.4681 & 0.50 \\
\hline VW-0232 & Barrow & North Simpson \#1 & 71.0569 & 154.9567 & 0.43 \\
\hline VW-0238 & Barrow & South Barrow \#1 & 71.3200 & 156.7042 & 0.45 \\
\hline VW-0250 & Barrow & South Barrow \#12 & 71.2372 & 156.3378 & 0.37 \\
\hline VW-0253 & Barrow & South Barrow \#13 & 71.2581 & 156.6192 & 0.42 \\
\hline VW-0260 & Barrow & South Barrow \#14 & 71.2317 & 156.2992 & 0.45 \\
\hline VW-0264 & Barrow & South Barrow \#15 & 71.2400 & 156.3436 & 0.52 \\
\hline VW-0268 & Barrow & South Barrow \#16 & 71.2822 & 156.5461 & 0.33 \\
\hline VW-0276 & Barrow & South Barrow \#17 & 71.2333 & 156.2594 & 0.50 \\
\hline VW-0286 & Barrow & South Barrow \#18 & 71.2503 & 156.2892 & 0.24 \\
\hline VW-0307 & Barrow & South Barrow \#19 & 71.2414 & 156.3336 & 0.48 \\
\hline VW-0321 & Barrow & South Barrow \#2 & 71.2619 & 156.6342 & 0.49 \\
\hline VW-0335 & Barrow & South Barrow \#3 & 71.1581 & 156.5669 & 0.45 \\
\hline VW-0351 & Barrow & South Barrow \#4 & 71.2642 & 156.6306 & 0.37 \\
\hline VW-0352 & Barrow & South Barrow \#9 & 71.2675 & 156.6147 & 0.56 \\
\hline VW-0355 & Barrow & Tulageak \#1 & 71.1889 & 155.7094 & 0.61 \\
\hline VW-0369 & Barrow & Walakpa \#1 & 71.0986 & 156.8856 & 0.43 \\
\hline VW-0391 & Barrow & Walakpa \#2 & 71.0503 & 156.9517 & 0.72 \\
\hline VW-0405 & Barrow & West Dease Test Well \#1 & 71.1592 & 155.6306 & 0.35 \\
\hline VW-0423 & Barter Island & Aurora \# 1 & 70.1092 & 142.7850 & 0.27 \\
\hline VW-0488 & Barter Island & Belcher \# 1 & 70.2752 & 141.5128 & 0.35 \\
\hline VW-0535 & Beechey Point & Beaufort Sea Blk. 54 \#1 & 70.4917 & 147.9842 & 0.30 \\
\hline VW-0572 & Beechey Point & BF-57 \#1 (Seal Island \#3) & 70.4914 & 148.6935 & 0.32 \\
\hline VW-0592 & Beechey Point & Delta State \#2 & 70.2606 & 148.0139 & 0.17 \\
\hline VW-0606 & Beechey Point & Gwydyr Bay South \#1 & 70.4017 & 148.8981 & 0.46 \\
\hline VW-0608 & Beechey Point & Gwydyr Bay State \#1 & 70.4200 & 149.0178 & 0.44 \\
\hline VW-0624 & Beechey Point & Jeanette Island \#1 & 70.3617 & 147.4072 & 0.28 \\
\hline VW-0659 & Beechey Point & Kavearak Point \#32-25 & 70.4553 & 149.4356 & 0.30 \\
\hline VW-0697 & Beechey Point & Kuparuk River Unit \#3A-9 & 70.4028 & 149.9378 & 0.25 \\
\hline VW-0711 & Beechey Point & Long Island \#1 & 70.4867 & 149.0161 & 0.42 \\
\hline
\end{tabular}


Table 8b. Vitrinite reflectance values of coals across the subsurface in the Northern Alaska-Slope, Central Alaska-Nenana, and Southern Alaska-Cook Inlet coal provinces. - Continued

\begin{tabular}{|c|c|c|c|c|c|}
\hline $\begin{array}{l}\text { Record } \\
\text { number }\end{array}$ & $\begin{array}{c}\text { Quadrangle } \\
\text { scale of } \\
1: 250,000\end{array}$ & Well name & $\begin{array}{l}\text { North } \\
\text { latitude }\end{array}$ & $\begin{array}{c}\text { West } \\
\text { longitude }\end{array}$ & $\begin{array}{c}\text { Mean } \\
\mathbf{R}_{0}(\%)\end{array}$ \\
\hline VW-0734 & Beechey Point & No Name Island \#1 & 70.4608 & 147.9350 & 0.46 \\
\hline VW-0778 & Beechey Point & Northwest Eileen \#1 & 70.3653 & 149.3586 & 0.46 \\
\hline VW-0779 & Beechey Point & OCS-Y-370-1 (Sandpiper \#1) & 70.5848 & 149.0969 & 0.22 \\
\hline VW-0794 & Beechey Point & Placid Et Al State \#1 & 70.2494 & 148.8186 & 0.24 \\
\hline VW-0802 & Beechey Point & Point McIntyre \#1 & 70.3968 & 148.6062 & 0.32 \\
\hline VW-0810 & Beechey Point & Prudhoe Bay \#36-11 & 70.2686 & 148.4753 & 0.39 \\
\hline VW-0818 & Beechey Point & Prudhoe Bay Unit \#R-1 & 70.3453 & 148.8792 & 0.33 \\
\hline VW-0844 & Beechey Point & Put River \#24-10-14 & 70.2019 & 148.4664 & 0.38 \\
\hline VW-0851 & Beechey Point & Put River (J-1) \#9-11-13 & 70.3272 & 148.8389 & 0.46 \\
\hline VW-0855 & Beechey Point & Sag Delta \#31-10-16 & 70.1828 & 148.1550 & 0.48 \\
\hline VW-0866 & Beechey Point & Sag Delta \#33-12-16 & 70.3408 & 148.1044 & 0.44 \\
\hline VW-0867 & Beechey Point & Sag Delta \#8 & 70.3697 & 148.0514 & 0.50 \\
\hline VW-0890 & Beechey Point & Sag River \#1 & 70.2544 & 148.3425 & 0.26 \\
\hline VW-0900 & Beechey Point & Simpson Lagoon \#32-14A & 70.4828 & 149.7328 & 0.10 \\
\hline VW-0918 & Beechey Point & Toolik Federal \#1 & 70.0731 & 148.3928 & 0.52 \\
\hline VW-0926 & Beechey Point & Toolik Federal \#2 & 70.0717 & 149.2067 & 0.32 \\
\hline VW-0938 & Beechey Point & Toolik Federal \#3 & 70.0764 & 149.9006 & 0.26 \\
\hline VW-0943 & Beechey Point & W Mikkelson Unit \#3 & 70.1981 & 147.3153 & 0.37 \\
\hline VW-0955 & Beechey Point & W. Mikkelson Unit \#2 & 70.2206 & 147.1880 & 0.52 \\
\hline VW-0965 & Beechey Point & West Beach State \#2 & 70.3581 & 148.4744 & 0.48 \\
\hline VW-0967 & Beechey Point & West Kuparuk \#3-11-11 & 70.3350 & 149.3067 & 0.44 \\
\hline VW-0987 & Beechey Point & West Mikkelsen Unit \#4 & 70.2174 & 147.3442 & 0.17 \\
\hline VW-1034 & Chandler Lake & Grandstand \#1 & 68.9658 & 151.9169 & 0.48 \\
\hline VW-1039 & Chandler Lake & Tulugak \#1 & 68.9758 & 151.1169 & 0.38 \\
\hline VW-1111 & De Long Mountains & Eagle Creek \#1 & 68.7086 & 162.5522 & 1.46 \\
\hline VW-1127 & Fairbanks & Nenana \#1 & 64.5797 & 149.6375 & 0.31 \\
\hline VW-1149 & Flaxman Island & Alaska Island \#1 & 70.2275 & 146.5000 & 0.34 \\
\hline VW-1191 & Flaxman Island & Alaska State \#D-1 & 70.2031 & 146.2072 & 0.35 \\
\hline VW-1214 & Flaxman Island & Alaska State \#F-1 & 70.2267 & 146.3603 & 0.36 \\
\hline VW-1254 & Flaxman Island & Challenge Island \#1 & 70.2356 & 146.6178 & 0.15 \\
\hline VW-1273 & Flaxman Island & E. De K. Leffingwell \#1 & 70.0178 & 146.5168 & 0.30 \\
\hline VW-1295 & Flaxman Island & East Mikkelsen Bay \#1 & 70.1519 & 146.9028 & 0.29 \\
\hline VW-1316 & Flaxman Island & OCS-Y-849-1 (Hammerhead) & 70.3646 & 146.0244 & 0.37 \\
\hline VW-1401 & Flaxman Island & OCS-Y-849-2 (Hammerhead \#2) & 70.3783 & 146.0312 & 0.51 \\
\hline VW-1445 & Flaxman Island & OCS-Y-871-1 (Corona \#1) & 70.3146 & 144.7591 & 0.23 \\
\hline VW-1504 & Flaxman Island & Point Thompson \#3 & 70.1714 & 146.2522 & 0.48 \\
\hline VW-1526 & Flaxman Island & Point Thomson \#2 & 70.1631 & 146.5142 & 0.31 \\
\hline VW-1548 & Flaxman Island & Point Thomson \#1 & 70.1739 & 146.3533 & 0.46 \\
\hline VW-1592 & Flaxman Island & West Staines State \#2 & 70.1103 & 146.4161 & 0.37 \\
\hline VW-1677 & Harrison Bay & Atigaru Point \#1 & 70.5561 & 151.7169 & 0.32 \\
\hline VW-1696 & Harrison Bay & Cape Halkett \#1 & 70.7672 & 152.4664 & 0.22 \\
\hline VW-1710 & Harrison Bay & East Harrison Bay \#1 & 70.4928 & 150.0317 & 0.48 \\
\hline
\end{tabular}


Table 8b. Vitrinite reflectance values of coals across the subsurface in the Northern Alaska-Slope, Central Alaska-Nenana, and Southern Alaska-Cook Inlet coal provinces. - Continued

\begin{tabular}{|c|c|c|c|c|c|}
\hline $\begin{array}{l}\text { Record } \\
\text { number }\end{array}$ & $\begin{array}{c}\text { Quadrangle } \\
\text { scale of } \\
1: 250,000\end{array}$ & Well name & $\begin{array}{l}\text { North } \\
\text { latitude }\end{array}$ & $\begin{array}{c}\text { West } \\
\text { longitude }\end{array}$ & $\begin{array}{c}\text { Mean } \\
\mathbf{R}_{0}(\%)\end{array}$ \\
\hline VW-1723 & Harrison Bay & Fish Creek \#1 & 70.3206 & 151.9689 & 0.31 \\
\hline VW-1733 & Harrison Bay & Itkillik River Unit \#1 & 70.0658 & 150.8531 & 0.73 \\
\hline W-1779 & Harrison Bay & Nechelik \#1 & 70.3928 & 150.9789 & 0.28 \\
\hline VW-1811 & Harrison Bay & North Inigok \#1 & 70.2569 & 152.6639 & 0.28 \\
\hline VW-1830 & Harrison Bay & North Kalikpik \#1 & 70.5092 & 152.3678 & 0.28 \\
\hline VW-1860 & Harrison Bay & OCS-Y-0302-1 (Mars) & 70.8430 & 152.0718 & 0.25 \\
\hline VW-1869 & Harrison Bay & OCS-Y-334-1 (Mukluk \#1) & 70.6833 & 150.9200 & 0.30 \\
\hline VW-1923 & Harrison Bay & OCS-Y-338-1 (Phoenix \#1) & 70.7169 & 150.4278 & 0.24 \\
\hline VW-1948 & Harrison Bay & OCS-Y-804-1 (Orion) & 70.9562 & 152.0630 & 0.26 \\
\hline VW-1957 & Harrison Bay & South Harrison Bay \# 1 & 70.4247 & 151.7311 & 0.24 \\
\hline VW-1990 & Harrison Bay & W T Foran $\# 1$ & 70.8322 & 152.3031 & 0.23 \\
\hline VW-2006 & Harrison Bay & West Fish Creek \#1 & 70.3264 & 152.0606 & 0.33 \\
\hline VW-2021 & Ikpikpuk River & East Oumalik\#1 & 69.7914 & 155.5442 & 0.46 \\
\hline VW-2030 & Ikpikpuk River & Knifeblade \#1 & 69.1508 & 154.8892 & 0.55 \\
\hline VW-2035 & Ikpikpuk River & Knifeblade \#2A & 69.1386 & 154.7367 & 0.63 \\
\hline VW-2038 & Ikpikpuk River & Koluktak Test Well \#1 & 69.7778 & 154.5308 & 0.35 \\
\hline VW-2048 & Ikpikpuk River & Oumalik \#1 & 69.8381 & 155.9900 & 0.36 \\
\hline VW-2074 & Ikpikpuk River & Square Lake \#1 & 69.5667 & 153.3000 & 0.49 \\
\hline VW-2090 & Ikpikpuk River & Titaluk \#1 & 69.4225 & 154.5678 & 0.55 \\
\hline VW-2097 & Ikpikpuk River & Wolf Creek \#1 & 69.3864 & 153.5206 & 0.58 \\
\hline VW-2100 & Ikpikpuk River & Wolf Creek \#3 & 69.3864 & 153.5233 & 0.51 \\
\hline VW-2109 & Iliamna & Iniskin Beal \#1 & 59.7411 & 153.2261 & 0.60 \\
\hline VW-2173 & Iliamna & Iniskin Zappa \#1 & 59.7458 & 153.2458 & 0.48 \\
\hline VW-2257 & Kenai & ARCO/CIRI Funny River \#1 & 60.4222 & 150.9633 & 0.39 \\
\hline VW-2280 & Kenai & Beaver Creek Unit \#4 & 60.6561 & 151.0297 & 0.26 \\
\hline VW-2295 & Kenai & Clam Gulch 1-X & 60.2044 & 151.5256 & 0.37 \\
\hline VW-2322 & Kenai & Deep Creek \#1 & 60.0081 & 151.4847 & 0.39 \\
\hline VW-2325 & Kenai & Edna Mae Walker \#1 & 60.0456 & 151.2881 & 0.29 \\
\hline VW-2372 & Kenai & Kustatan River \#1 & 60.8087 & 151.9145 & 0.25 \\
\hline VW-2380 & Kenai & Soldotna Creek Unit \#22-32 & 60.6548 & 150.8984 & 0.33 \\
\hline VW-2400 & Kenai & Soldotna Creek Unit \#33-33 & 60.7372 & 150.8619 & 0.56 \\
\hline VW-2425 & Kenai & SRS MGS State \#1 & 60.8123 & 151.4828 & 0.48 \\
\hline VW-2436 & Kenai & Swanson River Unit \#34-10 & 60.7931 & 150.8333 & 0.35 \\
\hline VW-2437 & Killik River & East Kurupa Unit \# 1 & 68.8402 & 153.3036 & 0.63 \\
\hline VW-2464 & Killik River & Lisburne \#1 & 68.4783 & 155.6506 & 0.43 \\
\hline VW-2584 & Lookout Ridge & Awuna Test Well \#1 & 69.1478 & 158.0242 & 0.55 \\
\hline VW-2599 & Meade River & Brontosaurus \#1 & 70.8995 & 157.2494 & 0.61 \\
\hline VW-2603 & Meade River & Kugrua \#1 & 70.5869 & 158.6619 & 0.49 \\
\hline VW-2650 & Meade River & Kuyanak \#1 & 70.9325 & 156.0322 & 0.58 \\
\hline VW-2666 & Meade River & Meade \#1 & 70.0417 & 157.4894 & 0.50 \\
\hline VW-2766 & Mount Michelson & Beli Unit \#1 & 69.7106 & 146.5353 & 0.46 \\
\hline VW-2782 & Mount Michelson & Canning River Unit \#A-1 & 69.6061 & 146.3353 & 0.72 \\
\hline
\end{tabular}


Table 8b. Vitrinite reflectance values of coals across the subsurface in the Northern Alaska-Slope, Central Alaska-Nenana, and Southern Alaska-Cook Inlet coal provinces. - Continued

\begin{tabular}{|c|c|c|c|c|c|}
\hline $\begin{array}{l}\text { Record } \\
\text { number }\end{array}$ & $\begin{array}{c}\text { Ouadrangle } \\
\text { scale of } \\
1: 250,000\end{array}$ & Well name & $\begin{array}{l}\text { North } \\
\text { latitude }\end{array}$ & $\begin{array}{c}\text { West } \\
\text { longitude }\end{array}$ & $\begin{array}{c}\text { Mean } \\
\mathrm{R}_{0}(\%)\end{array}$ \\
\hline VW-2804 & Mount Michelson & Canning River Unit \#B-1 & 69.6636 & 146.2753 & 0.57 \\
\hline VW-2837 & Mount Michelson & Kavik \#1 & 69.6317 & 146.5694 & 0.84 \\
\hline VW-2898 & Point Lay & Akulik \#1 & 68.9919 & 163.4872 & 0.45 \\
\hline VW-2931 & Point Lay & Tungak Creek \#1 & 69.8828 & 162.2722 & 0.54 \\
\hline VW-2954 & Sagavanirktok & Aufeis Unit \#1 & 69.1497 & 149.5717 & 0.50 \\
\hline VW-2976 & Sagavanirktok & Bush Federal \#1 & 69.6583 & 149.0331 & 0.38 \\
\hline VW-3047 & Sagavanirktok & Echooka Unit \#1 & 69.4000 & 148.2686 & 0.38 \\
\hline VW-3088 & Sagavanirktok & Fin Creek Unit \#1 & 69.5000 & 147.6000 & 0.45 \\
\hline VW-3121 & Sagavanirktok & Kemik \#1 & 69.4397 & 147.2658 & 0.64 \\
\hline VW-3167 & Sagavanirktok & Kemik Unit \#2 & 69.3864 & 147.1556 & 1.18 \\
\hline VW-3200 & Sagavanirktok & Lupine Unit \#1 & 69.1011 & 148.6183 & 0.83 \\
\hline VW-3213 & Sagavanirktok & Nora Federal \#1 & 69.5517 & 148.7519 & 0.16 \\
\hline VW-3230 & Sagavanirktok & Shaviovik Unit \#1 & 69.5419 & 147.5206 & 0.52 \\
\hline VW-3254 & Sagavanirktok & West Kavik \#1 & 69.7700 & 147.1856 & 0.85 \\
\hline VW-3275 & Seldovia & Anchor Point \#1 & 59.7533 & 151.8226 & 0.21 \\
\hline VW-3285 & Seldovia & Coal Bay State \# 1 & 59.6611 & 151.3522 & 0.29 \\
\hline VW-3292 & Seldovia & Lwr Cook Inlet COST \#1 & 59.5183 & 152.6433 & 0.29 \\
\hline VW-3328 & Seldovia & North Fork Unit 41-35 & 59.7925 & 151.6257 & 0.38 \\
\hline VW-3341 & Seldovia & OCS-Y-086-1 & 59.7083 & 152.1578 & 0.40 \\
\hline VW-3388 & Seldovia & OCS-Y-097-1 (Raven \#1) & 59.6039 & 152.5822 & 0.48 \\
\hline VW-3414 & Seldovia & OCS-Y-113-1 (Ibis \#1) & 59.4139 & 152.6842 & 0.40 \\
\hline VW-3419 & Seldovia & OCS-Y-243-1 (Falcon Prospect) & 59.7794 & 152.6000 & 0.47 \\
\hline VW-3436 & Seldovia & South Caribou Hills Unit \# 1 & 59.8217 & 151.2522 & 0.22 \\
\hline VW-3442 & Seldovia & South Diamond Gulch Unit \#1 & 59.6914 & 151.7164 & 0.27 \\
\hline VW-3464 & Teshekpuk & Drew Point \#1 & 70.8797 & 153.8997 & 0.30 \\
\hline VW-3496 & Teshekpuk & East Simpson \#1 & 70.9178 & 154.6178 & 0.33 \\
\hline VW-3529 & Teshekpuk & East Simpson \#2 & 70.9783 & 154.6736 & 0.29 \\
\hline VW-3548 & Teshekpuk & East Topagoruk \#1 & 70.5769 & 155.3725 & 0.47 \\
\hline VW-3556 & Teshekpuk & Ikpikpuk \#1 & 70.4556 & 154.3325 & 0.37 \\
\hline VW-3612 & Teshekpuk & Inigok \#1 & 70.0000 & 153.0944 & 0.40 \\
\hline VW-3702 & Teshekpuk & J. W. Dalton \#1 & 70.9200 & 153.1378 & 0.45 \\
\hline VW-3738 & Teshekpuk & Simpson \#1 & 70.9531 & 155.3642 & 0.59 \\
\hline VW-3748 & Teshekpuk & South Simpson \#1 & 70.8067 & 154.9817 & 0.62 \\
\hline VW-3757 & Teshekpuk & Topagoruk \#1 & 70.6250 & 155.8931 & 0.34 \\
\hline VW-3779 & Tyonek & Albert Kaloa \#1 & 61.0197 & 151.3484 & 0.34 \\
\hline VW-3824 & Tyonek & Bell Island \# 1 & 61.4009 & 152.4610 & 0.44 \\
\hline VW-3827 & Tyonek & Chuitna Riv St 3193 \#1 & 61.1354 & 151.3728 & 0.48 \\
\hline VW-3852 & Tyonek & Cook Inlet St. $17589 \# 1$ & 61.0667 & 150.9533 & 0.24 \\
\hline VW-3893 & Tyonek & Cook Inlet Unit \#A-12 & 61.0767 & 150.9481 & 0.60 \\
\hline VW-3905 & Tyonek & Fish Creek \#1 & 61.5620 & 150.2716 & 0.32 \\
\hline VW-3906 & Tyonek & Ivan River 44-1 & 61.2404 & 150.7967 & 0.12 \\
\hline VW-3909 & Tyonek & Lewis River 13-2 & 61.3310 & 150.8485 & 0.37 \\
\hline
\end{tabular}


Table $\mathbf{8 b}$. Vitrinite reflectance values of coals across the subsurface in the Northern Alaska-Slope, Central Alaska-Nenana, and Southern Alaska-Cook Inlet coal provinces. - Continued

\begin{tabular}{l|l|l|c|c|c}
\hline $\begin{array}{c}\text { Record } \\
\text { number }\end{array}$ & $\begin{array}{c}\text { Quadrangle } \\
\text { Scale of } \\
\mathbf{1 : 2 5 0 , 0 0 0}\end{array}$ & Well name & $\begin{array}{c}\text { North } \\
\text { latitude }\end{array}$ & $\begin{array}{c}\text { West } \\
\text { longitude }\end{array}$ & $\begin{array}{c}\text { Mean } \\
\mathbf{R}_{\mathbf{0}}(\mathbf{\%})\end{array}$ \\
\hline VW-3944 & Tyonek & Long Lake \#1 & 61.0831 & 151.4307 & 0.31 \\
VW-3947 & Tyonek & Moquawkie \#1 & 61.0739 & 151.3189 & 0.29 \\
VW-3985 & Tyonek & Nicolai Creek Unit \#4 & 61.0140 & 151.4299 & 0.26 \\
VW-4026 & Tyonek & Pretty Creek St. \#1 & 61.3264 & 151.0057 & 0.27 \\
VW-4027 & Tyonek & Red Shirt Lake \#1 & 61.6410 & 150.0941 & 0.31 \\
VW-4127 & Umiat & Gubik \#1 & 69.4228 & 151.4472 & 0.35 \\
VW-4139 & Umiat & Gubik \#2 & 69.4325 & 151.4644 & 0.41 \\
VW-4151 & Umiat & Itkillik Unit \#1 & 69.4547 & 150.5747 & 0.51 \\
VW-4171 & Umiat & Seabee \#1 & 69.3794 & 152.1731 & 0.52 \\
VW-4211 & Umiat & Umiat \#1 & 69.3964 & 152.3281 & 0.48 \\
VW-4219 & Umiat & Umiat \#11 & 69.4047 & 152.0953 & 0.50 \\
VW-4233 & Umiat & Umiat \#2 & 69.3819 & 152.0825 & 0.64 \\
VW-4258 & Utukok River & Kaolak \#1 & 69.9331 & 160.2475 & 0.56 \\
VW-4285 & Wainwright & Peard \#1 & 70.7156 & 159.0006 & 0.46 \\
VW-4318 & Wainwright & Tunalik \#1 & 70.1967 & 161.0719 & 0.56 \\
\hline
\end{tabular}

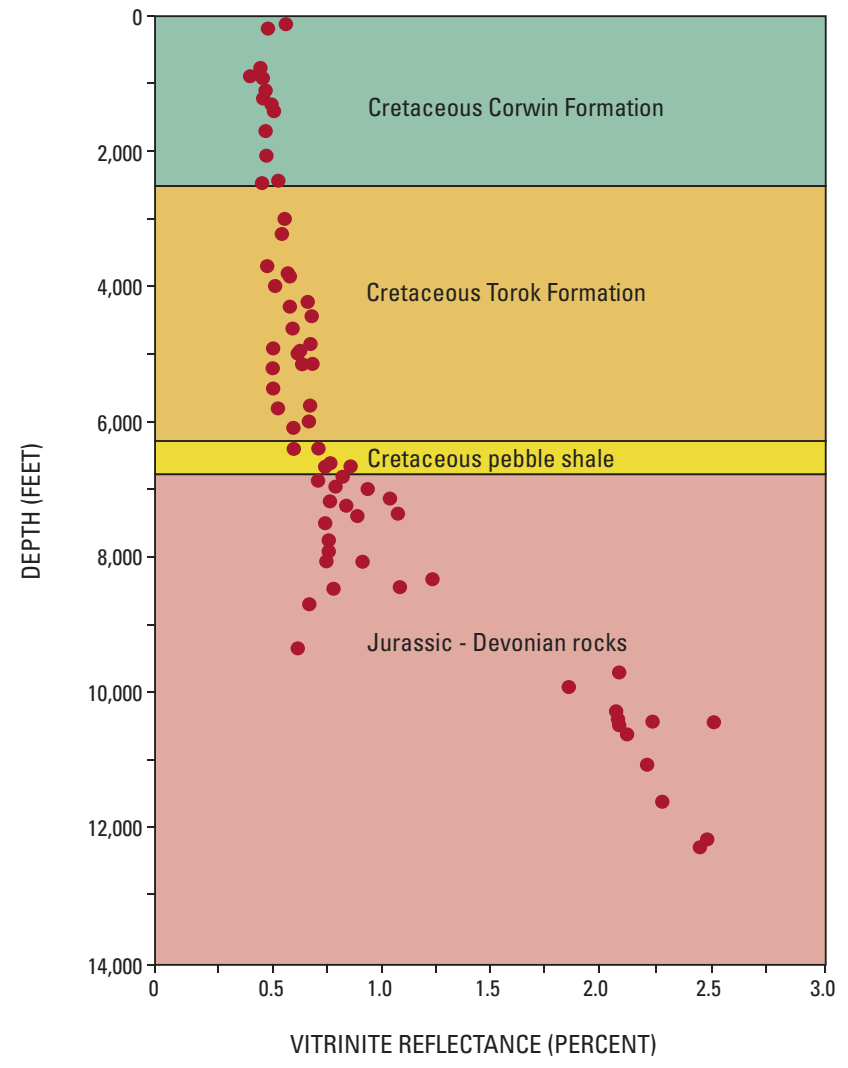

Figure 105. Vitrinite reflectance values for the Meade Quadrangle, National Petroleum Reserve in Alaska. Modified from Magoon and Bird (1988).

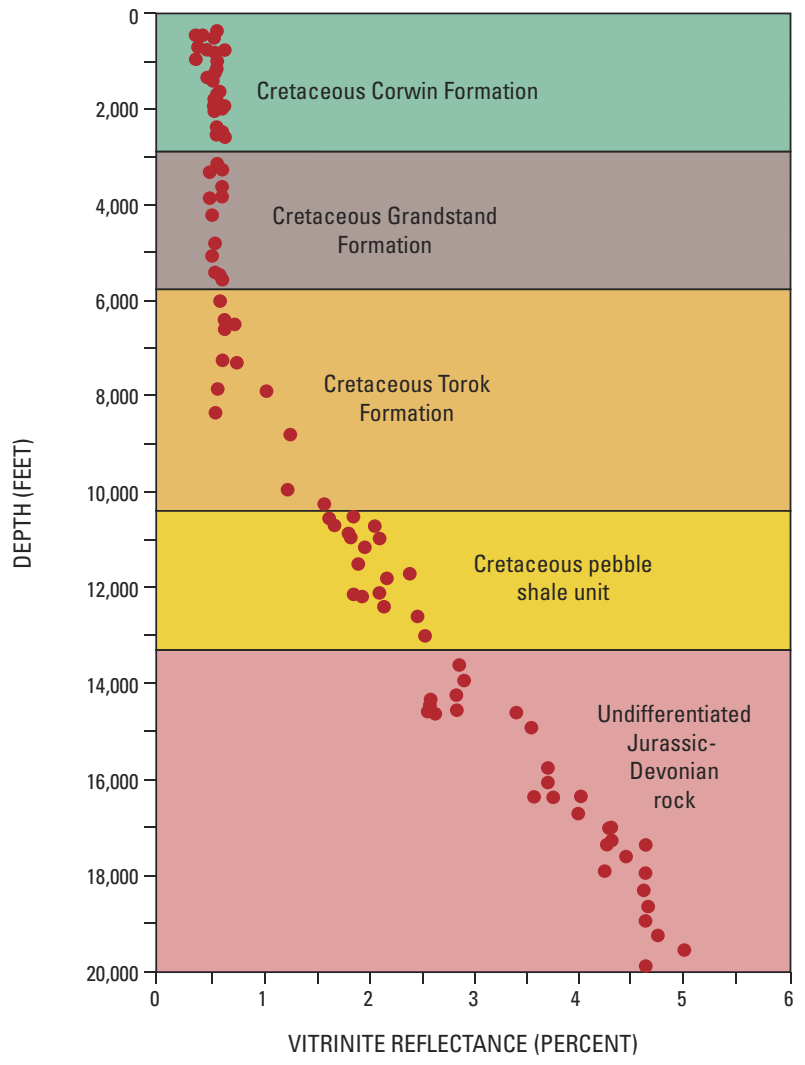

Figure 106. Vitrinite reflectance values for the Tunalik No. 1 well, National Petroleum Reserve in Alaska. Modified from Magoon and Bird (1988). 
Cook Inlet are in the Tyonek area where the coal beds in the Tyonek are as much as $50 \mathrm{ft}(15 \mathrm{~m})$ thick occurring at shallow depths of less than $2,000 \mathrm{ft}(610 \mathrm{~m})$. Also, the infrastructure (for example, pipeline) of existing petroleum development is readily available in the area.

A basinwide variation in thermal maturity of the Cook Inlet Basin was determined by Johnsson and others (1993) from vitrinite reflectance values of 30 offshore and onshore wells (fig. 114). Reflectance values range from 0.24 to 0.95 percent with high values ( $0.6-0.8$ percent) occurring at increasing depths in the northeastern and southwestern parts of the Cook Inlet Basin (see fig. 114). This indicates that tectonic deformation and volcanism along the Aleutian volcanic arc influenced the high reflectance values in the northeastern part of the basin, particularly in the Matanuska Valley. The localized upgrading of the thermal maturity in the Matanuska Valley, based on reflectance values of the Tyonek coal beds, is shown in figure 115 (Smith, 1995). Here, the Tyonek coal beds are mainly subbituminous, but the older coal beds in the eastern part of the valley range from bituminous to semianthracite. The central part of the basin maintains reflectance values from 0.4 to 0.6 percent, which indicate burial influence by thick sedimentary rock sequences of 12,000-13,000 ft (3,660$3,960 \mathrm{~m}$ ) (see figs. 58, 59, and 60) along the basin center. Thermal maturity measured from vitrinite reflectance data is relatively low. Shi-Ming (1996) suggested, in a study of clay mineral diagenesis, that temperatures never exceeded $167^{\circ} \mathrm{F}$ $\left(75^{\circ} \mathrm{C}\right.$ ) (fig. 116). Rapid rate of subsidence and sedimentation of the Cook Inlet Basin probably controlled the low thermal maturity of the Tyonek, Beluga, and Sterling coal beds. Generalized vitrinite reflectance lines are superimposed on the cross sections in figures 117 and 118 .

Coal beds identified in lithologic logs of the Tyonek and Beluga Formations in the Edna Mae Walker No. 1 well in Kenai Peninsula (see fig. 116) are directly associated with the high gas shows indicated on the mud logs (fig. 116). These coal beds contain as much as 2.5 percent by volume of coalbed methane marked by high gas kicks (see fig. 116). However, based on the downhole hot wire total gas results (see high gas kicks in fig. 116), the coal beds in the upper part of the Tyonek Formation contain by far the most coalbed methane resources. Coal beds in the lower part of the Beluga Formation consist of moderate amounts of coalbed methane resources. Coal beds of the Sterling Formation contain very low coalbed methane concentrations. The difference in the coalbed methane content between the Beluga and Sterling coals may be related to the variation in their rank, beds in the Sterling Formation being mainly lignite and those in the Tyonek and Beluga beds being mainly subbituminous (Barnes and Cobb, 1959). Vitrinite reflectance values of the Sterling Formation coal beds range from 0.32 to 0.44 percent, the Beluga coal beds from 0.42 to 0.58 percent, and the Tyonek Formation coal beds from 0.45 to 0.66 percent; all values increase with depth (fig. 117). These vitrinite reflectance values are closely similar to the subbituminous Paleocene Fort Union coal beds (0.31-0.49 percent) in the Powder River Basin of Wyoming and Montana, which have an average gas content of $25 \mathrm{scf} / \mathrm{t}$. Also, the gas content (based on the hot wire total gas and methane in mud logs; see fig. 116) of the Powder River Basin coal beds appears to increase with depth, from below $6,000 \mathrm{ft}(1,830 \mathrm{~m})$ to more than $13,000 \mathrm{ft}(3,960 \mathrm{~m})$. However, producibility of gas from coal-bed reservoirs at these depths may be negligible due to low permeability below 6,000 ft (1,830 m) (McKee and others, 1986). Thus, by comparison, coal beds of the upper Tyonek and lower Beluga Formations contain the best coalbed methane potential in the Kenai Peninsula, especially reservoirs less than $6,000 \mathrm{ft}(1,830 \mathrm{~m})$ deep. The upper part of the Beluga Formation is mainly exposed along the beach bluffs in the southern Kenai Peninsula. Thus, the targeted coal beds of the lower Beluga and upper Tyonek occur in subcrop and at shallower depths than in the Edna Mae Walker well along the south coast of the Kenai Peninsula.

The hypothetical coal resources of the coal-bearing Kenai Group in the Cook Inlet Basin were estimated to be as much as 1.55 trillion short tons (1.45 trillion metric tons) (see table 1). As much as 1.5 trillion short tons (1.36 trillion short tons) of these coal resources is offshore (see table 1). Based on the gas contents of the Tyonek coal beds in the upper Cook Inlet by Smith (1995), which range from 63-245 scf/t (1.97$7.6 \mathrm{scm}^{3} / \mathrm{gm}$ ) at STP, the in-place methane resources in that part of the basin may be high. However, based on the subbituminous and lignite ranks and the similarity of the vitrinite reflectance values of the Tyonek, Beluga, and Sterling coal beds in the central and southern parts of the basin to those of the Fort Union coal beds in the Powder River Basin, these coals may provide a lower-end estimate of the gas content in the Cook Inlet Basin.

\section{Summary}

Nearly all the coal resources calculated for Alaska are in Cretaceous and Tertiary rocks distributed in three major coal provinces. The Cretaceous coal resources, generally of bituminous and lignite rank, are mainly in the Northern Alaska-Slope coal province with 3,200 billion short tons (2,902 billion metric tons) of hypothetical resources. A minor amount of Tertiary coal resources are in the Northern AlaskaSlope coal province with 670 billion short tons (608 billion short tons) of hypothetical resources. Most of the Tertiary coal resources, mainly lignite to subbituminous with minor bituminous and semianthracite, are in the Central AlaskaNenana and Southern Alaska-Cook Inlet coal provinces with more than 1,600 billion short tons (1,451 billion metric tons) of combined measured, indicated, inferred, and hypothetical resources. These three coal provinces contain about 87 percent of the total coal resources and represent most of the minable coal beds of Alaska. Combined coal resources (measured, indicated, inferred, and hypothetical resources) in the Northern Alaska-Slope, Central Alaska-Nenana, and Southern Alaska-Cook Inlet coal provinces are about 5,526 billion short 


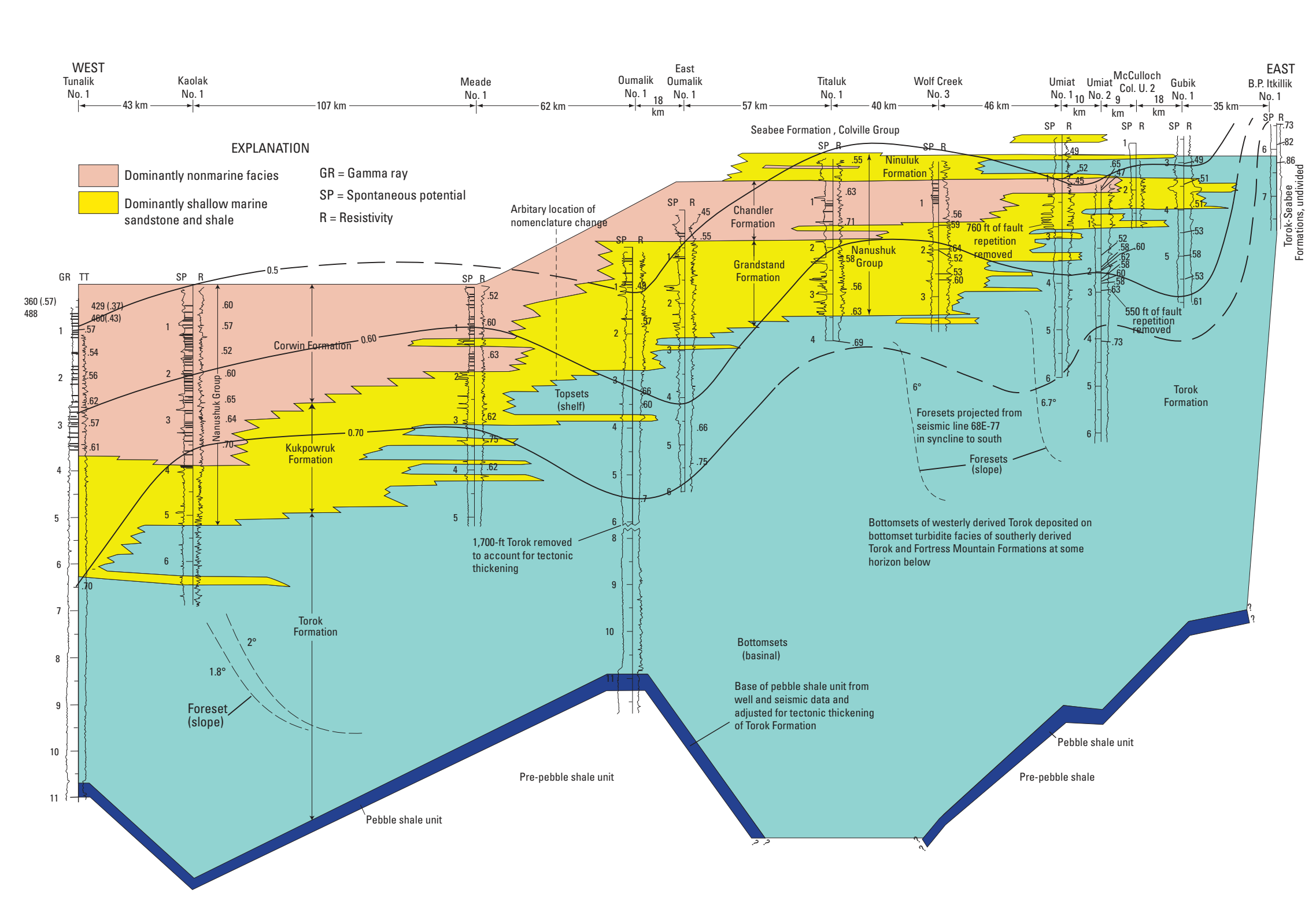

Figure 107. Stratigraphic cross section of the Nanushuk Group with superimposed vitrinite reflectance values. See figure 8 for location of cross section. 


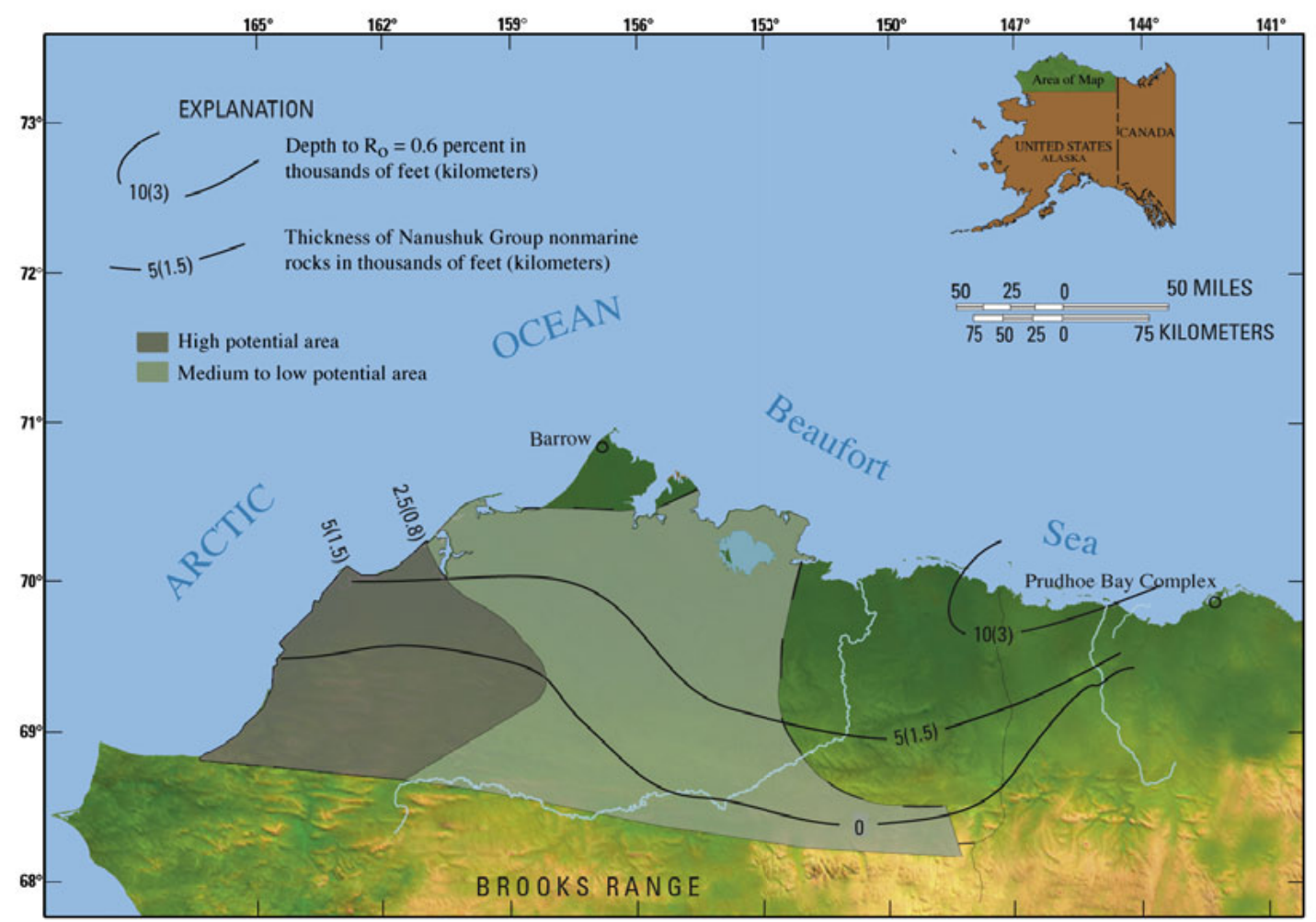

Figure 108. Coalbed methane potential in the Nanushuk Group coals based on the thickness and vitrinite reflectance of the nonmarine part of the group in the Northern Alaska-Slope coal province. Adopted from Smith (1995).

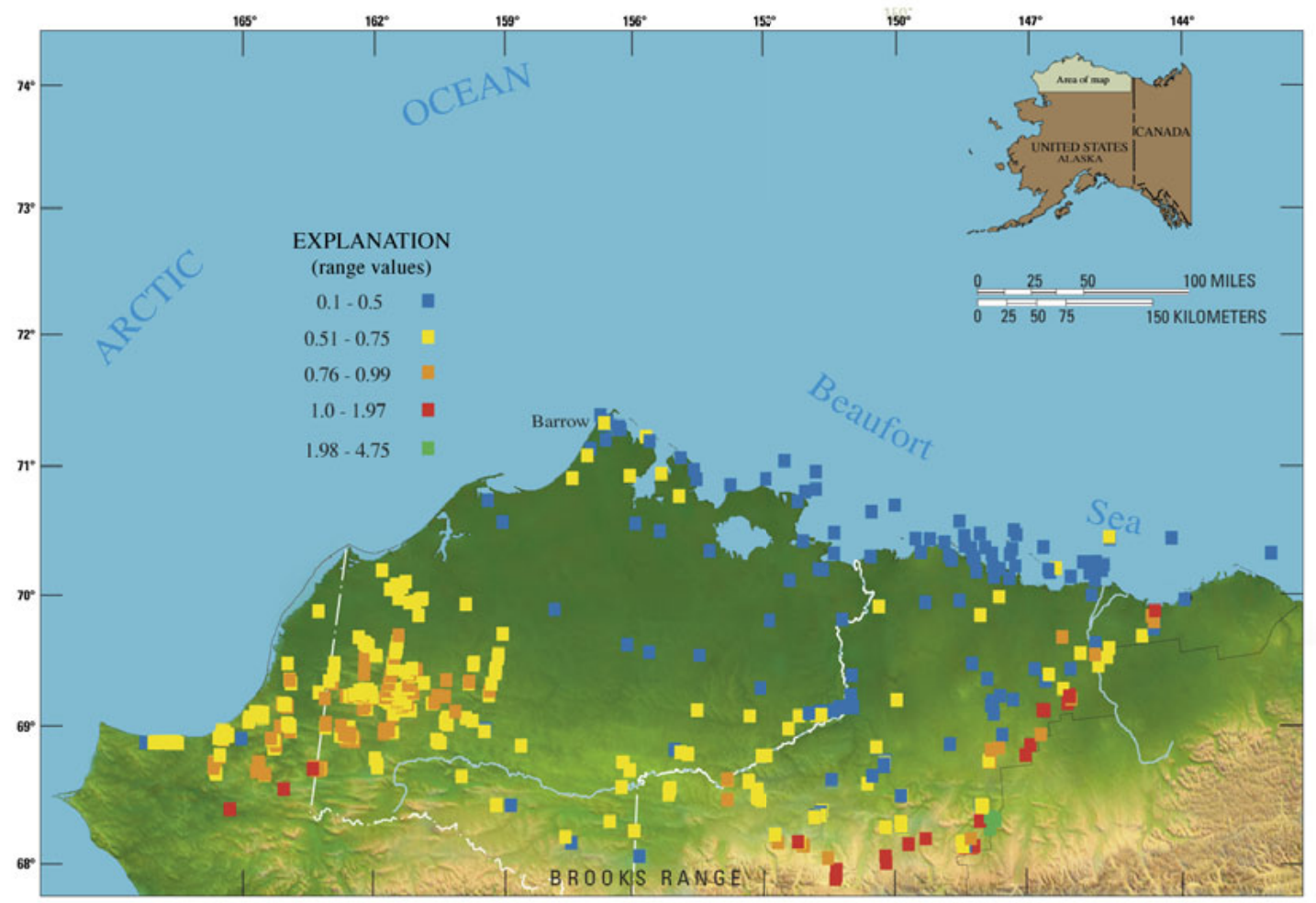

Figure 109. Distribution of surface vitrinite reflectance $\left(R_{0}\right)$ values in the Northern Alaska-Slope coal province. 
Table 9. Properties of sandstone reservoirs and associated gas in the Sterling and Beluga Formations. Modified from Brimberry and others (1997).

\begin{tabular}{ll}
\hline & \multicolumn{1}{c}{ Reservoir data of Kenai field } \\
\hline Total completions: & 69 (commingled flow, typically dual tubing strings) \\
Spacing: & $160-320$ acres \\
Drive: & Gas expansion \\
Structure: & Simple anticlines \\
Gas analysis: & $99 \%$ methane; $0.5 \%$ nitrogen; $0.2 \%$ carbon dioxide; 1,008 Btu per cubic foot; \\
& 0.56 specific gravity \\
\hline
\end{tabular}

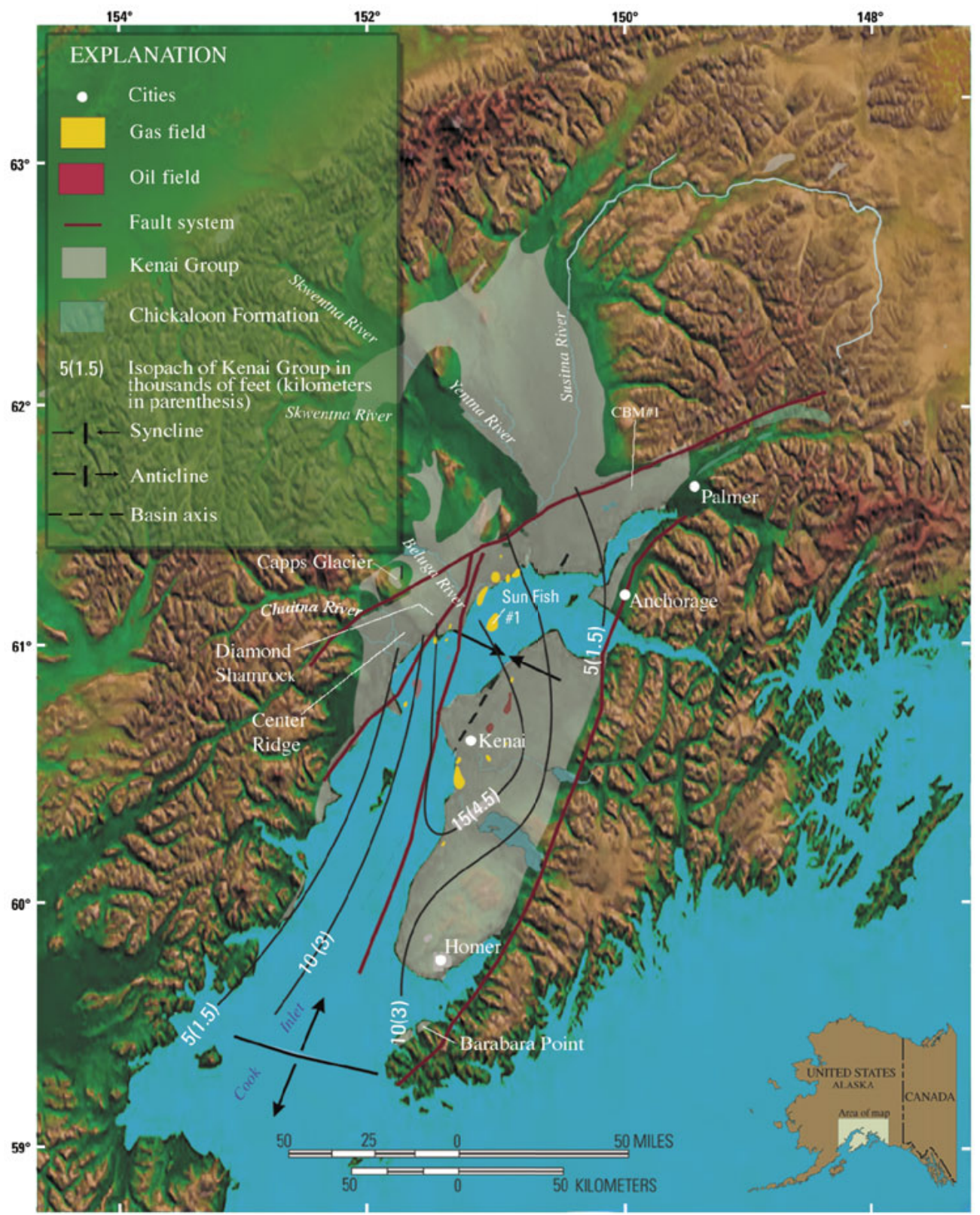

Figure 110. Map of the Cook Inlet Basin showing distribution of oil and gas fields offshore and onshore. CBM \#1 is the well studied by Smith (1995). 
tons $(5,012$ billion metric tons). Of this total, 13.5 billion short tons (13.2 billion metric tons) are identified coal resources mainly from the Central Alaska-Nenana and Southern AlaskaCook Inlet coal provinces. Thus, only a small fraction of the total coal resources of Alaska is known, and a large amount is undiscovered.

Coal mining has been intermittently attempted in the Central Alaskan-Nenana and Southern Alaska-Cook Inlet coal provinces. A dozen or more underground and strip mines in these two coal provinces have produced over 40 million short tons (36 million metric tons). Thus, only a small fraction of the identified resources has been produced of the more than 13.5 billion short tons (billion metric tons) that are estimated to occur in these coal provinces. Alaskan coal resources have low sulfur content (averaging 0.2-0.4 percent) compared to the coal in the conterminous United States. This low-sulfur coal is within or below the minimum value mandated by the 1990 Clean Air Act amendments. The extremely large identified coal resources are located near existing infrastructure, which should aid in their development, transportation, and marketing. The short distance of these resources to countries in the western Pacific would appear to make them more marketable there than in the conterminous United States.

An untapped resource is coalbed methane. With more than 5,500 billion short tons (5,012 billion metric tons) of combined coal resources of Alaska coal, the in-place gas resource is an exceedingly large volume. A large part of the measured, indicated, inferred, and hypothetical coal resources, about 5,482 billion short tons ( 4,972 billion metric tons), is in the Northern Alaska-Slope and Southern Alaska-Cook Inlet coal provinces where in-place and planned infrastructure (pipelines, highways, and so on) can assist in the transportation and marketability of coalbed gas. The shallow depths to a large portion of the methane-bearing coal beds in onshore areas make the gas more accessible for future development.

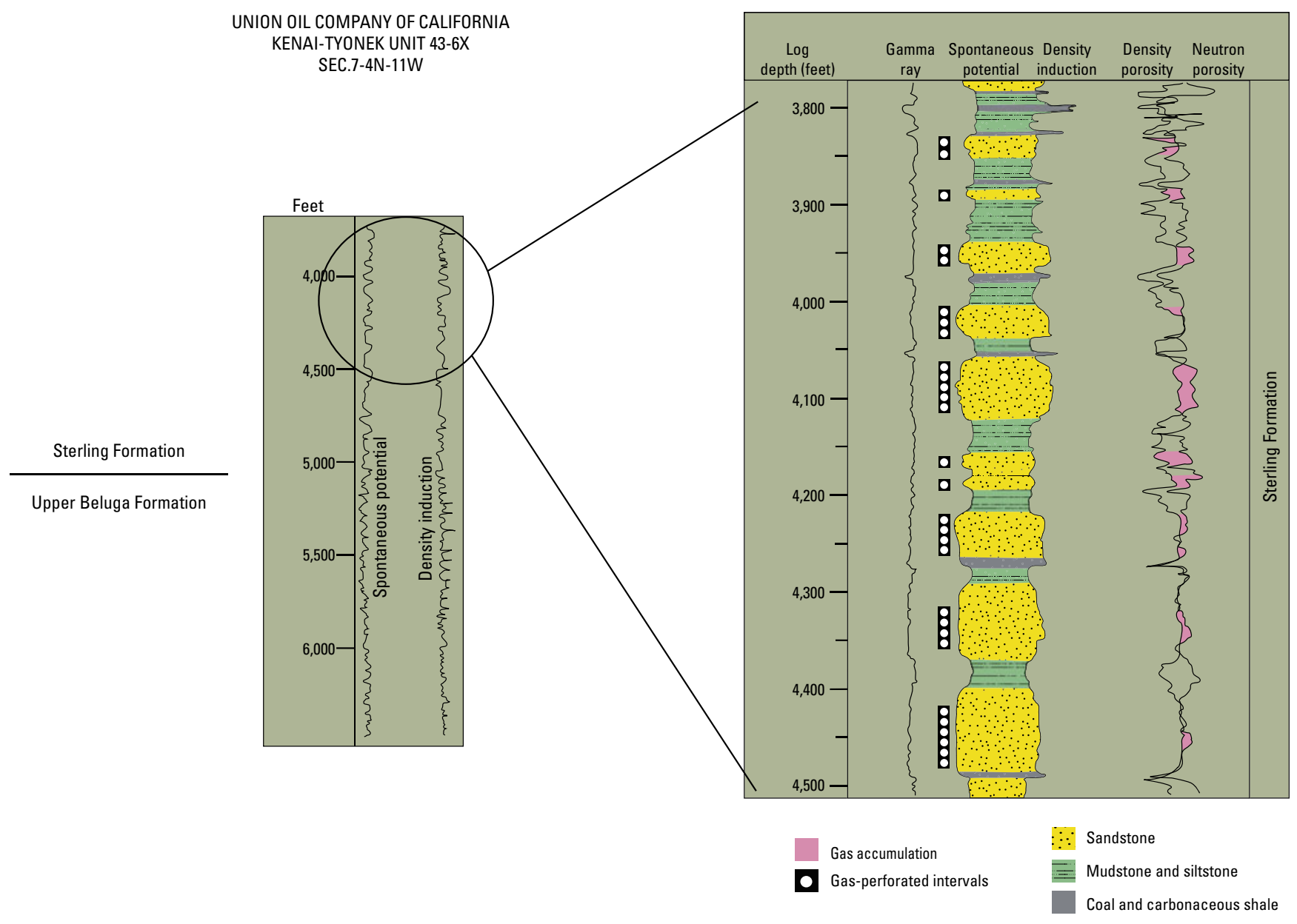

Figure 111. Facies profile of the lower part of the Sterling Formation and accompanying downhole logs showing horizons of gas accumulation. The Sterling facies include fluvial-channel sandstones and flood-plain mudstones and siltstones. 


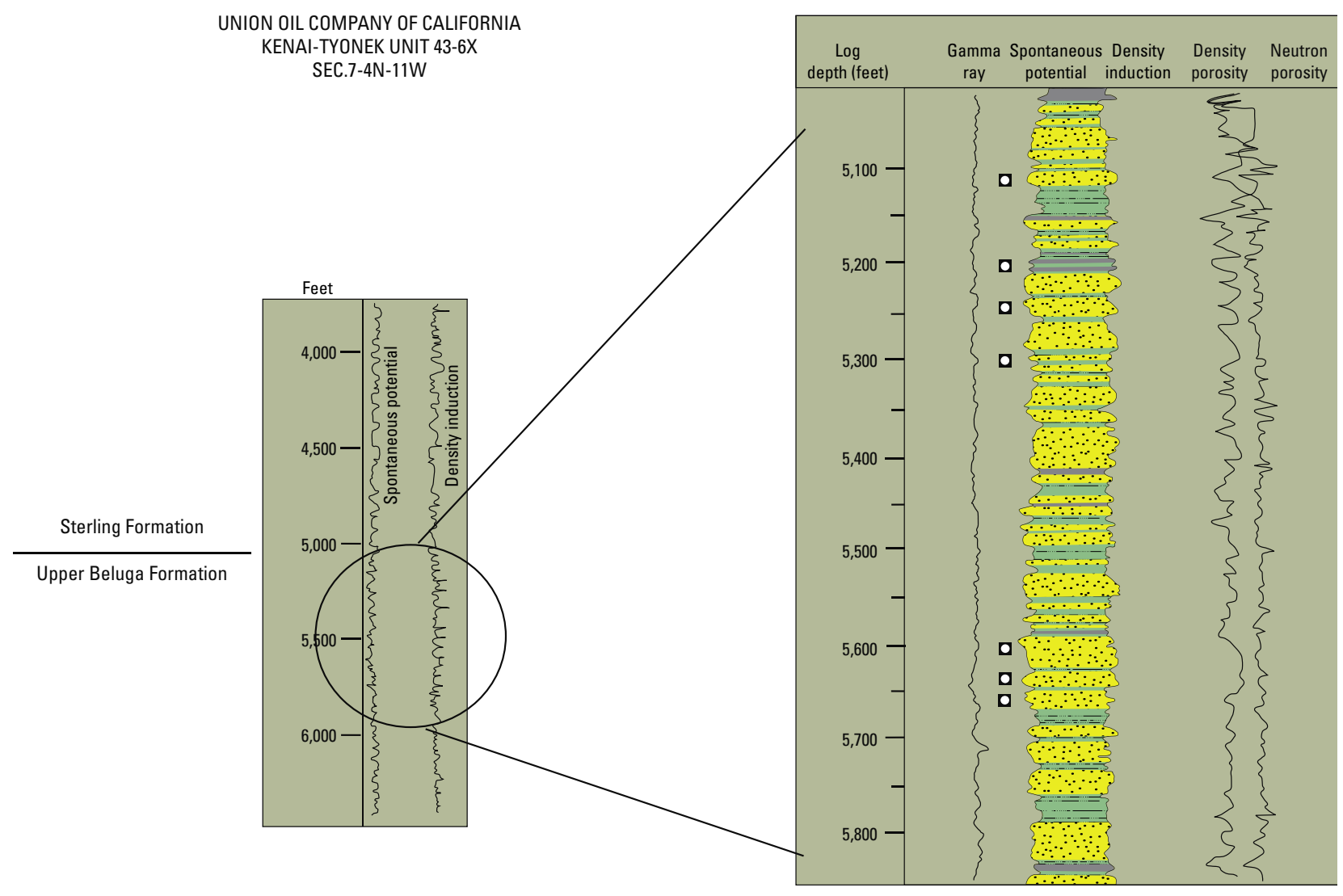

Figure 112. Facies profile of the upper part of the Beluga Formation and accompanying downhole logs showing horizons of gas-perforated intervals.

\section{Acknowledgments}

The authors acknowledge Heather Mitchell, Dean Hancock, Jennifer Goldsmith, and Steve Dunn for their assistance in generation of the digital illustrations for this paper. The data for this study were collected from 1988 to 2002 with the help of numerous geologists, too many to mention here, from the U.S. Geological Survey, Alaska Department of Natural Resources Division of Oil and Gas and Division of Geological and Geophysical Surveys, Alaska Geologic Materials Center, and Bureau of Land Management. Funding for part of this study from the Division of Oil and Gas is very much appreciated. Finally, we thank the Usibelli Coal Mine Inc., Beluga, Diamond Alaska, and Placer Dome coal companies, ARCO Alaska Inc. and International ARCO, and Marathon Oil Company, Anchorage, Alaska and Littleton, Colorado, for sharing information and permission to describe their core data.

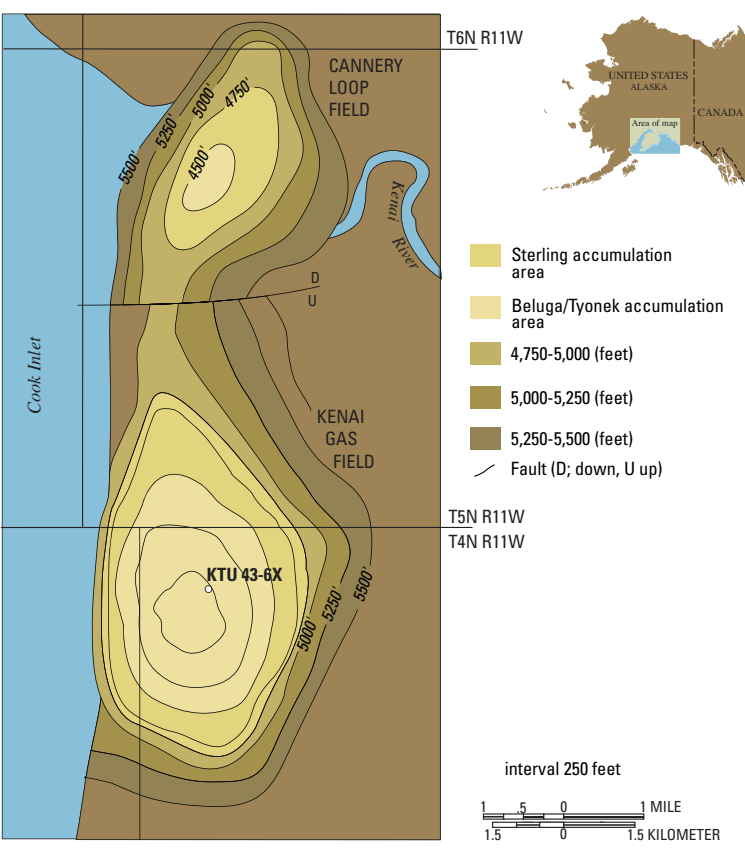

Figure 113. Location map of the Kenai gas field in the Kenai Peninsula. Gas accumulations in the Beluga and Sterling Formations occur on a doubly-plunging anticline. KTU 43$6 \mathrm{X}$ is the well described in figures 110 and 111. 
Figure 114. Basinwide and vertical variations of vitrinite reflectance (Ro) values in the Cook Inlet Basin. Modified from Johnsson and others (1993).

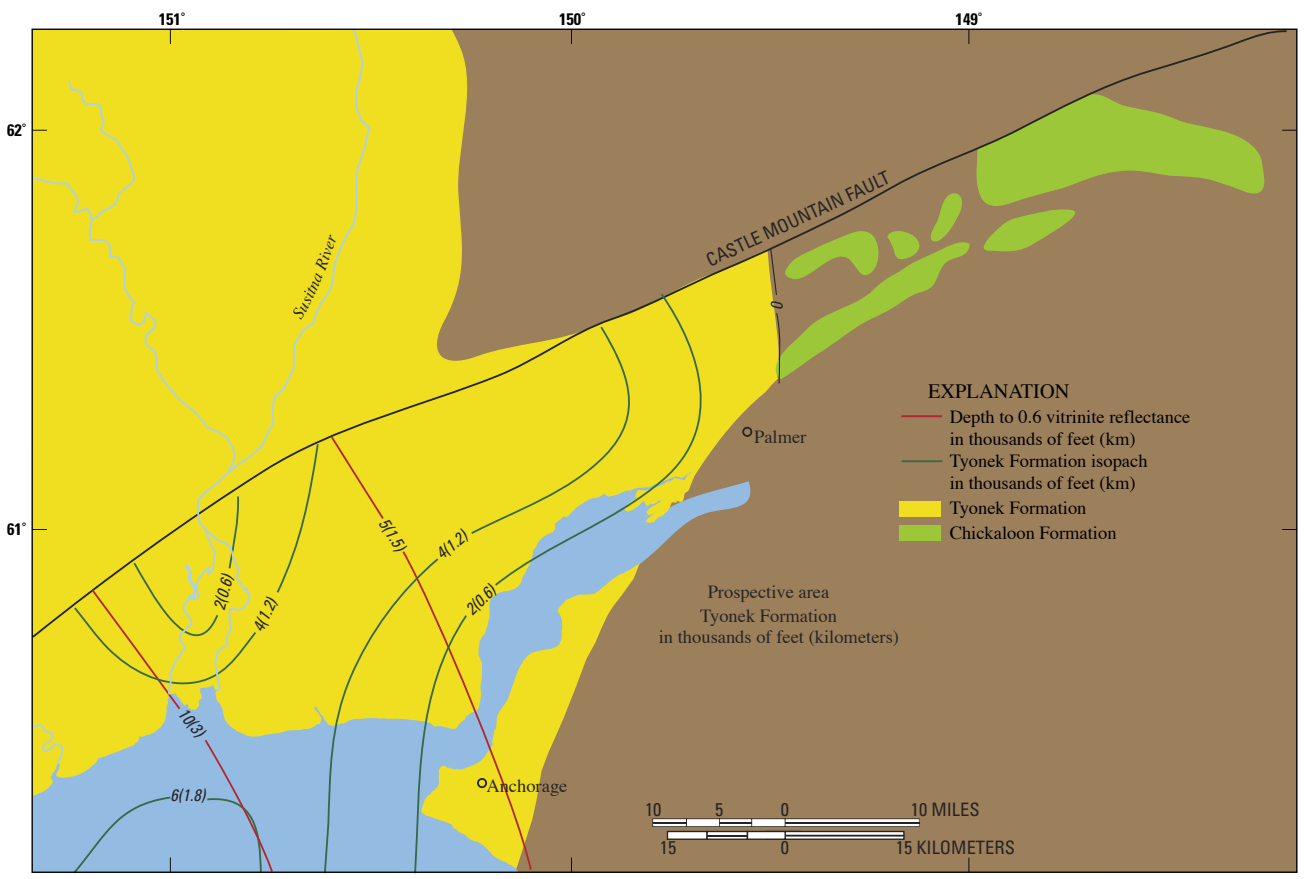

Figure 115. Coalbed methane prospect area and depths to vitrinite reflectance values of 0.6 percent superimposed on the thickness isopach of the Tyonek Formation south of the Castle Mountain fault in the northeastern part of the Cook Inlet. Adopted from Smith (1995).

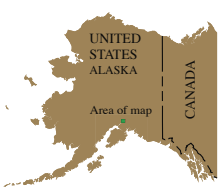




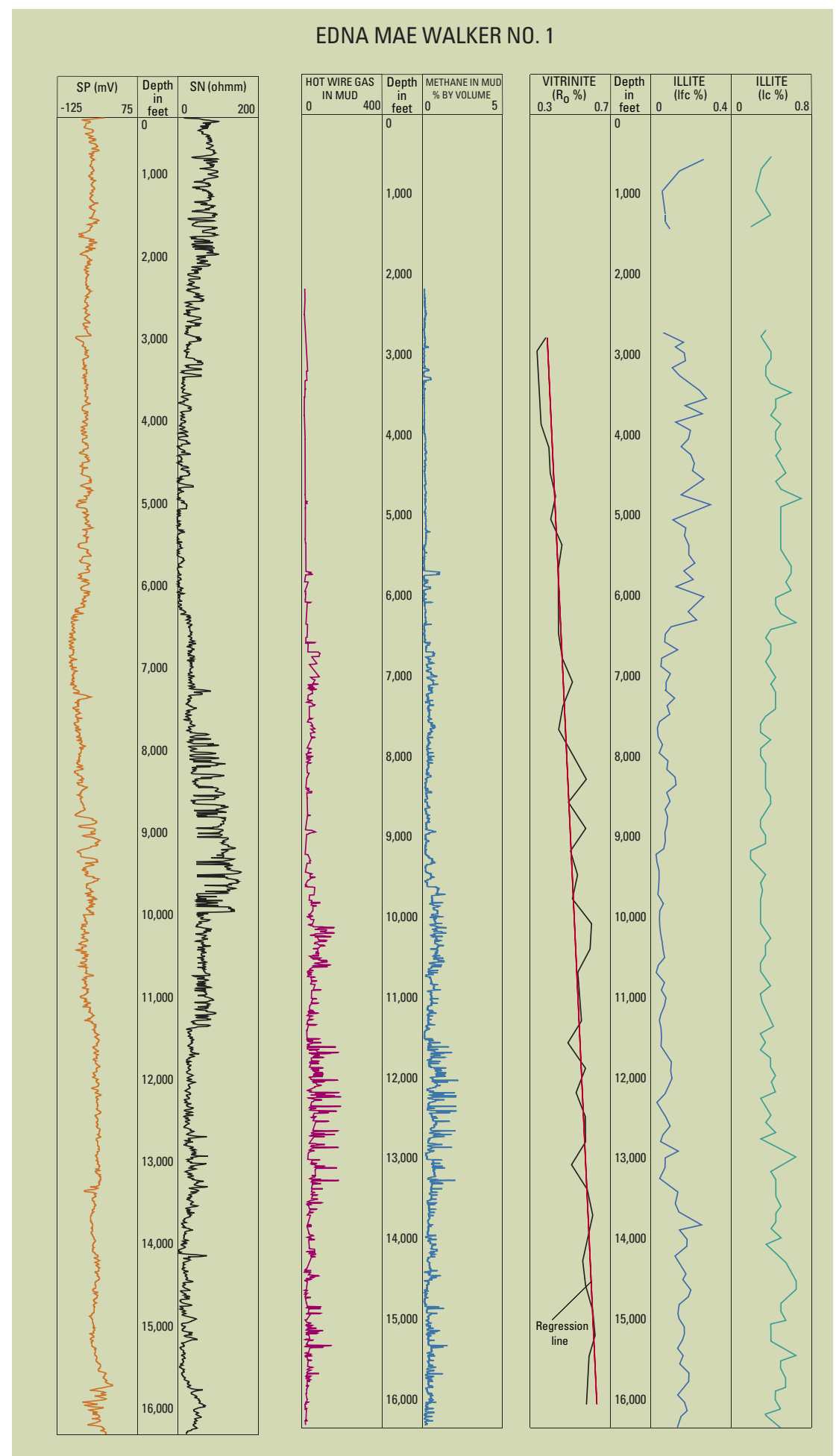

Figure 116. Downhole geophysical logs, hot wire total gas and methane contents, vitrinite reflectance values, and illite diagenetic values in the Edna Mae Walker drill hole. $\mathrm{SP}=$ spontaneous potential; $\mathrm{mV}=$ millivolt; $\mathrm{SN}=$ sonic; $\mathrm{Ro}=$ vitrinite reflectance; $\%=$ percent. Ipf=illite peak profile at 10 angstroms; Ic= illite crystallinity. Modified from Shi-Ming (1996). 


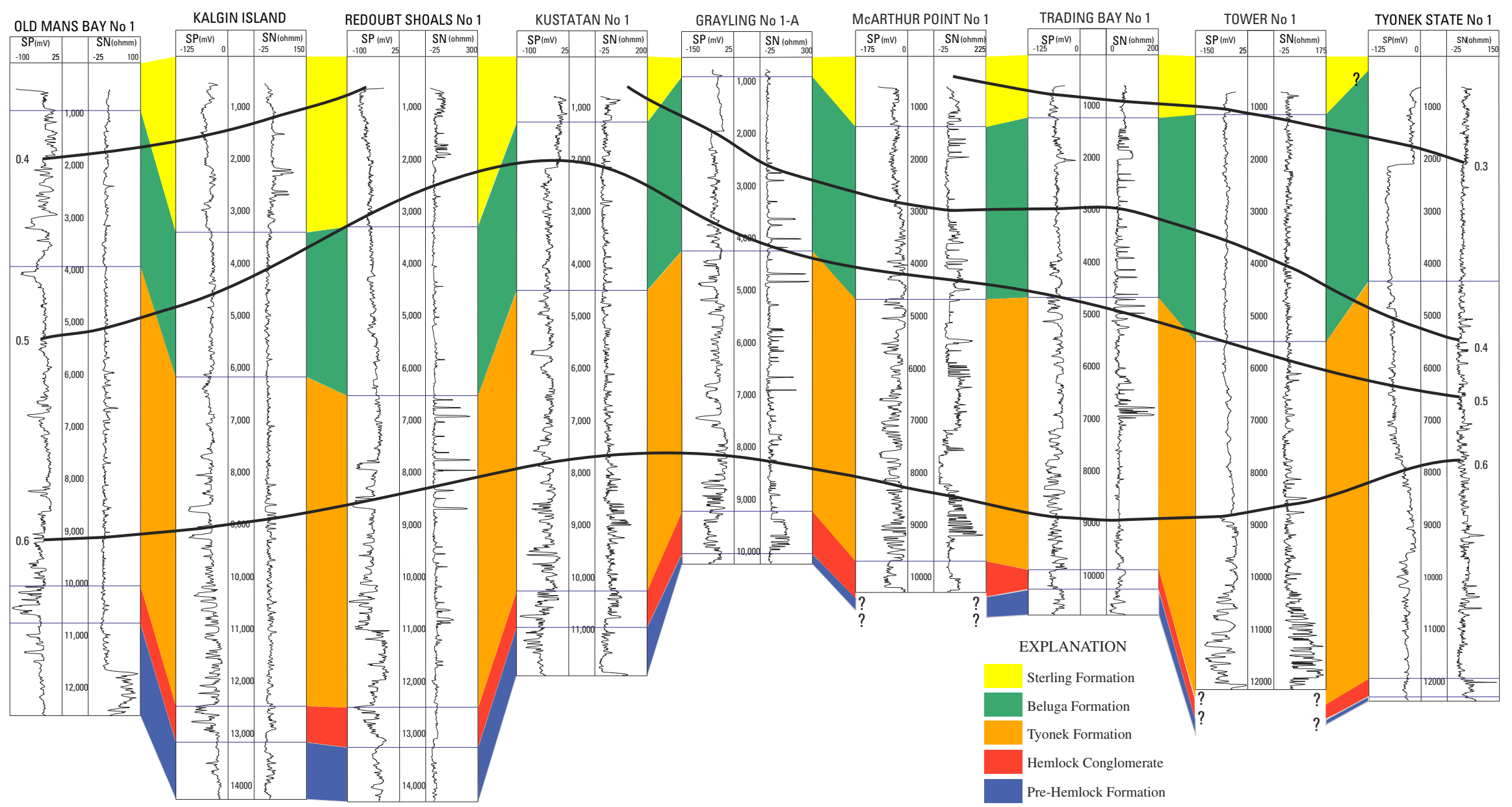

Figure 117. Stratigraphic cross section of the Kenai Group in the offshore Cook Inlet Basin with superimposed vitrinite reflectance values. See figure 58 for location. 


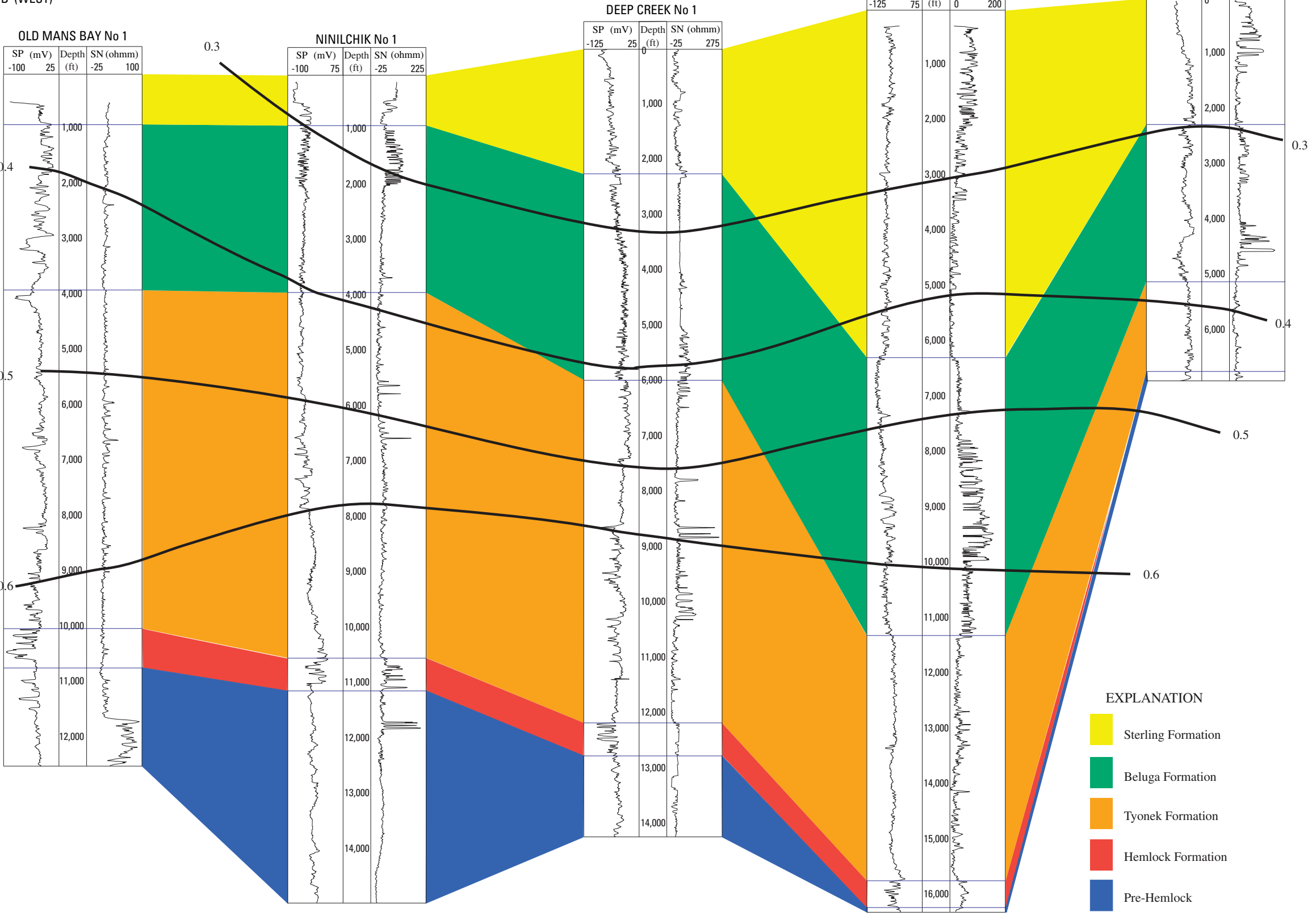

SECTION B TO B' (WEST TO EAST SOUTH PART OF STUDY AREA)

Figure 118. Stratigraphic cross section of the Kenai Group in the onshore Cook Inlet Basin with superimposed vitrinite reflectance values. See figure 58 for location. 


\section{References Cited}

Adkison, W.L., Kelley, J.S., and Newman, K.R., 1975, Lithology and palynology of Tertiary rocks exposed near Capps Glacier and along Chuitna River, Tyonek quadrangle, southern Alaska: U.S. Geological Survey Open-File Report 75-71, 57 p., 1 plate.

Affolter, R.H., Simon, F.H., and Stricker, G.D., 1981, Chemical analyses of coal from the Healy, Kenai, Seldovia, and Utukok River 1:250,000 quadrangles, Alaska: U.S. Geological Survey Open-File Report 81-654, 88 p.

Affolter, R.H., and Stricker, G.D., 1986, Variations in element distribution of coal from the Usibelli mine, Healy, Alaska, in Rao, P.D., ed., Focus on Alaska coal 1986, proceedings of the conference: Fairbanks, University of Alaska Mineral Industry Research Laboratory Report 72, p. 91-99.

Affolter, R.H., and Stricker, G.D., 1987a, Geochemistry of coal from the Cretaceous Corwin and Chandler Formations, National Petroleum Reserve in Alaska (NPRA), in Tailleur, I. L., and Weimer, Paul, eds., Alaskan North Slope geology: Bakersfield, Calif., Pacific Section, Society of Economic Paleontologists and Mineralogists Special Publication 50, p. 217-224.

Affolter, R.H., and Stricker, G.D., 1987b, Offshore Alaska coal, in Scholl, D.W., Grantz, Arthur, and Vedder, J.G., eds., Geology and resource potential of the continental margin of western North America and adjacent ocean basins - Beaufort Sea to Baja California: Houston, Texas, Circum-Pacific Council for Energy and Mineral Resources, Earth Science Series, v. 6, p. 639-647.

Affolter, R.H., and Stricker, G.D., 1988, Effects of paleolatitude on coal quality - a model for organic sulfur distribution in United States: American Association of Petroleum Geologists Bulletin, v. 73, p. 326.

Affolter, R.H., and Stricker, G.D., 1990, Paleolatitude-A primary control on the sulfur content in United States coals, in Carter, L.M.H., ed., USGS Research on Energy Resources 1990: U.S. Geological Survey Circular 1060, p. 1.

Affolter, R.H., and Stricker, G.D., 1994, Quality of Alaskan coal B-A statewide summary, in Rao, P.D., and Walsh, D.E., eds., Focus on Alaska coal 1993, (proceedings of the conference): Fairbanks, University of Alaska Mineral Industry Research Laboratory Report 94, p. 190-227.

Affolter, R.H., Stricker, G.D., Flores, R.M., and Stanley, R.G., 1994, Geochemical evaluation of coal from the Tertiary Usibelli Group, Usibelli coal mine, Alaska B one of the lowest sulfur coals mined in the United States, in Rao, P.D., and Walsh, D.E., eds., Focus on Alaska coal 1993, proceedings of the conference: Fairbanks, University of Alaska Mineral Industry Research Laboratory Report 94, p. 167-182.
Ahlbrandt, T.S., Huffman, A.C., Jr., Fox, J.E., and Pasternak, Ira, 1979, Depositional framework and reservoir quality studies of selected Nanushuk Group outcrops, North Slope, Alaska, in Ahlbrandt, T.S., ed., Preliminary geologic, petrologic, and paleontologic results of the study of Nanushuk Group rocks, North Slope, Alaska: U.S. Geological Survey Circular 794, p. 14-31.

Alaska Department of Natural Resources, Division of Oil and Gas, 1997, Historical and projected oil and gas consumption: Department of Natural Resources, Division of Oil and Gas, 67 p.

Alaska Geological Society, 1969a, North to south stratigraphic correlation section, Kalgin Island to Beluga River, Cook Inlet Basin, Alaska: Prepared by Alaska Geological Society Stratigraphic Committee Year 1968-69, 1 sheet.

Alaska Geological Society, 1969b, Northwest to southeast stratigraphic correlation section, Drift River to Anchor River, Cook Inlet Basin, Alaska: Prepared by Alaska Geological Society Stratigraphic Committee Year 1968-69, 1 sheet.

Alaska Geological Society, 1969c, South to north stratigraphic correlation section, Anchor Point to Campbell Point, Cook Inlet Basin, Alaska: Prepared by Alaska Geological Society Stratigraphic Committee Year 1968-69, 1 sheet.

Averitt, Paul, 1975, Coal resources of the United States, January 1, 1974; U.S. Geological Survey Bulletin 1412, 131 p.

Barnes, F.F., 1962, Variation in rank of Tertiary coals in the Cook Inlet basin, Alaska: U.S. Geological Survey Professional Paper 450-C, p. C14-C16.

Barnes, F.F., 1966, Geology and coal resources of the BelugaYentna region, Alaska: U.S. Geological Survey Bulletin 1202-C, p. CI-C34, plates 1-7.

Barnes, F.F., 1967a, Coal resources of Alaska: U.S. Geological Survey Bulletin 1242-B, B1-B36, plate 1.

Barnes, F.F., 1967b, Coal resources of the Cape LisburneColville River region, Alaska: U.S. Geological Survey Bulletin 1242-E, p. EI-E37.

Barnes, F.F., and Cobb, E.H., 1959, Geology and coal resources of the Homer District, Kenai coal field, Alaska: U.S. Geological Survey Bulletin 1058-F, p. 217-258, plates 17-28.

Barnes, F.F., and Payne, T.G., 1956, The Wishbone Hill District, Matanuska coal field, Alaska: U.S. Geological Survey Bulletin 1016, 88 p., 20 plates.

Barnes, F. F., and Sokol, D., 1959, Geology and coal resources of the Little Susitna District, Matanuska coal field, Alaska: U.S. Geological Survey Bulletin 1058-D, p. 121-138, plates 7-11. 
Beikman, H.M., 1980, Geologic map of Alaska: U.S. Geological Survey, scale 1:2,500,000.

Belowich, M.A., 1987, Basinal trends in coal, petrographic, and elemental composition with implications toward seam correlation, Jarvis Creek coal field, Alaska, in Rao, P.D., ed., Focus on Alaska coal: 1986 Proceedings of the conference, Fairbanks, University of Alaska Mineral Industry Research Laboratory Report 72, p. 300-335.

Belowich, M.A., 1994, Geology, mine development, and marketing for Evan Jones coal, in Rao, P.D., and Walsh, D.E., eds., Focus on Alaska coal: 1993 Proceedings of the conference, Fairbanks, University of Alaska Mineral Industry Research Laboratory Report 94, p. 132-139.

Bird, K.J., and Andrews, Jack, 1979, Subsurface studies of the Nanushuk Group, North Slope, Alaska, in Ahlbrandt, T.S., ed., Preliminary geologic, petrologic, and paleontologic results of the study of Nanushuk Group rocks, North Slope, Alaska: U.S. Geological Survey Circular 794, p. 32-41.

Blumer, J.W., 1981, Review of Mobil coal leases - Yentna region, Alaska, in Rao, P.D., and Wolff, E.N., eds., Focus on Alaska's coal '80 (conference proceedings), Fairbanks, University of Alaska, October 21-23, 1980: University of Alaska Mineral Industry Research Laboratory Report no. 50 , p. 122-126.

Brew, D.A., 1994, Latest Mesozoic and Cenozoic magmatism in southeastern Alaska, in Plafker, G., and Berg, H.C., eds., The geology of Alaska: Geological Society of America, The geology of North America, v. G-1, p. 621-656.

Brimberry, D.L., Gardner, P.S., McCullough, M.L., and Trudell, S.E., 1997, Kenai field, the Kenai Peninsula's largest gas field, in Karl, S.M., Vaughn, N.R., and Ryherd, T.J., eds., 1997 Guide to the geology of the Kenai Peninsula, Alaska: Alaska Geological Society, p. 28-35.

Brosgé, W.P., and Whittington, C.L., 1966, Geology of the Umiat-Maybe Creek region, Alaska: U.S. Geological Survey Professional Paper 303-H, p. H501-H638.

Buckingham, M.L., 1985, Stratigraphy, petrology, and depositional environments of Upper Cretaceous and Lower Tertiary Sabbath Creek section, Arctic National Wildlife Refuge (ANWR), Alaska: American Association of Petroleum Geologists Bulletin, v. 69, no. 4, p. 659.

Buckingham, M.L. 1987, Fluvio-deltaic sedimentation patterns of the upper Cretaceous to lower Tertiary Jago River Formation, Arctic National Wildlife Refuge (ANWR), northeastern Alaska, in Tailleur, I.L. and Weimer, Paul, eds., Alaskan North Slope geology, the Pacific section: Society of Economic Paleontologists and Mineralogists and Alaska Geological Society, v. 1, p. 529-540.
Buffler, R.T., and Triplehorn, D.M., 1976, Depositional environments of the Tertiary coal-bearing group, central Alaska, in Miller, T.P., ed., Proceedings of the Alaska Geological Society Symposium held April 2-4, 1975, Anchorage: Alaska Geological Society, p. H1-H10.

Bundtzen, T.K., Eakins, G.R., Green, C.B., and Lueck, L.L., 1986, Alaska's mineral industry, 1985: Alaska Division of Geological and Geophysical Surveys Special Report 39, 68 p.

Burk, C.A., 1965, Geology of the Alaska Peninsula-island arc and continental margin: Geological Society of America Memoir, v. 99, p. 1-250.

Calderwood, K.W., and Fackler, W.C., 1972, Proposed stratigraphic nomenclature for Kenai Group, Cook Inlet basin, Alaska: American Association of Petroleum Geologists Bulletin, v. 56, p. 739-754.

Callahan, J.E., 1979, Clathrates associated with coals, Workshop on clathrates (gas hydrates) in the National Petroleum Reserve, July 17, 1979: U.S. Geological Survey Open-File Report 81-1298, p. 9-10.

Callahan, J.E., and Sloan, E. G., 1978, Preliminary report on analyses of Cretaceous coals from northwestern Alaska: U.S. Geological Survey Open-File Report 78-319, 29 p., 1 plate.

Capps, S.R., 1927, Geology of the Upper Matanuska Valley, Alaska: U.S. Geological Survey Bulletin 791, 92 p., 16 plates.

Chapin, Theodore, 1920, Mining developments in the Matanuska Coal Field: U.S. Geological Survey Bulletin 712, p. 131-167, plates 4-6.

Chapman, R.M., and Sable, E.G., 1960, Geology of the Utukok-Corwin region, northwestern Alaska: U.S. Geological Survey Professional Paper 303-C, 167 p.

Clark, P.R., 1973, Transportation economics of coal resources of northern slope coal fields, Alaska: Anchorage, University of Alaska Mineral Industry Research Laboratory Report 31, $134 \mathrm{p}$.

Claypool, G.E., and Magoon, L.B., 1988, Oil and gas source rocks in the National Petroleum Reserve in Alaska: U.S. Geological Survey Professional Paper 1399, p. 451-481.

Clough, J.G., Barker, C.E., and Scott, A.R., 2000, Alaska methane remains untapped: American Association of Petroleum Geologists, Explorer, August, 2000, v. 21, no. 8, p. 54-55.

Collett, T.S., 1993, Natural gas hydrates of the Prudhoe Bay and Kuparuk River area, North Slope, Alaska: American Association of Petroleum Geologists Bulletin, v. 77, p. 793-812. 
Collier, A.J., 1906, Geology and coal resources of the Cape Lisburne region, Alaska: U.S. Geological Survey Bulletin 278,54 p.

Collins, F.R., 1959, Test wells, Square Lake and Wolf Creek areas, Alaska, with micropaleontology of Square Lake and Wolf Creek wells, northern Alaska, by H.R. Bergquest: U.S. Geological Survey Professional Paper 305-H, p. 423-484.

Conwell, C.N., and Triplehorn, D.M., 1976, High-quality coal near Point Hope, northwestern Alaska, in Short notes on Alaskan geology, 1976: Alaska Division of Geological and Geophysical Surveys Geologic Report 51, p. 31-35.

Csejety, Béla, Jr., Mullen, M.W., Cox, D.P., and Stricker, G.D., 1992, Geology and geochronology of the Healy quadrangle, south-central Alaska: U.S. Geological Survey Map I-1961, scale $1: 250,000,2$ sheets.

Dall, W.H., 1896, Coal and lignite in Alaska: U.S. Geological Survey Annual Report 17, p. 763-908.

Detterman, R.L., Plafker, George, Tysdal, R.G., and Hudson, Travis, 1976, Geology and surface features along part of the Talkeetna segment of the Castle Mountain Caribou fault system, Alaska: U.S. Geological Survey Miscellaneous Field Studies Map MF-738, scale 1:63,360.

Detterman, R.L., Reiser, H.N., Brosgé, W.P., and Dutro, J.T., Jr., 1975, Post-Carboniferous stratigraphy, northeastern Alaska: U.S. Geological Survey Professional Paper 886, 46 p.

Detterman, R.L., and Spicer, R.A., 1981, New stratigraphic assignment for rocks along Igilatvik (Sabbath) Creek, William O. Douglas Arctic Wildlife Refuge, Alaska, in Albert, N.R.D., and Hudson, Travis eds., The United States Geological Survey in Alaska - Accomplishments during 1979: U.S. Geological Survey Circular 823-B, p. B11-B12.

Dover, J.H., 1994, Geology of part of east-central Alaska, in Plafker, George, and Berg, H.C., eds., The geology of Alaska: Geological Society of America, The geology of North America, v. G-1, 153-204.

Dusel-Bacon, Cynthia, 1994, Metamorphic history of Alaska, in Plafker, George, and Berg, H.C., eds., The geology of Alaska: Geological Society of America, The geology of North America, v. G-1, p. 495-534.

Fassett, J.E., and Hinds, J.S., 1971, Geology and fuel resources of the Fruitland Formation and Kirkland Shale of the San Juan Basin, New Mexico and Colorado: U.S. Geological Survey Professional Paper 676, 76 p.

Ferrians, O.J., Jr., 1965, Permafrost map of Alaska: U.S. Geological Survey Miscellaneous Geologic Investigations Map I-445, scale 1:2,500,000.
Fisher, M.A., and Magoon, L.B., 1978, Geologic framework of Lower Cook Inlet, Alaska: American Association of Petroleum Geologists Bulletin, v. 62, p. 373-402.

Flores, R.M., 2000, Biogenic gas in low-rank coal-A viable and economic resource in the United States: Jakarta, Indonesia, June 19-20, 2000, Southeast Asian Coal Geology Conference Proceedings, p. 1-7.

Flores, R.M., and Cross, T.A., 1991, Cretaceous and Tertiary coals of the Rocky Mountains and Great Plains regions, in Gluskoter, H.J., Rice, D.D., and Taylor, R.B., eds., Economic geology, U.S.: Boulder, Colorado, Geological Society of America, The geology of North America, v. P-2, p. 547-571.

Flores, R.M., and Moore, T.A., in press, An evaluation of Southeast Asian peat mires as coal-forming models, in Moore, T.A., and Flores, R.M., eds., Southeast Asian Coal Geology -From peat to hydrocarbon generation: Developments in sedimentology series, Elsevier, Amsterdam.

Flores, R.M., Myers, M.D., Stricker, G.D., and Houle, J.A., 1999, Core lithofacies analysis and fluvio-tidal environments in the AK 94 CBM-1 well, near Wasilla, Alaska, in Dumoulin, J.A., and Gray, J.E., eds., Geologic studies in Alaska by the Geological Survey, 1997: U.S. Geological Survey Professional Paper 1614, p. 57-72.

Flores, R.M., and Stanley, R.G., 1995, Tertiary Usibelli Group of Suntrana, Alaska - Fluctuating base-level deposits in a fluvial pathway to Cook Inlet: Geological Society of America, Abstracts with Programs, v. 27, p. 18.

Flores, R.M., and Stricker, G.D., 1992, Some facies aspects of upper part of Kenai Group, southern Kenai Peninsula, in Bradley, D.C., and Dusel-Bacon, Cynthia, eds., Geologic studies in Alaska by the Geological Survey, 1991: U.S. Geological Survey Bulletin 2041, p. 160-170.

Flores, R.M., and Stricker, G.D., 1993a, Early Cenozoic depositional systems, Wishbone Hill District, Matanuska coal field, Alaska, in Dusel-Bacon, Cynthia, and Till, A.B., eds., Geologic studies in Alaska by the Geological Survey, 1992: U.S. Geological Survey Bulletin 2068, p. 101-117.

Flores, R.M., and Stricker, G.D., 1993b, Interfluve-channel facies models in the Miocene Beluga Formation near Homer, South Kenai Peninsula, Alaska, in Rao, P.D., and Walsh, D.E., eds., Focus on Alaska coal '86 (proceedings of the conference): Anchorage, May, 1993, University of Alaska Mineral Industry Research Laboratory Report 94, p. 140-166. 
Flores, R.M., and Stricker, G.D., 1993c, Reservoir framework architecture in the Clamgulchian type section (Pliocene) of the Sterling Formation, Kenai Peninsula, Alaska, in DuselBacon, Cynthia, and Till, A.B., eds., Geologic studies in Alaska by the Geological Survey, 1992: U.S. Geological Survey Bulletin 2068, p. 118-129.

Flores, R.M., and Stricker, G.D., 1993d, Responses of coal splitting and associated drainage pattern to syntectonism in the Paleocene and Eocene Chickaloon Formation, Matanuska coal field, Alaska, in Rao, P.D., and Walsh, D.E., eds., Focus on Alaska coal '86 (proceedings of the conference): Anchorage, May, 1993, University of Alaska Mineral Industry Research Laboratory Report 94, p. 113-131.

Flores, R.M., Stricker, G.D., and Bader, L.R., 1997, Stratigraphic architecture of the Tertiary alluvial Beluga and Sterling Formations, Kenai Peninsula, in Karl, S.M., Vaughn, N.R., and Ryherd. T.J., eds., 1997 Guide to the geology of the Kenai Peninsula, Alaska: Alaska Geological Society, p. 36-53.

Flores, R.M., Stricker, G.D., and Bader, L.R., 1998, Predicting subsurface reservoir architecture of Sterling and Beluga fluvial sandstones from outcrop models, Kenai Peninsula, Alaska, in Karl, S.M., ed., Anchorage, April, 1993, Cutting edge in Alaska: The Geological Society of Alaska, p. 7.

Flores, R.M., Stricker, G.D., and Roberts, S.B., 1994, Miocene coal-bearing strata of the Tyonek Formation-Braidedstream deposits in the Chuit Creek-Chuitna River drainage basin, southern Alaska, in Till, A.B., and Moore, T.E., eds., Geologic studies in Alaska by the Geological Survey, 1993: U.S. Geological Survey Bulletin 2107, p. 95-114.

Flores, R.M., Stricker, G.D., and Stiles, R.B., 1997, Tidal influence on deposition and quality of coals in the Miocene Tyonek Formation, Beluga coal field, upper Cook Inlet, Alaska, in Dumoulin, J.A., and Gray, J.E., eds., Geologic studies in Alaska by the Geological Survey, 1995: U.S. Geological Survey Professional Paper 1574, p. 95-114.

Germer, D.E., 1986, Geology, mine plan, and potential utilization of coal from the Wishbone Hill district, Matanuska field, Alaska, in Rao, P.D., ed., Focus on Alaska coal '86 (proceeding of conference): Anchorage, October, 1986, University of Alaska Mineral Industry Research Laboratory Report No. 72, p. 229-237.

Grantz, Arthur, Holmes, M.L., and Kososki, B.A., 1975, Geologic framework of the Alaskan continental terrace in the Chukchi and Beaufort Seas, in Yorath, C.J., Parker, E.R., and Glass, D.J., eds., Canada's continental margins and offshore petroleum exploration: Canada Society of Petroleum Geologists Memoir 4, p. 669-700.

Grantz, Arthur, and Jones, D.L., 1960, Stratigraphy and age of the Matanuska Formation: U.S. Geological Survey Professional Paper 400-13, p. B347-B351.
Grantz, Arthur, May, S.D., and Hart, P.E., 1994, Geology of the Arctic continental margin of Alaska, in Plafker, George, and Berg, H.C., eds., The geology of Alaska: Geological Society of America, The geology of North America, v. G-1, p. $17-48$.

Green, C.B., and Bundtzen, T.K., 1989, Summary of Alaska's mineral industry in 1988: Alaska Division of Geological and Geophysical Surveys Public Data File 89-7, 6 p.

Gyrc, George, Patton, W.W., Jr., and Payne, T.G., 1951, Present Cretaceous stratigraphic nomenclature of northern Alaska: Journal Washington Academy Sciences, v. 41, p. 159-167.

Hartman, D.C., Pessel, G.H., and McGee, D.L., 1971, Preliminary report, Kenai Group of Cook Inlet, Alaska: Alaska Division of Geological and Geophysical Surveys Special Report 5, 4 p., 11 plates.

Hayes, J.B., Harms, J.C., and Wilson, T., Jr., 1976, Contrasts between braided and meandering stream deposits, Beluga and Sterling Formations (Tertiary), Cook Inlet, Alaska, in Miller, T.P., ed., Recent and ancient sedimentary environments in Alaska: Proceedings, Alaska Geological Society Symposium, April 2-4, 1975, Anchorage, Alaska Geological Society, p. J1-J27.

Hite, D. M., 1976, Some sedimentary aspects of the Kenai Group, Cook Inlet, Alaska, in Miller, T.P., ed., Recent and ancient sedimentary environments in Alaska: Proceedings, Alaska Geological Society Symposium, April 2-4, 1975, Anchorage, Alaska Geological Society, p. I1-I23.

Hopkins, D.M., 1951, Lignite deposits near Broad Pass Station, Alaska: U.S. Geological Survey Bulletin 963-E, p. 187-191, 1 plate.

Houston, W.S., 1994, Lower Tertiary stratigraphy in Katmai National Park, Alaska-A lithologic and petrographic study: Fort Collins, Colorado State University, Master's thesis, 244 p.

Huffman, A.C., Jr., Ahlbrandt, T.S., Pasternack, Ira, Stricker, G.D., and Fox, J.E., 1985, Depositional and sedimentologic factors affecting the reservoir potential of the Cretaceous Nanushuk Group, central North Slope, Alaska, in Huffman, A.C., Jr., ed., Geology of the Nanushuk Group and related rocks, central North Slope, Alaska: U.S. Geological Survey Bulletin 1614, p. 61-74.

Huffman, A.C., Jr., Ahlbrandt, T.S., and Bartsch-Winkler, Susan, 1988, Sedimentology of the Nanushuk Group, North Slope, Alaska, in Gryc, George, ed., Geology and exploration of the National Petroleum Reserve in Alaska, 1974 to 1982: U.S. Geological Survey Professional Paper 1399, p. 281-298. 
Huish, R., compiler, 1836, Voyages of Captain Beechey to the Pacific 1825-28 and of Captain Back to the Arctic Sea: London, William Wright, 704 p.

Husky Oil NPR Operations, Inc., 1982-1983, Geological reports of test wells in National Petroleum Reserve in Alaska: Unpublished reports of Husky Oil NPR Operations Inc. Copies of these reports are available for purchase from the National Geophysical and Solar-Terrestrial Data Center, NOAA, Boulder, Colorado 80303.

Jenden, P.I., and Kaplan, I.R., 1986, Comparison of microbial gases from the Middle America Trench and Scripps submarine canyon - Implications for the origin of natural gas: Applied Geochemistry, v. 1, p. 631-646.

Johnsson, M.J., Howell, D.G., and Bird, K.J., 1993, Thermal maturity patterns in Alaska-Implications for tectonic evolution and hydrocarbon potential: American Association of Petroleum Geologists Bulletin, v. 77, p. 1874-1903.

Johnsson, M.J., Pawlewicz, M.J., Harris, A.G., and Valin, Z.C., 1992, Vitrinite reflectance and conodont color alteration index data from Alaska: U.S. Geological Survey OpenFile Report 92-409, 3 disks.

Kelly, T.E., 1968, Gas accumulations in nonmarine strata, Cook Inlet Basin, Alaska, in Beebe, B.W., and Curtis, B.F., eds., Natural gases of North America: American Association of Petroleum Geologists Memoir 9, p. 49-64.

Kirschner, C.E., 1988, Map showing sedimentary basins of onshore and continental shelf areas, Alaska: U.S. Geological Survey Miscellaneous Investigations Series Map 1- 1873, scale 1:2,500,000.

Kirschner, C.E., and Lyon, C.A., 1973, Stratigraphic and tectonic development of Cook Inlet Petroleum Province, in Pitcher, M.G., ed., Arctic geology: American Association of Petroleum Geologists Memoir 19, p. 396-407.

Kremer, M.C., and Stadnicky, George, 1985, Tertiary stratigraphy of the Kenai Peninsula, Cook Inlet region, in Sisson, Alexander, ed., Guide to the geology of the Kenai Peninsula, Alaska: Alaska Geological Society, p. 24-42.

Magoon, L.B., Adkison, W.L., and Egbert, R.M., 1976, Map showing geology, wildcat wells, Tertiary plant fossil localities, K-Ar age dates, and petroleum operations, Cook Inlet Area, Alaska: U.S. Geological Survey Miscellaneous Investigations Series Map 1-1019, 3 sheets, scale 1:250,000.

Magoon, L.B., and Anders, D.E, 1990, Oil-source rock correlation using carbon isotope data and biological marker compounds, Cook Inlet, Alaska peninsula, Alaska: American Association of Petroleum Geologists Bulletin, v. 63, p. 711.
Magoon, L.B., and Bird, K.J., 1988, Evaluation of petroleum source rocks in the National Petroleum Reserve in Alaska, using organic-carbon content, hydrocarbon content, visual kerogen, and vitrinite reflectance, in Gryc, George, ed., Geology and exploration of the National Petroleum Reserve in Alaska, 1974 to 1982: U.S. Geological Survey Professional Paper 1399, p. 381-450.

Magoon, L.B., and Egbert, R.M., 1986, Framework geology and sandstone composition, in Magoon, L.B., ed., Geologic studies of the Lower Cook Inlet COST No. I Well, Alaska outer continental shelf: U.S. Geological Survey Bulletin 1596, p. 65-90.

Martin, G.C., 1915, The western part of Kenai Peninsula, in Martin, G.C., Johnson, B.L., and Grantz, Arthur, U.S., eds., Geology and mineral resources of Kenai Peninsula, Alaska: U.S. Geological Survey Bulletin 587, p. 41-112.

Martin, G.C., Johnson, B.L., and Grant, U.S., 1915, Geology and mineral resources of Kenai Peninsula, Alaska: U.S. Geological Survey Bulletin 587, 243 p.

McKee, C.R., Bumb, A.C., Way, S.C., Koenig, R.A., Reverand, J.M., and Brandenburg, C.F., 1986, Using permeability-vs-depth correlations to assess the potential for producing gas from coal seams: Gas Research Institute, Quarterly review of methane from coal seams technology, v. 4, p. 15-26.

McGee, D.L., and O'Connor, K.M., 1975, Cook Inlet Basin subsurface coal reserve study: Alaska Division of Geological and Geophysical Surveys Open-File Report 74, 24 p., 3 plates.

Merritt, R.D., 1984, Alaska's coal data base: Alaska Division of Geological and Geophysical Surveys Public-data File 85-22, $76 \mathrm{p}$.

Merritt, R.D., 1985, Review of coking phenomena in relation to an occurrence of prismatically fractured natural coke from the Castle Mountain mine, Matanuska Valley, Alaska: International Journal of Coal Geology, v. 4, p. 281-298.

Merritt, R.D., 1986, Paleoenvironmental and tectonic controls in major coal basins of Alaska, in Lyons, P.C., and Rice C.L., eds., Paleoenvironmental and tectonic controls in coalforming basins of the United States: Geological Society of America Special Paper 210, 173-200.

Merritt, R.D., 1987, Geology and coal resources of the Wood River field, Nenana Basin, in Rao, P.D., ed., Focus on Alaska's coal '86 (proceedings of the conference): Anchorage, October, 1986, University of Alaska Mineral Industry Research Laboratory Report No. 72, p.116-126. 
Merritt, R.D., and Belowich, M.A., 1984, Coal geology and resources of the Matanuska Valley, Alaska: Alaska Division of Geological and Geophysical Surveys Report of Investigations 84-24, 64 p., 3 plates.

Merritt, R.D., and Hawley, C.C., compilers, 1986, Map of Alaska's coal resources: Fairbanks, Alaska Division of Geological and Geophysical Surveys, scale 1:2,500,000.

Merritt, R.D., Lueck, L.L., Rawlinson, S.E., Belowich, M.A., Goff, K.M., Clough, J.G., and Reinick-Smith, L.M., 1987, Southern Kenai Peninsula (Homer District) coal resource assessment and mapping project-Final report: Alaska Division of Geological and Geophysical Surveys Public Data File $87-15,125$ p., 15 sheets.

Metz, P.A., 1981, Mining, processing, and marketing of coal from Jarvis Creek Field [abs.], in Rao, P. D., and Wolff, E. N., eds., Focus on Alaska's coal '80 (conference proceedings, University of Alaska, Fairbanks, October 21-23, 1980): University of Alaska Mineral Industries Research Laboratory Report no. 50, p. 171.

Molenaar, C.M., 1981, Depositional history and seismic stratigraphy of Lower Cretaceous rocks, National Petroleum Reserve in Alaska and adjacent areas: U.S. Geological Survey Open-File Report 81-1084, 42 p.

Molenaar, C.M., 1983, Depositional relations of Cretaceous and Lower Tertiary rocks, northeastern Alaska: American Association of Petroleum Geologists Bulletin, v. 67, p. 1066-1080.

Molenaar, C.M., 1985, Subsurface correlations and depositional history of the Nanushuk Group and related rocks, North Slope, Alaska, in Huffman, A.C., Jr., ed., Geology of the Nanushuk Group and related rocks, North Slope, Alaska: U.S. Geological Survey Bulletin 1614, p. 37-60.

Molenaar, C.M., Bird, K.J., and Collett, T.S., 1986, Regional correlation sections across the North Slope of Alaska: U.S. Geological Survey Miscellaneous Field Study Map MF1907, 1 sheet.

Molenaar, C.M., Kirk, A.R., Magoon, L.B., and Huffman, A.C., Jr., 1984, Twenty-two measured sections of Cretaceous-lower Tertiary rocks, eastern North Slope, Alaska: U.S. Geological Survey Open-File Report 84-695, 19 p.

Myers, M.D., Flores, R.M., Stricker, G.D., and Houle, J.A., 1998, Depositional environments and reservoir characteristics of the Tertiary Tyonek Formation, Upper Cook Inlet, Alaska, in Karl, S.M., ed., Cutting edge in Alaska: The Alaska Geological Society, p. 20.

Neavel, R.C., 1981, Origin, petrography, and classification of coal, in Elliott, M.A., ed., Chemistry of coal utilization (second supplementary volume): New York, Wiley-Interscience, p. $91-158$.
Nokleberg, W.J., Plafker, George, and Wilson, F.H., 1994, Geology of south-central Alaska, in Plafker, George, and Berg, H.C., eds., The geology of Alaska: Geological Society of America, The geology of North America, v. G-1, p. 311-366.

Palmer, I.F., Bolm, J.G., Maxey, L.R., and Lyle, W.M., 1979, Petroleum source rock and reservoir quality data from outcrop samples, onshore North Slope of Alaska east of Prudhoe Bay: U.S. Geological Survey Open-File Report 79-1634, 52 p.

Plafker, George, 1987, Regional geology and potential of the northern Gulf of Alaska continental margin, in Scholl, D.W., Grantz, Arthur, and Vedder, J.G., eds., Geology and resource potential of the continental margin of western North America and adjacent ocean basins - Beaufort Sea to Baja California: Houston, Texas, Circum-Pacific Council for Energy and Mineral Resources, Earth Science Series, v. 6, p. 229-268.

Plafker, George, and Berg, H.C., 1994, Introduction, in Plafker, George, and Berg, H.C., eds., The geology of Alaska: Geological Society of America, The geology of North America, v. G-1, p. 1-16.

Ramsey, J.P., 1981, Geology-coal resources and mining plan for the Chuitna River field, Alaska, in Rao, P.D., and Wolff, E.N., eds., Focus on Alaska's coal '80 (conference proceedings, University of Alaska, Fairbanks, October 21-23, 1980): University of Alaska, Mineral Industries Research Laboratory Report no. 50, p. 111-121.

Rao, P.D., 1980, Petrographic, mineralogical and chemical characterization of certain Arctic Alaskan coals from the Cape Beaufort region: Fairbanks, University of Alaska Mineral Industry Research Laboratory Report No. 44, 66 p.

Rao, P.D., and Smith, J.E., 1986, Characterization of Chuitna coal from deep drill core with possible applications to seam correlation, in Rao, P.D., ed., Focus on Alaska's coal '86 (conference proceedings, University of Alaska, Fairbanks, October 27-30, 1986): University of Alaska, Mineral Industries Research Laboratory Report no. 72, p. 157-182.

Rao, P.D., and Wolff, E.N., 1981, Petrological, mineralogical, and chemical characterizations of certain Alaskan coals and washability products, in Rao, P.D., and Wolff, E.N., eds., Focus on Alaska's coal '80 (conference proceedings, University of Alaska, Fairbanks, October 21-23, 1980): University of Alaska, Mineral Industries Research Laboratory Report No. 50, p. 194-235.

Rawlinson, S.E., 1984, Environments of deposition, paleocurrents, and provenance of Tertiary deposits along Kachemak Bay, Kenai Peninsula, Alaska: Sedimentary geology, v. 38, p. 421-442. 
Reed, B.L., and Nelson, S.W., 1980, Geologic map of the Talkeetna quadrangle, Alaska: U.S. Geological Survey Miscellaneous Investigations Series Map I-1174, scale $1: 250,000,15 \mathrm{p}$.

Rice, D.D., 1993, Composition and origins of coalbed gas, in Law, B.E., and Rice, D.D., eds., Hydrocarbons from coal: American Association Petroleum Geologists Studies in Geology \#38, p. 159-202.

Rice, D.D., and Claypool, G.E., 1981, Generation, accumulation, and resource potential of biogenic gas: American Association of Petroleum Geologists Bulletin, v. 65, p. 5-25.

Roberts, S.B., 1991, Cross section showing subsurface coal beds in the Sagavanirktok Formation, vicinity of Prudhoe Bay, east-central North Slope, Alaska: U.S. Geological Survey Coal Investigations Map C-139A, 1 sheet.

Roberts, S.B., Stricker, G.D., and Affolter, R.H., 1992, Reevaluation of coal resources in the Late Cretaceous-Tertiary Sagavanirktok Formation, North Slope, Alaska, in Bradley, D.C., and Ford, A.B., eds., Geologic studies in Alaska by the Geological Survey, 1990, U.S. Geological Survey Bulletin 1999, p. 196-203.

Roehler, H.W., and Stricker, G.D., 1979, Stratigraphy and sedimentation of the Torok, Kukpowruk, and Corwin Formations in the Kokolik-Utukok River region, National Petroleum Reserve in Alaska: U.S. Geological Survey Open-File Report 79-995, 80 p.

Ryer, T.A., 1981, Deltaic coals of Ferron Sandstone Member of Mancos Shale-Predictive model for Cretaceous coalbearing strata of Western Interior: Geological Society of America Bulletin, v. 65, p. 2323-2340.

Sable, E.G., and Stricker, G.D., 1987, Coal in the National Petroleum Reserve in Alaska (NPRA) - Framework geology and resources, in Tailleur, I.L., and Weimer, Paul, eds., Alaskan North Slope geology: Bakersfield, Calif., Pacific Section, Society of Economic Paleontologists and Mineralogists Special Publication 50, p. 195-215.

Sanders, R.B., 1976, Geology and coal resources of the Bering River field, in Rao, P.D., and Wolff, E.N., eds., Focus on Alaska's coal '75 (conference proceedings, University of Alaska, Fairbanks, October 15-17, 1975): University of Alaska Mineral Industries Research Laboratory Report no. 37, p. 54-58.

Sanders, R.B., 1981, Coal resources of Alaska, in Rao, P.D., and Wolff, E.N., eds., Focus on Alaska's coal ' 80 (conference proceedings, University of Alaska, Fairbanks, October 21-23, 1980): University of Alaska Mineral Industries Research Laboratory Report no. 50, p. 11-31.
Schopf, J.M., 1956, A definition of coal: Littleton, Colo., Economic geology, Bulletin of the Society of Economic Geologists, v. 51, p. 521-527.

Schrader, J.M., 1904, A reconnaissance in northern Alaska, across the Rocky Mountains, along Koyukuk, John, Anaktuvuk, and Colville Rivers, and the Arctic Coast to Cape Lisburne, in 1901: U.S. Geological Survey Professional Paper 20, 139 p., map.

Selleck, B.W., and Panuska, Bruce, 1983, Sedimentological models for the coal-bearing group (Oligocene-Miocene), central Alaska Range [abs.] Geological Society of America Abstracts with Program, v. 15, no. 6, p. 683.

Shi-Ming, Ma, 1996, Clay geology, provenance, and tectonics of Tertiary basins in Alaska and New Zealand: Liege, Belgium, Universitè de Liège, Ph.D. dissertation, 210 p.

Smith, T.N., 1995, Coalbed methane potential for Alaska and drilling results for the upper Cook Inlet Basin: Intergas, May 15-19, 1995, Tuscaloosa, University of Alabama, p. $1-21$.

Spicer, R.A., 1987, Late Cretaceous floras and terrestrial environment of northern Alaska, in Tailleur, I.L., and Weimer, Paul, eds., Alaskan North Slope geology: Society of Economic Paleontologists and Mineralogists and Alaska Geological Society Book 50, p. 497-512.

Stach, Erich, 1968, Basic principles of coal petrology-Macerals, microlithotypes, and some effects of coalification, in Murchison, D.G., and Westoll, T.S., eds., Coal and coalbearing strata: New York, Elsevier, p. 3-17.

Stach, Erich, Mackowsky, M.-Th., Teichmüeller, Marlies, Taylor, G.H., Chandra, D., and Teichmüeller, Rolf, 1982, Stach's textbook of coal petrology (3rd ed.): Berlin, Gebrüder Borntraeger, $535 \mathrm{p}$.

Stanley, R.G., Flores, R.M., and Wiley, T.J., 1992, Fluvial facies architecture in the Tertiary Usibelli Group of Suntrana, central Alaska, in Bradley, D.C., and Ford, A.B., eds., Geologic studies in Alaska by the U.S. Geological Survey, 1990: U.S. Geological Survey Bulletin, 1999, p. 204-211.

Stanton, R.W., Moore, T.A., Warwick, P.D., Crowley, S.S., and Flores, R.M., 1989, Comparative facies formation in selected coal beds of the Powder River Basin: 28th International Congress Field Trip Guidebook T132, p. 19-27.

State of Alaska, 1993, Alaska's high rank coals: Alaska Division of Geological and Geophysical Surveys, Information Circular 33, $36 \mathrm{p}$.

Stevens, C.C., 1971, A provenance study of the Tertiary sandstones in the Healy and Lignite Creeks coal basins: Fairbanks, University of Alaska, Master's thesis, 122 p. 
Stone, R.W., 1906, Coal fields of the Kachemak Bay region: U.S. Geological Survey Bulletin 277, p. 53-73.

Stricker, G.D., 1983, Coal occurrence, quality, and resource assessment, National Petroleum Reserve in Alaska, in U.S. Geological Survey polar research symposium-Abstracts with program: U.S. Geological Survey Circular 911, p. 32-33.

Stricker, G.D., 1991, Economic Alaskan coal deposits, in Gluskoter, H.J., Rice, D.D., and Taylor, R.B., eds., Economic geology, U.S.: Boulder, Colorado, Geological Society of America, The geology of North America, v. P-2, p. 591-602.

Stricker, G.D., and Flores, R.M., 1996, Miocene fluvial-tidal sedimentation in a residual forearc basin of the northeast Pacific Rim-Cook Inlet, Alaska case study: American Association of Petroleum Geologists Annual Convention, Abstracts with Program, San Diego, Calif., p. A-135.

Stricker, G.D., Flores, R.M., and Ochs, A.M., 2001, The draining of coalbed methane by surface mining in eastern Powder River Basin, Wyoming [abs]: 2001 International Coalbed Methane Symposium, May 14-18, 2001, Tuscaloosa, Alabama, 1 p.

Swenson, R.F., 1997, Introduction to Tertiary tectonics and sedimentation in the Cook Inlet Basin, in Karl, S.M., Vaughn, N.R., and Ryherd, T.J., eds., 1997 Guide to the geology of the Kenai Peninsula, Alaska: Anchorage, Alaska Geological Society, p. 18-27.

Szumigala, D.J., and Swainbank, R.C., 2001, Alaska's mineral industry 2000-A summary: Alaska Division of Geological and Geophysical Surveys Information Circular 47, 14 p.

Tailleur, I.L., 1965, Low-volatile bituminous coal of Mississippian age on the Lisburne Peninsula, northwestern Alaska: U.S. Geological Survey Professional Paper 525-B, p. B34-B38.

Tailleur, I.L., and Brosgé, W.P., 1976, Coal resources of northern Alaska may be nation's largest, in Rao, P.D., and Wolff, E.N., eds., Focus on Alaska's coal '75 (conference proceedings, University of Alaska, Fairbanks, October 15-17, 1975): University of Alaska Mineral Industries Research Laboratory Report no. 37, p. 219-226.

Teichmüeller, Marlies, and Teichmüeller, Rolf, 1968, Geological aspects of coal metamorphism, in Murchison, D.G., and Westoll, T.S., eds., Coal and coal-bearing strata: New York, Elsevier, p. 233-267.

Triplehorn, D.M., Turner, D.L., and Naeser, C.W., 1984, Radiometric age of the Chickaloon Formation of south-central Alaska-Location of the Paleocene-Eocene boundary: Geological Society of America Bulletin, v. 95, p. 740-742.
Tyler, Roger, Scott, A.R., and Clough, J.G., 2000, Coalbed methane potential and exploration targets for rural Alaska communities: Alaska Division of Geological and Geophysical Surveys, Preliminary Interpretive Report 2000-2, 169 p.

Usibelli, J.E., 1986, Coal transportation from pit to railcar at the Usibelli coal mine, in Rao, P.D., ed., Focus on Alaska's coal '86, proceedings of the conference: Fairbanks, University of Alaska Mineral Industry Research Laboratory Report No. 72, p. 53-58.

Wahrhaftig, Clyde, 1944, Coal deposits of the Costello Creek Basin, Alaska: U.S. Geological Survey Open-File Report 8, $8 \mathrm{p}$.

Wahrhaftig, Clyde, 1965, Physiographic divisions of Alaska: U.S. Geological Survey Professional Paper 482, 52 p., 6 plates.

Wahrhaftig, Clyde, 1970, Late Cenozoic orogeny in the Alaska Range: Geological Society of America Abstracts with Programs, v. 7, p. 713-714.

Wahrhaftig, Clyde, 1973, Coal reserves of the Healy Creek and Lignite Creek coal basins, Nenana coal field, Alaska: U.S. Geological Survey Open-File Report 73-355, 6 p., 28 sheets.

Wahrhaftig, Clyde, 1987, The Cenozoic section at Suntrana, Alaska, in Hill, M.L., ed., Cordilleran section of the Geological Society of America: Boulder, Colo., Geological Society of America, Centennial Field Guide, v. 1, p. 445-450.

Wahrhaftig, Clyde, Bartsch-Winkler, Susan, and Stricker, G.D., 1994, Coal in Alaska, in Plafker, George, and Berg, H.C., eds., The geology of Alaska: Geological Society of America, The geology of North America, v. G-1, p. 937-978.

Wahrhaftig, Clyde, and Hickcox, C.A., 1955, Geology and coal deposits, Jarvis Creek coal field, Alaska: U.S. Geological Survey Bulletin 989-G, p. 353-367, plates 10-12.

Wahrhaftig, Clyde, Wolfe, J.A., Leopold, E.B., and Lanphere, M.A., 1969, The coal-bearing group in the Nenana coal field, Alaska: U.S. Geological Survey Bulletin 1274-D, p. DI-D30.

Waring, G.A., 1936, Geology of the Anthracite Ridge coal district, Alaska: U.S. Geological Survey Bulletin 861, 57 p., 14 plates.

Wolfe, J.A., Hopkins, D.M., and Leopold, E.B., 1966, Tertiary stratigraphy and paleobotany of the Cook Inlet region, Alaska: U.S. Geological Survey Professional Paper 398-A, A1-A29. 
Wolfe, J.A., and Tanai, Toshimasa, 1980, The Miocene Seldovia Point flora from the Kenai Group, Alaska: U.S. Geological Survey Professional Paper 1105, 52 p., 25 plates.

Wolfe, J.A., and Tanai, Toshimasa, 1987, Systematics, phylogeny, and distribution of Acer (maples) in the Cenozoic of western North America: Journal of the Faculty of Science of Hokkaido University, ser. 4, v. 22, p. 1-246.

Wood, G.H., Jr., and Bour, W.V., III, 1988, Coal map of North America: U.S. Geological Survey Special Geologic Map, scale 1:5,000,000.

Wood, G.H., Jr., Kehn, T.M., Carter, M.D., and Culbertson, W.C., 1983, Coal resource classification system of the U.S. Geological Survey: U.S. Geological Survey Circular 891, $65 \mathrm{p}$. 


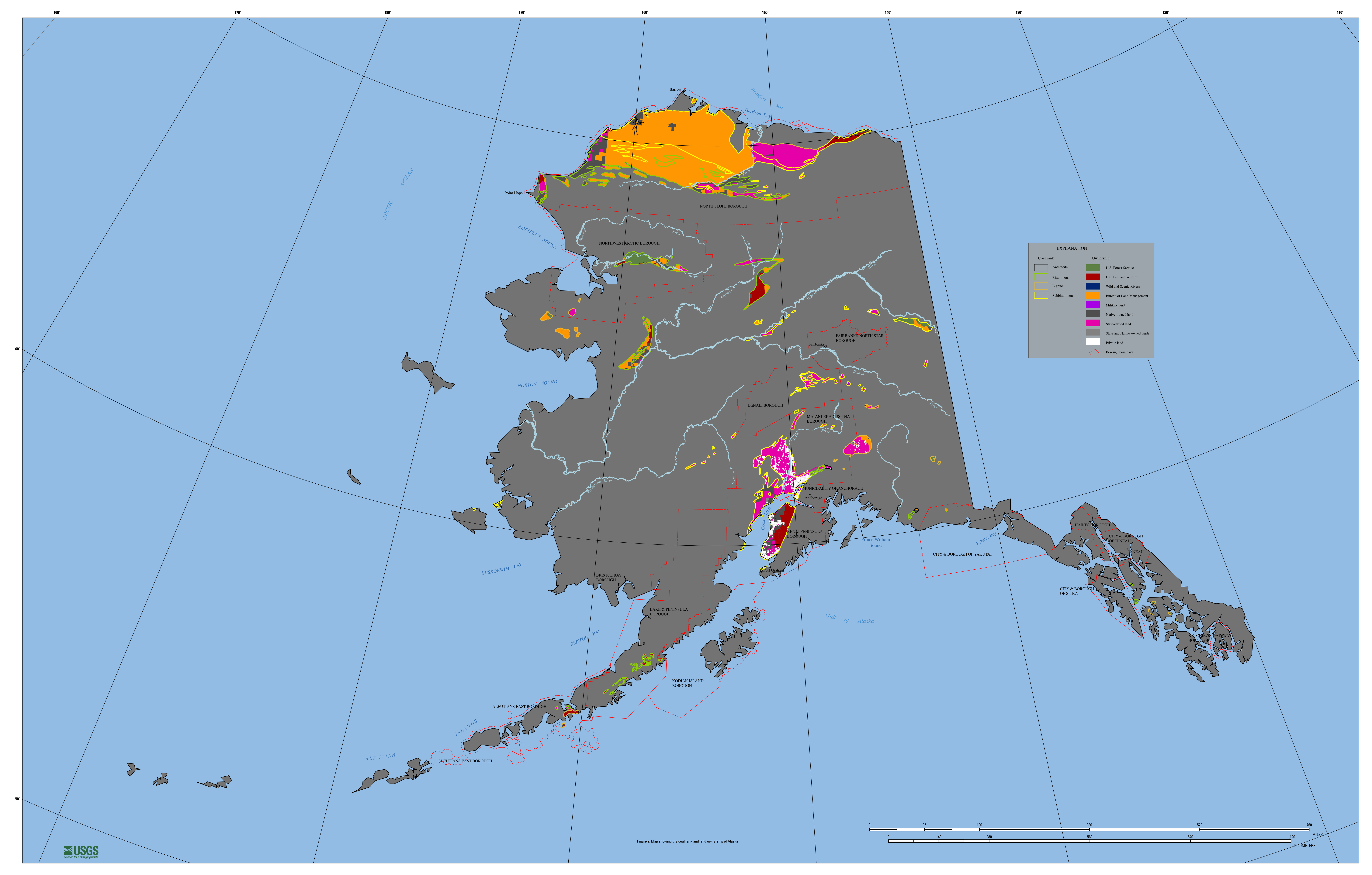



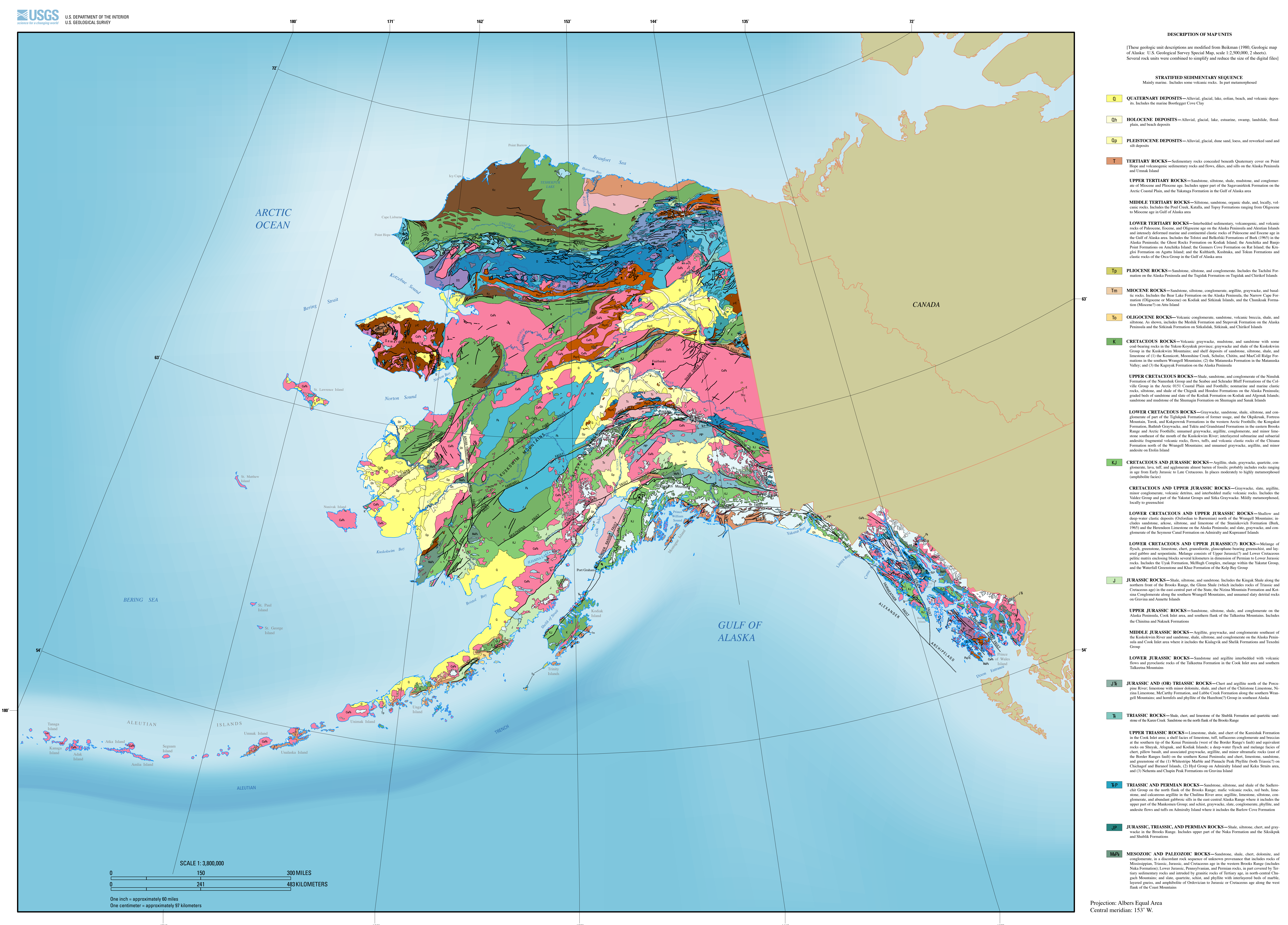

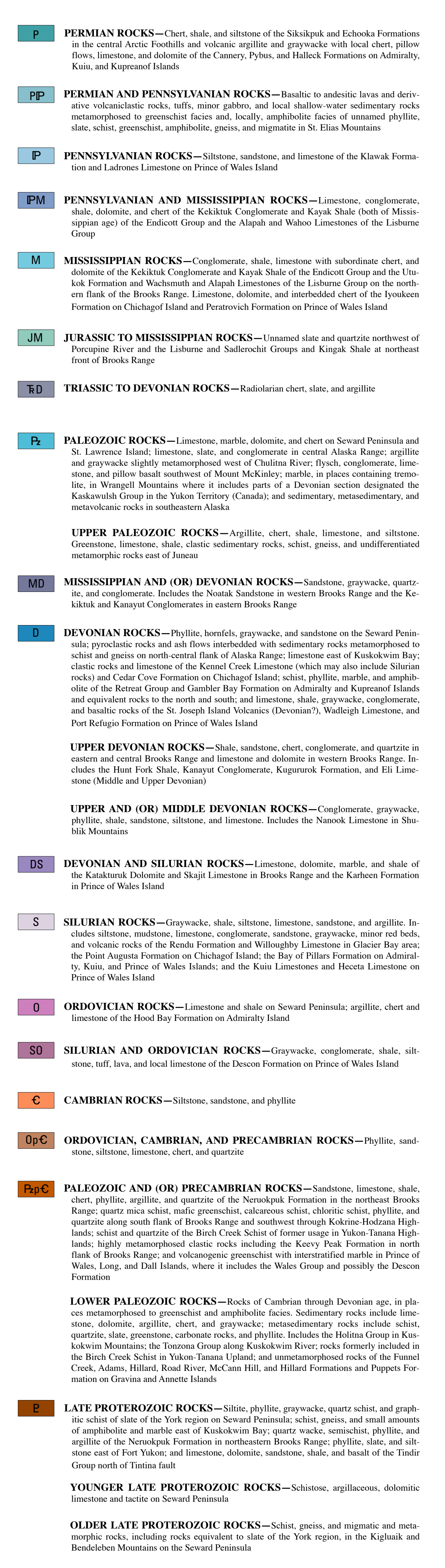

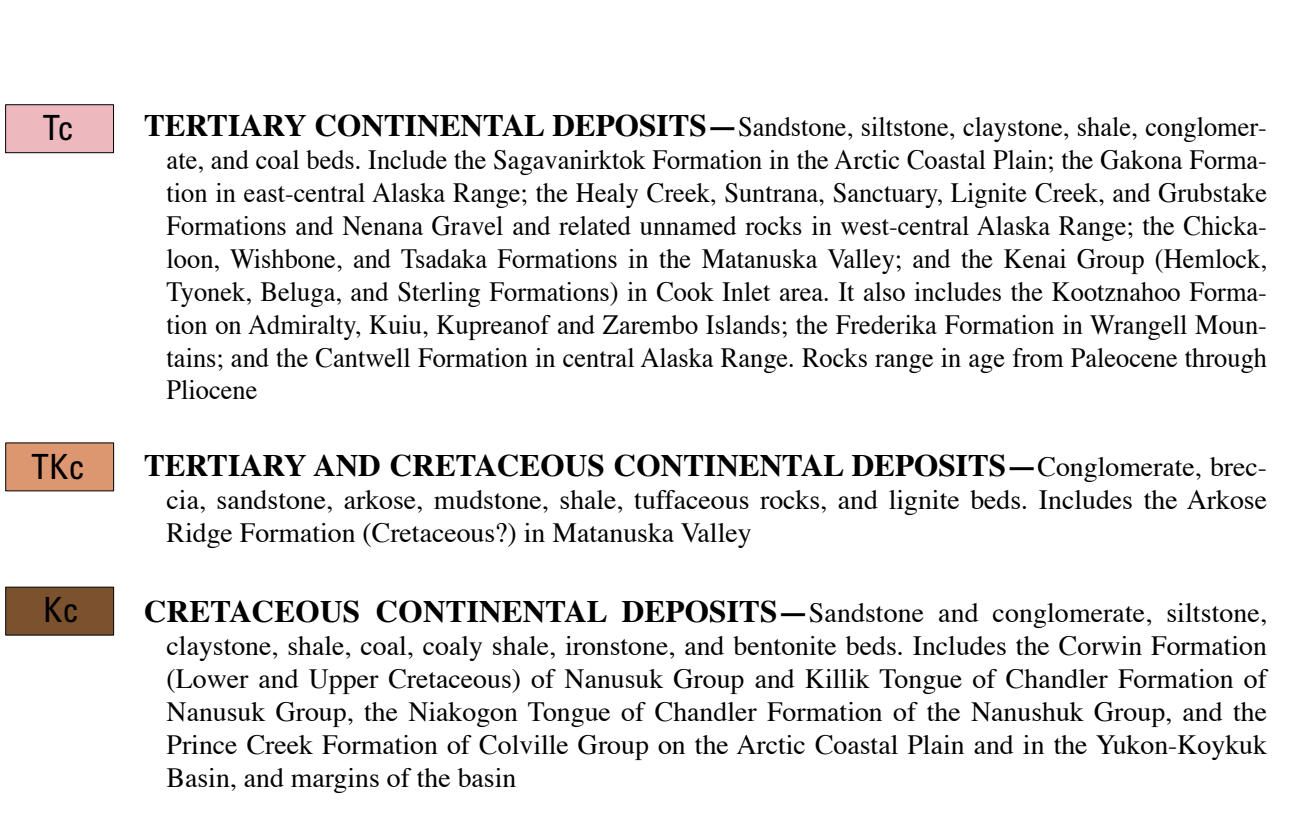

$=$

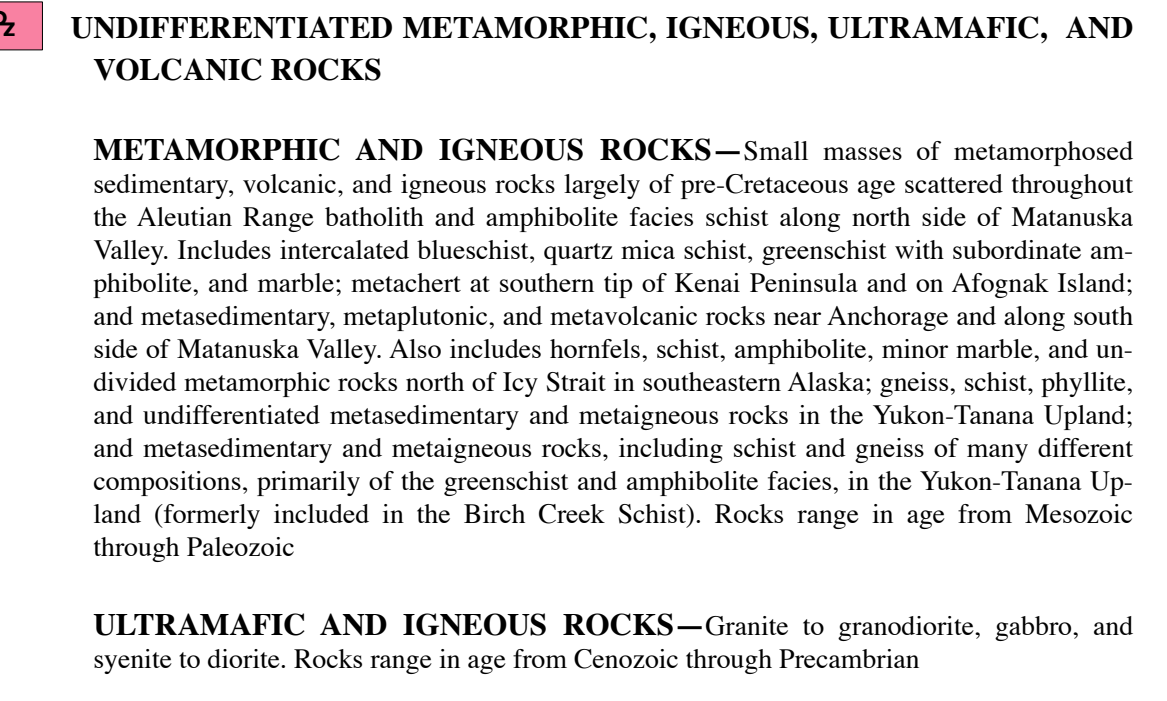

mans

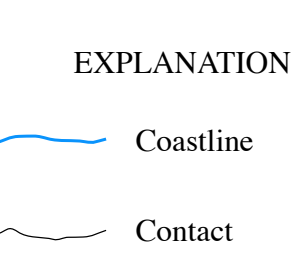

$\square^{\text {rat }}$

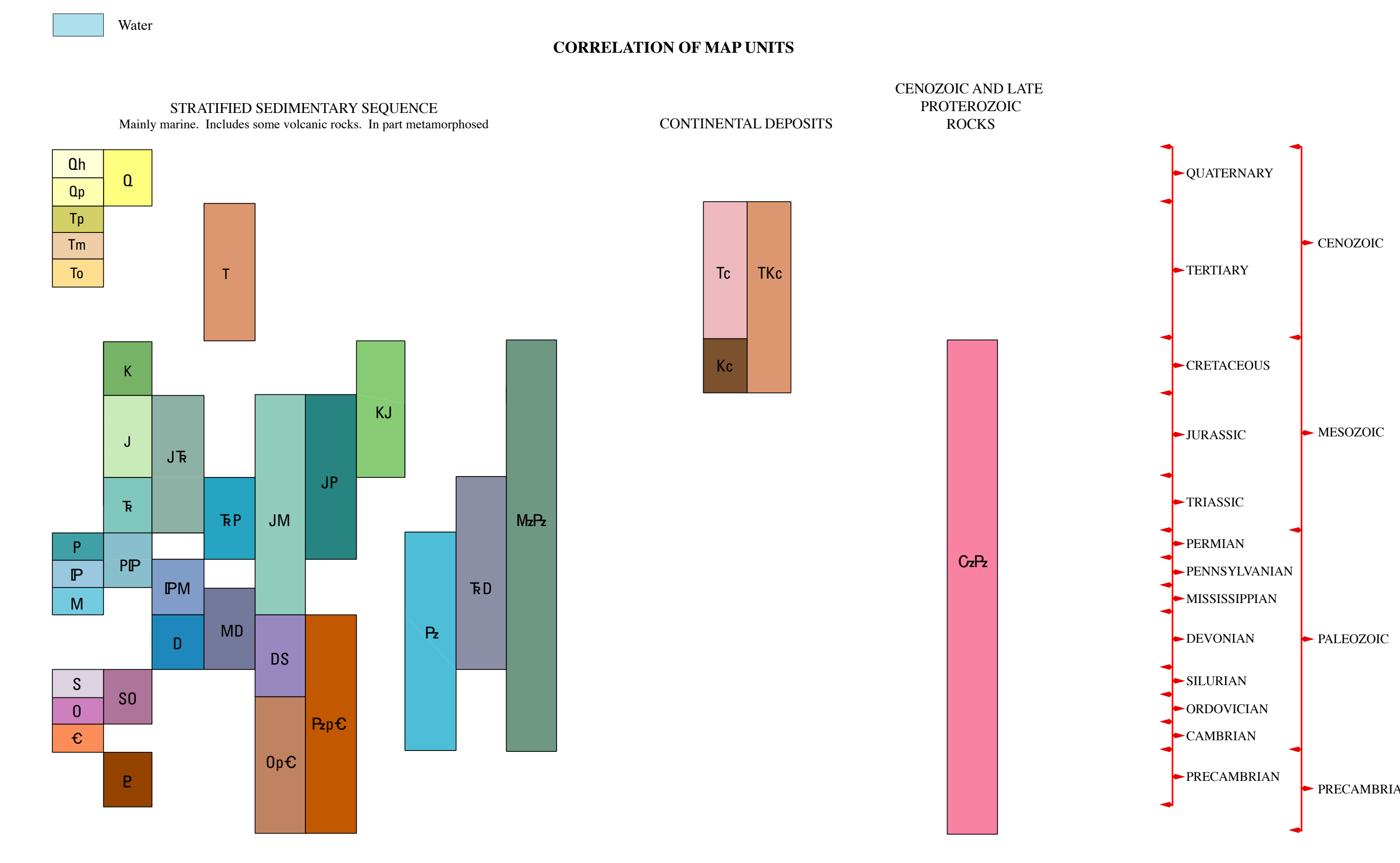

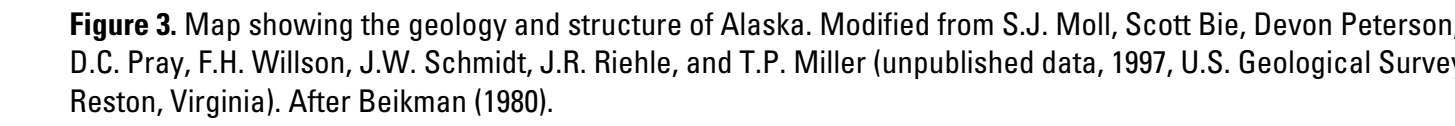
$+2$ 
